


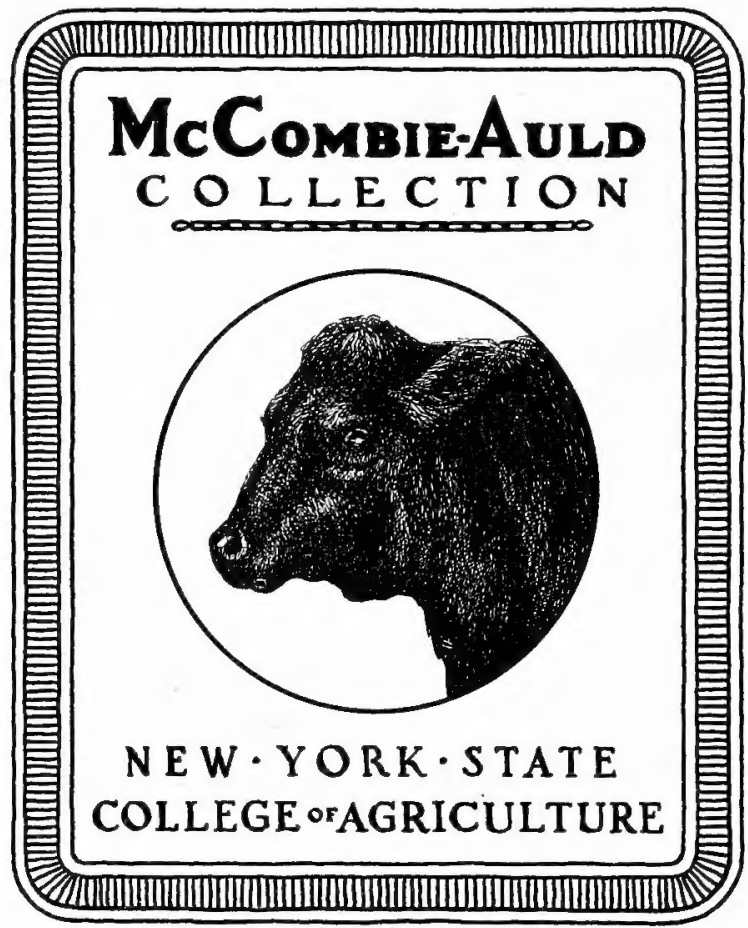




\section{Date Due}

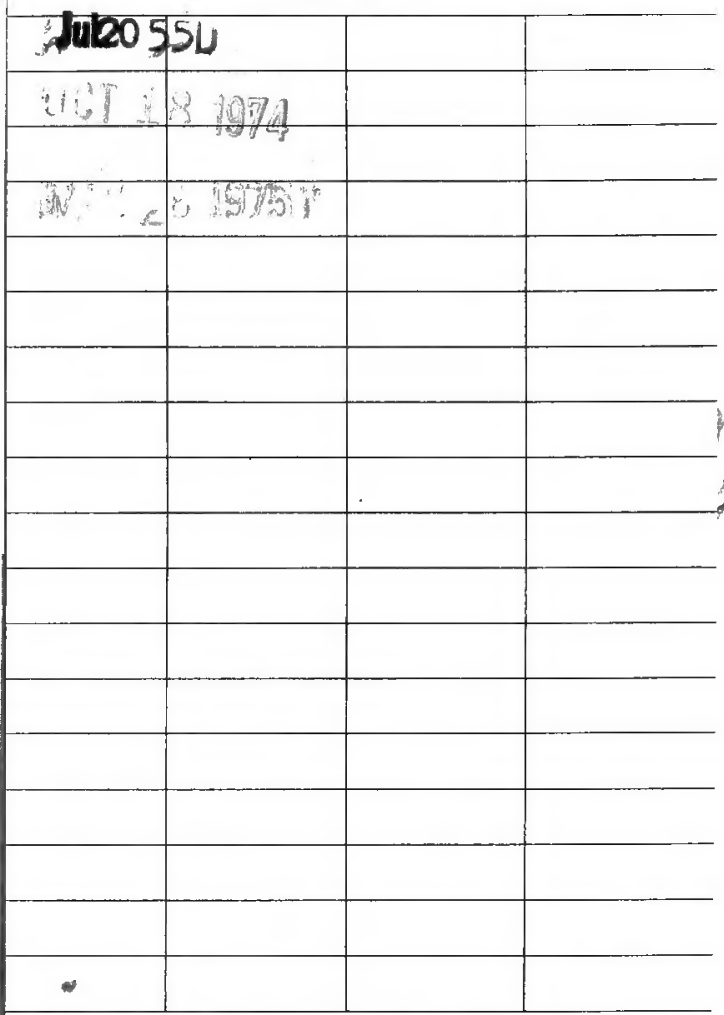

Library Bureau Cat. No. 1137

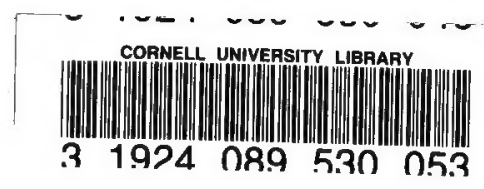


C
$Q 1$
$F$
19 


\section{Cornell University Library}

The original of this book is in the Cornell University Library.

There are no known copyright restrictions in the United States on the use of the text.

http://www.archive.org/details/cu31924089530053 

ANIMAL ACTIVITIES 



\title{
ANIMAL ACTIVITIES
}

A FIRST BOOK IN ZOÖLOGY

\author{
$\mathbf{B Y}$ \\ NATHANIEL S. FRENCH, PH.D.
}

Teacher of Zoblogy in the Roxbury High School

Boston, Mass.

\section{Wuitb Nlustrations}

NEW IMPRESSION

L ONGMANS, GREEN; AND CO. 9I AND 93 FIFTH AVENUE, NEW YORK LONDON AND BOMBAY $x 905$ 


$$
\begin{aligned}
& \text { G } 448 \\
& F 87 \\
& 1905
\end{aligned}
$$

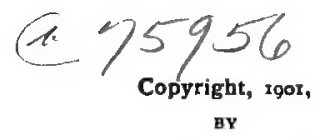

LONGMANS, GREEN, AND CO.

First Edition, March, rgoz;

Reprinted, January, 1903.

Reprinted, August, rgo5. 


\section{INTRODUCTION.}

THE book here presented is the outgrowth of fifteen years of teaching the subject to large classes in a high school. Its aim is to interest and guide pupils in the study of living animals. Young people are usually ready to be made acquainted with their immediate neighbors in the animal world, and it is hoped that this book may be of assistance to them.

In the choice and arrangement of topics the powers and interests of young students have been kept in view rather than the demands of strictly logical description and exposition. Chapter I outlines the animal kingdom in such a manner as to be useful for reference purposes. Chapter II gives directions for assisting the student in procuring his own specimens for study. Chapter III describes the activities common to all animals. With Chapter IV work on the Arthropoda begins. Animals of this group are selected for the early part of the work because living specimens can be easily collected and observed in the fall, at which time Zoölogy is begun in most schools. After the study of the Arthropoda, the book follows the natural order, beginning with the simplest animals and ending with the most complex. In some schools it will doubtless be better to begin with Chapter XI, and study the Arthropoda directly after the chapter on "The Earthworm". This latter order of subjects is advised when the Zoölogy course begins in the winter or spring.

Throughout the book adaptation to environment is constantly pointed out. Much is made of habitat in 
connection with the manner in which an animal performs its life-functions.

The directions for laboratory work are mainly in the form of questions which must be answered from direct observation. Comparisons and inferences are constantly required of the pupil. The exercises for review of note-book work enable pupils to systematize their knowledge. Useful vocabularies are frequently inserted.

For many valuable suggestions the author is indebted to Miss Helen A. Gardner and Miss Mary E. Winn of the Girls' High School, Boston, and Prof. B. H. Van Vleck of Boston University, who read the manuscript; and to Mr. Frank M. Whitney, principal of the Watertown, Mass., High School and Miss E. O. Patch of the Girls' High School, Boston, who examined the proof-sheets. Mr. Lyman G. Smith of the Roxbury High School and Mr. Arthur E. Sanford assisted in preparing some of the drawings, and many of the illustrations have been reproduced, by permission, from Agassiz's "Seaside Studies " (Houghton, Mifflin, \& Co.), "The Horse” by W. H. Flower (D. Appleton \& Co.), various works published by Longmans, Green, \& Co., and other sources.

\section{A LIST OF BOOKS.}

All the books on the list given below have been found useful to pupils, and nearly all of them have been reported as "interesting " by many pupils who have read them. Such books may be used to advantage in the preparation of Reports. The list was first printed by a branch of the Agassiz Society connected with the Roxbury High School of Boston, Mass.

Abbott, Charles Conrad:

A Naturalist's Rambles about Home.

Bird Land Echoes. Illustrated.

Agassiz, Elizabeth and Alexander:

Seaside Studies in Natural History. Illustrated. 
Allen, Grant:

Flashlights on Nature. Illustrated.

Apgar, Austin C.:

Birds of the United States. Illustrated.

BADENOCH, L. N. :

Romance of the Insect World. Illustrated.

BaUsCh, EDward:

Manipulation of the Microscope.

Bateman, G. C. :

The Vivarium. Illustrated.

Beard, James Carter:

Curious Homes and their Tenants. Illustrated.

Beddard, Frank E. :

Elementary Practical Zoölogy.

A Text-book of Zoögeography.

Bolles, Frank:

At the North of Bearcamp Water.

Brooks, W. K. :

The Oyster. Illustrated.

Buckley, Arabella B. :

Life and her Children. Illustrated.

The Winners in Life's Race. Illustrated.

Burroughs, John:

Birds and Bees and Sharp Eyes.

Riverby.

Wake Robin.

Locusts and Wild Honey.

Carrington, Edith:

Animals' Ways and Claims. Illustrated.

ChapMan, Frank M.:

Bird Life. Illustrated.

Chatty Readings in Elementary Science (Longmans):

Nature Knowledge, Books I, II, III. Illustrated.

Cornish, C. J. :

Animals of To-day. Illustrated.

Animals at Work and Play. Illustrated.

Wild Animals in Captivity. Illustrated. 
Corey, C. B. :

How to Know the Shore Birds. Illustrated.

Darwin, Charles R. :

What Mr. Darwin saw in his Voyage Round the World in the Ship "Beagle". Illustrated.

The Formation of Vegetable Mould. Illustrated.

Davie, Oliver:

Nests and Eggs of North American Birds. Illustrated.

De Kay, Charles :

Bird Gods. Illustrated.

Dixon, Charles:

Curiosities in Bird Life.

Doubleday, N. B. DeG. :

Birds that Hunt and are Hunted. Illustrated.

Bird Neighbors. Illustrated.

Duncan, P. Martin:

The Transformation of Insects. Illustrated.

Davenport, C. B. and G. C.:

Introduction to Zoölogy. Illustrated.

Edwards, Clarence E. :

The Campfires of a Naturalist. Illustrated.

Emerton, J. H. :

The Structure and Habits of Spiders. Illustrated.

Figuier, Guillaume Louis:

The Ocean World. Illustrated.

The Insect World. Illustrated.

Flower, William Henry:

The Horse. Illustrated.

Forbes, EDward:

A History of British Starfishes. Illustrated.

French, G. H. :

The Butterflies of the Eastern United States.

Furneaux, W. :

The Out-door World. Illustrated.

Life in Ponds and Streams. Illustrated.

Graham, P. Anderson:

Country Pastimes for Boys. Illustrated.

Holland, W. J.:

The Butterfly Book. Illustrated. 
JORDAN and KELLOGG :

Animal Life. Illustrated.

KEARTON, R.:

Wild Life at Home. How to Study and Photograph it. Illustrated.

Kingsley, John Sterling:

The Riverside Natural History, five volumes. Illustrated.

LOVELL, M. S. :

Edible Mollusks of Great Britain.

Luвbоск, Sir John :

On the Origin and Metamorphosis of Insects.

The Beauties of Nature and Wonders of the World.

Ants, Bees, and Wasps. Illustrated.

Mangin, Arthur:

The Mysteries of the Ocean. Illustrated.

Manton, Walter P.:

Taxidermy without a Teacher.

Insects, How to Catch and Prepare.

Mathews, F. Schuyler:

Familiar Life in Field and Forest. Illustrated.

McCook, Henry C. :

The Honey Ants of the Garden of the Gods. Illustrated. Merriam, Florence A. :

Birds of Field and Village. Illustrated.

Birds Through an Opera Glass. Illustrated.

Merriam, C. Hart :

Mammals of the Adirondack Region.

Miall, Louis Compton:

The Natural History of Aquatic Insects. Illustrated.

Round the Year. Illustrated.

Michelet, Jules:

The Insect. Illustrated.

The Bird. Illustrated.

Miller, Olive Thorne:

Little Brothers of the Air.

Four-handed Folk. Illustrated.

Bird Ways.

In Nesting Time.

Little Folks in Feathers and Fur. Illustruted. 
Morgan, C. L. :

Animal Sketches. Illustrated.

Needham, James G. :

Outdoor Studies. Illustrated.

Nehrling, Henry:

Native Birds of Song and Beauty. Illustrated, two volumes.

Oswald, Felix L. :

Zoölogical Sketches. Illustrated.

PACKard, A. S. :

A Guide to the Study of Insects. Illustrated.

Parkhurst, H. E. :

The Birds' Calendar. Illustrated.

Porter, J. Hampden :

Wild Beasts. Illustrated.

RusS, KARL:

The Speaking Parrots. Illustrated.

Scudder, Samuel H. :

The Life of a Butterfly. Illustrated.

Butterflies: Structure, Changes, and Life-histories.

Semper, Frank W. :

Injurious Insects, and Use of Insecticides. Illustrated.

Shaler, Nathaniel S. :

Domesticated Animals. Illustrated.

Simmonds, P. L. :

Commercial Products of the Sea. Illustrated.

Stokes, A. C. :

Microscope for Beginners.

Thomson, William:

Great Cats I Have Known. Illustrated.

Thompson, ERnest Seton:

Wild Animals I Have Known. Illustrated.

Torrey, BradFord:

Birds in the Bush.

Wallace, Alfred Russell:

Darwinism. Illustrated.

Weed, Clarence Moore:

Life-histories of American Insects. Illustrated. 
Wrlson, Sir Daniel:

Left-handedness.

WOOD, THEODORE :

The Farmers' Friends and Foes. Illustrated.

Wood, Rev. J. G. :

Homes Without Hands. Illustrated.

Wright, Mabel Osgood:

Four-footed Americans. Illustrated.

Bird Craft. Illustrated. 



\section{TABLE OF CONTENTS.}

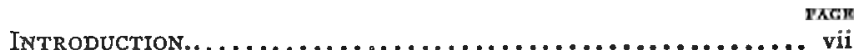

CHAPTER I.

AnImals Classified.......................... I

CHAPTER II.

MATERIAL for StUdy....................... 4

CHAPTER III.

Activities Common to All Animals.................. 24

CHAPTER IV.

Grasshoppers and Crickets...................... 32

CHAPTER V.

Butterfies and Moths with their Protective Devices... 45

CHAPTER VI.

Some Insects Classified....................... 57

CHAPTER VII.

A Chapter of Life-Histories.................... 68 
CIIAPTER VIII.

Some InSECt Adaptations.................... 86

\section{CHAPTER IX.}

A Spider's Activities.......................... 93

CHAPTER $\mathrm{X}$.

Homologies among Crustacea................... ioi

CHAPTER XI.

The Activities of One-Celled Animals and Sponges....... i16 CHAPTER XII.

The Hydra and Some Celenterates which Live in Colonies 128 CHAPTER XIII.

The Starfish and Closely Related Animals.......... r 40 CHAPTER XIV.

The Earthworm and His Work................ 148 CHAPTER XV.

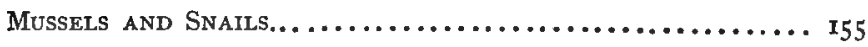

CHAPTER XVI.

The Structure and Activities of A Fish............ 169 CHAPTER XVII.

TADPOLES AND Frogs. $\ldots \ldots \ldots \ldots \ldots \ldots \ldots \ldots \ldots \ldots \ldots \ldots$ 
TABLE OF CONTENTS.

CHAPTER XVIII.

page

Birvs.................................. ref

CHAPTER XIX.

Man's Near Relatrive....................... 2II

CHAPTER $\mathrm{XX}$.

The Distribution of Animals.................. 236

CHAP'TER XXI.

Animal Relationships.......................... 243 



\section{LIST OF ILLUSTRATIONS.}

NoTr. - The fgures in brackets [ $\mathrm{T}]$ following the titles refer to the list, printed below, of books from which the
illustrations are, by permission, respectively borrowed.

rig.

PAGE

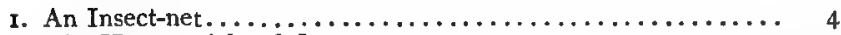

2. The House-cricket $[\mathrm{r}] \ldots \ldots \ldots \ldots \ldots \ldots \ldots \ldots \ldots \ldots \ldots \ldots \ldots$

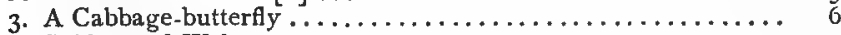

4. Spider and Web.......................... 7

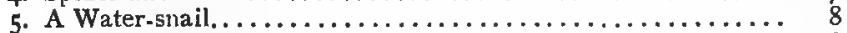

6. Shell of a Fresh-water Mussel $[2] \ldots \ldots \ldots \ldots \ldots \ldots \ldots \ldots \ldots . \ldots \ldots$

7. An American Pondweed....................... 9

8. The Hornwort ........................... 9

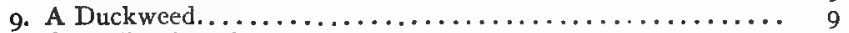

Io. Other Pondweeds.......................... Io

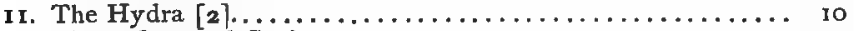

12. Water-fieas and Cyclops....................... I I

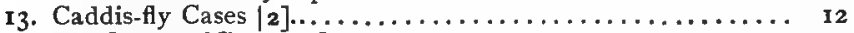

14. The Larva of Dragon-fly..................... I2

15. Larva of Dyticus........................ I2

16. Larva of Whirligig Beetle.................. I2

17. Larva of a May-fly ........................ Iz

18. Side View of Crayfish $[5] \ldots \ldots \ldots \ldots \ldots \ldots \ldots \ldots \ldots \ldots \ldots$

19. A Campanularian Hydroid Colony [6] .............. 14

20. A Sertularian Colony $[6] \ldots \ldots \ldots \ldots \ldots \ldots \ldots \ldots \ldots \ldots \ldots \ldots \ldots$

2 I. A Net for Collecting at the Seaside................. 15

22. Sea-anemones.......................... I6

23. A Starfish $[6] \ldots \ldots \ldots \ldots \ldots \ldots \ldots \ldots \ldots \ldots \ldots \ldots \ldots \ldots \ldots$ I

24. A Sea-urchin......................... I7

25. A Sea-cucumber......................... 18

26. A Hermit-crab.......................... I8

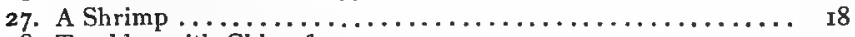

28. Tumbler with Chloroform ..................... I9

29. A Cockroach $[\mathbf{r}] \ldots \ldots \ldots \ldots \ldots \ldots \ldots \ldots \ldots \ldots \ldots \ldots$ 20

30. Mourning-cloak Butterfly..................... 2 I

31. A Wasp's Nest [3]........................... 22

32. Cocoon of Cecropia . ...................... 22

33. Eggs of Frog Just Laid [2] ..................... 23

34. Eggs of Frog a Few Hours After Laying [2] ............ 23

35 Apparatus for Decomposing Water.................. 26

36. Apparatus for Removing Oxygen from Air.............. 28

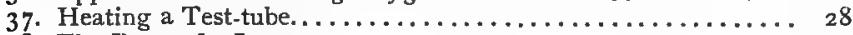

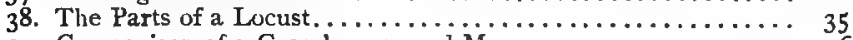

39. Comparison of a Grasshopper and Man............... $3^{6}$ 
FIG.

40. The Trachea of an Insect $[2] \ldots \ldots \ldots \ldots \ldots \ldots 3^{8}$

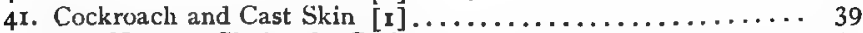

42. The Nervous Chain of a Cockroach $[1] \ldots . \ldots \ldots \ldots \ldots \ldots . . . . .40$

43. Portion of the Cornea of a Fly's Compound Eye [1]....... 4I

44. The Hearing Organ of a Cricket $[\mathrm{I}] \ldots \ldots \ldots \ldots \ldots \ldots \ldots$. . . . .

45. The Stridulating Organ of a Cricket $[x] \ldots \ldots \ldots \ldots \ldots \ldots \ldots$

46. Antennae of Lepidoptera $[4] \ldots \ldots \ldots \ldots \ldots \ldots \ldots \ldots \ldots \ldots \ldots \ldots$

47. Eggs of Lepidoptera [4] . . . . . . . . . . . . . . . . . . 47

48. Some Larvæ of Lepidoptera... . . . . . . . . . . . . . . . . 48

49. Some Cocoons and Chry salids $[4] \ldots \ldots \ldots \ldots \ldots \ldots \ldots \ldots \ldots . \ldots \ldots$

50. A Cabbage-butterfly ........................ 49

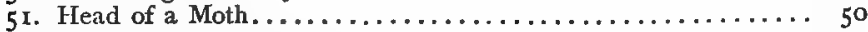

52. The Kallima.............................. $5^{\text {I }}$

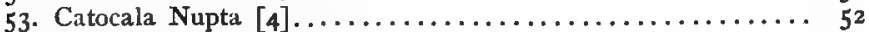

54. The Milkweed-butterfly....................... 53

55. Limenitis Ursula . . . . . . . . . . . . . . . . . . . 53

$56 a$. Moth at Rest. .......................... 55

$56 b$. Butterfly at Rest............................. 55

57. Larva and Pupa of the House-fly $[1] \ldots \ldots \ldots \ldots \ldots \ldots . \ldots . \ldots$

58. Right Winglet of Bluebottle $[\mathbf{r}] \ldots \ldots \ldots \ldots \ldots \ldots \ldots \ldots \ldots \ldots$

59. Balancer of Bluebottle $[\mathrm{I}] \ldots \ldots \ldots \ldots \ldots \ldots \ldots \ldots \ldots \ldots \ldots \ldots \ldots \ldots$

6o. Portion of a Fly's Foot $[1] \ldots \ldots \ldots \ldots \ldots \ldots \ldots \ldots \ldots \ldots$

6r. Side View of Proboscis, partly opened [I]............ 59

62. Head of Bluebottle $[\mathbf{I}] \ldots \ldots \ldots \ldots \ldots \ldots \ldots \ldots \ldots \ldots \ldots$

63. Eggs of Milkweed-butterfly ................... 68

64. Larva of Milkweed-butterfly..................... 69

65. Pupa of Milkweed-butterfly ...................... 69

66. Female and Male Aphis.................... 7 I

67. A Microgaster Fly.......................... 75

68. The Dragon-fly $[2] \ldots \ldots \ldots \ldots \ldots \ldots \ldots \ldots \ldots \ldots \ldots \ldots \ldots \ldots$

69. The Imago of a Dragon-fly $[2] \ldots \ldots \ldots \ldots \ldots \ldots \ldots \ldots . \ldots . \ldots . \ldots$

70. Caddis-fly, Adult and Larval Cases [2]............ 79

71. The Growth of a May-fly [2] .................. 80

72. A Water-boatman........................... 8I

73. Dyticus Marginalis ........................ 8 I

74. Mouth of a Bug .......................... 82

75. The Egg-raft of a Mosquito $[3] \ldots \ldots \ldots \ldots \ldots \ldots \ldots \ldots \ldots$

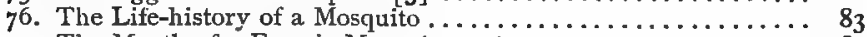

77. The Mouth of a Female Mosquito $[2] \ldots \ldots \ldots \ldots \ldots \ldots \ldots$

78. The Leg of a Cockroach $[\mathrm{r}] \ldots \ldots \ldots \ldots \ldots \ldots \ldots \ldots \ldots \ldots \ldots$

79. A Mole-cricket........................... 86

80. Fore Legs of a Water-bug $[2] \ldots \ldots \ldots \ldots \ldots \ldots \ldots \ldots \ldots \ldots . \ldots . \ldots . \ldots . \ldots$

81. Legs of Dyticus $[2] \ldots \ldots \ldots \ldots \ldots \ldots \ldots \ldots \ldots \ldots \ldots \ldots \ldots$

82. Fore Leg of a Butterfly $[4] \ldots \ldots \ldots \ldots \ldots \ldots \ldots \ldots \ldots$

83. Hive-bees.............................. go

84. Fertilization of a Flower by an Insect.................

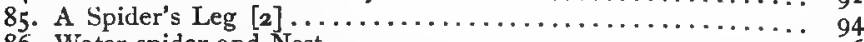

86. Water-spider and Nest. ...................... 96

87. Side View of Crayfish $[5] \ldots \ldots \ldots \ldots \ldots \ldots \ldots \ldots \ldots \ldots \ldots$ ror

88. Dorsal View of Crayfish $[5] \ldots \ldots \ldots \ldots \ldots \ldots \ldots \ldots \ldots \ldots \ldots \ldots$

89. Ventral View of Crayfish $[5] \ldots \ldots \ldots \ldots \ldots \ldots \ldots \ldots \ldots \ldots \ldots$ ro 
9o. Fourth Abdominal Segment of Crayfish [5]............. 104

91. Crayfish Appendages $[5] \ldots \ldots \ldots \ldots \ldots \ldots \ldots \ldots \ldots$. $\ldots \ldots \ldots$

92. Longitudinal Section of Crayfish $[5] \ldots \ldots \ldots \ldots \ldots \ldots \ldots . . \ldots 106$

93. Walking Appendage of Crayfish with Gill Attached [5].... IO7

94. The Common Crab .......................... 108

95. Early Stages of Shore-crab...................... I08

96. Water-flea $[2] \ldots \ldots \ldots \ldots \ldots \ldots \ldots \ldots \ldots \ldots \ldots \ldots$. . . . . . . . 9

97. Cyclops $[2] \ldots \ldots \ldots \ldots \ldots \ldots \ldots \ldots \ldots \ldots \ldots \ldots \ldots$. . . . . . . . . . .

98. A Barnacle................................. I

99. Forms of Amobæ......................... 117

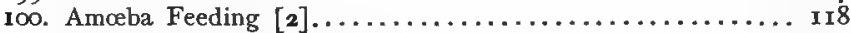

Ior. Amceba Dividing $[2] \ldots \ldots \ldots \ldots \ldots \ldots \ldots \ldots \ldots \ldots \ldots$. . . . . . . . .

I02. One of the Foraminifera................... I20

ro3. The Origin of Chalk. ...................... r2o

ro4. Infusorial Earth........................ 12 I

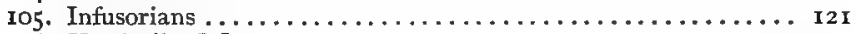

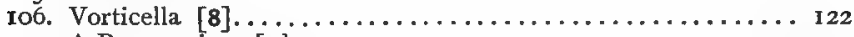

I07. A Paramecium $[5] \ldots \ldots \ldots \ldots \ldots \ldots \ldots \ldots \ldots \ldots \ldots \ldots \ldots \ldots$

108. Structure of a Sponge......................... I24

rog. Sponge Spicules $[2] \ldots \ldots \ldots \ldots \ldots \ldots \ldots \ldots \ldots \ldots \ldots \ldots \ldots$. . . . . . . . .

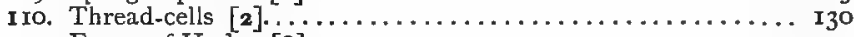

II1. Forms of Hydra [8] ....................... I 3 I

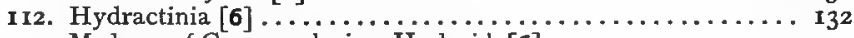

I 3. Medusæ of Campanularian Hydroid [6] ............ I 34

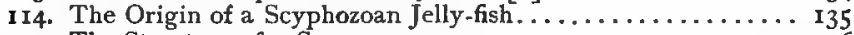

I 15. The Structure of a Sea-anemone................. I 36

I 16. A Starfish . . . . . . . . . . . . . . . . . . . . I42

I17. A Brittle Starfish........................... I44

I 8 . The Structure of a Sea-urchin. . . . . . . . . . . . I46

I r. A Sea-cucumber.......................... I46

I20. An Earthworm............................. I 49

I2 I. A Worm's Setæ.......................... I50

122. Worm-casts............................... I50

123. A Fresh-water Mussel Showing Position of Foot and Siphons. . I57

124. Fresh-water Mussel with One Valve Removed [5]......... I59

125. Digestive Tube of Fresh-water Mussel [5] . . . . . . . . . . . I60

126. Cross section of Anodon [5]................. I6I

127. Nervous System of Arodon [5]................. I6r

128. A Slug. .............................. I $6_{3}$

129. A Snail ............................... I6 5

130. A Squid................................. I 66

131. Part of a Lingual Ribbon...................... I66

132. The Circulation of Blood in a Fish............... I7

133. Internal Organs of Fish.................... 172

134. Skeleton of a Fish . . . . . . . . . . . . . . . . I 73

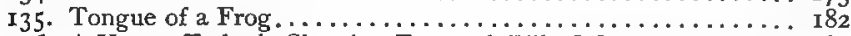

136. A Young Tadpole Showing External Gills $[2] \ldots \ldots \ldots \ldots \ldots . . . . .2$

137. Under Side of Tadpole Showing Coiled Intestine and Internal

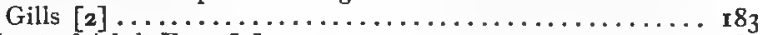

138. Heart of Adult Frog $[2] \ldots \ldots \ldots \ldots \ldots \ldots \ldots \ldots \ldots \ldots \ldots \ldots$

r39. Blood-cells of a Frog $[9] \ldots \ldots \ldots \ldots \ldots \ldots \ldots \ldots \ldots \ldots \ldots$ 
FIG.

140. Blood-corpuscles of Man $[9] \ldots \ldots \ldots \ldots \ldots \ldots \ldots \ldots \ldots$. 84

I4I. Viscera of Frog............................ I85

142. Digestive Organs of Man [9]................... 186

143. Growth of Frog's Lung from Primitive Fuod-tube.......... I87

144. Growth of Frog's Egg [2] ................. I88

145. Very Young Tadpoles $[2] \ldots \ldots \ldots \ldots \ldots \ldots \ldots \ldots \ldots \ldots \ldots$. 83

r46. Various Stages of Tadpole $[2] \ldots \ldots \ldots \ldots \ldots \ldots \ldots \ldots \ldots$. . . . . . . . . .

147. Young Frogs $[2] \ldots \ldots \ldots \ldots \ldots \ldots \ldots \ldots \ldots \ldots \ldots \ldots \ldots$. . . . . . . . . .

148. The Use of a Muscle......................... Igo

149. Striped Muscle-fibres $[9] \ldots \ldots \ldots \ldots \ldots \ldots \ldots \ldots \ldots$. . . . . . . .

I50. Unstriped Muscle fibres $[9] \ldots \ldots \ldots \ldots \ldots \ldots \ldots \ldots \ldots \ldots$. . . . . . .

I5 1. A Frog's Skeleton . . . . . . . . . . . . . . . . . . . . . 193

152. A Man's Skeleton. .............................. I94

I53. Brain of Frog. . . . . . . . . . . . . . . . . . . . I 94

154. Brain and Spinal Cord of Man. . . . . . . . . . . . I95

r55. Beaks of Various Birds. . . . . . . . . . . . . . . . . . . I 99

156. The Digestive Organs of a Bird.................. 200

557. Diagram of the Heart of a Bird $[3] \ldots \ldots \ldots \ldots \ldots \ldots$. . . . .

I58. The Skeleton of a Bird .................... 202

159. A Swallow Feeding Her Young................... 20.3

160. Arm of Man, Fore Leg of Dog, Wing of Bird. . . . . . . . . . 204

161. A Bird's Wing ........................... 204

162. The Sternum of a Shrike . . . . . . . . . . . . . . 205

163. Feathers. ........................... 206

164. A Bird's Leg. .............................. 207

165. Feet of Birds. . . . . . . . . . . . . . . . . . . 208

166. The Archæopteryx. ... . . . . . . . . . . . . . . . . . . 209

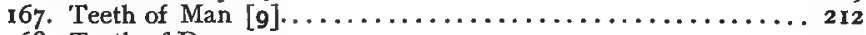

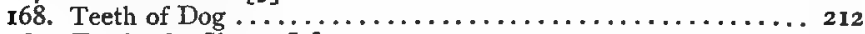

169. Teeth of a Sheep $[3] \ldots \ldots \ldots \ldots \ldots \ldots \ldots \ldots \ldots \ldots \ldots \ldots$

170. Teeth of Hare......................... 213

I7 r. Skull of Cow Showing Teeth.................... 2 I4

172. The Human Eye......................... 2 I4

173. Skeletons of Man and Horse $[10] \ldots \ldots \ldots \ldots \ldots \ldots \ldots \ldots \ldots$

174. Bones of $\operatorname{Leg}$ and Arm of $\operatorname{Man}[\mathrm{II}] \ldots \ldots \ldots \ldots \ldots \ldots \ldots \ldots$

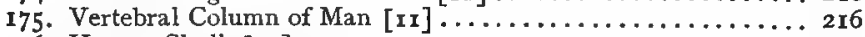

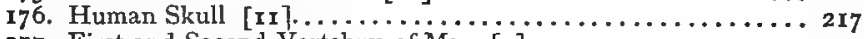

177. First and Second Vertebræ of Man [9] .............. 219

I78. Skeleton of Gorilla......................... 220

I79. Diagram Showing Circulation of Blood in Man [II] ...... 22 I

I80. Skeleton of Bat Showing Wings.................

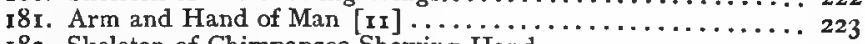

182. Skeleton of Chimpanzee Showing Hand.............. 223

I83. Fore Foot of Mole. . . . . . . . . . . . . . . . . . . 224

184 . Fore Foot of Cat. . . . . . . . . . . . . . . . . . . . 224

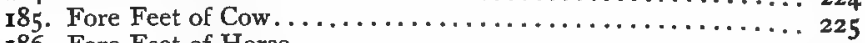

186. Fore Feet of Horse. . . . . . . . . . . . . . . . . 225

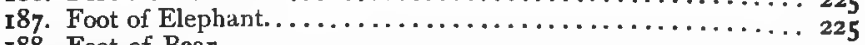

188. Feet of Bear . . . . . . . . . . . . . . . . . . . 225

189. Sole of Foot of Man, of Dog, and of Horse [10]......... 226

Igo. Finger of Man and of Horse $[10] \ldots \ldots \ldots \ldots \ldots \ldots \ldots \ldots \ldots . \ldots . \ldots 227$ 
19r. Feet of Ancestors of Horse . . . . . . . . . . . . 228

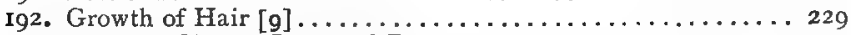

193. Horns of Sheep, Cow, and Deer.................. 230

194. Skull of Cow Showing the Bone of the Horn ........... 231

195. A Manlike Ape Walking..................... ${ }_{232}$

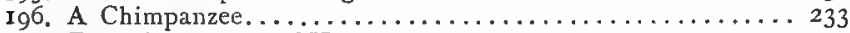

197. Feet of Ancestors of Horse .................... 244

198. A Pterodactyl............................ 245

199. The Archæopteryx......................... 246

200. Diagram of a Sea-squirt...................... 247

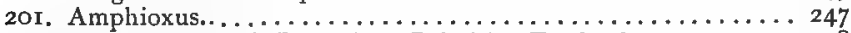

202. Growth of Frog's Lung from Primitive Food-tube........ 248

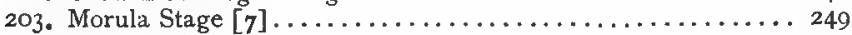

204. Gastrula Stage [7] ......................... 249

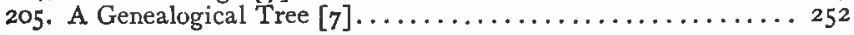

1. Our Household Insects. By E. A. Butler, Longmans, Green, \& Co.

2. LIFE IN PONDS AND

Streams...........ByW. Furneaux,

3. The Outdoor World...ByW. Furneaux,

4. Butterflies and Moths. By $W$. Furneaux,

5. Practical Elementary

BIOLOGY .............. By fohn Bidgood,

$\begin{array}{lll}66 & 66 & 66 \\ 66 & 66 & 66 \\ 66 & 66 & 66 \\ 66 & 66 & 66\end{array}$

6. Seaside Studies in Natu-

Ral History....By E. and A. Agassiz, Houghton, Mifflin, \& Co.

7. The Stok y of Creation. By Edw. Clodd, Longmans, Green, \& Co.

8. Animal Brology........By C. L. Morgan,

9. Quatn's Anatomy, ioth Edition.......... " "

II. Human Physiology......By W. Furneaux, Longmans, Green, \& Ca 



\section{ANIMAL ACTIVITIES.}

\section{CHAPTER I.}

\section{ANIMALS CLASSIFIED.}

IN the course of these lessons on Animal Activities the student will be called on to observe many forms of animal life and to learn many new and perhaps strange names. In order that he may keep his bearings and feel somewhat at home from the start, the following classification of the animal kingdom is given. The student should read over this table carefully, noting especially the meaning of the names in the light of their derivation, and he should refer to it frequently. Later in the book more will be said about classification.

The animal kingdom is divided by zoölogists into subkingdoms. As these subkingdoms are supposed to consist of animals related through their ancestry, they are sometimes called phyla (phylum, a tribe). Since Zoölogy is a rapidly growing science, authorities differ in regard to the number of divisions, or phyla, and also in regard to the names for some of the divisions. 


\begin{tabular}{|c|c|c|c|c|}
\hline $\begin{array}{l}\text { Phylum } \\
\text { or Sub- } \\
\text { kingdom. }\end{array}$ & $\begin{array}{l}\text { Name of Sub- } \\
\text { kingdom. }\end{array}$ & $\begin{array}{l}\text { Derivation of } \\
\text { Name. }\end{array}$ & A Few Characteristics. & Familiar Examples \\
\hline I. & PRO TO ZO'A. & $\begin{array}{l}\text { Gr. protos, } \\
\text { first, and } \\
\text { zoon, ani- } \\
\text { mal. }\end{array}$ & $\begin{array}{l}\text { One-celled ani- } \\
\text { mals. } \\
\text { They do not re- } \\
\text { produce by eggs. }\end{array}$ & $\begin{array}{l}\text { Amoba, para- } \\
\text { mecium, vor- } \\
\text { ticella, chalk } \\
\text { animals. }\end{array}$ \\
\hline II. & PO RIF'E RA. & $\begin{array}{l}\text { Lat. porus, } \\
\text { a pore, and } \\
\text { fero, to bear }\end{array}$ & $\begin{array}{l}\text { Animals having } \\
\text { many cells } \\
\text { much alike. } \\
\text { Food enters the } \\
\text { body by numer- } \\
\text { ous openings. }\end{array}$ & All sponges. \\
\hline III. & $\begin{array}{c}\text { CE LEN TE- } \\
\text { RA'TA. }\end{array}$ & $\begin{array}{l}\text { Gr. koilos, } \\
\text { hollow, and } \\
\text { enteron, in- } \\
\text { testine. }\end{array}$ & $\begin{array}{l}\text { Animals having } \\
\text { hollow cylindri- } \\
\text { cal bodies with } \\
\text { only one open- } \\
\text { ing, the mouth. }\end{array}$ & $\begin{array}{l}\text { Hydras, hy- } \\
\text { droids, jelly- } \\
\text { fish, corals, } \\
\text { sea.anemones }\end{array}$ \\
\hline IV. & $\begin{array}{l}\text { E CHI NO- } \\
\text { DER'MA TA. }\end{array}$ & $\begin{array}{l}\text { Gr. echinos, } \\
\text { a hedgehog, } \\
\text { and derma, } \\
\text { skin. }\end{array}$ & $\begin{array}{l}\text { Animals having } \\
\text { very distinct ra- } \\
\text { dial symmetry, } \\
\text { having hard } \\
\text { plates in the } \\
\text { skin, and fre- } \\
\text { quently covered } \\
\text { by spines. }\end{array}$ & $\begin{array}{l}\text { Starfish, sea- } \\
\text { urchins, sea- } \\
\text { cucumbers, } \\
\text { and stone- } \\
\text { lilies. }\end{array}$ \\
\hline V. & VER'MES. & $\begin{array}{l}\text { Lat. vermis, } \\
\text { a worm. }\end{array}$ & $\begin{array}{l}\text { Include a great } \\
\text { variety of worm- } \\
\text { like animals. } \\
\text { Some have seg- } \\
\text { mented bodies. }\end{array}$ & $\begin{array}{l}\text { Earthworms, } \\
\text { leeches. }\end{array}$ \\
\hline VI. & $\begin{array}{c}\text { AR THROP'O- } \\
\text { DA. }\end{array}$ & $\begin{array}{l}\text { Gr. arihron, } \\
\text { a joint, and } \\
\text { pous (pod), } \\
\text { a foot. }\end{array}$ & $\begin{array}{l}\text { Animals having } \\
\text { segmented bod- } \\
\text { ies and jointed } \\
\text { appendages. }\end{array}$ & $\begin{array}{l}\text { Grasshoppers, } \\
\text { butterflies, } \\
\text { spiders, cray- } \\
\text { fish, crabs, } \\
\text { centipedes. }\end{array}$ \\
\hline VII. & MOL IUS'CA. & $\begin{array}{l}\text { Lat. mollis, } \\
\text { soft. }\end{array}$ & $\begin{array}{l}\text { Soft-bodied ani- } \\
\text { mals, often en- } \\
\text { closed in hard } \\
\text { shells. }\end{array}$ & $\begin{array}{l}\text { Clams, snails, } \\
\text { the nautilus, } \\
\text { and the squid. }\end{array}$ \\
\hline VIII. & CHOR DA'TA. & $\begin{array}{l}\text { Gr. chorde, } \\
\text { a string. }\end{array}$ & $\begin{array}{l}\text { Almost all have } \\
\text { b a ck bo n e s } \\
\text { made up of parts } \\
\text { called vertebræ. }\end{array}$ & $\begin{array}{l}\text { Fishes, frogs, } \\
\text { turtles, } \\
\text { snakes, birds, } \\
\text { horses, and } \\
\text { man. }\end{array}$ \\
\hline
\end{tabular}


In the following pages directions are given for the laboratory study of the activities, as well as of the structure of the animals mentioned below.

A paramecium, belonging to Protozoa.

A sponge, belonging to Porifera.

A hydra and a hydroid colony, belonging to Cœlenterata.

A starfish and a sea-urchin, belonging to Echinodermata.

An earthworm, belonging to Vermes.

A grasshopper, a butterfly, a house-fly, a potatobeetle, a spider, a centipede, and a crayfish or a lobster, belonging to Arthropoda.

A mussel, a slug, and a snail, belonging to Mollusca. A fish, a frog, and a bird, belonging to Chordata. Directions for a short study of some domestic animals related to man are also given. 


\section{CHAPTER II.}

\section{MATERIAL FOR STUDY.}

IN order to study the activities of animals it is necessary (I) to have apparatus, (2) to collect many forms of animal life and provide suitable conditions for them, and (3) to prepare and preserve specimens. All work of this kind can best be done by the members of the class. It is a good plan for small groups of volunteers to assume responsibility for carrying out the directions of the several paragraphs which follow.

\section{APPARATUS AND REFERENCE BOOKS.}

Not much apparatus is needed. A net for collecting insects may be made by bending a piece of telegraphwire into the shape indicated in Fig. I, fastening it to

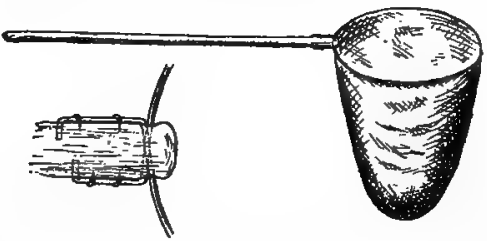

FIG. 1.-An Insect-net. Drawn by A. E. Sanford.

a pole, and sewing it into a bag made of mosquitonetting. For water collecting, a tin strainer attached to a wooden handle answers admirably. Fruit-jars and jelly-tumblers with tin covers make good collecting vessels. A few books should be at hand for reference. Bulletin No. 39, U. S. National Museum, can be had 
by sending to the National Museum in Washington. It contains valuable directions for collecting and preserving animals, and no school need be without it. "The Out-door World ", Furneaux, (Longmans,) is a useful help in this work.

Write your name plainly on a label affixed to the jar or other vessel in which you have placed your collections. Write a brief statement telling where and under what circumstances your specimens have been collected. Hand jar and statement to the teacher at the same time.

LIVING MATERIAL FOR FALL USE.

Grasshoppers and Crickets. Collect these insects and place them in tumblers, or similar glass vessels, covered with netting. Put earth in the bottom of each tumbler and keep it moist. Feed the insects with lettuce, or similar vegetable food. Watch the movements of male crickets while chirping. Female crickets may often be seen depositing eggs. The females may be recognized by the long, slender, egg-depositing organs at the end of the abdomen. Use these specimens with the directions in Chapter IV. Grasshoppers and crickets may be fed on bread.

Wasps and Butterflies. Place wasps in tumblers in a similar manner, and feed them on sugar and water. Try, also, butterflies

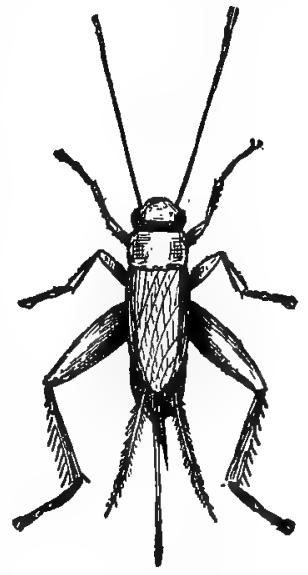

FIG. 2.-The Housecricket. and moths in the same way, using larger glass vessels. If eggs are deposited, examine them carefully and watch their growth. 
Caterpillars. Keep these singly in tumblers with fresh supplies of the plant on which they are found feeding. When many caterpillars are needed for class study a "breeding-cage" may be made by placing earth in the bottom of a

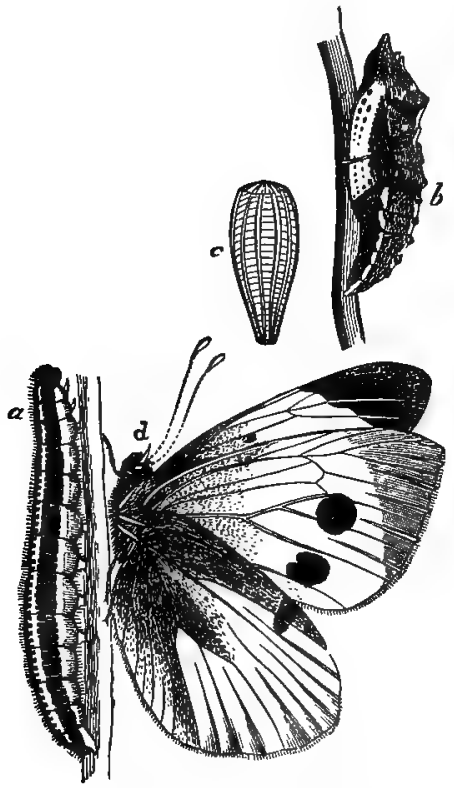

FIG. 3.-A Cabbage-butterfly. large box, covering the box with netting, and supplying plenty of food and moisture. If panes of glass can be set in the sides of the box, so much the better. Cabbageworms are easily obtained, and the butterflies can be reared from them with very little care. The cabbage - butterflies are sometimes called "whites". In observing butterflies and caterpillars use the questions in Chapter V.

Flies. Allow adult bluebottle flies to deposit eggs on pieces of meat or fish in tumblers. Watch the growth of the eggs. larva; $b$, pupa; $c$, egg; $d$, imago. ${ }^{a}$ Keep in a fairly warm place and furnish moisture. See further suggestions in Chapter VI. Houseflies may be watched in tumblers. Feed them on sugar and watch their movements. Early in the fall house-flies will deposit their eggs on stablemanure.

Spiders. All our common spiders are harmless. To collect spiders invert a tumbler over them, and imprison the insects by covering the mouth of the tumbler with a card. The garden-spider is a good one to 
observe. Provide flies and other small insects for food, and watch the web-making, the feeding, and other activities. Further questions and suggestions will be found in Chapter IX.

Earthworms. Fill one or two large battery-jars with moist earth and decaying leaves and put in each jar several earthworms. Cover the jars and keep the earth well moistened. Keep all winter. Watch in connection with directions in Chapter XIV.

Turtles and Snakes. Line the bottom of a large box with sheet-lead or zinc and place panes of glass in the sides for windows. Put earth, stones, and moss,

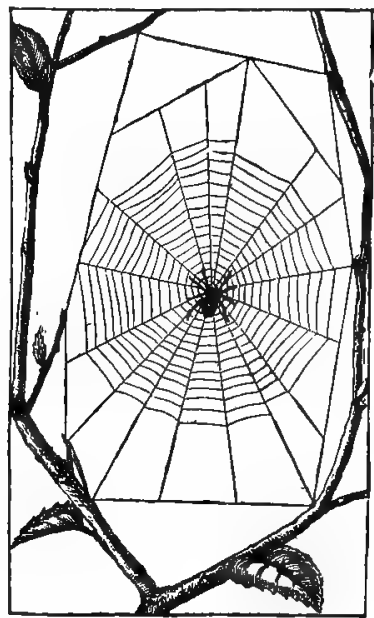

FIG. 4.-Spider and Web. and, if convenient, a few growing ferns in the box. This makes a good home for turtles and snakes. Snakes caught late in the fall will probably not eat anything through the winter, and they can be set at liberty in the spring. Turtles seldom eat in the winter, but will take flies, bits of meat, or pieces of cracker soaked in milk when hungry. "The Vivarium ", an illustrated book by G. C. Bateman, will be of great assistance to pupils who are willing to care for these animals.

Frogs. In a box like that described in the preceding paragraph keep several frogs. In the winter frogs do not commonly take food. Live frogs can usually be bought in the markets.

Slugs. These animals are easily kept if provided with moisture and food. They eat bread or cracker as well as many kinds of vegetables. 
Snails and Mussels. Collect pond-snails and put in a vessel of water with sticks, dead leaves, and growing plants. Place in the bottom of the dish two or three inches of sand and introduce one or two fresh-water mussels. Watch the movements of both snails and mussels. Find out how they breathe. The plants furnish food for the snails, and the mussels thrive without feeding, living FIG. 5.-A for years in an aquarium like that just deWater-snail scribed. Watch for the eggs and growing (Planorbis). young. Use directions in Chapter XV.

Aquaria. The mussels just mentioned breathe the air dissolved in the water, and, on this account, fresh air must be supplied. There are several ways of doing this. The simplest method consists in furnishing

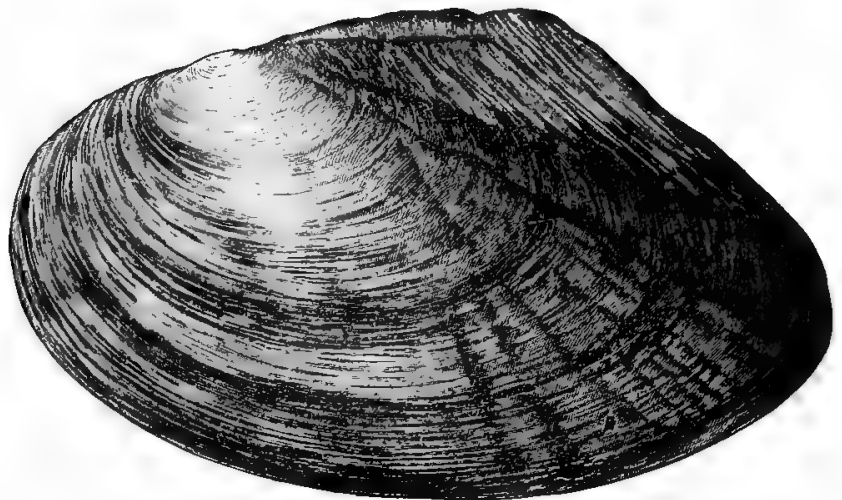

FIG. 6. -Shell of a Fresh-water Mussel (Anodon).

growing plants enough in the aquarium to take up the carbon dioxide gas exhaled by the animals, and at the same time to give the water a supply of oxygen. Such plants may be easily collected while looking for snails. Water-plants are also for sale at bird stores. 
Another method of purifying the air in water consists in forcing a stream of air through it. This is not practicable in most schoolrooms. Pouring fresh water against the side of the aquarium in such a way that many bubbles of air are caught in the descending stream is a common and easy method. Large aquaria frequently have a constant supply of running water with a regular outflow. Such aquaria are hardly necessary in most schools. Small rectangular glass vessels and

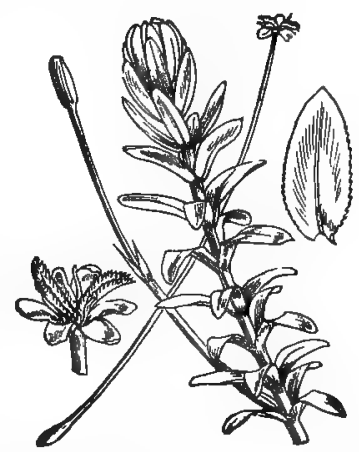

Fig. 7.-An American Pondweed. common battery-jars answer

every purpose. Of course water

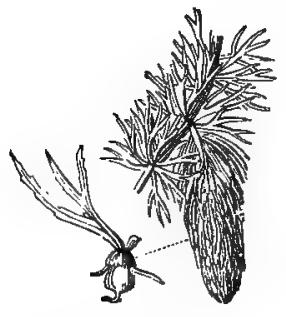

FIG. 8.-The Hornwort.

lost by evaporation must be replaced. With the aquatic animals mentioned here it is a good plan to depend partly on plants to change the air in the water, but in addition to this it is better to remove the greater part of the water from time to time and to replace it by a fresh supply. An easy way to accomplish this is to have all the aquaria placed on a shelf a little higher than the faucet from which water is to be supplied. A hose can be attached to the faucet for the purpose of filling the aquaria. In order to empty the vessels, it is only necessary to unscrew the hose from the faucet while it is still filled with water, being careful to

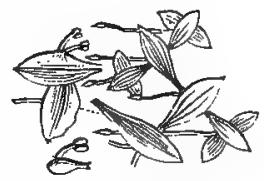

FIG. 9.-A Duckkeep the end of the hose in the aquarium under water. 
In this way the water siphons over into the sink. To prevent the passage of insects through the siphon, attach it to a tunnel

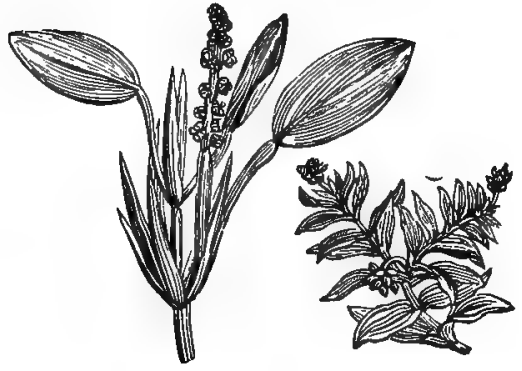

FIG. Io.-Other Pondweeds. having the opening covered with wire gauze.

Hydra. Collect small sticks and dead leaves, with some mud and water, from a freshwater pond, or from ditches used for draining swampy places. P l a c e these in glass with growing fresh-water plants, and renew from time to
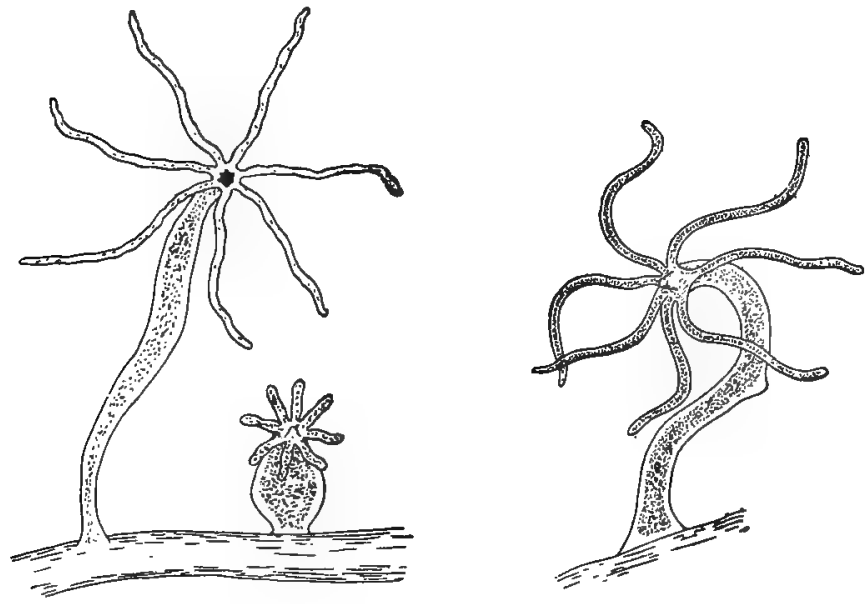

FIG. II.-The Hydra (magnified).

time the water lost by evaporation. Collect from several localities in separate jars, and label the jars 
for convenience. Watch carefully for the appearance of either brown or green hydras.

They may be seen without a magnifying-glass. If only eggs are present, they may not hatch for months,
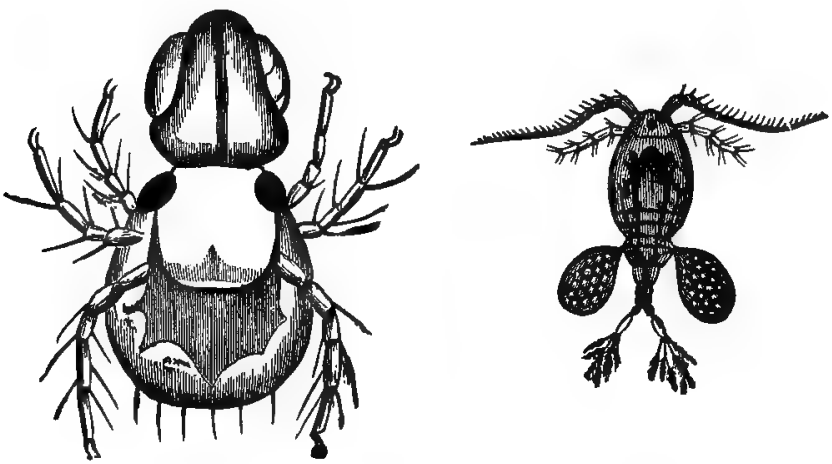

FIG. 12.-Water-fleas and Cyclops (magnified).

but sometimes adult hydras are captured attached to duckweed or other objects. Have several jars, and watch them all. Look for the appearance of buds on the sides of the hydras. Minute crustacea (water-fleas and Cyclops) may appear in some of the jars. These are good food for hydras, and themselves furnish pleasing objects for study, both with and without the microscope. If either crustacea or hydras appear, notice whether they prefer the light or the dark side of the jar. Add water only to replace that lost by evaporation.

Some Water-breathing Insects. While collecting the hydras, look for objects that appear like moving sticks, or small moving rolls made of bits of leaves or pieces of sand. These are the larvæ of caddis-flies. Watch them feed, and add material to the tubes which protect their delicate bodies. Keep plenty of plants about them. Larva of other insects may be collected 
at the same time and kept in aquaria. If possible collect a water-boatman. Fig. 72 shows this insect
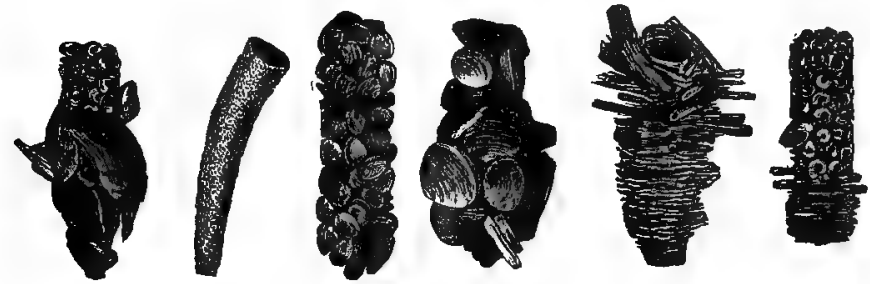

FIG. 13.-Caddis-fly Cases.

as it appears while swimming and while flying. A powerful aquatic insect is the large water-beetle (Ditycus Marginalis). Fig. I 5 shows the young and Fig.

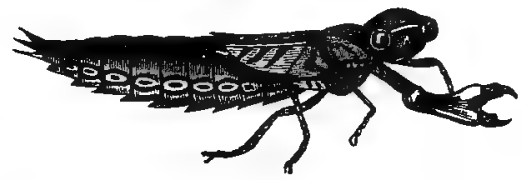

Fig. 14.-The Larva of a Dragon fly.
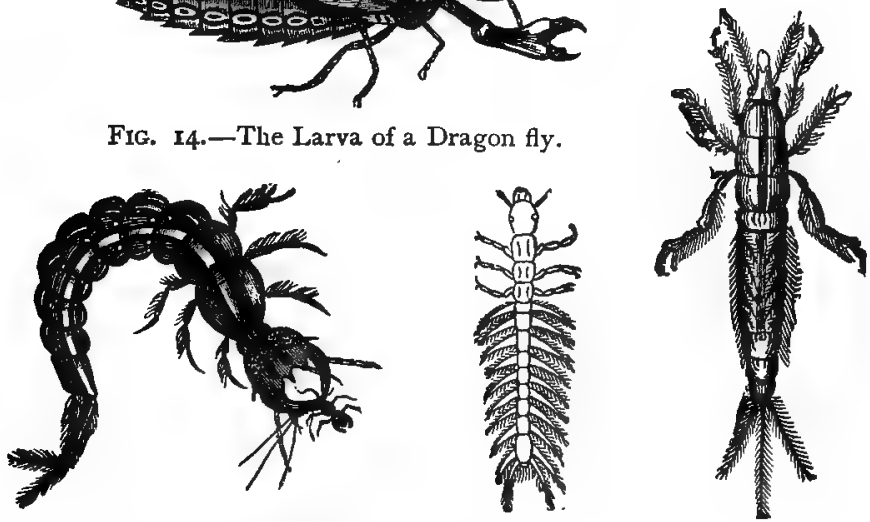

FIG. I5-Larva of Dyticus. FIG. 16.-Larva of FIG. I7.-Larva Whirligig Beetle. of a May-fly.

73 shows the adult forms. The whirligig beetles seen in large numbers on the surface of fresh water have eyes adapted for seeing enemies in the air above and 
in the water below at the same time. A young whirligig is shown in Fig. I6. Watch mode of breathing and of carrying air about. Observe also the manner of "feathering" the oars. Feed the beetle and larvæ on bits of meat or small insects.

Leeches. "Blood-suckers", as the boys call them, are harmless and interesting tenants of an aquarium. Watch some of these animals, noting especially the mode of movement by means of contracting longitudinal and circular muscles. They feed only occasionally, and can be set at liberty before they suffer for food. At liberty they suck the blood from living animals.

Crayfish. These may be bought alive in the mar-

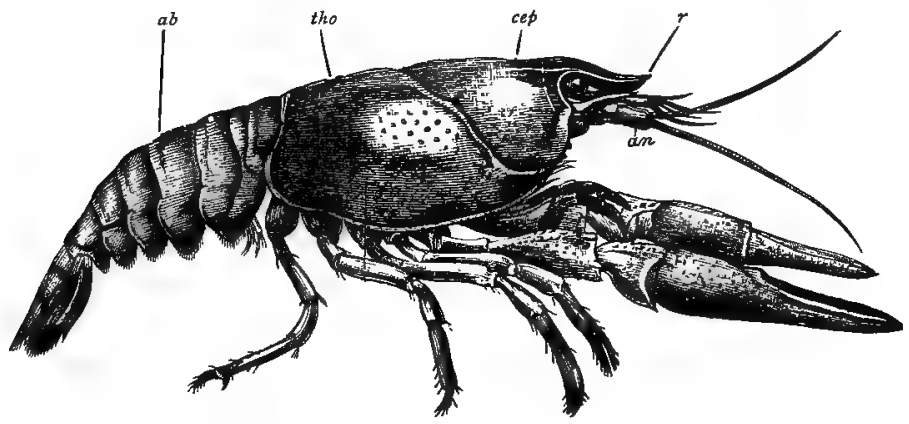

FIG. 18. - Side View of Crayfish. an, antenna; $r$, rostrum; cep, cephalic portion; tho, thoracic portion of cephalothorax; $a b$, abdomen.

kets. They may be kept in shallow water in aquaria and fed on bits of fish or meat.

Tadpoles. These may be caught in ponds and brooks even late in the fall. Collect several sizes and keep them in a jar or jars. They feed on vegetable matter, eating chiefly the small green plants (confervæ) which grow so rapidly in stagnant water exposed to sunlight. Select a particular individual and sketch his 
actual size from time to time, dating the sketches. Make these sketches as accurate as possible. When not convenient to catch tadpoles it is easy to buy them.

Fishes. Obtain alive, by using a net, either horned pout (catfish) or bream. Goldfish can be bought in case of failure to get others. Feed with fish-food, a preparation of gelatin sold by dealers in goldfish. Use plants in the aquarium, and change the water about three times a week. Use a rectangular aquarium. Shield from the direct rays of the sun.

Hydroids and Jelly-fish. Unless a school is situated where it is easy to obtain an abundant supply of salt water, not many marine animals can be well kept. Before undertaking seashore work, a copy of "Seaside
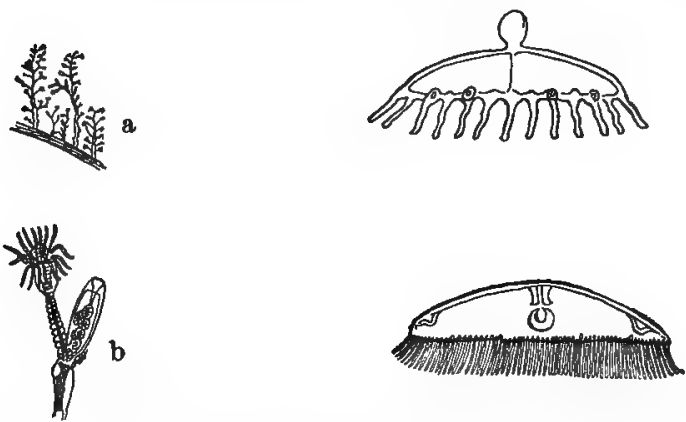

Frg. 19.-A Campanularian Hydroid Colony (Eucope diaphana). a, whole colony, one half natural size; $b$, single zooid magnified; $c$ and $d$, stages of jelly-fish, magnified.

Studies " (Agassiz) should be accessible to both teacher and pupils. There are many small marine animals resembling the hydra. Among the most abundant of these are the campanularian hydroids, colonies of hydralike animals. The colonies are brown in color, and look like mosses or similar plants. They grow on 
sea-weeds, on logs and sticks, and are sometimes attached to the shells of mussels. Find them at low tide and transfer them to a marine aquarium, made by filling a jar with salt water and introducing some marine plants collected on the rocks where the campanularians are found. Some closely related colonies are called sertularians. Hydractinia is the name given to a colony consisting of pink, salt-water hydroids found growing on the snail-shells occupied by hermit-crabs.

Sea-anemones. These animals are hardy and may be transported for some distance in jars or pails of salt water. To obtain them, look in pools left by the tide in rocky places, or on rocky bottoms below low tide. They are sometimes found attached to the piles of wharves or

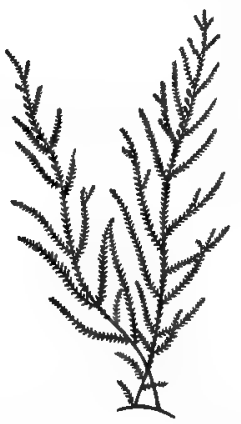

FIG. 20.-A Sertularian Colony. After Agassiz.

bridges. They can be removed from the rocks by quickly slipping a broad, thin knife between the anemone and the rock. Their resemblance to hydras and to coral animals

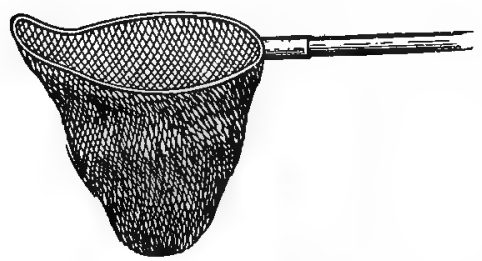

FIG. 21.-A Net for Collecting at the Seaside.

Starfishes and Sea-urchins. These animals may be found in the same localities as the anemones. They are quite hardy and will live in salt-water aquaria. As they can be collected at any time during the year, it is as well to get the living specimens when ready to study 
Chapter XIII. Keep one animal in each battery-jar with sea-water and a few marine plants.

Sea-cucumbers. These animals are often found on beaches after a storm. They may be found on rocky bottoms in a depth of from three to six feet of water at

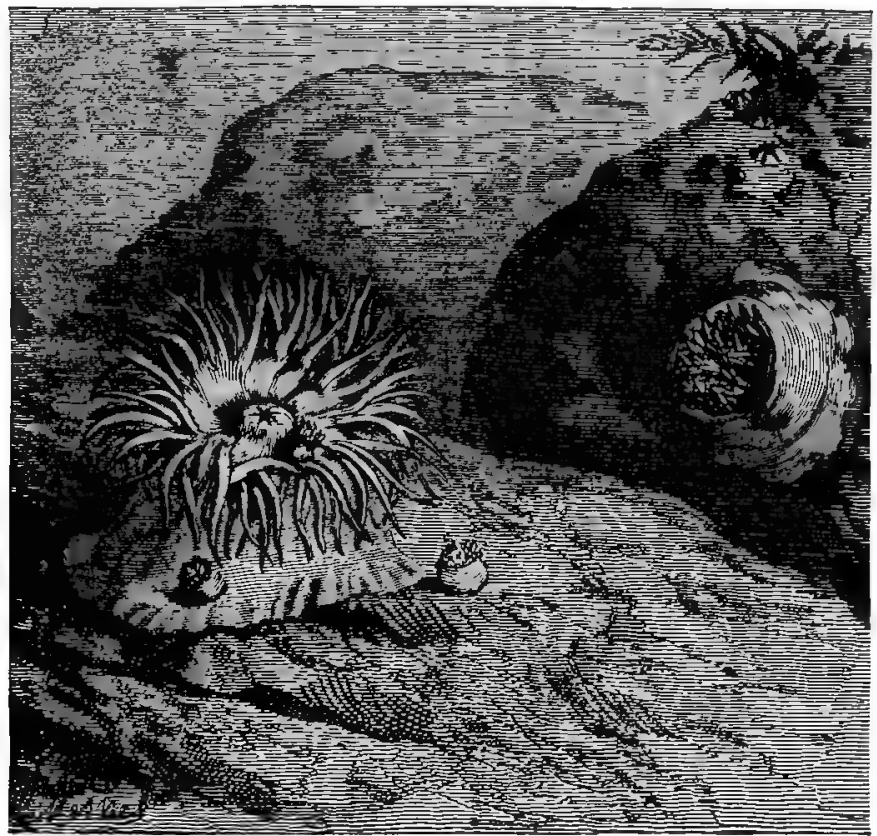

FxG. 22.-Sea-anemones.

low tide. It is easy to take them with a dip-net when once found. They are hardy and live well in aquaria. Compare with starfish and sea-urchin.

Shrimps and Sand-fleas. Shrimps may be used instead of crayfish in studying Chapter X. They may be caught with a dip-net in shallow water at low tide. They can be kept in aquaria. Sand-fleas, sometimes called 
sand-hoppers, are easily collected by overturning rocks left by the tide. Com pare with shrimps. Collect also hermit-crabs.

Marine $\mathbf{F}$ is $\mathbf{h}$. Where there are conveniences for salt-water animals, a few small marine fish may be kept. No special directions are necessary. Co m p a r e with other specimens of fish and use with Chapter XVI.

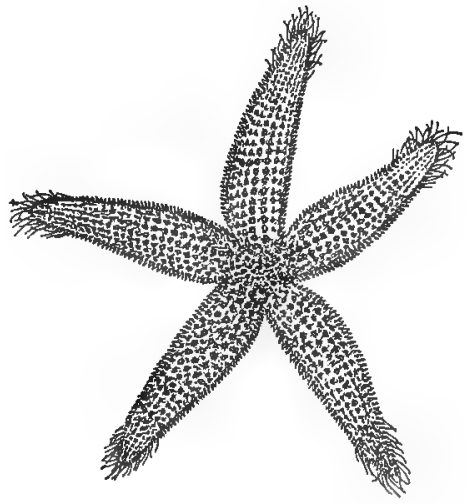

FIG. 23.-A Starfish. After Agassiz.

THE PREPARATION AND CARE OF SPECIMENS.

Prepared Specimens. In addition to living animals it is always necessary to have at hand a plentiful supply

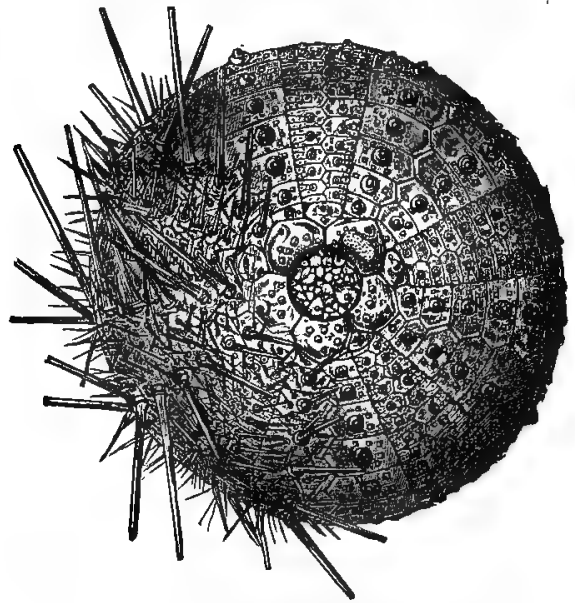

FIG. 24.-A Sea-urchin. Part of the spines have been removed. 
of prepared specimens so preserved as to be examined to the best advantage. It should be a part of the work of the pupil to prepare at least a portion of this material.

Killing the Specimens. Place some pieces of blotting-paper saturated with chloroform or ether in the

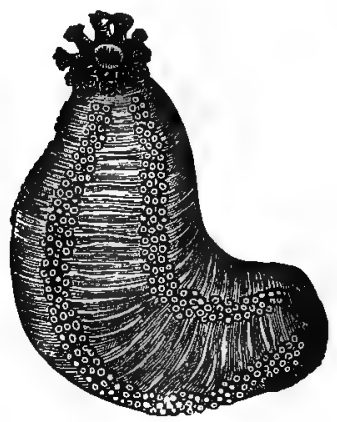

Frg. 25.-A Sea-cucumber.

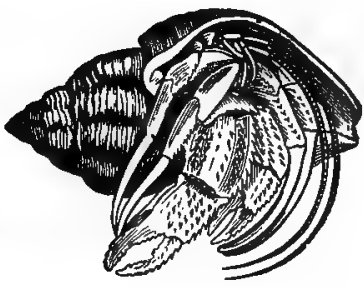

Fig. 26.-A Hermit-crab.

bottom of a jelly-tumbler provided with a tin cover (Fig. 28). In this grasshoppers, butterflies, and other small insects may be painlessly killed. It must be remembered that chloroform and ether are poisonous

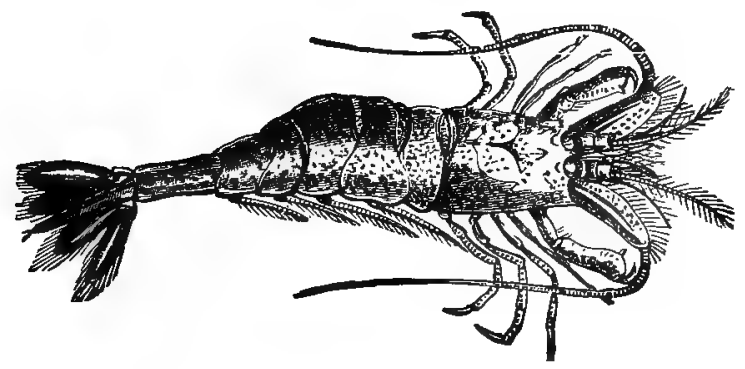

Fig. 27.-A Shrimp.

substances, and that they must not be brought near a lighted lamp or fire, as they ignite very readily. 
The cyanide bottle described in Part F of Bulletin No. 39, U. S. National Museum, can be used instead of the tumbler if desired. Animals larger than insects may be killed by chloroform or ether. Earthworms should be killed in dilute alcohol. Starfish and seaurchins are often killed by placing them in hot, but not boiling, water.

Preserving Specimens in Alcohol. Part M of Bulletin No. 39 already mentioned gives valuable directions for the preservation of specimens. Alcohol is the most important preserving fluid. For most specimens $50 \%$ alcohol should be used at first. This should be changed in a few

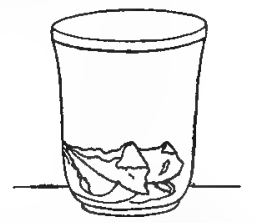

FIG. 28. - Tumbler with Chloroform. Drawn by A, E. Sanford. days to a stronger solution, about $60 \%$. If the specimens are to be permanently kept they should be transferred again to $70 \%$ alcohol. Strong alcohol as bought of the dealers is about 95\% pure. This should be diluted some days before the specimens are put in it, to prevent the collecting of bubbles on the surface of the animals. Parts of animals for dissecting should be hardened gradually in alcohol. Hydras, hydroids, snails, mussels, and worms are best kept in alcohol.

Preserving Specimens in Formalin. This liquid as usually bought is a solution of formaldehyde in water. For most purposes it should be diluted with water to make a $2 \%$ solution. Specimens to be used are kept in this fluid.

Dried Specimens. For class use, butterflies may be kept in a tightly closed box containing naphthalin or camphor. Such specimens usually need to be preserved for a few months at most and can then be thrown away. Dragon-flies and other insects may be kept in the same box. Starfish may be dried by a slow heat after immersing for a time in hot water, not boiling, or after gradually hardening in alcohol. Sea-urchins may be 
preserved in the same way, but they make better specimens for study, if preserved in formalin or alcohol.

Shells and Bones. To remove snails from their shells put them in hot water for a few moments. The shells may then be cleaned and dried. To clean fleshy matter from a skeleton like that of the starfish use a dilute solution of caustic potash. Sometimes it is well to boil specimens in that liquid. The bones of larger animals can be cleaned enough for class use by simply boiling and removing the fleshy parts. When such specimens are to be kept for a long time more care is needed, and books containing more specific directions should be consulted. Part C of Bulletin No. 39, previously mentioned, is helpful.

MATERIAL FOR WINTER AND SPRING.

The preceding directions are for classes which begin Zoölogy in the fall. When the work begins in the

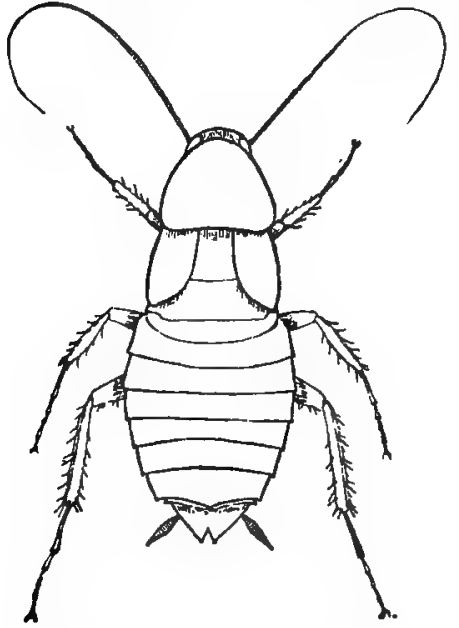

FIG. 29.-A Cockroach. spring the order of work should be modified somewhat, beginning with Protozoa and reaching the subject of Arthropoda after warm we a t $h$ er brings the living specimens again w it h in easy reach. Even in winter much material can be procured by the pupils for their study.

Cockroaches. Cockroaches were originally southern insects. They a r e now distributed almost everywhere, and are fairly abundant even in cold weather. They are most easily collected at 
night in warm places where there is a plentiful supply of household food. A sugar-refinery often furnishes an abundant supply of these insects. They may be kept alive as in the case of grasshoppers. With a few obvious changes in the directions and questions, the cockroach may be substituted for the grasshopper in studying Chapter III.

Butterflies and Moths. Although adult forms of these insects are not abundant in cold weather, their eggs, cocoons, and chrysalids are easily obtained. In late winter or early spring pupils should collect specimens of the large mourning-cloak butterfly (Vanessa

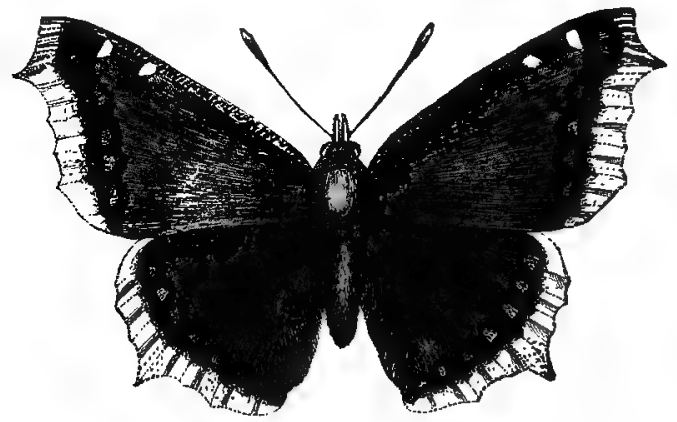

Fig. 30.-Mourning-cloak Butterfly (Vanessa antiopa).

antiopa), which shows the wear due to its winter sleep, and is ready to produce eggs for the summer brood. The eggs may be reared, the larvæ feeding on leaves of willow or birch. On apple-and cherry-trees may be found the eggs of the tent-caterpillar moth. These eggs are glued to the stem in a mass. The large grayish-brown cocoons of the Cecropia moth are often found on pear-trees or other fruit-trees. Eggs, cocoons, and chrysalids should be brought to the schoolroom and placed under such conditions that hatching and growth may be watched. 
Other Insects. Eggs of spiders are easily found in winter. They should be kept in tumblers and watched. Nests of paper-making wasps are interesting. They often contain sleeping queens waiting for a higher tem-

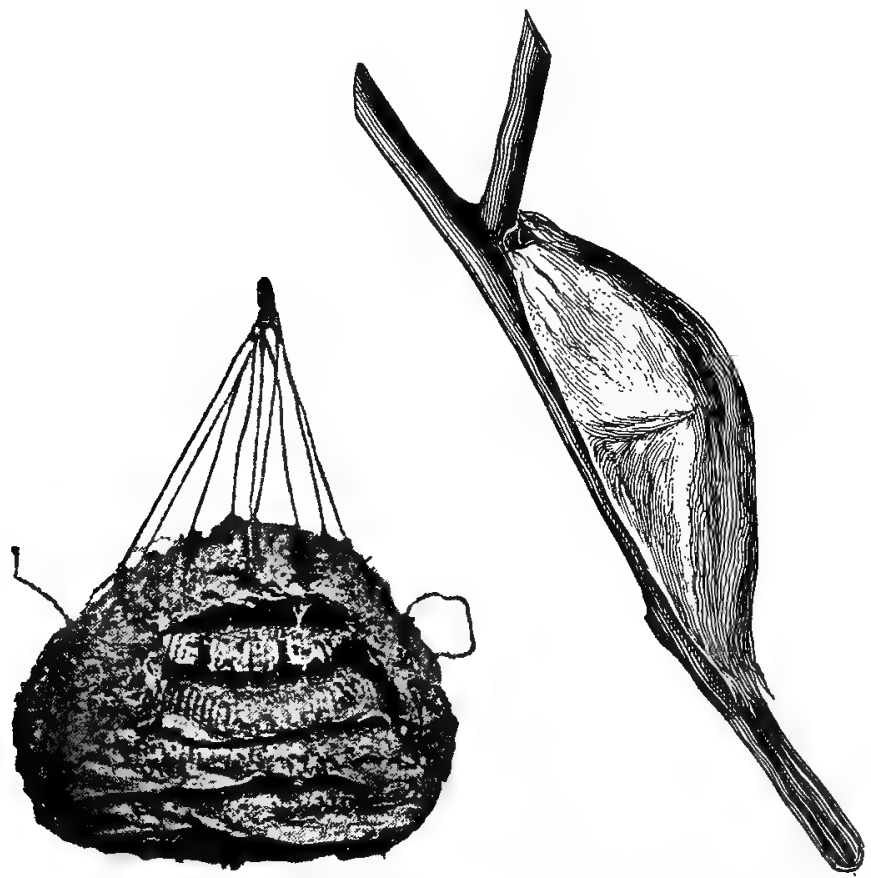

FIG. 31.-A Wasp's Nest.

FIG. 32.-_Cocoon of Cecropia. From a Photograph.

perature in order to start other colonies. Insects in various stages of metamorphosis pass the winter hidden away from birds and other enemies. Locality and circumstances must determine what sort of specimens pupils should search for. With the advent of spring one can obtain nearly, if not quite, all the specimens already mentioned as obtainable in the fall. 
For Aquaria. Hydroids, hydras, and jelly-fish for the most part die off in winter, but sea-anemones, starfish, hermit-crabs, shrimps, and crayfish can all be obtained throughout the year. Snails and mussels are also easily kept at all times, as are also tadpoles and frogs.

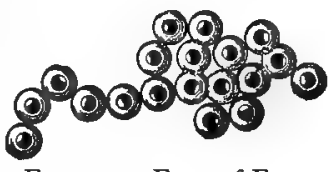

FIG. 33.-Eggs of Frog just Laid.

In the spring the eggs of frogs and toads should be placed in aquaria and watched.

Birds. Winter is the best time to begin the outdoor study of birds. Familiarity with the birds which remain north throughout the winter prevents much of

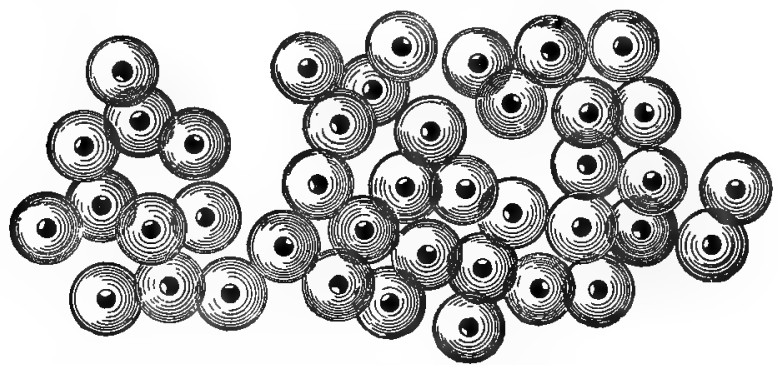

FiG. 34.-Eggs of Frog a Few Hours after Laying.

the confusion which so annoys the novice when he tries to observe the newcomers at the time of the spring migration. A study of crows, blue jays, and chickadees, during cold weather should form a part of the work for winter. English sparrows must not be despised as objects of study, and their habits, both in captivity and out of doors, should be watched. 


\section{CHAPTER III.}

\section{ACTIVITIES COMMON TO ALL ANIMALS.}

Matter. The books on physics tell us that matter is anything having extension, i.e., having length, breadth, and thickness. Living matter we call organic, and matter which is not alive, and, as far as we can see, never has been alive, we call inorganic.

Living Matter. Living matter dies. It always returns sooner or later to the inorganic world from which it derives the materials by means of which it keeps its living machinery active.

Organisms grow, not by adding matter to the outside, as do crystals when they increase in size, but by taking substances into the body, and there building them into matter like themselves.

Before growth ceases, plants and animals reproduce. Some small portion of the body separates from the rest and begins an independent existence, repeating, very nearly, the life-history of its parents. In most cases the part which separates for the new life must join with a part of another individual before it can grow. Doubtless pollen and ovule are familiar terms to all who will use this book.

Living things, too, seem to be capable of movements which differ from the movements of inorganic things. A living tree moves with the wind just as inorganic things move, but it also has going on within it movements which differ entirely from any movements of which inorganic matter is capable. 
Plants and Animals. The differences between higher animals and plants are so obvious that we need never mistake one for the other; but, as we shall see, the differences grow less and less as we consider simpler and simpler organisms. Among the simplest living bodies the processes of life go on; but we do not know whether to call the living things themselves plants or animals.

Definitions. The science which treats of living matter is Biology. The branch of Biology treating of plants is Botany, and the branch treating of animals is Zoölogy.

The study of the form, structure, and position of the parts of a plant or an animal is Anatomy. Minute Anatomy studied with the microscope is Histology.

The study of the functions or uses of all parts of an organism is Physiology.

Activities of our own Bodies. We may learn what the most important activities of animals are by considering the chief activities of our own bodies. While our ability to move readily from place to place, and to perform the many muscular acts of daily life, is doubtless the most noticeable sort of activity which we share with other animals, it is not the most fundamental. Back of all movement there must be a source of power. In these days, men make machines which seem almost alive. In these some sort of power which we can understand causes all the movements. Springs and weights move clocks, steam-pressure turns the wheels of factories, and electric currents move our street cars.

Our Bodies Chemical Engines. Sources of power can usually be traced back to heat. The movements of a steam-engine are due to energy set free by the burning of coal. The burning of coal is a chemical activity. The heat is caused by the union of two elements, carbon and oxygen. It has been found that the movements of living things are also due very largely to chemical action. Just as coal burns or 
oxidizes in a furnace and produces energy or power to work, so the various materials of which our bodies are made oxidize and set free the energy by which we perform the varied movements of our bodies. In a very true sense, then, our bodies may be called chemical engines.

Waste and Repair. The furnace which furnishes power for any kind of machinery must constantly receive new material and give out waste products. Without a constant supply of coal and air, the fire goes out and work stops. The chimney must be kept clean in order to allow the gases produced by the fire to pass out, and the ashes must be raked away as fast as they are formed, to make space for new fuel. In the same way every living animal takes into its body substances corresponding to the fuel of a furnace, and it as constantly gives out the waste products which would soon cause death if they should remain. In order that we may know these substances better, a few simple experiments may be considered.

Experiment. Water. Using the apparatus shown in Fig. 35, pour water and a

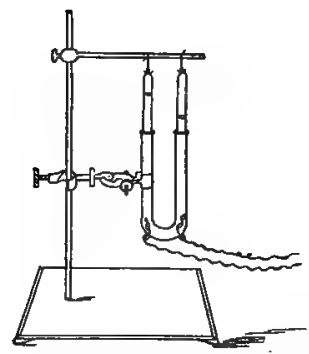

FIG. 35--Apparatus for Decomposing Water. Drawn by A. E. Sanford. little sulphuric acid into the $U$ tube, and place test-tubes filled with water over the ends of the wires. When the circuit is closed notice that bubbles of gas arise from the wires and collect in the upper part of the test-tubes. Note the fact that water is separated by a current of electricity into two invisible gases, and that, after a time, one tube contains twice as much gas as the other. The larger amount of gas is hydrogen, and the smaller, oxygen. Light the hydrogen, noting the fact that it burns very readily. Into the top of the 
tube containing oxygen thrust a glowing coal (carbon) and see that it relights. Water is composed of two gases. Hydrogen burns easily in air, and oxygen aids the burning of hydrogen, of carbon, and of other substances.

Elements and Compounds. Because hydrogen and oxygen cannot be further separated into other substances they are called elements. Water, because it is formed by the union of two elements, is called a compound. Carbon is also an element.

Experiment. The Oxidation of Magnesium. Magnesium is an element. To a piece of wire made of this element apply a lighted match and notice the production of heat and light. Examine the white powder produced. The oxygen from the air has united with magnesium and formed magnesium oxide. This white powder, the magnesium oxide, weighs more than the magnesium used. The process is oxidation.

The oxidation of hydrogen produces hydrogen oxide, or water. The oxidation of carbon produces carbon oxide, commonly called carbon dioxide. Magnesium oxide is a solid, hydrogen oxide is a liquid, and carbon dioxide is a gas. In all cases heat and energy are produced by oxidation.

Experiment. The Oxidation of Phosphorus. Phosphorus is an element obtained from the bones of animals. Caution must be used in experiments with phosphorus as it ignites so readily. Remove a piece of phosphorus from the water and allow it to dry on a piece of blotting-paper. Note the smoke arising. This is phosphorus oxide. Touch the phosphorus with a warm wire. Note the increased rapidity of the oxidation. The same amount of heat is produced by the oxidation of phosphorus whether the oxidation is slow or rapid. Phosphorus oxide is formed in both cases.

Experiment. Nitrogen in the Air. Air is almost wholly a mixture of nitrogen and oxygen.' Cover the top of a large cork with asbestos and put on it a small 
piece of phosphorus. Float the cork on water in a soup-plate and light the phosphorus, at the same time lowering over it a jar of air, in such a manner that the

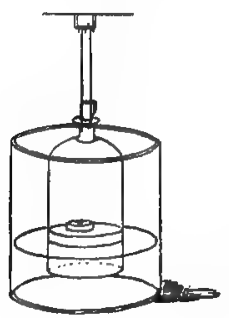

Fig. 36.-Apparatus for Removing Oxygen from Air. Drawn by A, E. Sanford. mouth of the jar just dips below the surface of the water in the plate (Fig. 36). The phosphorus oxide formed dissolves quickly in the water. The water rises in the jar to replace the oxygen used up, showing that about one fifth of air is oxygen.

Remove the jar from the plate and thrust into the gas a lighted match. This colorless gas forming about four fifths of the air is nitrogen. It will not burn or aid the burning of other substances. This element is found in all animal bodies united with other elements to form compounds. Bread and meat contain compounds partly composed of nitrogen.

Experiment. The Element Carbon in Starch and Sugar. Heat in the bottom of a testtube a small amount of sugar (Fig. 37). Notice the water which collects on the sides of the tube. What are two elements found in sugar?

Heat slowly until no more steam escapes, break the tube and examine the residue. It is charcoal, a form of carbon. What three elements in sugar?

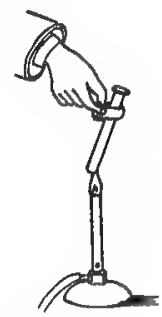

Repeat this experiment, using starch and wood.

Graphite and diamond are other forms of carbon.

Experiment. Carbon Dioxide. Burn in a covered bottle a little charcoal attached to a wire. When it ceases to glow remove it, and shake up the gas in the 
bottle with lime-water. The milky appearance of the water proves that the gas, carbon dioxide, is present in the bottle. How did the gas get in the bottle?

Expcriment. Carbon Dioxide in the Breath. Breathe through a glass tube into a test-tube containing a little lime-water. What does the milky appearance of the lime-water prove? Whence came the carbon dioxide? How was it produced?

Experiment. The Oxidation of Hydrogen in our Eodic's. What collects when we breathe on a cold glass? Whence comes the water? The hydrogen enters the body with the food. How does the oxygen enter the body?

Substances Taken into the Body and Substances Excreted. It has been found that the greater part of the substances taken into the body are compounds of hydrogen, oxygen, nitrogen, and carbon. These enter the body as food. Oxygen also enters the body in breathing. It has been found that the substances regularly excreted from the body by the lungs, by the skin, and by the kidneys are carbon dioxide, water or hydrogen oxide, and a compound containing nitrogen and hydrogen, called urea. In this way the four elements which enter the body as complex compounds are all finally excreted as very simple compounds.

A Summary of Activities. All animals take food of some kind. As in our bodies, so in the bodies of all other animals, the food must be chemically changed to build up tissues and furnish material for oxidation. Although all other animals do not have lungs, skin, and kidneys like ours, they nevertheless must excrete the materials which result from the oxidations and other chemical changes in the body. All animals also reproduce. All are capable of movements different from the movements of inorganic things. All, too, are able in some way to establish communication with the outside world. For this purpose we are endowed with 
special organs for seeing, hearing, smelling, tasting, and feeling. By these organs we discover the world about us. Many animals have not these organs of sense. Many, indeed, have no organs of any kind, yet all animals secm to possess, to some extent, the ability to discover their surroundings. If no other sense be present, something like our sense of feeling seems to be always active.

We may summarize the most important activities of animals as follows:

(a) Taking food and oxygen.

(b) Nutrition.

(c) Excretion.

(d) Reproduction.

(e) Movement.

(f) Discovery.

Respiration combines in most animals the two important functions of taking oxygen and excreting waste matter.

Physiology and Anatomy. In studying animals we wish most of all to know their activities. But in order to understand these activities one must know certain facts about the structure of the animals to be studied. A sewing-machine has only one activity or function, but one must know the form and position of many parts before one knows just how the sewing is done. When we speak of the six activities mentioned we are dealing with Physiology. When we study the parts of an organism to learn their positions and shapes we are dealing with Anatomy. Evidently, then, anatomy and physiology must be studied together in the science of Zoölogy. We do not study anatomy in order to become familiar with many new names, but in order to understand the activities or uses of the parts. 


\section{VOCABULARY.}

A nat'o my (Gr. ana, up, and temno, cut), the science which treats of the structure of organisms.

$\mathrm{Bi} \mathrm{ol}^{\prime} 0 \mathrm{gy}$ (Gr. bios, life, and logos, a discourse), the science of living things.

Bot'a ny (Gr. botania, a plant), that part of Biology which treats of plants.

Car'bon (Lat. carbo, coal), an element found in all organic compounds; charcoal, graphite, and diamonds are forms of this element.

Car'bon di ox'ide, a heavy, colorless gas, formed by the breathing of animals and by the burning of substances containing casbon.

Ex cre'tion (Lat. ex, out, and cerno, separate), the act of throwing off waste matters from the body.

Func'tion (Lat. fungor, execute), the action of any part or organ of a plant or animal.

His tol'o gy (Gr. histos, a web, or tissue, and logos), the study of minute anatomy.

Hy'dro gen (Gr. hydor, water, and gignomai, be born), a colorless, gaseous element forming a part of water.

In or gan'ic, not organic.

Mag ne'si um (Gr. Magnésios, a district in Thessaly), a silverwhite, solid, metallic element.

Mat'ter (Lat. materia, stuft), anything having extension.

Ni'tro gen (Gr. nitron, nitre, and gignomai), a colorless, gaseous element composing four fifths of the air.

Nu tri'tion (Lat. nutrio, feed), a series of processes by which living things maintain their life and growth by appropriating food.

Or gan'ic (Gr. organon, an organ), pertaining to plants and animals.

$0 x$ i da'tion, the process of uniting chemically with oxygen.

Or'gan ism, a living plant or animal.

Ox'y gen (Gr. oxys, sharp, and gignomai), a colorless, gaseous element, forming one fifth of the air.

Phys i ol'o gy (Gr. physis, nature, and logos), the science which treats of living things.

Zo ol'o gy (Gr. zoon, an animal, and logos), that part of biology which treats of animals. 


\section{CHAPTER IV.}

\section{GRASSHOPPERS AND CRICKETS.}

Directions for Work. Collcct full-grown and partly grown locusts or grasshoppers. Place some of the living insects in tumblers with fresh lettuce-leaves. Allow ventilation. Why? Watch the insects carefully and compare with a prepared specimen. In your note-book answer the questions below.

Shape of Body. What is the shape of the body? Are the two sides alike (bilateral symmetry)?

Is the skeleton or hard part of the body cxternal or internal?

The Abdomen. The chief divisions of the body arc the head, thorax, and abdomen. How many segrments has the abdomen?

Count the segments of the abdomen in several specimens. Is the number the same in all cases?

Do you find a row of breathing-holes (spiracles) along either side of the abdomen ?

Do you find a ridge running lengthwise along the abdomen just below the spiracles? This riclge represents the softer parts of the segments. These softer portions enable the insect to move the upper and lower parts of the segments farther apart to take in air while inhaling. When they are brought together again the air is expelled. The upper hard part of each segment is called the tergum, the under part is the stcrnum, and the more flexible part on either side the plcurum. Can you see the movement of the abdomen made by breathing? 
Do you find the so-called ear-drum 'tympanum, on the first segment $r$ the abdomen?

The female grasshopper has organs at the end of the abdomen for placing her eggs in the ground (ovipositors)-

Do you find both ma:e and female grasshoppers: Sketch a side view of a grasshopper's abdomen $X$ :

The Thorax. What appendages are attached to the thorax? How many segments in the throrar?

How many legs do you find? Are they ininted? How do they differ in size? Sketch one of the hind legs, indicating all the parts $\times \equiv$

How many rings do you see? Are any of the wings folded? How? Sketch a front and a hind wing fully extended $\% 5$.

To what segments are the wings attached?

What can you say of tive grasshopper's powers of locomotion? How many times its length can a grasshopper jump? Do the grasshoppers you have seen use their wings when they jump? How do the wings of young grasshoppers compare with those of full-grown insects?

The Head. How many feelers do you find $n$ the front of the head (antenna)? Are they segmented? What is their shape? How does their length compare with the length of the body? Sketch a side view the head showing feelers.

How many eyes do you find? Compound eyes are made up of parts called facets. Small, simple eyes are called ocelli. How many compound eyes has the grasshopper? How many ocelli? Where are the eyes and ocelli situated? Sketch a part of a compound eye as seen under a microscope.

What is the shape of the upper lip (labrum; ? Sketch.

Under this lip do you find hard jaws (mandibles; ? How many? What color? What shape? In what direction do they move? Sketch. 
Do you find a tongue?

Do you find a pair of softer jaws (maxilla) behind the mandibles? Sketch.

What is the shape of the lower lip (labium)?

Do any of the mouth-parts have feelers (palpi)? Where situated? How many?

Does the insect bite or suck its food? Notice the movements of its mouth-parts.

Touch gently the grasshopper's feelers with a toothpick or stick. Touch in the same way other parts of the body. Where is it most sensitive to touch ?

How far can a grasshopper see? How do you determine this? Can the grasshopper hear? Give a reason for your answer. Does the grasshopper have the sense of smell?

What can you now say about the grasshopper's mode of taking food? its respiration? locomotion? its organs of sense or discovery?

Summary of Drawings, (a) Side view of abdomen $\times 5$.

(b) Sketch of one of the second and one of the third pair of legs $\times 5$.

The parts of the leg. beginning at their union with the body, are coxa, trochanter, femur, tibia, and tarsus. Indicate these parts in your drawing.

(c) Sketch of front and hind wings $\times 5$.

(d) Side view of a grasshopper's head $\times 5$.

(e) Sketch of mandible $\times$ IO.

$(f)$ Sketch of maxilla $\times 10$.

(g) Sketch of upper lip $\times 20$.

(l) Section of compound eye (microscope).

Internal Structure. If we wish to examine the internal structure of a grasshopper, we may prepare specimens by hardening them in alcohol. This changes the color and to some extent alters the size and general appearance of the organs. On this account it is well to examine a freshly killed specimen along with the alcoholic specimen for purposes of comparison. 
For the purpose of dissection a female grasshopper should be pinned to the bottom of a dissecting-pan and covered with water. The dorsal wall of the abdomen should then be cut away with a pair of scissors, care being taken to notice the delicate tube, the heart, lying along the back. In the freshly killed specimens, the

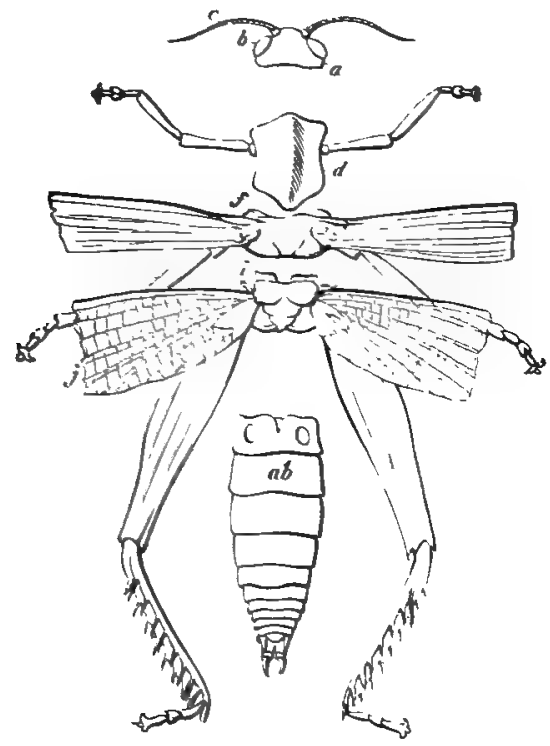

FIG, 38 . - The Parts of a Locust. $a$, head; $b$, eye; $c$, antenna; $d, f, i$, thorax; $a b$, abdomen.

trachex, or air-tubes, connecting with the spiracles on the outside, and ramifying to all parts of the body, may be easily seen. At the same time a cluster of long, oval, yellow eggs may be seen on each side of the body, near the anterior part of the abdomen. From these a tube, the oviduct, leads backward to the oripositors. Below the heart the digestive canal may be 
seen, consisting of the csophagus, or gullet, a large crop, a stomach with many tubes called gastric cæca, and an intestine reaching to the anal opening. Lying along the ventral portion of the abdomen are masses of nerve-matter called ganglia, a double mass or pair of ganglia to each segment. These are connected by nerves. All the ganglia, with one exception, the supraœesophageal ganglion, or brain, lie below the digestive tract.

This arrangement of organs, the heart dorsal, the nervous system ventral, and the digestive tube between is characteristic of insects. It is interesting to observe
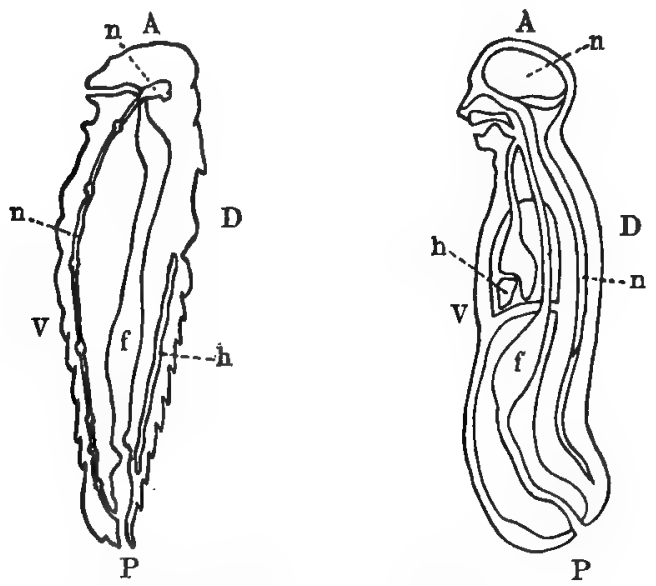

FIG. 39.-Comparison of Grasshopper and Man. $A$, anterior; $P$, posterior; $D$, dorsal; $V$, ventral; $n$, nervous system; $h$, heart; $f$, foodtube.

how this arrangement compares with that in the human body (Fig. 39).

Taking Food. The grasshopper lives entirely on vegetable food. Although its mouth-parts appear much complicated, they are well adapted for their 
work. The palpi feel about and locate the juicy parts of plants, the maxillie seize and hold them in position, while the hard mandibles tear the food into bits and pass it along to the discestive organs.

Plants are able to build from mineral substances the materials which are useful food for the grasshopper, thus illustrating the well-known fact that without plants animals would die. Even animals which never eat plants subsist on other animals which depend on plant-food. As far as we know animals are unable to take nitrogen unless it has been previously made into plant-tissues which are suitable for animal food.

Nutrition. It is not our purpose here to describe in detail the processes of nutrition in animals having so highly developed a digestive system as we find in the srasshopper. It is enough to say that the food pusse's through a long tube extending from the mouth to the anal opening at the posterior part of the body. This tube is often called the food-tube or alimentary cullal. In the grasshopper and similar insects it is enlarsed in one place to form a gizzard or grinding stomach. In some grasshoppers this gizzard is armed with teeth. There are also two other enlargements known as the crop and the stomach. In its course through this tube the food is acted upon by fluids which soften it and change it chemically so that the nutritive portion is able to soak through the walls of the ford-tube into the blood, which distributes it to all parts of the body, where it is used to build up tissue or to serve as fuel for heating the body. The portion of the frod which is not so softened passes through the tube and is finally expelled from the body at the anal opening.

\section{Respiration. Taking 0xygen and Excreting Waste} Substances. Food is uscless to animals without a supply- of air and an outlet for carbon dioxide, water, and urea. Man regularly inhales and expels air about eighteen times a minute. This process is so important 
that we often speak of the "Breath of Life". If we cover the holes along the sides of the grasshopper's body, so that no air can enter, he dies, just as we should die if deprived of air. Throughout animal life this same necessity for air exists.

The air used by the grasshopper for breathing purposes enters the body through little holes along the sides of its abdo-

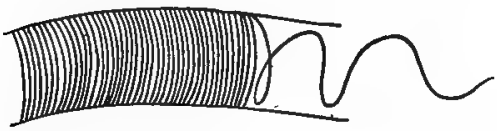

Fig. 40.-The Trachea of an Insect (magni. fied). men and thorax. Eight of these openings may be easily $\mathrm{s}$ e e $\mathrm{n}$ on each side of the abdomen, a n d $\mathrm{t} w$ o others o $\mathrm{n}$ each side of the thorax. These holes, or spiracles, open into air-tubes, called tracheæ, which divide and subdivide in order to send branches to every part of the body, even into the wings. These tubes and their branches are surrounded by blood-vessels through which blood is constantly coursing. The oxygen of the air filters through the walls of the trachea into the blood, and the carbon dioxide, water, and other waste substances in the blood pass through the same walls in the opposite direction. Such an interchange of gases through a membrane is called osmosis. Not only do these breathing-tubes carry oxygen to the blood and remove the waste products of respiration, but they also render the body very light, enabling the insect to rise easily in the air. In addition to excreting waste substances by breathing, the grasshopper pours urea into the food-tube and thence out of the body.

Reproduction. But animals or plants never eat enough to make them grow or live forever. In many common plants a single cell, called an ovum, is set apart and fertilized by union with another cell to form a seed, which, under proper conditions, reproduces the plant. In the grasshopper the egg corresponds to the 
seed of the plant. It, too, is a single fertilized cell set apart for reproduction. The grasshopper deposits her eggs in the ground, using for this purpose the ovipositors at the end of her abdomen. From these eggs there hatch tiny insects much like their parents in shape, but destitute of wings. After a few days of eating, the little grasshopper becomes too large for his hard skin (exoskeleton), and proceeds to change it. The process of crawling out of the old skin is called
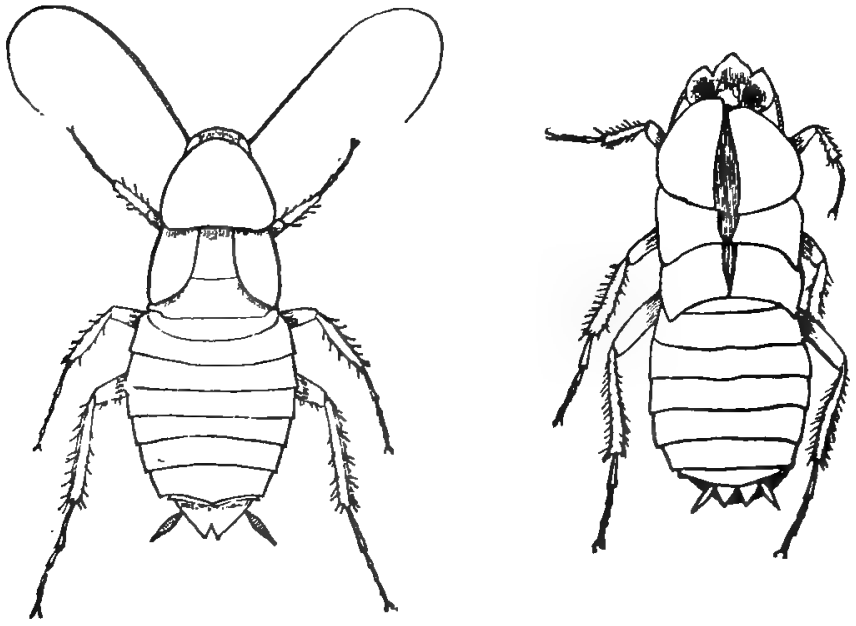

FIG. 41.-Cockroacl and Cast Skin.

moulting. In this way he moults five times, after each moult appearing in every way more like the parent grasshopper. Like most other insects grasshoppers deposit an enormous number of eggs.

Discovery. If one touches a stone it does not move, but if, on the other hand, one touches the feelers of a grasshopper, or moves a stick in front of its eyes, there is a movement in response to the irritation. This movement is usually entirely involuntary, like the 
movement of the eyelids when a sudden blow is threatened. Very simple and familiar illustrations of this power are common even among plants. In higher animals the response to external stimuli is often so complicated with voluntary movements that the two can hardly be distinguished, but in every animal there doubtless exists the power to respond in some way to movements of the world outside its own body. These movements may affect the animal through simple touch, or through any or all of the other senses. Every animal has at least one of the five senses.

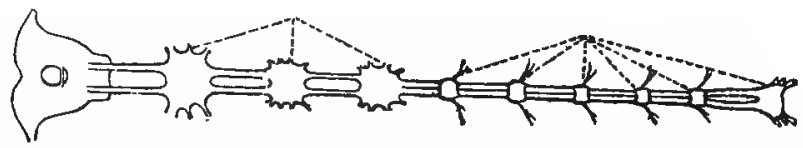

FIG. 42.-The Nervous Chain of a Cockroach.

Sight. Although the eyes of the grasshopper are large and composed of many parts, his power of vision is doubtless far inferior to ours. Many experiments have been made on the sight of insects, and all seem to show that they can neither see far nor clearly. The compound eyes of insects, as we have seen, are made up of many hexagonal facets. Each of these facets has a tiny lens for focussing the rays of light on a nerve which transmits vibrations caused by these rays to the nerve-centres within.

Hearing. The hearing of the grasshopper is probably more acute than his sense of sight. Vibrations of the air set in motion the ear-drum on the first segment of the abdomen, and these are conveyed to nerves which connect with nerve-centres in the thorax. The fact that grasshoppers and their relatives are able to make noises which doubtless are understood by their friends is a reason for believing that they can hear. These noises do not issue from organs of speech 
like ours, but are more like the sounds we produce when playing on a violin. Careful observation of a male cricket will best show us a method of stridulating, as this process of insect-talking is called. Watching a cricket as he stridulates, one can see that the outer wings are raised and rapidly moved from side to side. If, now, the wing be examined with a microscope, a clear membrane reminding us of a drum-head will be seen on each wing, and on the under side of each

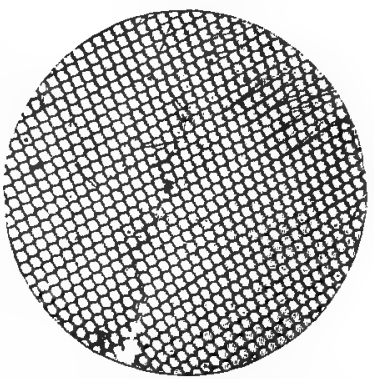

FIg. 43.-Portion of the Cornea of a Fly's Compound Eye (magnified). outer wing will be found an enlarged roughened crossvein which is used like the bow of a violin, being drawn

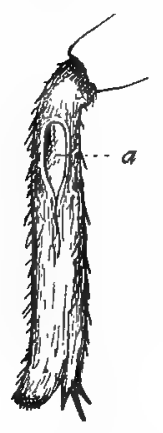

FIG. 44.-The

$\mathrm{H}$ e a ring Organ of a C r i c k e t (magnified). across the edge of the opposite wingcover to set in motion the membranous drum-heads.

The cricket's organ of hearing is situated on the tibia of the front leg. Some insects hear by means of hairs on the antennæ or elsewhere which move in unison with vibrations about them. In some cases insects may be able to hear sounds entirely inaudible to human ears.

Taste and Smell. The sense of taste probably resides in the palpi. That the grasshopper can smell is evident from the way in which he chooses his food, and also from the fact that certain odors seem disagreeable to him.

Touch. That the grasshopper possesses the sense of touch is easy to prove, and that the antenna are especially sensitive as tactile organs is equally evident. The antennæ are provided with 
hairs which seem to increase their sensibility, and they are connected with the nerve-centres within the body, as are the other organs of sense.

Movements. In addition to the motion called forth by irritation of the sense-organs, the grasshopper is evidently able to move on his own account. He can walk, fly, or jump where and when he wishes. The

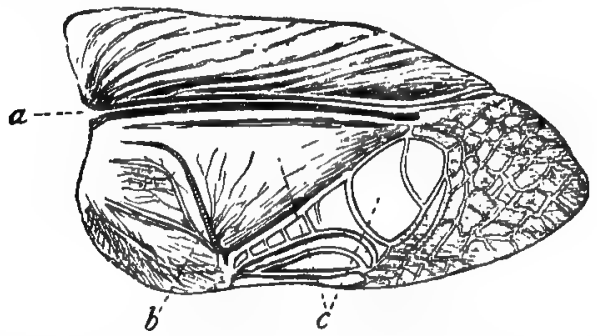

FIG. 45.-The Stridulating Organ of a Cricket. $u$, large vein; $b$, roughened cross-vein; $c$, membrane.

adaptation of the legs to the mode of life needs no comment. The structure of the wings, however, may be briefly considered. The wings are outgrowths of the hard exoskeleton. They are composed of a framework of double tubes over which is stretched a membrane. The inner tube of one of the veins carries air. The outer tube surrounding this is filled with blood. Thus the wing becomes an organ of respiration as well as an organ of flight. Lightness and strength are also obtained at the same time.

Comparison of Grasshopper and Cricket. Crickets are easily collected. They may be studied in the same way as the grasshopper. In writing notes concerning the cricket, make use of the new descriptive words learned while studying the grasshopper. Write in your note-book only such facts as can be made out from the specimens. At the top of the page in your note-book write "Grasshopper and Cricket". Draw a vertical 
line down the middle of the page. At the top of one column write "Resemblances", and at the top of the other column write "Differences". In these spaces write all the resemblances and differences you can make out from actual observation.

Notice with especial care the tibia of the front leg in order to see the ear-drum.

Look on the under side of the wing-cover of the male cricket for the roughened vein used in stridulating.

The pair of appendages at the end of the abdomen are called stylets.

Make a drawing of a cricket as you see it.

Questions. I. How do a grasshopper's activities differ from those of man?

2. Is it an advantage in insect-life to have the nervous system on the ventral part of the body? Why?

3. In what respects is a segmented body an advantage to an animal ?

4. At what time of year are grasshoppers most abundant?

5. Whence come the grasshoppers seen in the fields in spring?

6 . Would it be wise to rid the world of grasshoppers? Why?

7. Why does the grasshopper breathe? What chemical changes occur in breathing ?

8. What is the color of the grasshopper's blood?

9. What senses has the grasshopper?

IO. What are the differences between organic and inorganic things?

I I. What are the points of similarity?

12. What are some of the differences between plants and animals?

Topics for Reports. The Locust Scourge. Locusts as Food. How to Destroy Locusts. The Life-history of a Locust. The Cockroach. Crickets. Walkingsticks. 


\section{VOCABULARY.}

$A b$ do'men (derivation uncertain), the posterior part of the body in insects.

An ten'na, pl. antenna (Gr. ana, up, and teino, stretch), a feeler growing from the head of an in. sect.

An te'ri or (Lat. ante, before), front.

Bi lat'er al (Lat. bis, twice, and latus, side), having two sides alike.

Chi'tin (Gr. chiton, a tunic), the horny substance forming the exoskeleton of insects.

Cox'a (Lat. coxa, the hip), the joint of an insect's leg next the body.

Dor'sal (Lat. dorsum, the back), opposed to ventral.

Fac'et (a diminutive of face), a part of a compound eye.

Fe'mur (Lat. femur, the thigh), the thigh.

La'bi um (Lat. labium, lip), the lower lip of an insect.

La'brum (Lat. labrum, lip), the upper lip of an insect.

Man'di ble (Lat. mando, chew), the hard, biting jaw of an insect.

Max il'la (Lat. macero, soften), the softer jaw behind the mandibles of an insect.

Mes o tho'rax (Gr. mesos, middle, and thorax), the middle segment of the thorax.

Me'ta mor'pho sis (Gr. meta, over or beyond, and morpho, form), the changes which take place in an animal from egg to adult.

Met a tho'rax, the posterior segment of the thorax.

Moult (Lat. muto, change), the shedding or casting of the exoskeleton.

Nymph (Gr. nymphĕ, a bride), a name applied to the young of some nsects, as the grasshopper.
0 cel'lus (Lat. dim. of oculus, eye), a small eye.

O vi pos'i tor (Lat. ovum, egg, and pono, place), an instrument for depositing eggs.

Pal'pus, pl. palpi (Lat. palpo, feel), a feeler growing from one of the mouth-parts.

Pleu'rum (Gr. pleuron, rib), the side of the seyment of an insect. See Fig.

Pos te'ri or (Lat. post, after), hind. er.

Pro tho'rax (Gr. pro, before, and thorax), the first segment of the thorax.

Spir'a cle (Lat. spiraculum, airhole), a breathing-hole.

Ster'num (Gr. sternon, breast), the ventral portion of the segment of an insect.

Strid u la'tion (Lat. strido, creak), a creaking noise made by insects.

Tar'sus (Gr. tarsos, a flat surface), the foot of an insect.

Ter'gum (Lat. tergum, back), the dorsal part of the segment of an insect.

Tho'rax (Gr. thorax, the chest), the middle division of an insect's body.

Tib'i a (Lat. tibia, shin-bone), the part of an insect's leg between the femur and foot.

Tra'che a (Gr. tracheia, rough), one of the breathing-tubes of an insect.

Tro chan'ter (Gr. trecho, run), a part of an insect's leg between the coxa and femur.

Tym'pa num (Gr. tympanon, a drum), an ear-drum.

Ven'tral (Lat. venter, the belly), pertaining to the belly, the part opposite the back. 


\section{CHAPTER V.}

\section{BUTTERFLIES AND MOTHS WITH THEIR PROTECTIVE DEVICES.}

Directions for Work. Watch the caterpillars which have been collected in accordance with the directions previously given. Record the changes that occur.

How many segments of the caterpillar have legs ?

How many of these legs are jointed?

If the jointed legs are attached only to the thorax, how many segments has the thorax?

Does the caterpillar have eyes? antennæ? palpi ?

Do you find mandibles and maxillæ?

Some of the caterpillars will change to chrysalids soon after collecting.

In one of these chrysalids can you find head, thorax, and abdomen?

Is the chrysalis capable of any movement ?

Can you find antennæ, eyes, or palpi ?

Do you find wings or legs?

Can you see parts of any organs under the skin?

Collect several common yellow butterflies, or the white cabbage-butterflies.

Where do you find them?

At what time in the day do they seem to be most active?

On what plants do they feed?

How do they take their food?

Notice how they fly and how they walk.

How do they hold their wings when at rest?

Secure some eggs, if possible, and watch their development. 
The Prepared Specimen. Examine the butterfly after it has been killed, and write the resemblances and differences for butterfly and grasshopper as in the case of grasshopper and cricket. Consider all the points noted concerning the grasshopper. Consider the stages of growth.

Study with care the coiled tongue, or proboscis. Uncoil it and find out how it is used.

Remove the dust from a part of the wing. Is this part of the wing now colored? With a microscope
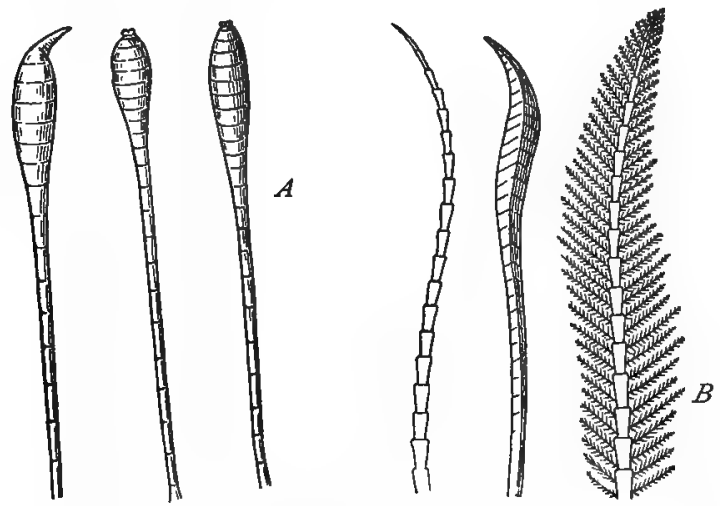

FIG. 46.-Antennæ of Lepidoptera. $A$, of butterflies; $B$, of moths.

note the shape of the particles of dust (scales). Note also how they are arranged on the wing.

Measure the spread of the wings, the length and width of the anterior wings and of the posterior wings, the length of the body, and the length of the antennæ.

Describe the color above and below, and state the color and location of the markings you find.

Notice the color of the feet, the antennæ, and the eyes.

Read the description of this butterfly in a good reference book, and compare your own observations wity. those there recorded. 
Irite a description of a butterfly whose name is unknown to you.

Irite a description of a moth.

Summary of Drawings. (a) The wings as seen from above when fully extended.

(b) Side view of butterfly with wings closed.

(c) Side view of head-enlarged_-showing proboscis and eye.

(d) Imaginary cross-section of proboscis.

(e) Larva, pupa, and imago of some butterfly not figured in the text-book.

$(f)$ The scales from a butterfly's wing as seen with a microscope.

$(g)$ A portion of a wing, showing the arrangement of the scales.

How to Tell Moths from. Butterflies. Butterflies and moths are much alike. They may generally be distinguished by the fact that the butterfly has knobbed antennæ, holds its wings erect in repose, and flies more often in the daytime. The moths often have feathered antennæ, fold their wings horizontally over the back when at rest, and more often fy at night.

Metamorphosis. The internal structure of the butterfly closely resembles that of the grasshopper, but
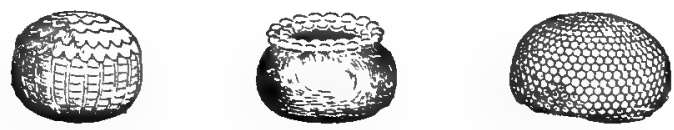

FIG. 47.-Eggs of Lepidoptera.

a striking difference appears in its metamorphosis, or the change it undergoes during its period of growth. The young grasshopper when it emerges from the egg looks much like the adult insect; from which it differs chiefly in its smaller size and in possessing smaller wings. A series of changes like that observed in the case of the grasshopper is spoken of as incom- 
plete metamorphosis. On the other hand, there emerges from the egg of the butterfly a worm-like animal totally unlike its parents, who, could they see their offspring, would doubtless disown it. This
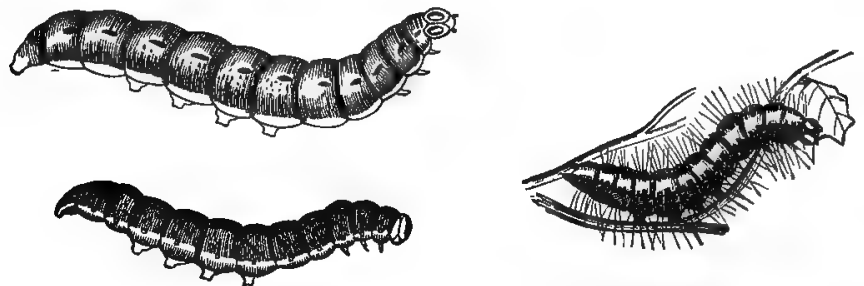

Fig. 48.-Some Larra of Lepidoptera.

larva, as we have seen, has biting mouth-parts, fitting it to subsist on the leaves of plants. It eats voraciously, consuming many times its weight of food during its short life, and increasing rapidly in size. It
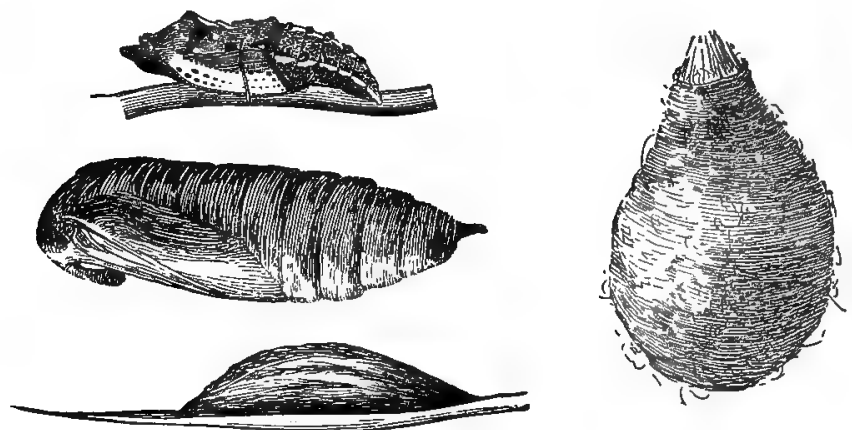

Fig. 49.-Some Cocoons and Chrysalids.

moults from time to time as its skin becomes too small for its fast-growing body. During this period of its life it is usually a destructive pest. The ravages of many caterpillars are already too well known. 
Finally, the larva seems to have eaten enough. It brings to a close its life of unceasing feeding and prepares for a period of sleep. Often it spins a silken cocoon in which it rests throughout the winter; sometimes it hangs by a single thread to a rock or fencerail, its exoskeleton making a beautiful chrysalis ornamented with spots of burnished silver, jet, and gold; again it buries itself in the ground to await the genial warmth of returning spring. In any case it takes no food and seldom moves, but within its body changes progress, until the full-grown butterfly or moth breaks through the hard case of the pupa, stretches and dries its wings for a short time, and flies away for its brief period of aerial life.

The full-grown butterfly, or imago, no longer eats the coarse food familiar to its larval stage. In fact, it could not do so if it

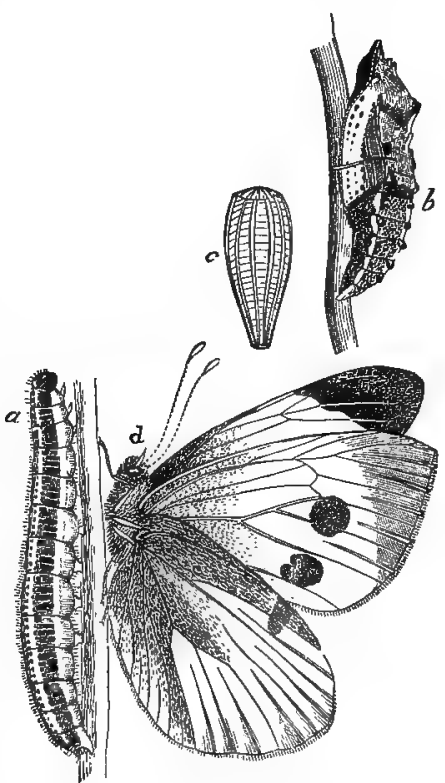

FIG. 50.-A Cabbage-butterfly. $a$, larva; $b$, pupa; $c$, egg; $d$, imago. would, for its mouth is no longer fitted for biting, but is provided with a long proboscis with which it sucks honey from its favorite flowers. This series of changes is known as complete metamorphosis (Fig. 50).

Structure of the Proboscis. The proboscis is a curious organ and well repays careful study. It is composed of two long half-tubes which are produce. 
by the elongating of the maxillæ of the caterpillar while it is in the pupa stage. These join by their

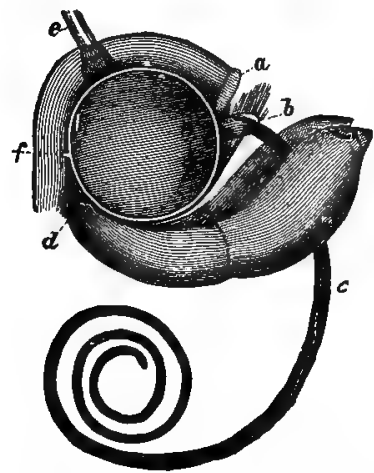

FIG. 5I.-Head of a Moth. $a$, upper lip; $b$, mandibles; $c$, proboscis; $d$, under lip; $e$, antennæ; $f$, eye. edges to form a complete tube which the butterfly can coil or uncoil at will and insert in the flower on which it feeds. At the upper part of this proboscis there is a pump-like cavity provided with a valve. When this enlarges, the tip of the tube being inserted in the cup of honey, the liquid flows up the tube and fills the cavity. The cavity then contracts under the influence of the surrounding muscles. This causes a pressure which compels the valve to close and forces the honey forward into the stomach (Fig. 5I).

Depositing Eggs. At the adult period of its life, however, the butterfly is not a great eater. Its most important function, now, is reproduction, and for this purpose the female butterfly searches for the plant which will furnish suitable food for her young brood of caterpillars and deposits there her eggs, dying soon after the performance of this function. The eggs of the clover-butterfly are placed upon the under side of clover-leaves, one to each leaf. The eggs of the tentcaterpillar, so common on apple- and cherry-trees, are laid in large clusters glued to the branch of the tree by a gummy substance produced by the moth depositing the eggs. In many cases the eggs of butterflies and moths show beautiful markings when studied with the aid of the microscope.

Butterfly Enemies. If all the eggs of all the butterflies and moths should be allowed to reach maturity 
during a single season they would kill all vegetation on the earth. The number of eggs deposited is enormous, and the few which reach the caterpillar stage make great havoc with our orchards, and often with our shade-trees. The gypsy-moth alone, in spite

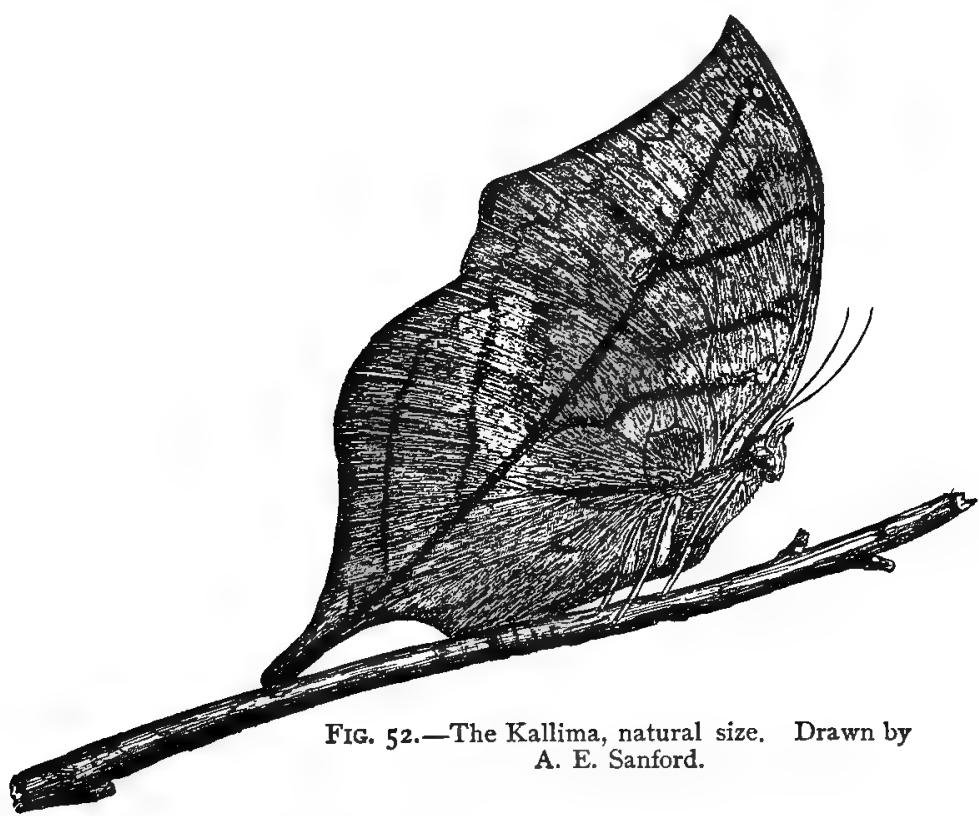

of great efforts, still does much damage. The number and activity of caterpillar and butterfly enemies in most cases holds them in check and allows only a small number to come to maturity. Both two-winged and four-winged flies deposit their eggs on the larvæ or pupæ of butterflies or moths. When these eggs hatch they produce larvæ which feed on the fat and muscle of their involuntary host and finally destroy its life. A living, but nearly dead, caterpillar bearing on 
its back a great number of pupa-cases of such flies is no uncommon sight (Fig. 67). Birds, too, devour immense numbers of insects in all stages of growth. Doubtless they would kill and eat all the insects were it not for the fact that many of them are so wonderfully protected by their color or shape, or both.

Protective Coloration. A butterfly or moth when pursued often disappears as if by magic, and only the most careful search reveals its presence. Then it is

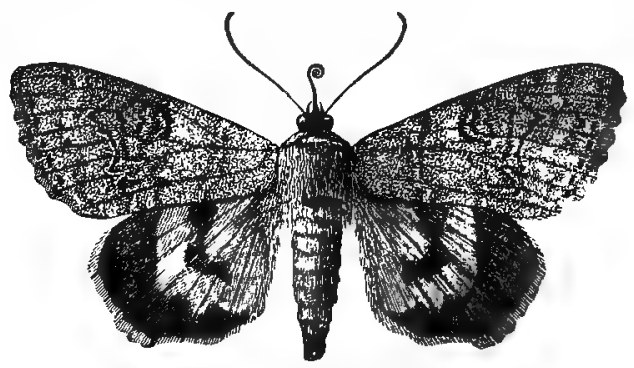

FIG. 53.-Catocala Nupta.

seen that the insect has been rendered invisible, not by the helmet of Perseus, but by its resemblance to some natural object common in its vicinity. The Kallima, a large and brilliant butterfly of India, folds its wings and alights on a branch. The folding of the wings conceals every brilliant color, and the under side of the wing, which is now alone visible, resembles so accurately a leaf that a bird could find it only with great difficulty (Fig. 52).

Some of our common moths, belonging to the genus Catocala, have outer wings so closely resembling the bark of birch-. poplar-, or willow-trees that when they alight on one of these trees they cannot be seen by a casual observer. Other cases of protective coloring are to be met with at every turn in the study of Zoölogy, and it is a part of the work of the student to find and describe them. 
Mimicry. The common milkweed-butterfly has a disagreeable odor and probably a disagreeable taste. On this account it is not a favorite food for birds. The
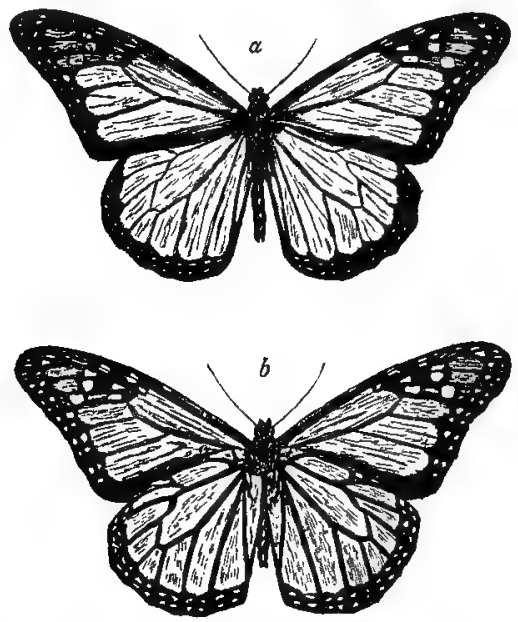

FIG. 54.-The Milkweed-butterfly. $a$, dorsal view; $b$, ventral view. One half natural size. Drawn by A. E. Sanford.

$a$

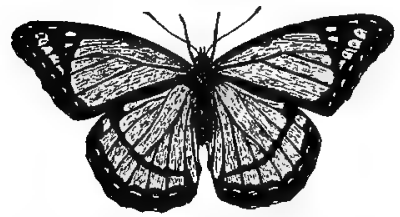

$b$

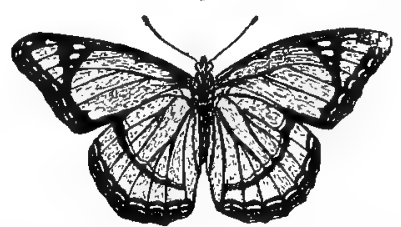

FIG. 55.-Limenitis Ursula. $a$, dorsal view ; $b$, ventral view. One half natural size. Drawn by A. E. Sanford.

Limenitis ursula, a smaller butterfly, furnishes a dainty morsel for bird palates. It would soon be exterminated were it not for the fact that it so closely resembles in color and markings the milkweed-butterfly, to which 
it is not closely related in structure or in mode of growth (Figs. 54 and 55 ).

Such imitations of other animals less likely to suffer from enemies are common throughout the animal kingdom. In these cases, neither the mimic nor the animal mimicked is supposed to act consciously. No intelligence on the part of the animal itself is shown by such mimicry, for even if it intelligently wished to change its color, no butterfly could do so.

The theory which is now generally believed by scientists to account for these protective devices and the thousands of others that have been observed may be briefly illustrated by considering the family history of the moth whose wings resemble birch-bark.

Natural Selection. It is supposed that the earlier members of this family did not have the outer wings so marked, but that from a brood of caterpillars there hatched moths like the parent moths, yet varying to some extent on account of unknown causes. Some of these varying moths had markings on the outer wings which made them resemble in some slight degree the birch-tree on which they were accustomed to alight. It is evident that these protected moths would be less likely to be eaten than those not resembling the birchtree; hence they would be preserved to deposit eggs, while their less fortunate brothers and sisters would be eaten. The next brood of moths, resembling their parents as they must, would be likely to include a greater number of protected individuals, and probably some even better protected than their parents. Those best protected would be allowed to produce offspring, while the less favored would be destroyed. In this way after many generations the protective resemblance becomes more and more pronounced. This process has been called "natural selection". It is thought to explain many of the changes which have taken place in the history of both animals and plants. It is easy to see that there is really no rational selection on the 
part of the animals themselves. The name was given because the process resembled somewhat the process by which bird-fanciers obtain different varieties of pigeons by "selecting" birds with peculiar markings for breeding purposes, or by which gardeners obtain new varieties of flowers by continually "selecting" the few having desirable peculiarities and obtaining seeds from these for the production of more and more desirable plants. In natural selection there is no birdfancier and no gardener. On this account the process

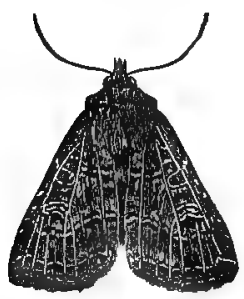

FIG. 56a.-Moth at Rest.

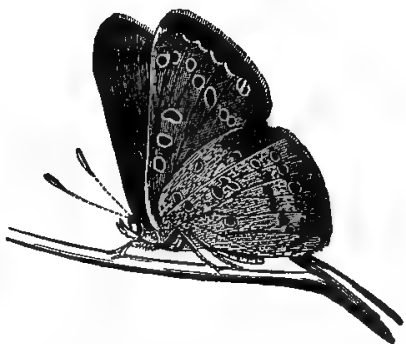

FIG. 56b. -Butterfly at Rest.

has been spoken of as the "survival of the fittest". In this case the "fittest " is the individual best adapted to his surroundings and best protected in every way. In these days the student of animals or plants is constantly on the watch for new illustrations of adaptation to surroundings on the part of living organisms.

Questions. r. How do moths differ from butterflies in structure and in habits?

2. What are the differences between complete and incomplete metamorphosis?

3. How much can a butterfly see?

4. How much can a caterpillar see ?

5. Do either caterpillar or butterfly have a sense of smell ? of hearing?

6. What are some enemies of butterflies? 
7. How are butterflies protected?

8. Does the pupa of a butterfiy breathe?

9. Do you know any common animals which are protected by their color?

Topics for Reports. The Silk-worm. The Gypsymoth. The Clothes-moth. The Life-history of Cecropia. The Metamorphosis of Lepidoptera. How to Destroy the Most Injurious Lepidoptera. Insects as Food.

\section{VOCABULARY.}

A'nus (Lat, anus, a ring), the opening of the digestive canal opposite the mouth.

Chrys'a lis (Gr. chrysos, gold), the naked pupa of a butterfly.

Cos tal (Lat. costa, a rib), the anterior part of a wing.

Co coon' (Lat. concha, a sheli), the silken covering of a pupa.

Gan'gli on (Gr. ganglion, a tumor), a nerve-mass.

Haus tel'late (Lat. hausirum, a water-drawing machine), having mouth-parts fitted for sucking.

I ma'go (Lat. imago, likeness), the adult insect.

Lar'va (Lat. larva, a mask), the stage of metamorphosis immedi. atelv succeeding the egg.
Man di bu late (Lat. mando, chew), having mouth-parts fitted for biting.

No'tum (Gr. notos, back), the dorsal surface.

Pri'ma ry wings (Lat. primus,. first), the first pair of wings.

Pro bos'cis (Gr. pro, before, and bosko, feed, the sucking tongue of a butterfly.

Pu pa (Lat. pupa, a doll), the stage of metamorphosis after the larva.

Sec'on da ry wings (Lat. secundus), the second pair of wings.

Vein (Lat. vena, a blood-vessel), one of the vein-like ribs of an insect's wing.

Vein'ules, branches of veins. 


\section{CHAPTER VI. \\ SOME INSECTS CLASSIFIED.}

The Bluebottle Fly. Expose a piece of fresh meat in a sunny place for a short time and these flies will collect on it. Capture some of the flies and observe them carefully.

How does the fly feed? You can study the mode of feeding of the common house-fly by fastening a piece of sugar to a slide and placing it under a microscope in a place where flies are plentiful.

What kind of food does a common house-fly prefer? How do you know?

Devise an experiment for determining what kind of food the house-fly particularly likes. In experimenting with foods try sugar, honey, salt, pepper, water, and other substances.

Does sight or smell seem to guide the fly to its food?

How does a low temperature affect flies? How do you know?

How do the flies make their buzzing ?

Keep a few bluebottle flies under a tumbler with a bit of meat until eggs are deposited. Remove the flies and watch the development of the eggs. Does the fly have complete or incomplete metamorphosis ?

How many wings has the fly?

How many segments has the fly's abdomen?

See if you can find a winglet behind the wing.

Using a lens, do you find a pair of balancers behind wing and winglet?

Is one of the segments of the thorax larger than the rest? 
Do you find spiracles on either thorax or abdomen ?

Do you find eyes and ocelli?

Do you find antennæ?

Write resemblances and differences for fly and grasshopper.
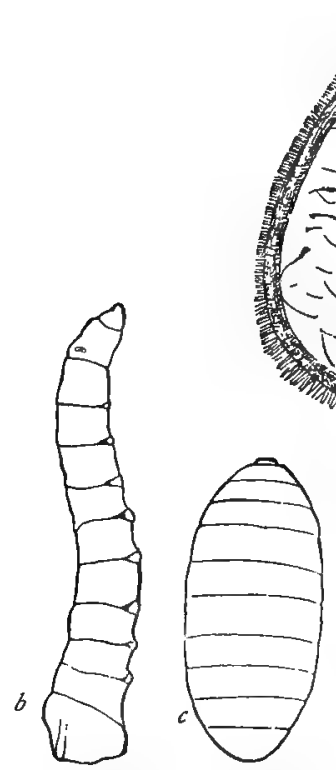

Fig. 57.-Larva and Pupa of the House-fly. $\quad b$, larva (magnified); c, pupa (magnified).

FI

FIG. 58.-Right Winglet of Bluebottle (magnified).

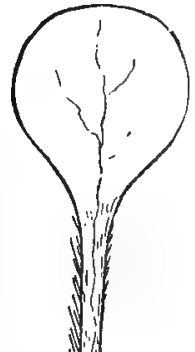

Summary of Drawings. (a) A fly as seen from above with the wings extended at right angles to the body $\times 5$.

(b) The larva and pupa of a fly $\times 5$.

(c) One wing $\times 5$.

(d) A balancer much enlarged.

(e) One antenna as seen with the microscope.

$(f)$ One leg and foot as seen with the microscope. 


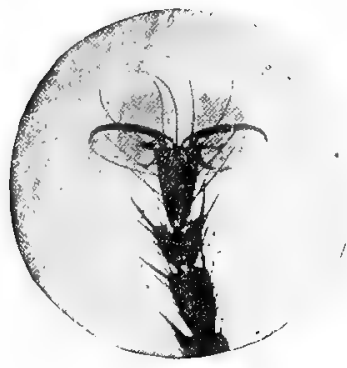

Fig. 60.-Portion of a Fly's Foot (magnified).

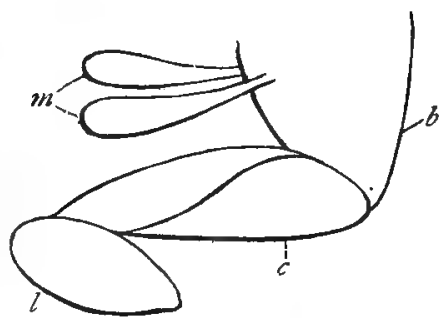

FIG. 6r.--Side View of Proboscis, partly opened. $b$, basal division; $c$, central division; $l$, labella; $m_{2}$ maxillary palpi.

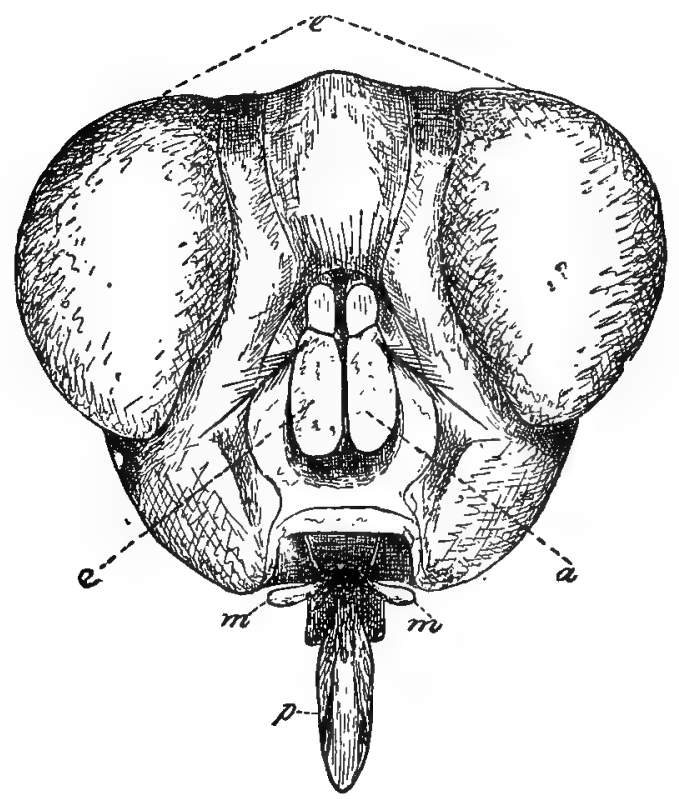

Fig. 62 Head of Bluebottle. $a$, antennæ; $c$, eyes; $m$, maxillæ; $p$, proboscis (magnified). 
(g) A foot highly magnified, showing the two claws at the end of the last segment and the sucking-disks by which the fly walks on a ceiling.

(h) The proboscis as seen with the microscope.

The Colorado Beetle. This beetle is often called the potato-bug or potato-beetle. Its destructive ravages are well known. A visit to a potato-field anywhere while the plants are growing will commonly provide the collector with an abundance of specimens in all stages of growth from the egg to the adult. Look for eggs on the under side of a leaf. The pupa stage is spent underground, and specimens are more difficult to find. Keep in formalin.

Examine a living beetle.

Notice how it eats, how it walks, and how it flies.

See if you can make out how its wings are folded.

How does the folding compare with the folding of the wings of a grasshopper?

Notice the eggs and the various stages of growth.

How many segments has the beetle's abdomen?

Of how many segments is each foot composed?

Examine a dead specimen with care and write resemblances and differences for beetle and grasshopper.

The Dragon-fly. Near fresh-water ponds and streams adult dragon-flies may be easily caught. The larvæ are usually plentiful where decaying leaves furnish food for the small animals on which they live. The imago may be mounted like a butterfly and then examined.

How many wings?

Are the wings folded?

Are the wings alike?

How does the veining compare with that of a fly's wing ?

Is the head easily movable?

How does it compare with the other insects you have studied in regard to the size of its eyes?

Has it ocelli? 
How do the mouth-parts compare with those of a butterfly? with those of a grasshopper?

Do you find toothed mandibles?

Are the segments of the thorax of equal size?

Are the legs strong or weak?

How does the abdomen compare with that of the grasshopper?

How many segments has the abdomen?

Do you find spiracles?

Examine one of the larvæ and tell how it differs from the imago.

Examine with particular care the mouth of one of the larvæ.

Summary of Drawings. (a) The imago as seen from above $\times 2$.

(b) One antenna, magnified (microscope).

(c) Side view of mask of larva, magnified (microscope).

(d) Side view of larva $\times 3$.

Mud-wasps can be easily collected in almost any locality. Obtain specimens and write resemblances and differences for wasp and beetle.

Squash-bug. Write resemblances for squash-bug and potato-beetle.

Resemblances. The number of insects is so great that it is practically impossible for one person to learn their names, to say nothing of being able to know their habits and structure.

When, however, one has become familiar with only a limited number of forms, certain resemblances thrust themselves upon the attention. These points of likeness are of great assistance in extending our acquaintance, for when we know one insect well we have some knowledge which applies to all. If we hear of a new insect we at once suppose that it has those peculiarities which we have found common to all insects we know, and in so supposing we are not likely to be mistaken. 


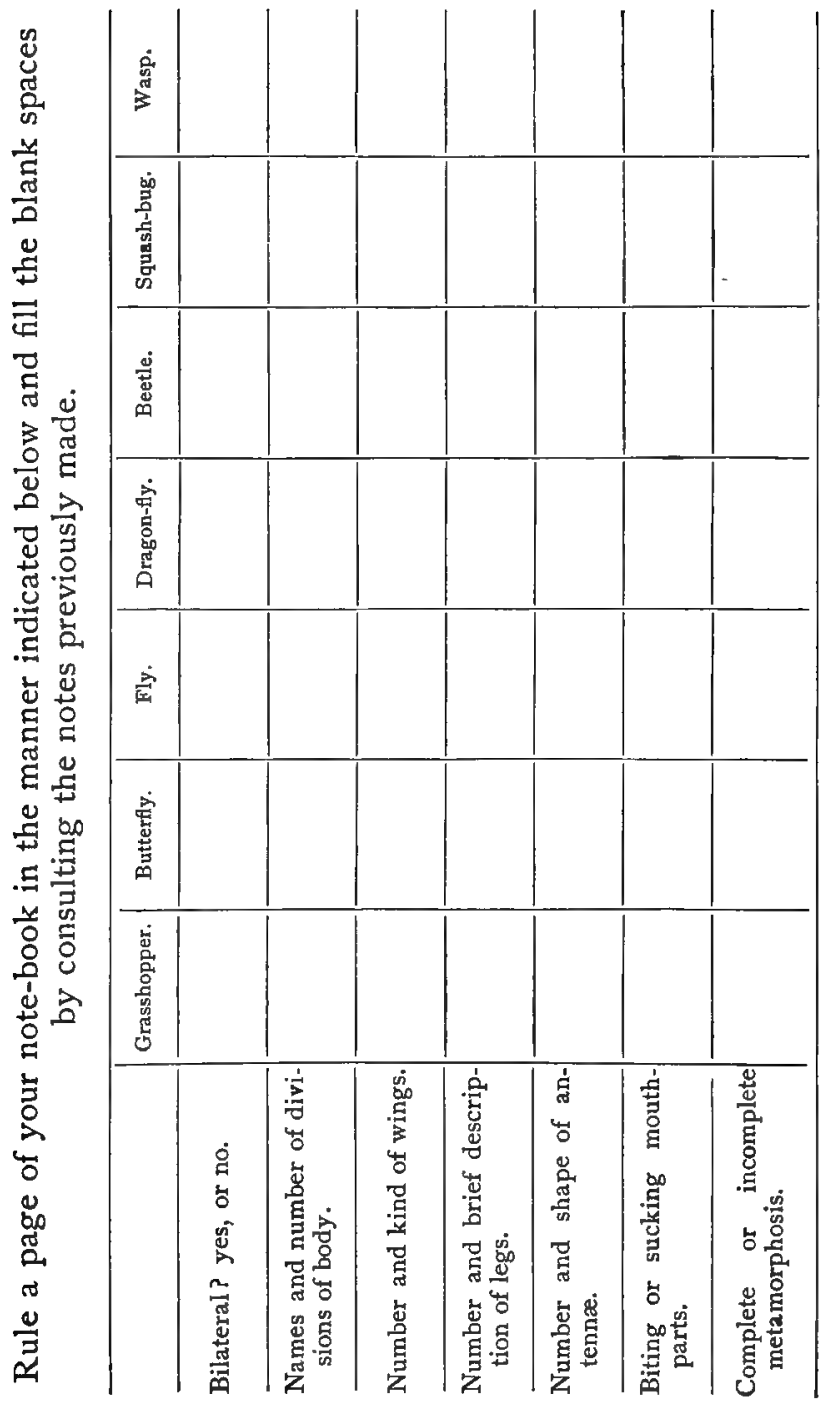


By comparing the notes we have already made we find that the insects so far studied have bilateral symmetry, jointed bodies, and jointed appendages, as legs and antennæ. They have three parts to the body; head, thorax, and abdomen. All have six jointed legs, and in the adult stage one or both sexes are usually provided with wings. Commonly two pairs of wings and a pair of compound eyes are present.

An examination of the internal structure of insects shows a series of ganglia connected by nerves situated along the ventral portion of the body. Above this is found the digestive cavity, consisting of a tube more or less branched extending lengthwise of the body, from the mouth to the anus. Near the dorsal part of the body is found a large blood-vessel which performs the function of a heart.

Breathing is carried on by means of spiracles connected with trachex. Naturalists have agreed to call animals having these characteristics "Insecta".

Differences. But the class Insecta contains so many individuals that we readily see the necessity of classifying them in some way. The divisions of classes are called orders. If we can divide the class Insecta into orders we make our future study more systematic and more satisfactory in many ways. Such a classification must depend on differences as well as resemblances. If we should study the mouth-parts alone of the insects we have already examined, we could easily put them into two orders or subclasses, one comprising those insects which have biting mouth-parts and the other those which have sucking mouth-parts. This division is sometimes used, but for our purpose it will be better to find some differences which will give us a greater number of orders, and so greater convenience.

A mode of separation based on peculiarities of the wings has been much used, and the common names for some of the orders as now most often written attempt to describe peculiarities of wing-structure. 
But this scheme of classification seems too artificial, that is, too much like the classification of inanimate things like tables or chairs, which may be arranged for convenience into classes according to use or shape.

The course of development from egg to adult is also an important factor in classifying living things, because it is thought to show better than anything else the natural relations or affinities, or we might say the blood-relations of animals: hence in classifying insects the matter of metamorphosis must be considered. In a superficial way we might divide insects into those having complete and those having incomplete metamorphosis, or into those having terrestrial larvæ and those having aquatic larvæ; but more careful study shows that these differences alone are not sufficient for a clear and systematic classification, nor do they, alone, indicate relation by descent. In fact, it has been found that with the best of effort in the matter of classification, so many intermediate forms occur that a series of individuals rather than a few orders result.

Still convenience demands a classification of some kind. Taking into consideration as many differences as possible, and ignoring some of the less obvious peculiarities, we may include all insects in nine orders:

Name.

Thysanura.

Pseudoneuroptera.

Orthoptera.

Hemiptera.

Neuroptera.

Coleoptera.

Diptera.

Lepidoptera.

Hymenoptera.
Typical Insect.

Springtails.

Dragon-fly.

Grasshopper.

Squash-bug.

Caddis-fly.

Colorado beetle.

House-fly.

Butterfly.

Bee.

Characteristics of the Orders. We give below the characteristics of these orders, noting chiefly the facts 
concerning wings, mouth-parts, and metamorphosis. There are, of course, many insects which do not fall easily into one of the orders as we have defined them, but it must be remembered that no classification of living things can be made to include all individuals. Some authors make a greater number of orders of Insecta, but the list here given is thought to conform to the best usage of writers on natural history.

Thysanura. These are small wingless insects with biting mouth-parts and incomplete metamorphosis.

The Pseudoneuroptera have two pairs of wings, very nearly alike in most cases. Their wings are very thin and transparent and closely veined and not capable of being folded. The mouth-parts are fitted for biting and the metamorphosis is incomplete.

The Orthoptera commonly have two pairs of wings, the under wings being folded like a fan, and protected by the outer pair. The jaws are strong and fitted for biting, and the metamorphosis is incomplete.

The Hemiptera, though sometimes wingless, have more often two pairs of wings. In some hemiptera the outer wings overlap on the back, the overlapping half of each wing being thin and membranous, hence the name. The mouth-parts are fitted for sucking, being prolonged into a beak used for piercing. They have incomplete metamorphosis.

The Neuroptera resemble the pseudoneuroptera in wings and mouth-parts and have complete metamorphosis.

The Coleoptera have hard outer wings called elytra which protect the inner, gauzy wings, which are folded both lengthwise and crosswise. The mouth-parts are fitted for biting and the metamorphosis is complete.

The Diptera have only two wings. The mouthparts are fitted for sucking and the metamorphosis is complete.

The Lepidoptera have four wings covered with scales. The wings do not fold. The mouth is fitted 
for sucking, having a long proboscis formed of the two maxillæ. The metamorphosis is complete.

The Hymenoptera have four membranous wings with few cross-veins, the fore and hind wings being commonly hooked together for flight. The mouthparts are fitted for both sucking and biting and the metamorphosis is complete.

Names of Insects. Animals, like plants, are designated in scientific works by two names, the first the name of the genus, and the second the name of the species. Thus, Danais archippus means that the butterfly bearing that name belongs to the genus Danais and the species archippus. We also distinguish men by using two names. Stuyvesant, Peter, as found in a directory, means that the man in question belongs to the family Stuyvesant, and that he is the particular member of that family known as Peter.

Questions. How does the grasshopper differ from all the other insects studied?

How does the butterfly differ from the beetle? from the dragon-fly? from the other insects studied?

How does the fly differ from the other insects?

How does the beetle differ from the other insects?

How does the squash-bug differ from the beetle? from the grasshopper.

How does the wasp differ from the fly? from the other insects studied?

How does the dragon-fly differ from the wasp ? from the butterfly?

In what respects do all the insects studied resemble one another?

Topics for Reports. House-flies. Insects in Brooks. Agricultural Ants. Insects in Ponds. Earwigs. The Cicada. Insects in Houses. Insects on Apple-trees. How to Prepare Insects for Cabinets. How to Kill Injurious Insects. Length of Life among Insects. Insect Friends. Sounds Made by Insects. 


\section{VOCABULARY.}

Bal'an cer (Lat. $b i$, two, and $\operatorname{lan} x$, dish), one of the poisers of a dipterous insect.

Col e op'te ra (Gr. koleos, sheath, and pteron, wing), beetles.

Dip'te ra (Gr. di, two, and pteron), two-winged insects.

El'y tron, pl. elytra (Gr. elytron, a shield), is thickened fore-wing of an insect.

Ge'nus, pl. genera (Lat. genus, a race), a group of animals or plants commonly made up of two or more species.

Hal'ter, pl. halteres (Gr. halteres, jumping weights), a balancer of one of the diptera.

Hem ip'te ra (Gr. hemi, half, and pteron), an order of insects including the true bugs.

Hy men op'te ra (Gr. hymen, a membrane, and pteron), an order of insects including bees and wasps.

In sec'ta (Lat. prefix in, and seco, to cut), a class of Arthropoda including all true insects.
Lep i dop'te ra (Gr. Lepis, a scale, and pteron), an order of inse including butterflies and mot

Neur op'te ra (Gr. neuron, ner and pteron), the name of an order of insects.

Or'der (Lat. ordo, order), one of the divisions into which classes of plants or animals are arranged.

Or thop'te ra (Gr. orthos, straight, and pteron), an order of insects including grasshoppers.

Pseu do neur op'te ra (Gr. pseudos, false, and neuroptera), the name of an order of insects differing from neuroptera in having incomplete metamorphosis.

Spe'cies (Lat. species, outward appearance), a subdivision of a genus.

Thy sa nu'ra (Gr. thysanos, fringe, and oura, tail), the name of an order of small insects.

Wing'let, a small winglike fold behind the anterior wing in the Diptera. 


\section{CHAPTER VII.}

\section{A CHAPTER OF LIFE-HISTORIES.}

The Milkweed-butterfly. In speaking of protective coloring we have already mentioned the large and beautiful butterfly commonly known as the milkweedbutterfly. It is known to scientists as the Danais arclippus or sometimes as the Anosin plexippus. On account of its large size, great beauty, and very general distribution, it has been much studied and its life-history is well known.

The female butterfly deposits her eggs one by one on the under side of milkweed-leaves. These eggs when examined with
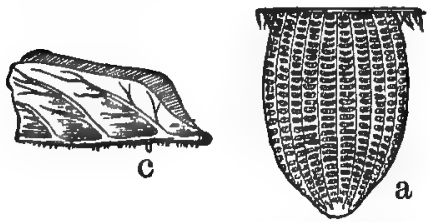

FIG. 63.-Eggs of Milkweed-butterfly. $a$, single egg, magnified; $c$, eggs on leaf, one half natural size. After Riley. th $\mathrm{e}$ microscope a $\mathrm{r}$ seen to be very regularly carved in a beautiful and delicate pattern. The shape of the egg is shown in Fig. 63.

In a few days a little black-headed caterpillar, perhaps a tenth of an inch long, emerges from the egg, eats its empty shell for breakfast, and dines upon the milkweed-leaf, on which it continues to feed for several weeks. At the end of one week, having eaten so much and grown so fast that its skin can no longer hold its body, it spins a bit of silk upon the leaf, waits until its coat splits down the back and then crawls out of the 
slit thus made, a larger and handsomer caterpillar. It moults in this way twice more, and at last looks like Fig. 64, having a pair of horns at each end of its body and being striped with black, white, and yellow.

It will be noticed that its first three pairs of legs are jointed and furnished with claws. The other legs, ten in number, are merely fleshy prolongations of the skin, provided with suckers or hooks to aid in crawling. These are called pro-legs, to distinguish them from the three pairs of jointed legs common to all Insecta. Its

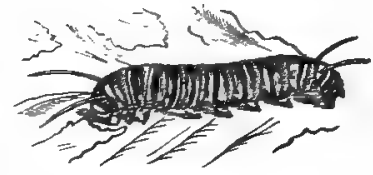

FIG. 64, - Larva of Milkweedbutterfly; one half natural size. After Riley. mouth is provided with strong mandibles, and its digesting power is enormous. The caterpillar has now reached a length of two inches. After a little time it again becomes restless, leaves the plant on which it has so far lived, and lodges on a neighboring fence or stump. Here it spins a little silk, entangles its hind legs in the threads thus produced, and hangs head dnwnward for a day and a night. Its skin then splits along the back and the caterpillar performs the difficult feat of crawling entirely out of its old covering without the use of legs or mandibles, for these

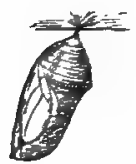

FIG. 65.-Pupa rf Milkweedbutterfly, one half natural size. After Riley. disappear with the old skin. The little spike at the end of its tail is fastened into the web of silk, and its body suspended thereby for a period of rest. The skin hardens and the rich ornamentation of green, black, and gold appears. We do not wonder that it is called a chrysalis (Fig. 65).

There is now no mouth for feeding, for the mouth-parts are undergoing a wonderful change just beneath the skin. The maxillæ elongate to form a proboscis, the wings appear and 
may be seen undeveloped within the chrysalis, as may also the antennæ, the legs, the segments of the thorax and abdomen, and even the spiracles. At this time the young butterfly must live by using the stored-up energy developed by its enormous appetite in the larval stage. The change now going on is termed pupation.

Again moulting occurs, and the imago emerges. At first it is soft and flabby, but the blood pumped into the baggy wings quickly distends them and they dry and harden in the sunlight. The body soon attains its full strength and the insect flies away to enjoy a life entirely different from its previous phases of existence. Now it rejoices in two pairs of large and strong wings covered with beautiful scales arranged in regular patterns. It sucks honey from flowers by means of its long coiled proboscis. This interesting piece of machinery has already been described. It is doubtful if this magnificent aerial creature, leisurely floating in mid-air, or bravely buffeting the winds, and sometimes sipping a bit of nectar, would recognize one of its brothers or sisters in either its gormandizing larval stage or its inactive pupal condition. Indeed, the graceful mother seems neither to recognize nor to care for the offspring crawling from the eggs she deposits from day to day.

Our milkweed-butterfly lives much longer than most of her lepidoptera relatives while in the imago stage. She even migrates when autumn comes and with others of her kindred seeks a warmer climate for the winter. Some of those which do not migrate hide in sheltered crevices to emerge in the spring battered and frayed, but ready to deposit eggs for the new broods which are to people the air of the coming summer.

The Cricket. The common black cticket so often seen in the fields and about our gardens in the late summer and during the autumn is known as Gryllus abbreviatus. His pleasant chirp attracts us to an 
examination of his ways. Putting him under a tumbler over a flower-pot filled with earth, and feeding him with bits of apple or potato and sometimes a little clover, we may easily observe his movements. If we are looking at the male we must watch for the source of his cheerful music, for the males do the talking among crickets. We shall see, when the shrill sound is made, that the outer wings are raised a little and
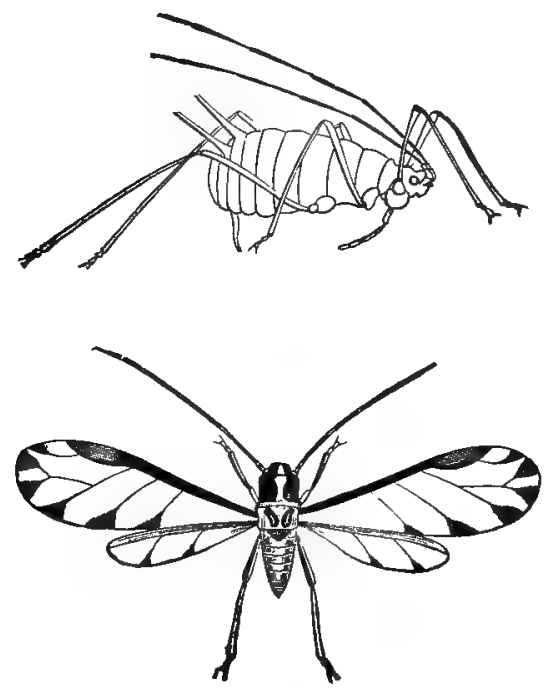

Frg. 66.-Female and Male Aphis.

moved rapidly from side to side. A careful examination shows on the inside of the membranous wing-cover a vein extending diagonally across the wing and furnished with teeth like those on the corner of a file. On the other wing-cover, near its inner margin, there is a hardened part which scrapes over the file, causing it to vibrate. The membranes of the wing re-enforce the vibration. Thus its voice comes not from its throat 
but from its back. In this respect it resembles many other insects.

If we are looking at the female cricket we are struck with the length and size of the ovipositors, which consist of a pair of grooved appendages which fit together to form a long tube with a sharpened point. In the autumn the cricket bores a hole in the ground with these sharp points and deposits her eggs, where they remain through the winter. In the spring the warmth of the sun causes them to hatch and the little crickets appear. Here we have something very different from the hatching of the milkweed-butterfly's egg. No caterpillar appears here, but a tiny cricket, much like its mother, but lacking wings. These little crickets moult from time to time, at each moult growing more like their parents, until about midsummer, when they attain their full size. Before winter they die.

The Aphis. Plant-lice are very familiar pests, whose ravages on the leaves of rose-bushes are well known. There are many kinds of these little destroyers inhabiting as many kinds of plants. They are called Aphides, any one insect being an Aphis.

A single aphis with its beak stuck into the juicy part of a leaf, from which it never moves unless forced to do so, constantly filling its stomach with sap, seems, indeed, a mere glutton, but the whole brood of aphides when watched for a summer are a wonder-working community. The laboratory for the study of these strange creatures is ready-made everywhere. Wherever rose-leaves grow, a lens will reveal the happenings we are about to relate.

In the month of October in temperate climates the wingless female deposits her eggs about the buds of rose-bushes, so that when these develop into leaves and branches in the coming spring the young aphis may have at hand a bountiful supply of rich food. Here the egg stays until the warm sun of March or April assists in the process of hatching. 
There hatch from these eggs a brood of females, very small at first, but, after several moultings, as large as their mothers, and resembling them in many ways. No males are hatched from these winter eggs. The leaf soon becomes covered with a swarm of female insects. Indeed, there are no fathers in these armies of pigmies. They produce no eggs, but proceed to fasten their beaks in a juicy spot and eat and reproduce in a most marvelous manner.

From the abdomens of these strange mothers there issues day after day a numberless horde of children like themselves. These children grow from the mother as buds grow on plants, and then break away to lead an independent life. Each tiny bud in a few days becomes a mother in the same way, and shortly, from a single egg, thousands of wingless mothers sit side by side, sucking sap and budding out young with remarkable speed. If a man should live a hundred years and count at the rate of one a second, he could not begin to count in his hundred years the progeny of a single aphis for a month.

Now and then winged forms appear, and sometimes an aphis goes through something like a larval and pupal stage, while the colony keeps on increasing with incredible rapidity by the budding of generation after generation. This reproduction without males is called furthenogenesis.

Toward autumn winged males are produced, and again the cycle of existence is renewed.

In studying the life-history of the aphis one should notice the relations existing between ants and aphides. As the aphis sucks the sweet sap from its shrub it obtains an excess of sugar; that is, in order to get all the muscle-forming fod it requires it must eat more sugar than it needs. This excess of sugar is known as honey-dew, and it often covers the leaves with a stucky film. It comes from two projections on the end of the abdomen of the aphis. This honey-dew, not 
needed by the aphis, is relished by other insects, notably the ants, which may be seen stroking the projections from which the honey-dew exudes and eagerly eating the sweet fluid.

So much do the ants appreciate this honey-dew that they take great pains to care for their friends the aphides, in many cases herding them as men herd cows, and sometimes carrying their attentions so far as to take the winter eggs of their cows into their own houses to keep them from frost and enemies. With returning spring these eggs are taken out again and placed upon their proper food-plants to hatch in the warmth of the sun and produce another colony of aphides.

The Ichneumon-fly. Teachers of Zoölogy frequently have brought to them for identification and explanation a caterpillar, having his back covered with a mass of silken cocoons. If we wait for the cocoons to hatch we may see coming from each a black fourwinged insect from one eighth to one fourth of an inch in length. The female of this insect, when mature, deposits great numbers of small eggs directly under the skin of a living caterpillar. These eggs soon hatch into small grubs or maggots which live on the fat of their host, not interfering with his digestive apparatus or other vital organs. After a time the full-grown larvæ bore holes through the caterpillar's skin, come out of their living prison and spin cocoons, fastening each to the caterpillar's back by a thread of silk. In these cocoons the pupa stage is passed and the adult insect gnaws his way out to begin another cycle. These insects are often called microgaster-flies. They belong to the order Hymenoptera (Fig. 67).

The Sand-wasp. Still another method of preparing fresh meat for the young has been invented by some of the wasps. These wasps catch a caterpillar, a spider, or some other insect, and sting him in such a way in the thoracic ganglia that the victim becomes 
paralyzed but is not killed. The wasp then drags her prey into her hole, and deposits an egg on the motionless but living insect, apparently knowing that death will not occur until her egg has become a larva and requires food. When the larva appears he finds his food still living, and makes it last until he is ready to assume the pupal condition. This is a remarkable insect adaptation for the preservation of food.

There are many of these wasps. Some of them live in holes in the ground, which they stop up and conceal
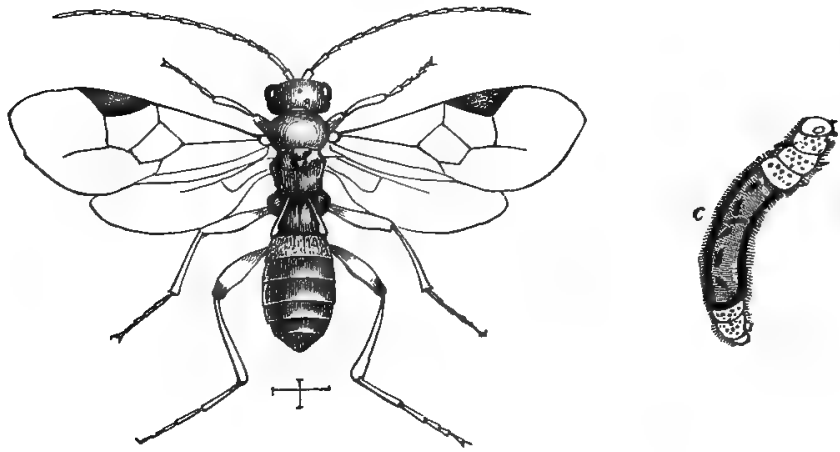

FIG. 67.-A Microgaster Fly (magnified). c, larva of a microgaster in the caterpillar of a cabbage-butterfly.

in very ingenious ways after the egg and its provender have been stored away.

Others build their nests or cells of mud, enclosing the young and its food in earthen jars.

A full-grown mud-wasp may be kept in confinement for a time and fed on sugar and water. Her membranous wings, four in number, are folded over her back when at rest, but during flight they are spread out and the fore and hind wings are fastened together in such a way by hooks and grooves that they appear like a single pair. 
The ovipositor differs from that organ as we have seen it in the cricket and grasshopper in having, in addition to the grooved sheath through which the eggs pass, a pair of lances which pierce the insect it wishes to paralyze or kill. The paralysis is probably caused by a bit of formic acid which is secreted by a small gland in the wasp's abdomen and injected into the body of her victim.

The sting, then, in this case as in the bee and other hymenoptera, is a modified ovipositor.

The care with which the wasp cleans its body and performs its toilet is worth noting. In fact, many things may be learned by watching one of these intelligent little workers.

The Dragon-fly. To study insects which spend a part of their life in the water an aquarium is helpful and pays well for the trouble it costs.

To study the young dragon-fly one should visit a pond or pool of fresh water, provided with a small net and a supply of fruit-jars. The young dragon-flies may be recognized by their flat square heads, their rudimentary wings, and their six strong legs. They frequent the bottom of the pool in which they live and their color protects them from observation, but careful watching will soon reveal their presence. One sweep of the net will sometimes bring several nymphs to the collector's jar. One must at the same time collect some aquatic plants to keep in his aquarium, and also a supply of small insects for dragon-fly food. A little mud from the pool with some submerged sticks and leaves will furnish insect-food for several days, after which a fresh supply should be provided. With a little sand in the bottom of a jar, a few growing water-plants, and a supply of dragon-fly nymphs of varying sizes, we are ready to learn something of the life-history of the mosquito-hawks, as dragon-flies are sometimes called.

While collecting the young, one is likely to see the adult females dipping the tip of the abdomen beneath 
the surface of the water in the act of depositing eggs. These eggs soon hatch into tiny nymphs, which live in the water, and, moulting from time to time, produce the various sizes found by the collector.

If we compel a few of these nymphs to go without food for a day and then feed them with insects, we shall be able to watch the use of the strange mask which hides the face, or perhaps we should say the mouth. This mask is really a very strange development of the so-called lower lip, the structure of which may be understood by examining one of the nymphs and comparing it with the accompanying sketches (Fig. 68). After all, it is not so much a mask as a

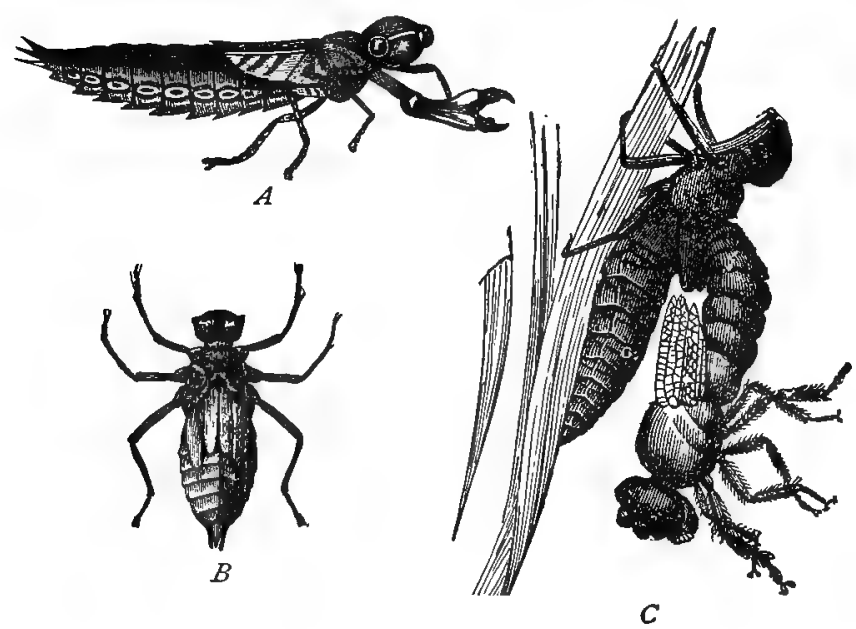

FIG. 68.-The Dragon-fly. $A$, larva; $B$, pupa; $C$, dragon fly emerg. ing from pupa-case.

formidable grasping organ capable of reaching suddenly forward, seizing an unsuspecting victim, and dragging him back to the hard mandibles. 
Breathing of a Dragon-fly Nymph. An insect living in the water must breathe, and it is interesting to observe how insects which have chosen an aquatic life have adapted their breathing-organs to the medium in which they live. The dragon-fly larva does not trouble himself to come to the surface for air, but simply takes his oxygen from the air dissolved in the water. The spiracles which would allow water as well as air to enter the breathing-tubes are closed and covered by the hard exo-skeleton, but the tracheæ or breath-

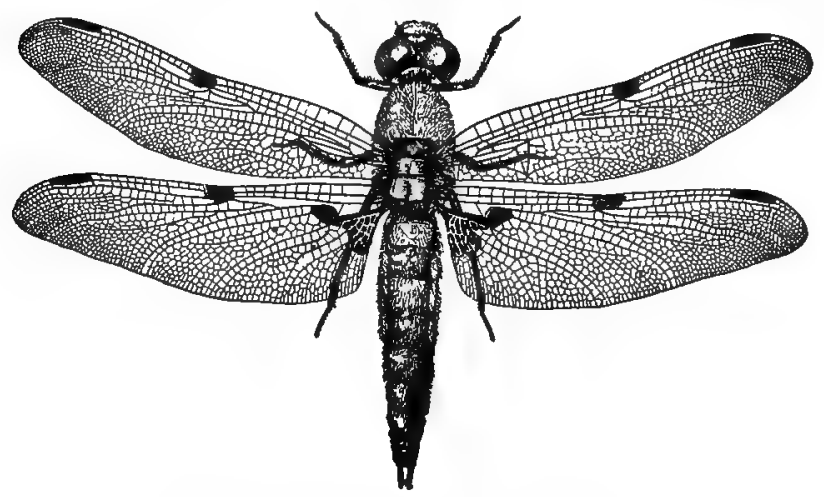

FIG. 69.-The Imago of a Dragon-fly.

ing-tubes, like those in the grasshopper, convey the air throughout the body. To get the air, the water is drawn in through the anal opening, where it comes in contact with some modified air-passages which have somewhat the function of gills. In these air-passages the carbon dioxide and other impurities await the opportunity to pass by osmosis to the water, while the oxygen penetrates through the membranes into the breathing-tubes. If a fine stream of bright-colored liquid be put near a nymph by means of a small pipette the currents produced by the breathing may be seen. 
Possibly some of the larger nymphs in the aquarium may crawl up a stick or other object and, fastening their feet firmly, await their final metamorphosis from aquatic to aerial life.

At this time the exo-skeleton of the nymph splits down the back and there emerges the beautiful creature we so often see hovering over the surface of streams and ponds. The two pairs of delicately veined wings
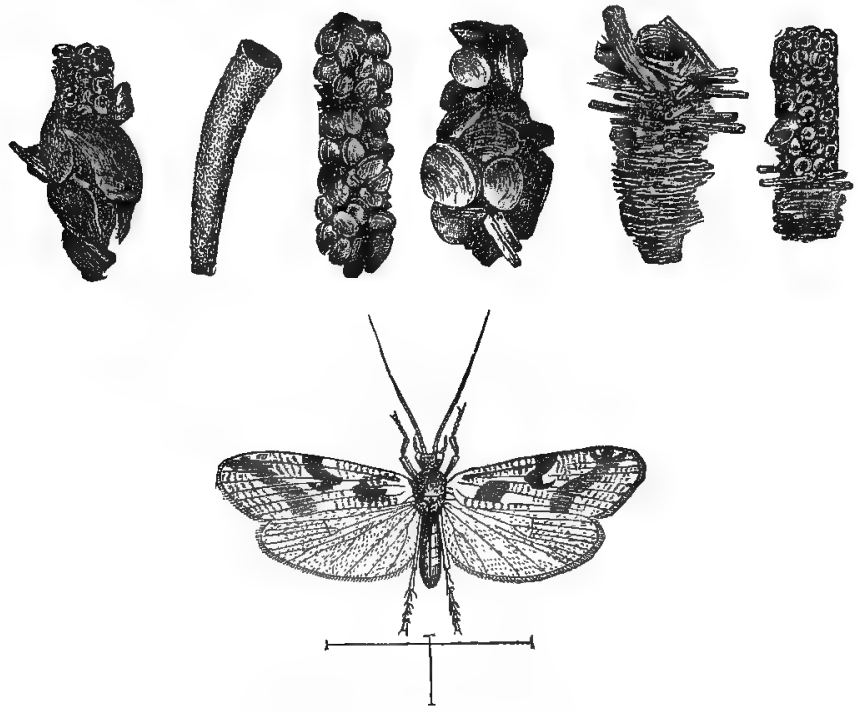

Fig. 70.-Caddis-fly, Adult and Larval Cases.

are never folded like those of the grasshopper or beetle, but remain extended even while the insect alights. The lower lip has lost its mask-like appendage, the mandibles are hard and toothed, the eyes are very large, the abdomen is long and tapering, the legs are small and bunched together for security in alighting. It is now a fine creature of wonderful agility and grace. Harmless to man and larger animals, it devours mos- 
quitoes and other small insects, catching them on the wing with hawk-like flight and precision of aim.

The dragon-flies belong to the pseudoneuroptera. By some they are put in a separate order, the odonata. Other Aquatic Insects. While collecting and observing the young dragon-flies one cannot help noticing the fact that many other insects spend a part
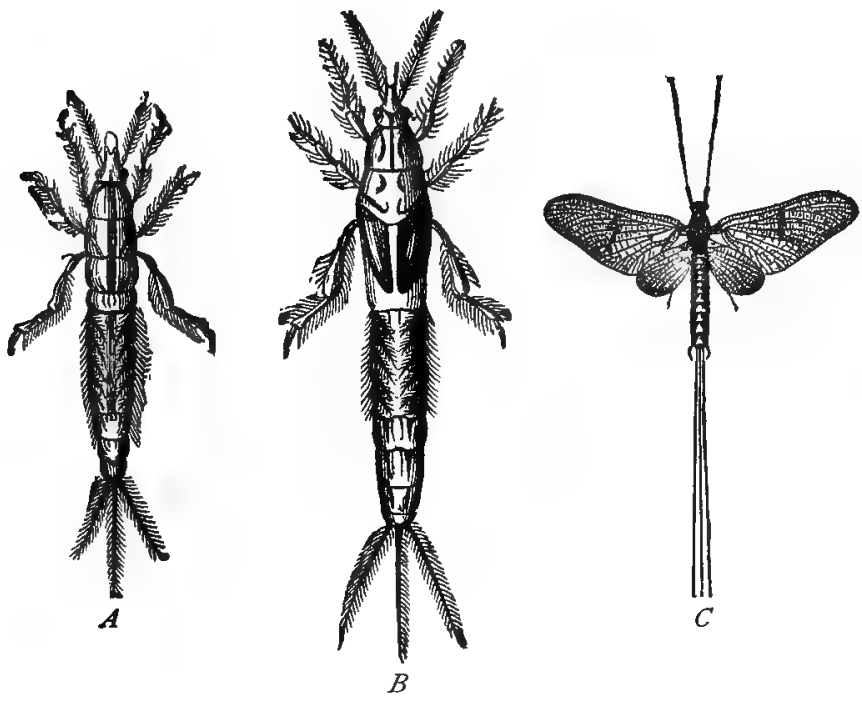

FIG. 7I.-The Growth of a May-fly. $A$, larva; $B$, pupa; $C$, imagn.

or the whole of their life in the water. It will be interesting to watch the young caddis-fies (Fig. 70), young may-fies (Fig. 7I), the adult water-boatman swimming on his back with his legs modified to form oars (Fig. 72), the ditycus or large water-beetle carrying a bubble of air under his elytra and feathering his oars as he dashes through the water (Fig. 73), and the giant water-bug with powerful piercing beak and 
mighty fore legs for holding his victims while sucking their life-blood (Fig. 74).

The Mosquito. Among aquatic insects the familiar mosquito or gnat deserves a paragraph. The female mosquito, which by the way is said to do all the biting
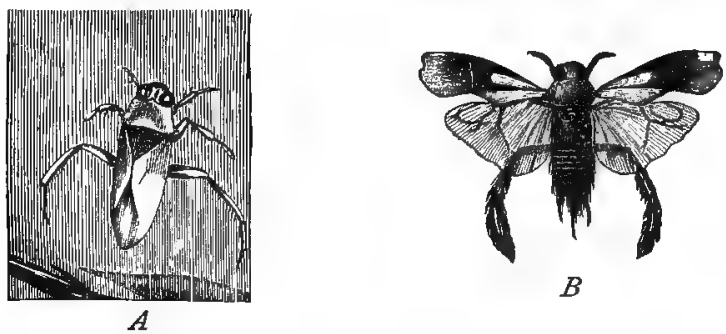

FIG. 72.-A Water-boatman. $A$, in the water; $B$, while flying.

and all the singing, leaves her eggs, sometimes two or three hundred in number, glued together in a sort of raft which floats upon the water (Fig. 75). In a few days the tiny larvæ open the under side of the eggs
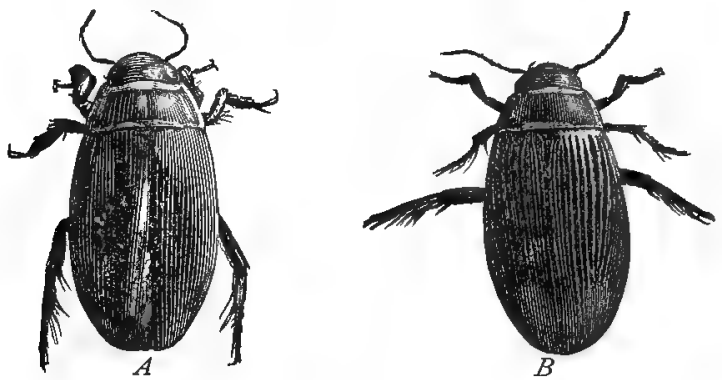

FIG. 73.-Dyticus Marginalis. $A$, male; $B$, female.

and descend into the water, where they swim rapidly about with a peculiar jerking motion. The large head is usually downward, always so while at rest near the surface of its pool. Just back of the head is a large 
joint commonly called the body, and back of that the smaller joints of the abdomen. The end of the tilil is

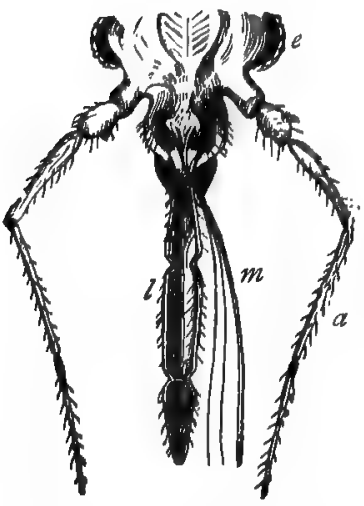

FIG. 74. -Mouth of a Bug. a, antennæ; l, labium; $m$, mandibles and maxilla; $\iota$, eye. double as shown in the figure. One projection is the insect's propeller, and the other its breathing-tube, which it is constantly using when it rest, opening or closing at will the tiny valve at its $c x-$ tremity. The mosquito larva, then, breathes air directly and does not take it from the water like the young dragonfly. Like its mother, the larva is bloodthirsty and always hungry. At the end of about two weeks, after moulting several times, the larva changes to a pupa, bending its head under its body as seen in the figure and losing its mouth altogether, but retaining its power of active movement. The breathing-tube at the end of its body disappcars and it now takes air by two tiny projections on its back. Finally, the pupa rises to the surface of the water and again moults, producing the adult mosquito, which uses its cast-off skin as a boat on which it floats until its wings are dry and it is ready to fly away. Should its frail boat capsize and wet its wings the mosquito would drown. It has been found that a little kerosene spread upon the water of stagnant pools will not only kill the egg-rafts as they float about but will also destroy the perfect insects as they emerge from their pupa-case boats.

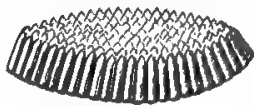

FIf; 75.-The Egg. raft of a Mosquito.

The imago now breathes, like other insects, by the spiracles along the sides of its body. It has but one 


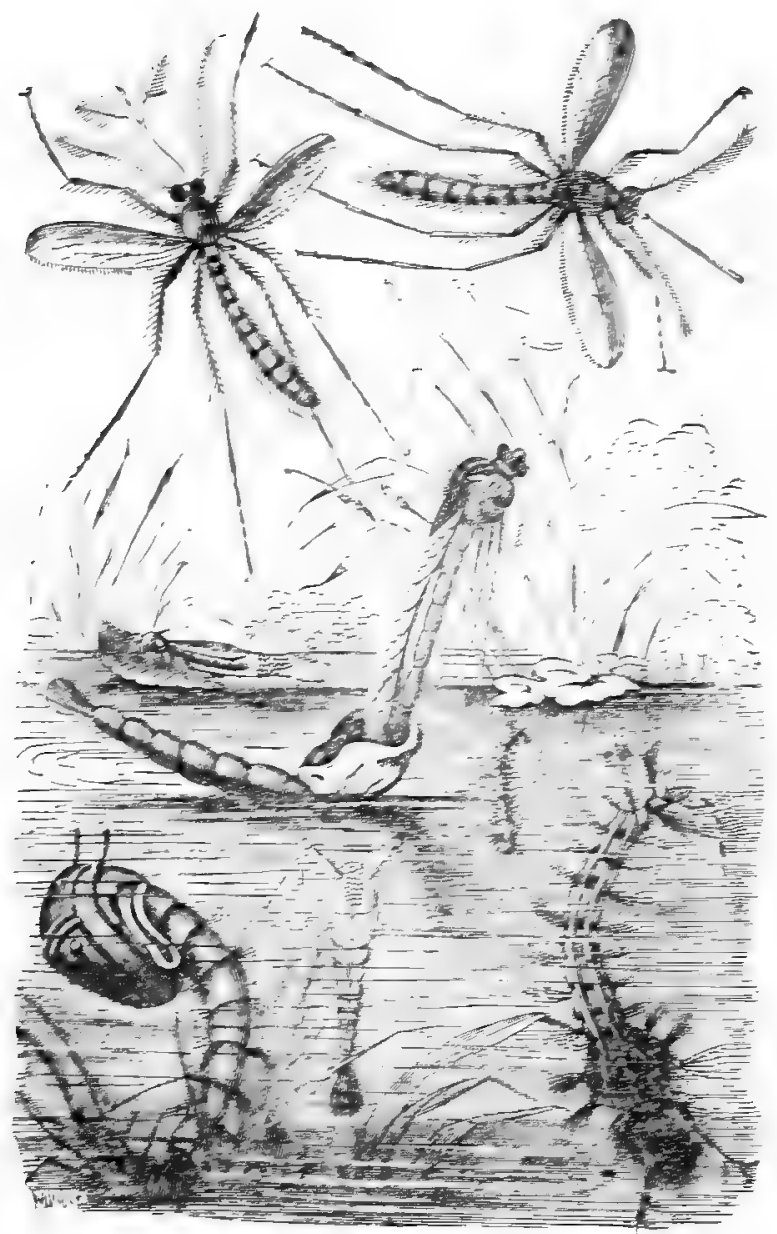

E:3. $-\because-T \div$ I I 
pair of wings, and its mouth-parts are fitted for sucking. The mouth of the male mosquito is adapted for

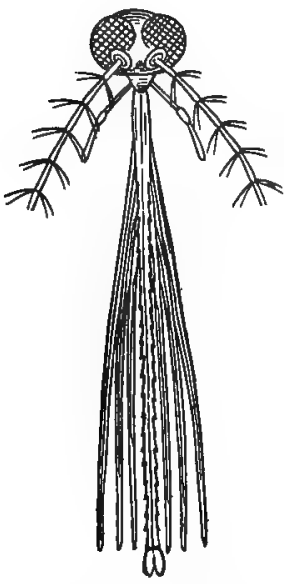

Fig. 77.-The Mouth of

a Female Mosquito. sucking honey from flowers and it leads a mild and peaceful life. The female mosquito, on the other hand, has, in addition to the proboscis for sucking blood, a number of sharp lances with which she pierces the skin of her victim. At the time of piercing she also injects an irritating fluid into the puncture (Fig. 77).

The music made by the mosquito is produced in two ways, first by the rapid movement of the wings, and second by the passage of air in and out of the spiracles. The humming thus made is thought to be heard by the male mosquito, whose ears consist of tufts of hairs on his antenna. These hairs are said to vibrate in unison with the tones made by the wings and spiracles of the female. Experiments seem to show that some varieties of mosquitoes are responsible for spreading both malaria and yellow fever.

A comparison of the life-histories here outlined gives one a notion of the great variety of modifications of a common plan of structure to compass different objects. How these modifications have come about in the progress of insect-life is one of the most interesting problems before the student of nature's ways. The change from a caterpillar with biting mouth-parts to a butterfly with his long proboscis gives a hint of the possibilities of evolutionary growth.

Questions. I. Have you observed closely the lifehistory of any insect? If so, what are some of the changes you have noticed? 
2. What advantages and what disadvantages must be experienced by a larva living in water?

Topics for Reports. The Life-history of a Beetle. A Life-history I have Observed.

\section{VOCABULARY.}

A phis, pl. aphides (Gr. apheides, lavish), a plant-louse.

Cad'dis-fly, a name given to an insect whose larva lives in the water and builds for itself a tubular case.

Gnat, a mosquito.

Ich neu'mon (Gr. ichneuo, to hint), a genus of insects belonging to the hymenoptera.

Mi cro gas'ter (Gr. mikrws, small, and gaster, stomacl " a small hymenopterous lly.
Mo squi'to (Lat. musca, a fly), a well-known dipterous insect.

Par then 0 gen'e sis (Gr. parthenos, a virgin, and gignomui, to be born), reproduction by means of unfertilized eggs.

Pro'leg, one of the fleshy abdominal legs of insect larva.

Pu pa'tion (Lat. pupa, a doll), the process of undergoing the pupal condition. 


\section{CHAPTER VIII.}

\section{SOME INSECT ADAPTATIONS.}

Structure and Habits. Fig. 78 shows the parts of the hinder leg of a cockroach, an insect whose legs are well adapted for running. Comparing this leg with the corresponding legs of a grasshopper, we find the same parts present but modified for jumping. Looking at the legs of a mole-cricket, we find again the same parts, but in this case altered for digging. Among the large water-bugs, which live by hunting, the legs are fitted for seizing and holding prey. In some of these bugs, a portion of the $1 \mathrm{e} \mathrm{g}$

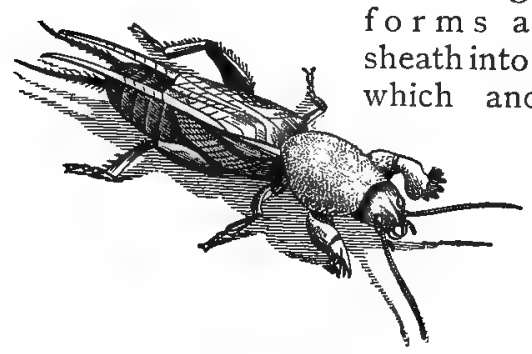

FIG. 79.-A Mole-cricket.

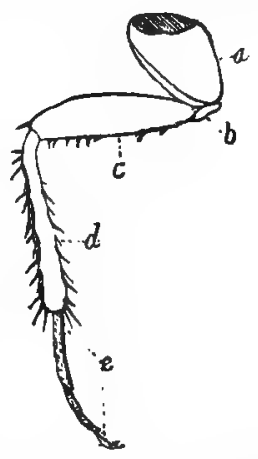

FIG. 78. - Leg of a Cockroach. $a$, coxa; $b$, trochanter; $c$, femur; $d$, tibia; $e$, tarsus.

(a)


even able to feather as they row along, yet here, as elsewhere, the plan of structure is the same as that
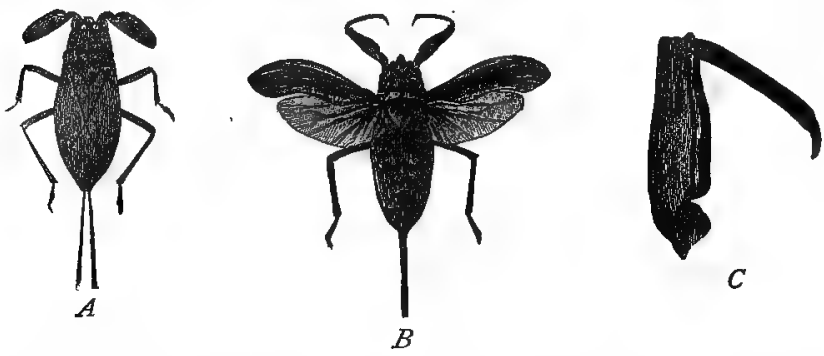

FIG. 80.-Fore Legs of a Water-bug. $B$, open; $A$, closed; $C$, enlarged to show sheath.

seen in the cockroach and grasshopper. Some butterflies of strong flight use their legs so little that their front legs are mere threads, yet they retain the marks
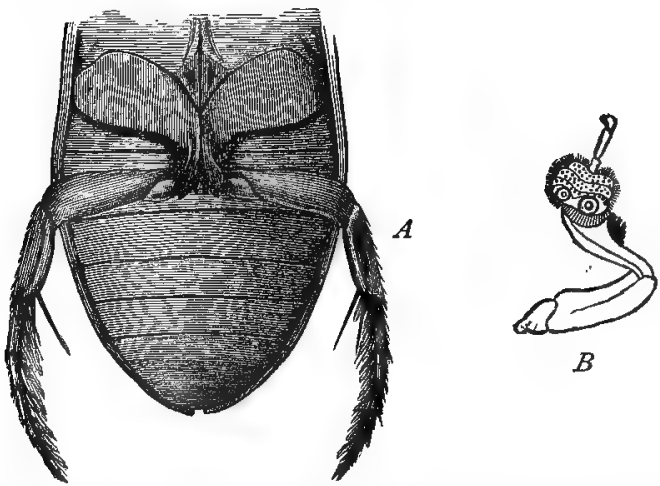

FIG. 81.-Legs of Dyticus. $A$, hind legs for swimming; $B$, fore leg with suckers.

of the same plan we have found in the other insects examined.

What is true of the legs is also true of other impor- 
tant organs. Devices for defence, for eluding enemies, and for procuring appropriate food among insects are everywhere seen to be varied modifi-

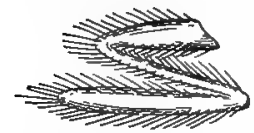

FIG. 82.-Fore Leg of a Butterfly. cations of the same organ or organs. In general such structures are found in any particular insect as best help it to preserve its life in the particular environment in which it lives. So much does the structure tell us about the mode of life, that we are often able to infer the habits of an insect which we have never seen alive from the study of dead specimens, and even from fossil remains.

\section{Changes of Organs Because of Changes of Habit.} That these variations of similar organs have arisen gradually, through changes of habit made necessary by changes in surroundings, is generally believed. At first sight the long delicate proboscis of the butterfly, the lapping tongue of the house-fly, the beak of the aphis, the hard, biting jaws of the beetle seem very different structures, but when we watch the caterpillar of the butterfly and the grub of the beetle with mouthparts so much alike at the start, and see that in one case the maxilla elongate into the coiled proboscis, and in the other the mouth-parts grow into the formidable and destructive biting-organs of a carnivorous beetle, we wonder less at the divergence than at the resemblance. We see, too, how it may have been possible for organs very unlike to have arisen from similar beginnings. The great variety seen in the breathing-organs of aquatic insects furnishes another illustration of the change of organs necessitated by a change of habit. From the fact that all aquatic insects breathe air by tracheæ at some period of their life it is believed that their ancestors, as well as the ancestors of insects having aquatic larvæ, were originally terrestrial. Either driven by enemies or lured by more abundant food, at some distant period, these insects 
began an aquatic life to which they became gradually adapted by a process similar to that by which the butterfly obtains his protective coloring. In fact the aquatic life is a protection, either from destructive enemies or from starvation.

Insect Communities. In speaking of the life-history of the aphides we mentioned the fact that ants sometimes keep these insects to provide them with honeydew. It is also true that some ants capture the pupæ of ants of other communities than their own and rear them as slaves. To obtain these pupæ wars are often waged, hence coöperation is necessary. Coöperation leads to life in communities and life in communities makes necessary a division of labor, so that we find nurses, foragers, soldiers, queens, and drones working together in the same community, all developed from eggs which are apparently just alike.

This production of seemingly different insects seems to be sometimes a matter of choice on the part of the rulers of the community, for it has been found that a worker grub, among bees, may be developed into a queen by the use of special food and the building of a royal chamber. This division of labor is best illustrated among bees, ants, and wasps.

Hive-bees. In a bee community there is one female called the queen who produces all the eggs. There are a small number of males called drones. All the rest of the inmates of the hive are workers. The workers are in reality immature females. They are provided with stings which are modified ovipositors. The wax is produced within the bodies of these workers and issues from between the segments of the abdomen, whence it is taken and skilfully built into the honeycomb, with which all are familiar. The honey, when taken from the nectaries of flowers, passes into a sort of crop, or honey-bag, where it undergoes changes which alter its flavor. It is then brought to the hive and stored in the cells of the honeycomb. The young 
bees hatch from the egg as larvæ, or maggots, in cells much like the honey-cells. In these cells they find a bountiful supply of food, known as bee-bread, which is composed of honey and pollen gathered by the workers. In these cells, too,
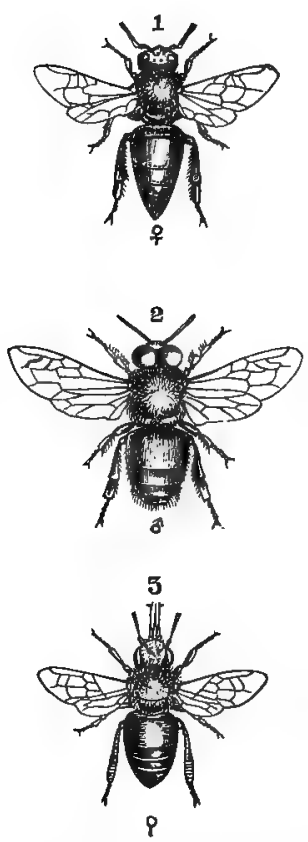

FIG. 83.-Hive-bees. I, female; 2, male; 3 , worker. the young bees pass through the stages of complete metamorphosis.

Insects and Plants. Besides the adaptations which fit insects to coöperate with one another, there are also equally wonderful adaptations of structure fitting insects to coöperate with plants to their mutual advantage. It is well known that plant-seeds, as well as the fertile eggs of animals, are produced only by the union of two kinds of cells, the male element being called the fertilizing cell. Among plants, pollen-cells grown on the stamens of flowers must fall upon the stigma and be conveyed thence to the ovary before seeds suitable for reproduction can be formed. In many cases the pollen from one flower must be conveyed to the stigma of another flower before fertilization can take place. This carrying of pollen from flower to flower is the work of insects which visit the flowers for the purpose of getting honey. On the visit, the pollen adheres to the hairs or other parts of the insect's body, and is rubbed off by the stigma of the next flower approached.

Each flower seems to depend on a particular insect whose proboscis just fits its own honey-cup. Thus, 
red clover cannot grow without the help of bumblebees. No more can bumblebees flourish without the honey prepared by the growing clover. When this partner-
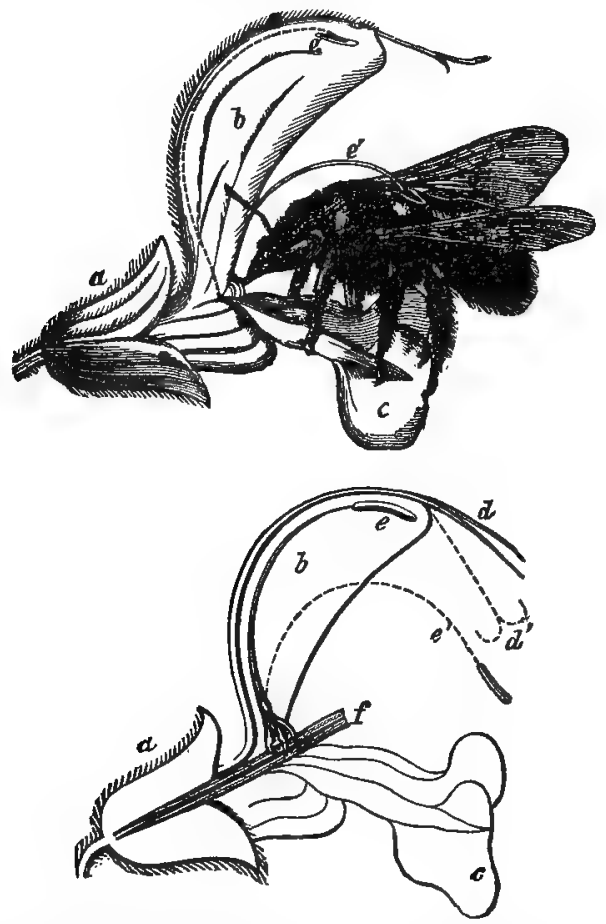

Frg. 84.-Fertilization of a Flower by an Insect. $u$, calyx; $b$, curved upper lip; $c$, under lip, on which the bee stands while sucking the honey; $d$, pistil; $d^{\prime}$, pistil at a later stage; $e$, stamen; $e^{\prime}$, stamen shedding the pollen from its anther on the back of the bee; $f$, bee's proboscis, with which it reaches the honey.

ship between the bee and the clover began we cannot say, but there is reason to believe that passing years, with their new generations of both bees and clover, only increase the dependence of each upon the other. 
If you examine a head of the common white clover, so abundant everywhere, you will see a part of the tiny flowers of which the head is composed standing erect and looking their best and prettiest. These are the flowers not yet visited by the bees; the dry and withered flowers hanging down near the stem have been fertilized, and each one now contains a pod in which the tiny clover-seeds are ripening.

Not only do we find the proboscis of an insect fitted in structure for the plant on which it habitually feeds, but we find the plants, also, ordering their ways to conform to the habits of their insect friends. Thus, stamens grow in such a way that they must dust their pollen on the insect as he reaches the honey-cup, while stigmas reach out in their growth to occupy at maturity a position in the pathway of the pollen-laden insect. Not only do stamens and stigmas seek the insect, but the petals call their friends by color-signs and point out by brilliant lines the direction of the honey-cup, while hostile barbs and pointed hairs below the cell of nectar prevent the approach of honey-loving ants and small insects not useful to the plant.

Questions. What structures would lead you to suspect that an insect leads an aerial life ? an aquatic life ? a terrestrial life?

Knowing an insect to be capable of strong flight, what might you reasonably predict concerning this insect's legs?

What might the mouth-parts of an insect indicate concerning its food?

What adaptations have you noticed in insects you have observed?

In what ways have you known insects to be especially protected from enemies?

Why do some insects commonly fly at night?

What insects have you observed at work at night?

What insect communities have you observed?

Have you seen insects carrying pollen? 


\section{CHAPTER IX.}

\section{A SPIDER'S ACTIVITIES.}

PLACE a living spider in a large glass jar and watch its movements for several days. Get a garden-spider if possible, and keep it well supplied with flies and other insects.

How does it take its food?

From what part of its body does its web issue ?

Do all spiders make the same kind of web?

Where have you seen spiders?

Where have you seen the eggs of spiders? How do they look?

Have you seen cast-off skins tangled in spiders' webs? If so does that indicate anything about the spider's mode of growth?

Can the spider smell? Test this point by bringing near the insect first a clean glass rod and then a rod dipped in a liquid having a strong odor.

Can the spider see? How far from her body can she see?

Using an alcoholic specimen, write resemblances and differences for spider and grasshopper.

How many divisions of the body?

Simple or compound eyes? How many?

How many legs?

How many segments in each leg?

Examine the feet with a microscope.

At the end of the mandibles find the poison-fangs.

Where are the spinnerets? How many do you find? 
Under the abdomen near the cephalothorax find two openings to the air-sacs or rudimentary lungs.

Summary of Drawings. above $\times 3$.

(a) A spider seen from

(b) A front view of the mandibles $\times 5$.

(c) A view of the top of the head showing the ocelli.

(d) A hind foot much enlarged.

The Spider's Activities. We have already considered the activities of the grasshopper, classifying these under six heads. We

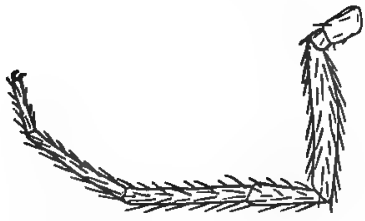

Fig. 85--A Spider's Leg. have spoken of these six kinds of activities as the six functions of living things. In the spider these activities are carried on by the aid of finely adjusted machinery which we can only, describe somewhat roughly here.

Taking Food. The devices by which spiders of different kinds procure their food are well worthy of study. Nearly all spiders are aided in this work by silken threads spun from their own bodies. In the lower part of the spider's abdomen there is a bag in which is secreted a glue-like substance which issues from the spider's body at will, and hardens on exposure to the air. The wart-like projections on the lower side of the abdomen near its posterior end are pierced with many hundreds of minute holes, through each of which proceeds a microscopic thread of the glue-like fluid we have mentioned. The wart-like projections are called spinnerets. The hundreds of tiny threads from the spinnerets are grasped by the spider's claws and twisted into several strands, which, woven together, make the fibre of which webs are built. A spider's thread, then, is a rope of several strands, and each strand is composed of many hundred lines, yet it is so light that it floats in the air, so strong that it easily holds up many times the spider's weight, so elastic that it does not 
break easily, but stretches when struck heavily by large insects, and so pliable that it can be moved into any shape. No wonder, then, that the spider values so highly her magic thread, and economizes it to such an extent that she even eats the broken webs rather than have them wasted.

The spider's web is used in different ways by different members of the spider family. The trap-door spider builds her cylindrical home underground, lining it with the most delicate silk, and fitting it with a hinged cover which she closes in time of danger, holding it firmly shut with her claws.

The water-spider builds her dome-shaped home under water, arranging it like a diving-bell, and carrying to it bubbles of air from the surface (Fig. 86). Some spiders weave irregular, sprawling tangles of web to trap. their prey, while others build in accordance with a methodical pattern. One spider spins her web in such a way that it entangles in its meshes particles of warm air, thus forming a balloon with which to float in the air. The wheel-shaped web of the common garden-spider is a marvel of skill. To make it the spider first spins a thread where the wind can waft it to an anchorage on some distant twig, or other support. This line she hauls taut with her claws, and then, dropping and swinging, always holding a thread, she makes the somewhat irregular outside framework for her more accurate geometrical web. She then puts in the spokes with great care, and beginning at the middle, winds a spiral thread to the circumference, and another back to the centre. The second spiral thread is covered with little, sticky, transparent beads standing side by side, ready to catch the luckless fly by wing, or leg, and hold him fast. A touch of the finger to such a thread shows the adhesive quality of the beads, and a look at them under the microscope reveals their beauty.

Such a web is not a nest, or a house; it is a trap. 
Commonly the spider builds her home at one side of the trap, and, holding in one claw a thread which she

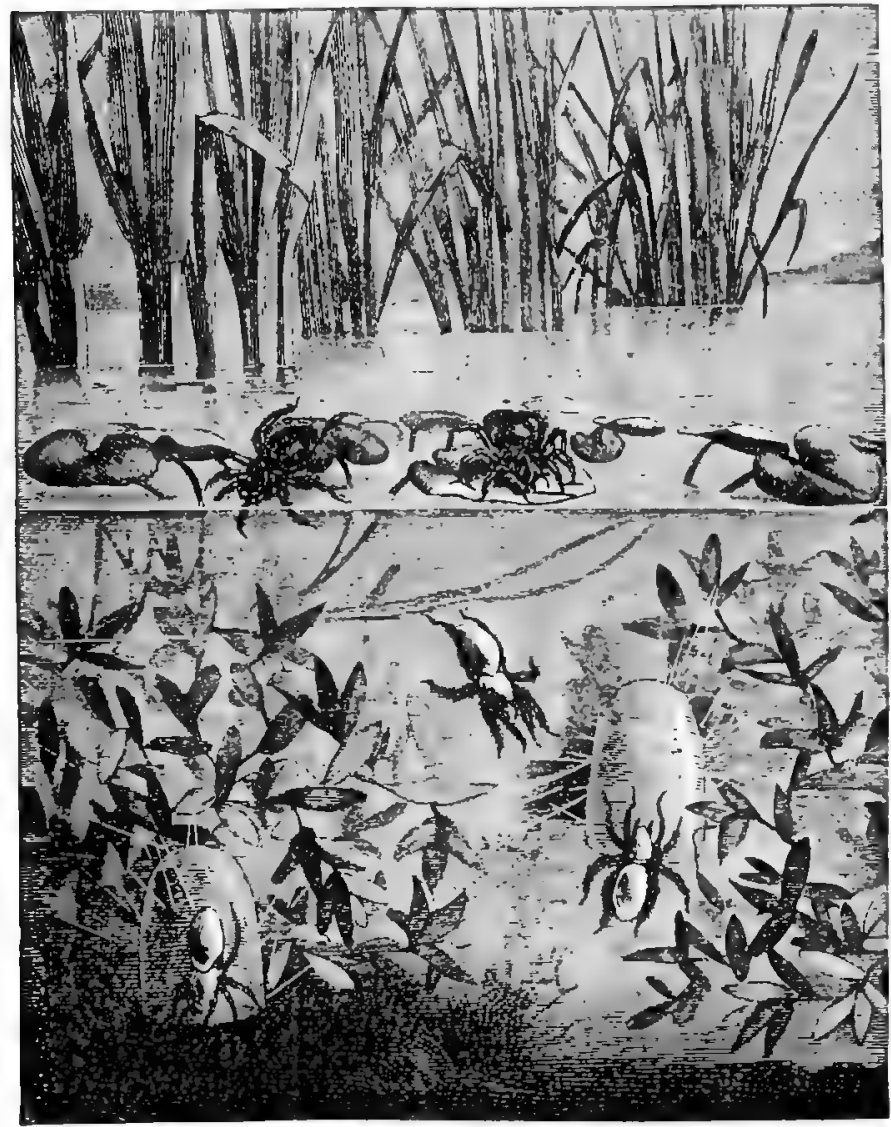

Fig. 86.-Water-spider and Nest.

has connected with the trap, she awaits the vibration which warns her that an insect is ready to be eaten. If the pull on the line indicates a fly, she simply goes 
directly to it, holds it in her mandibles, sucks the fluids from its body and throws away the shell. If, however, the pulling indicates a wasp or bee the movements are of a different kind. Then the spider shows both caution and alertness. If the insect is evidently too large to attack, the spider snaps a few threads of her web and sets the captive free with as little loss of the precious web as possible. If, however, there is a chance of victory; the spider spins more threads and winds them round and round her victim, until she has him so hopelessly entangled that she can safely kill and eat him at her leisure.

The entrance to the spider's mouth is guarded by a pair of mandibles with sharp fangs at their tips. These tips have holes near the ends, which lead by tubes to a poison-bag in the head. From these fangs the poison is squeezed into the body of the fly or other insect.

Nutrition. The spider's food is always liquid, and is pumped up into her stomach in somewhat the same way as the butterfly's honey. In the stomach it receives fluids which change it chemically, so that it can be used to nourish the body.

Respiration. Like the insects we have studied, the spider has spiracles for breathing, but so active and energetic an animal requires more oxygen than this arrangement seems able to give, and so it is provided with rudimentary lungs or air-sacs. These sacs are situated in the anterior part of the abdomen near its junction with the cephalothorax, and open by two minute holes just behind, the last pair of legs. The chemistry of breathing is the same in all animals.

Reproduction. The spider deposits her eggs in a cocoon of silk which she makes with great care, shaping it with her body as a bird shapes her nest. This cocoon, with its eggs, is fastened in a sheltered place. The young spiders are hatched quite complete, like their mothers, and begin at once to spin each a 
tiny thread. They moult often, and very soon, without any teaching, they know how to spin their tiny wheel-shaped webs. They cat other insects, as do their elders, and often dine on once another. fior them the struggle for existence is a fierce ance, and dontestic relations count for little, the mother catting not wily her own children, but often making a meal of her husband. In the spider family the mother is suprente and husbands and children fare but ill.

Discovery. An examination slows how larke is the nerve-mass concealed in the cephalothorax of the spider. Several ganglia have grown together and produced a sort of second brain, considerably lather than the nerve-mass which liss above the throit. Not only is this brain large, but its it is made by the concentration of many smaller nerve-nlatsis:s, of hitnglia, it represents a great concentration of powcer. These nerve-masses are connected with the ontwicle of the spider's body cverywhere by nerves, which calry to the central organs notice of all vilurations fiom willsout. 'The spider then is extremely sensitive to ally change in its surroundings. It sees, though not very clearly, by means of eight cyes plitced on the front part. of the cephalothorax; it hears, if at all, by the: viluration of the hairs on its body. It tastes and sumells, we have no doubt; but its kecenest sense is that of truch.

Movements. The spider is caprible: of few muvements and performs these cxccedingly well. What she loses by the alsenence of wings sloe gains by increise of power and skill in the use of luer legs. The milsing: of a web often recpuires the most delicatte menvenuent and the greatest precision; and the spicler shows this delicacy and precision to jerfection. Tlu: wonderful thing about the spider's automatic movennents is the accuracy with which they are controlled.

The Lithobius. For purpose of comparisen a little time may be devoted to the many-lespred forewn insed ts which disappear so hurriedly when onc overturns a 
board or stonc, in almost any field or garden. In some localities these animals are caller " earwigs ", in othcr places they arc known as centipedes. Another name for the most common species is lithobius. Specimens may be easily obtained by using tweezers or a piece of cloth. They may be kept in alcohol or formalin.

In note-books answer these questions:

What is the habitat of this animal ?

Does it prefer light or darkness?

Does it prefer moist or dry places?

Does it bite or suck its food?

In what respects does it resemble the spider? The grasshopper?

How does it differ from both spider and grasshopper?

Does the number of segments correspond with the number of legs?

The front feet have poison-claws. Do these feet have the same shape as the others?

Drawing. A sketch of lithobius.

Questions. I. How do the breathing-organs of a spider differ from those of the insects previously studied?

2. Do you think the spider's breathing has any relation to his activity?

3. Have you noted any protective devices among spiders?

Topics for Reports. The Cochineal Insect. Aphides. Shellac. The Silk-worm. The Manufacture of Silk Gronds. The Caddis-fly. May-flics. The Ant-lion. The Nrises of Crickets, Mosquitoes, and Bees. The Hal,its of Honey-bees. The Carpenterbee. Agricultural Ants. Mud-wasps. How Flies Walk on Ceilings. The Senses of a Fly (experiments). The Senses of a Spider (cxpcriments). Spiderwebs. Water-spiclers. Trap-door Spiders. Scorpions. Cheese-mites. Ccntipedes. Thousand-legs. Stings and Poisons. The Sense of Sight in Spiders. Where 
I Have Found Spiders. Are Spiders of Any Use? The Mosquito's Boat. My Experience in Rearing Butterflies. Lightning-bugs. Injurious Insects. Some Insect Friends. Aphides as Cows of Ants. Valuable Substances Furnished by Insects. The First Papermakers. Do Insects Talk? Insects I Dislike.

\section{VOCABULARY.}

A e'ri al (Gr. aer, the air), inhabiting the air.

A quat'ic (Lat. aqua, water), inhabiting the water.

Ceph al o tho'rax (Gr. kephale, head, and thorax), the union of head and thorax in one division of the body.

Drone, a male bee.

Fau'na (Lat. Fauna, the sister of Faunus, the god of agriculture), the characteristic animals of a district.

Hab'i tat (Lat. habito, to dwell), the natural abode of an animal.

Ma rine' (Lat. mare, the sea), inhabiting the salt water.

Range, the region in which an animal naturally lives.

Spin ner et', one of the projections from which the spider's web issues.

Su ture (Lat. suo, to sew), a seam or joint.

Ter res'tri al (Lat. terra, the earth). inhabiting or living on the land. 


\section{CHAPTER X.}

\section{HOMOLWTES AMNAG CRISTACEA.}

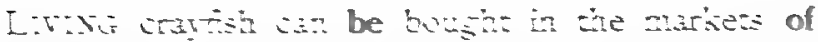
:

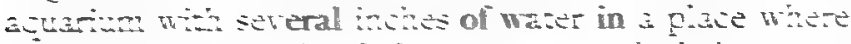

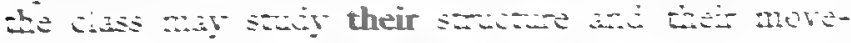

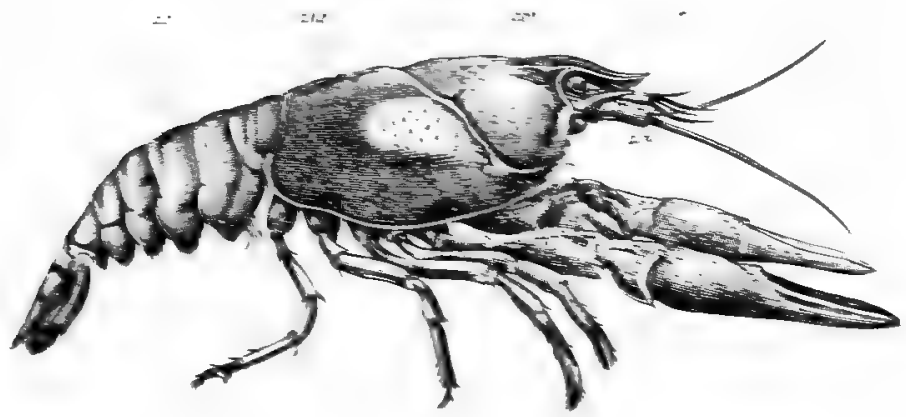

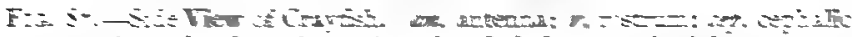

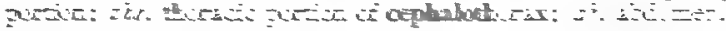

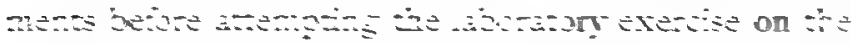

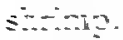

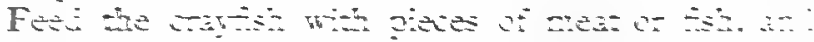

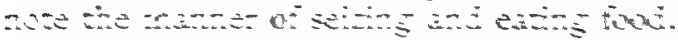

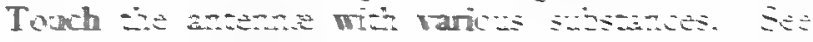

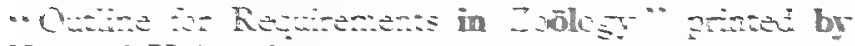

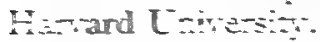

$Y:=2$ how the

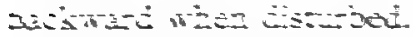


Place some colored liquid from a pipette just in front of the thorax at the opening of the gill-carity.

For individual work by the pupil, the use of the shrimp is suggested because of the small expense and because of the necessary comparisons with the crayfish. Compare also with a lobster. The questions may be used with crayfish, shrimp, or lobster.

Place the shrimp, crayfish, or lobster in a saucer with the head turned from you.

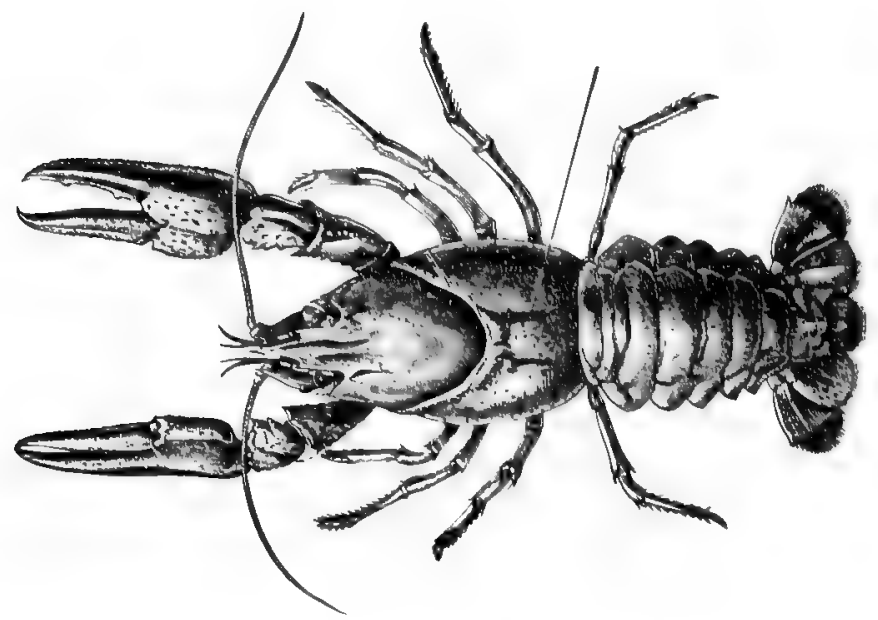

FIG. 88.-Dorsal View of Crayfish.

In what ways does the shrimp resemble the grasshopper?

How does it differ?

In what respects does it resemble a spider?

How does the exo-skeleton compare with that of the insects?

How many segments do you find in the abdomen?

Can you find any indications of a division between head and thorax? 
Are there any evidences of segmentation on the under side of the thorax?

The appendages attached to the abdomen are called savimmerets. At the end of the abdomen is the telson, which forms with the last pair of swimmerets the tail of the shrimp. The large claws used for grasping prey

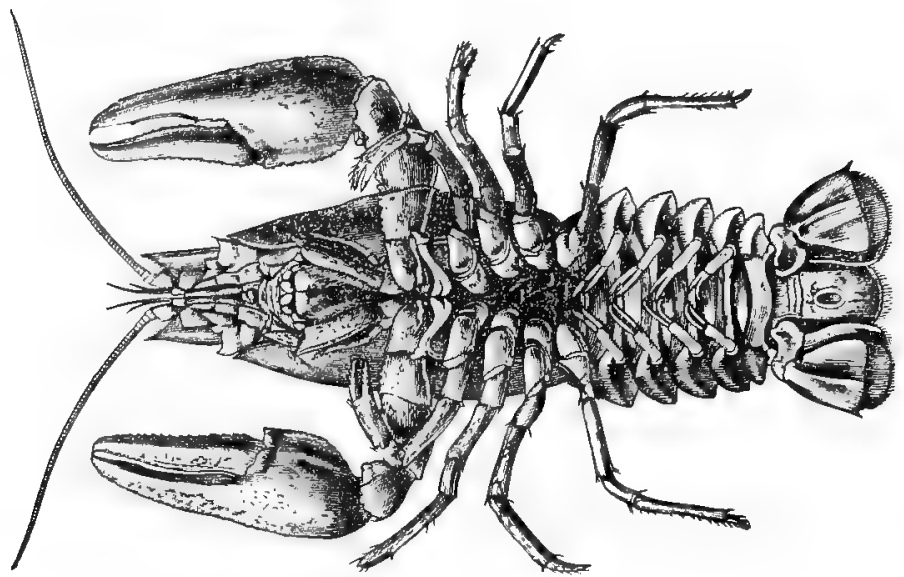

FIG. 89.-Ventral View of Crayfish.

are the first pair of legs. Count the legs and swimmerets. In what ways do the swimmerets differ from the legs?

Are all the legs alike? What differences do you observe?

In front of the legs are three pairs of foot-jaws used for passing food from the large claws to the mouth. These are called maxillipedes. In front of the maxillipedes are two pairs of maxillæ. In front of the maxillæ are the mandibles.

How many pairs of antennæ do you find? Are they branched?

How do the eyes differ from those of a grasshopper? 
Notice the form of one of the swimmerets on the second or third abdominal segments and compare all the swimmerets with this.

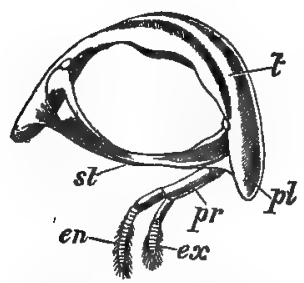

FIG. 90. - Fourth Abdominal Segment of Crayfish. $t$, tergum; st, sternum; $p l$, pleurum; $p r$, protopodite; $e n$, endopodite; $e x$, exopodite. One append. age has b een removed.

How do the other swimmerets differ from the ones first examined?

Infer a use for the sixth pair of swimmerets.

Sketch a swimmeret, naming parts.

Compare the ends of the legs having pincers with those which do not have those organs. How much extra growth would be needed to produce a pair of pincers on the last pair of legs?

Examine all the jointed appendages on one side of the body. How many do you find? Counting a pair of appendages to each segment or somite, how many segments has a crayfish or shrimp?

How do the mouth-parts of a crayfish or shrimp differ from those of a grasshopper?

Remove one side of the carapace and expose the gill-cavity. Do you find gills at the base of all the legs? Do you see the spoon-shaped gill-scoop? Of what appendage is it a part?

Look on the inside of the basal joints of the legs to find the outlets of the reproductive organs. Among crayfish the females have these openings on the middle pair of legs and the males on the last pair.

With the help of the drawings find the openings of the green glands (renal openings).

Find the ear.

Where is the anal opening ?

Internal Structure. With an alcoholic specimen one can make out the parts indicated in the figure below. The position of the heart, digestive tube, and 
nervous system should be especially noted. In looking for the heart remove the top of the carapace where you see the depression just behind the line between head and thorax.

Summary of Drawings. (a) Side view of shrimp $\times 4$ (omitting appendages).
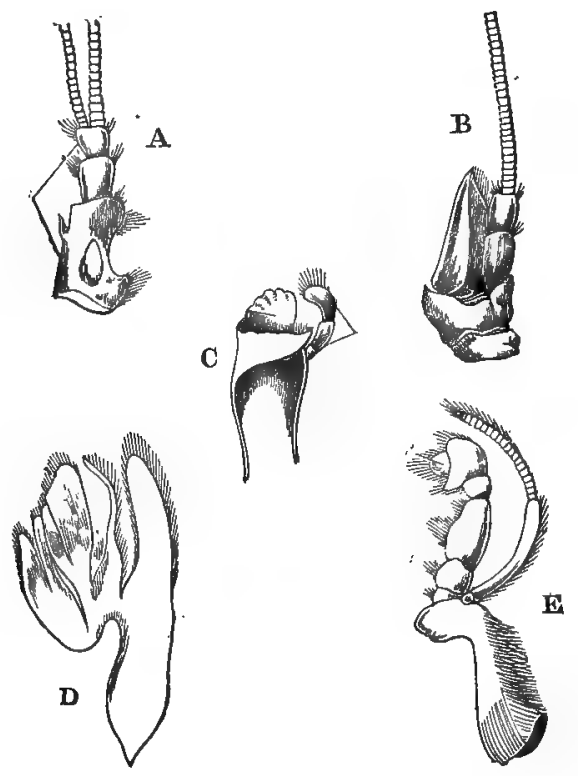

FIG. 9I.-Cray fish Appendages. $A$, antennule; $B$, antenna; $C$, mandible; $D$, second maxilla; $E$, second maxillipede.

(b) The carapace seen from above $\times 4$.

(c) Side view of thorax with carapace removed to show gills $\times 4$.

(d) An eye seen from above $\times 6$.

(c) Large antenna $\times 6$.

$(f)$ Small antenna $\times 6$.

$(g)$ First, second, and last leg $\times 4$. 
(h) A swimmeret from the third abdominal segment seen from behind $\times 6$.

(i) Sixth swimmeret.

Homologies. In the lobster, shrimp, and crayfish, the antennæ, claws, legs, and swimmerets are seen to

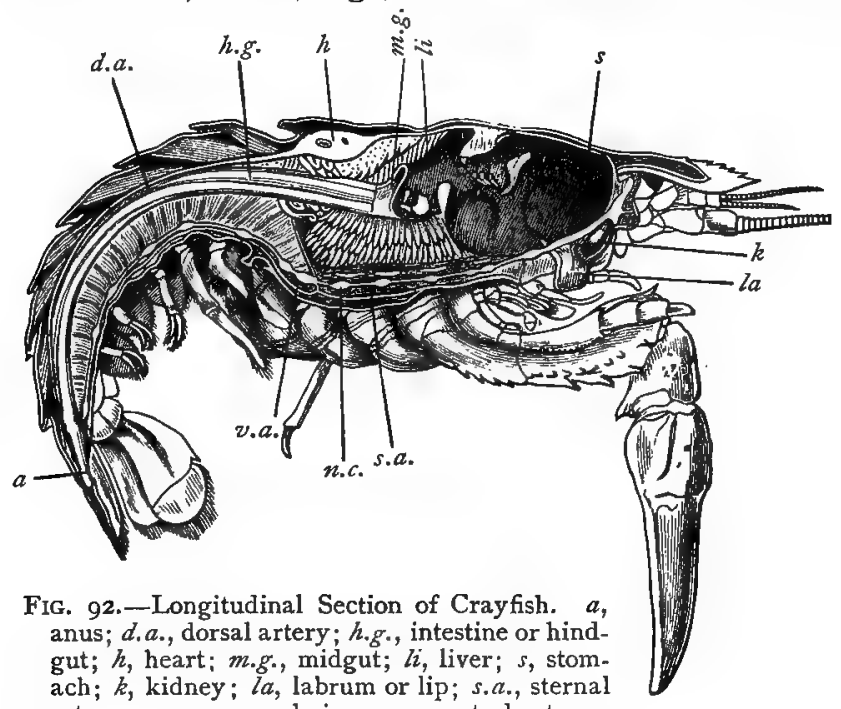
artery; n.c., nerve-chain; v.a., ventral artery.

be similarly situated and to bear a strong resemblance in structure. If we should study the growth of these three animals, we should find that these appendages arise in a similar way in the process of development. Parts of animals similar in position, structure, and origin are said to be homologous. The wings of the butterfly are homologous with those of the grasshopper. The three pairs of jointed legs in the caterpillar are homologous with the legs of the butterfly.

When parts correspond simply in use and not in origin or structure, they are said to be analogonts. Thus the wing of a bird and the wing of a butterfly are analogous but not homologous. 
Serial Homology. In comparing the jointed appendages of the different segments of the abdomen of a lobster or crayfish with one another, we note the fact that each is composed of a basal joint of two segments and a pair of jointed branches. One part of the basal joint is called the basipodite and the other the coxopodite; both together are called the protopodite. The inner branch is the endopodite, and the outer branch the exopodite. In the other jointed appendages we find striking similarity to the swimmerets. They are also similar in origin; starting as bud-like outgrowths from the rings or somites of the embryo. Indeed, each segment is homologous with every other. This kind of homology is called serial homology. It is very noticeable among the crustacea.

Laboratory Exercise. Examine a sand-hopper and an asellus.

How does each compare with the shrimp in regard to:

(a) The number of legs?

(b) The number and form of swimmerets?

(c) The number of antennæ?

(d) The number of segments?

(e) The divisions of the body?

$(f)$ The eyes ?

(g) The carapace?

(h) The position of the gills?

(i) The general form of the body?

Name parts of the sand-hopper which are homologous with those in the shrimp.

Name an organ in the sand-hopper which is analogous to one in the shrimp but not homologous with it. 
Compare the eyes in the three animals.

The Importance of Homologies. We have already pointed out the fact that parts may be homologous and

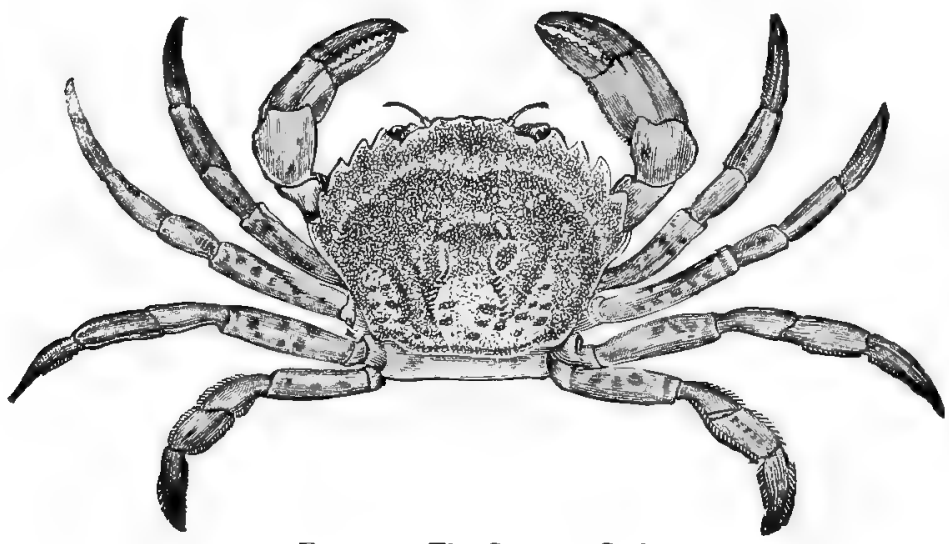

FIG. 94.-The Common Crab.

yet appear very unlike. Parts which arise in the same way in the processes of development may become so
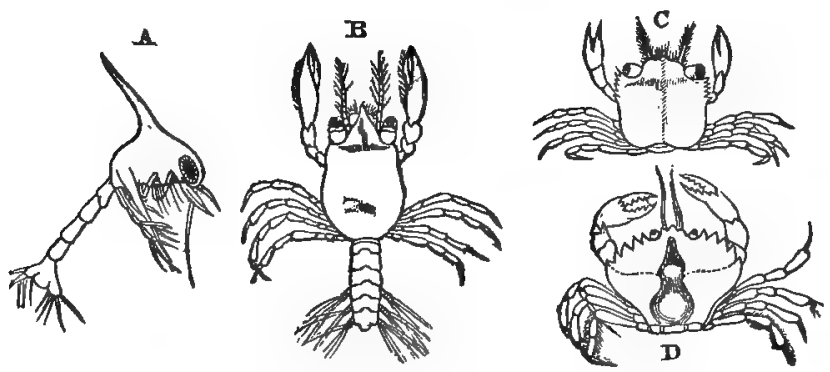

FIG. 95.-Early Stages of Shore-crab.

variously modified that their real homologies could not be known without a study of embryology. Hence it 
frequently happens that animals bearing only slight external resemblance to one another in adult life are classified together because in embryological life they show so many resemblances.

Among the ten thousand or more species of crustacea, there are many strange forms which depart from what might be called the typical crustacean structure. Comparing the common crab (Cancer irroratus) with the shrimp or crayfish, we notice the small size of the abdomen folded under the flattened carapace. In

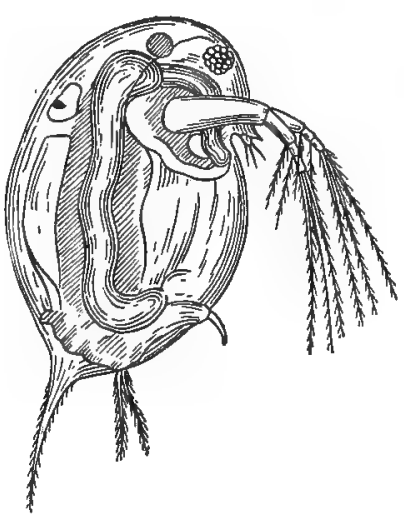

FiG. 96. - Water-flea (Daphnia pulex). the hermit crab the abdomen is soft and has lost part of the swimmerets, because of its habit of using the shell of a snail for protection, yet in the young the abdomen of this animal
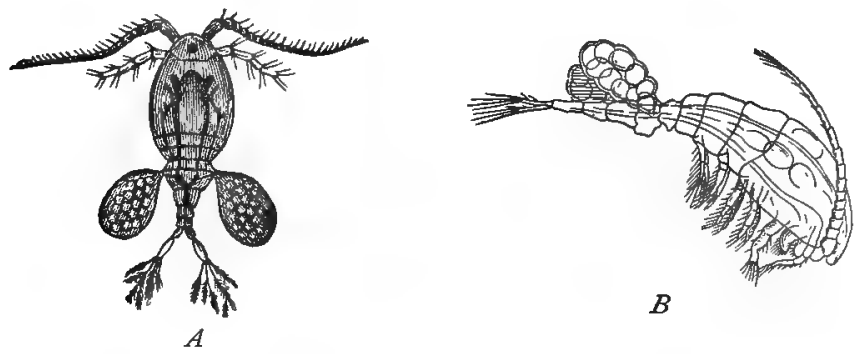

Fig. 97-Cyclops. $A$, dorsal view; $B$, side view.

is essentially like that of the young crayfish and bears homologous parts, 
Among the lower crustacea there are many which show greater variations from the typical form. The cyclops is a small lobster-like crustacean often found in drinking-water. Specimens can usually be obtained by tying a piece of muslin over the end of a faucet and allowing the water to run for a little while and then rinsing the muslin in a glass of water. The horseshoe crab is an ancient form sometimes classified with the spiders because it seems to have more homologies with them than with the common forms of crustacea.

Degeneration. The lower crustacea are called Entomostraca. Among these are found many forms which

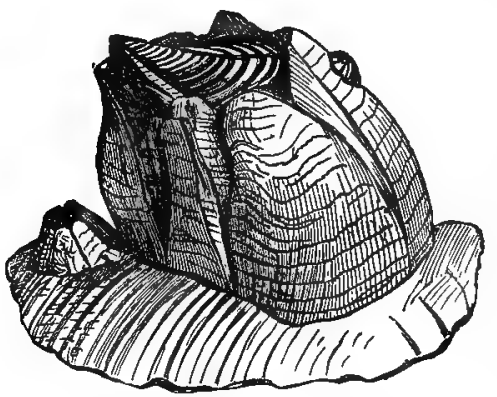

FIG. 98.-A Barnacle. would not be recognized as allies of the crayfish and crab, but for the study of their embryology. The c o $\mathrm{m} m$ o $\mathrm{n}$ barnacle (Balanus) found on all salt-water shores between high and low tide bears no resemblance to a crayfish, yet soon after hatching from the egg it is a freeswimming active crustacean, provided with organs of sense and looking much like a young shrimp. After a short time it seems to tire of its active life, and, looking about for a place of rest, it glues its head to a rock and lies feet uppermost kicking food into its mouth from the surrounding water. It builds around itself a conical shell which it opens and closes at pleasure. Thus sitting at ease and catching food as it comes, it has no use for organs of sense or locomotion and so loses these marks of higher animal life. It finally becomes a blind and stupid mass, capable of little else than the digestion of food brought to it by the 
waves, an excellent illustration of the loss of powers by disuse.

There are also many forms of fish-lice which live a parasitic life by attaching themselves to a portion of some fish and living on either the blood or food of their host. These bear very little resemblance to the crayfish. Some have even lost the gills and breathe only by the external surface of the body. These fish-lice hatch from the egg as free-swimming larva, bearing a striking similarity to other crustacea at this stage of growth. The common larval form is called the nauplius. (See first stage in Fig. 95.) It has a single eye and three pairs of appendages. The higher crustacea pass through this nauplius stage before hatching from the egg. From this stage, the higher forms of crustacea which lead an active life develop more appendages, and more acute sensibilities, with a corresponding increase of complexity in the nervous system, while the parasitic forms lose the eyes and locomotive appendages, and their whole structure degenerates into machinery for digestion and reproduction.

\section{AN EXERCISE FOR THE NOTE-BOOK.}

Rule a page in your note-book in the manner indicated on p. I I 2 and fill the blank spaces with such descriptive terms as you have learned in the previous lessons.

Classification of the Arthropoda. We have already noted the characteristics of the class "Insecta" by selecting the points of resemblance among them. We readily see that the spider, the lithobius, and the crayfish cannot be classed as Insecta without changing our present definition. We find it more convenient to include all the animals thus far studied in a larger class which naturalists have agreed to call Arthropoda. The Arthropoda are called a sub-kingdom or phylum because they constitute one of the large divisions of the 


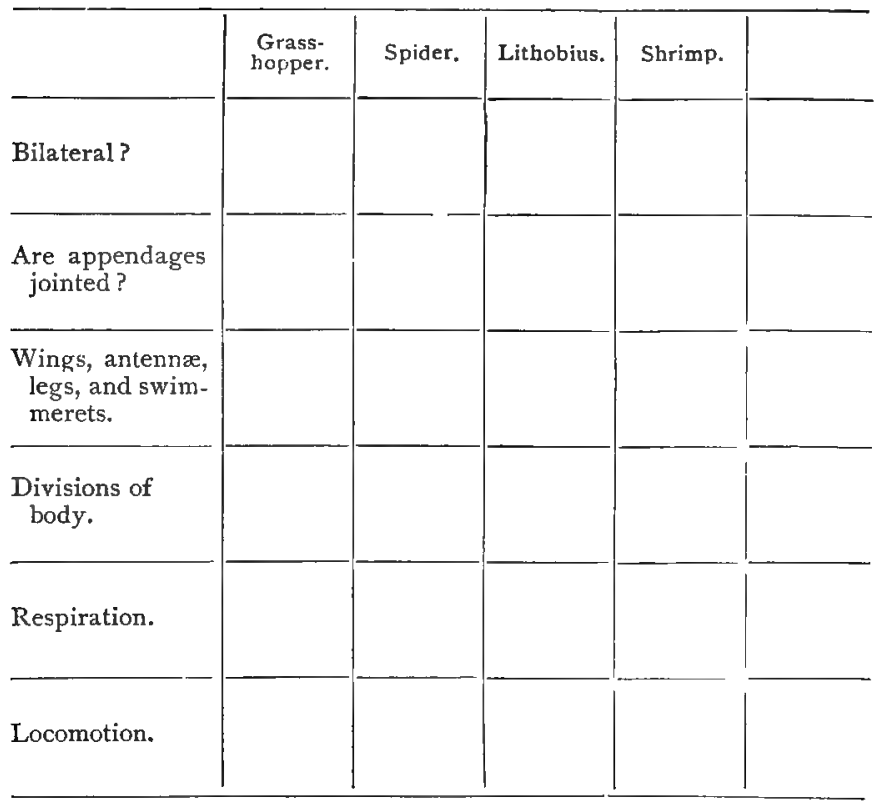

animal kingdom. Sub-kingdoms are divided into Classes, classes into Orders, orders into Families, families into Genera, genera into Species. Thus the milkweed-butterfly belongs to the sub-kingdom Arthropoda, the class Insecta, the order Lepidoptera, the family Nymphalidæ, the genus Danais, and the species Archippus. Such an arrangement must be to some extent artificial, because animals are not run in molds like bullets or stamped with dies like coins. Nevertheless, the great number of animal forms compels us to adopt some scheme of classification to prevent confusion.

Examining our notes concerning the Arthropoda, we find that all are bilateral, all have an exoskeleton, segmented bodies, and jointed appendages. These 
peculiarities we may call the most important characteristics of the Arthropoda. Animals not having these marks must be classified under other sub-kingdoms. In Chapter I we have classified all animals into eight sub-kingdoms. The sub-kingdom Arthropoda includes probably half of the animals of the earth, the Insecta alone having more than half a million species. Naturalists are not agreed yet as to the number of classes properly belonging to the Arthropoda, but usually animals like the shrimp and crayfish are called Crustacea, those like the lithobius Myriapoda, those like the spider Arachnida, and those like the grasshopper Insecta. The Insects have already been described.

The Arachnida have eight legs, simple eyes, and a cephalothorax and abdomen.

The Myriapoda have many segments with at least one pair of jointed legs for each segment.

The Crustacea breathe by gills throughout life. They pass through the nauplius stage in the course of development.

Further study shows other marks for identifying these classes. Many exceptional forms are found and great patience and care are necessary in order to classify accurately. Nevertheless, it is profitable practice to attempt to classify animals as we see them, even if we do it somewhat roughly at first.

Laboratory Exercise for Review. A variety of forms kept separately in small numbered boxes and bottles may be used. Write in the note-book:

(I) The number of the specimen.

(2) Its mode of locomotion.

(3) Its habitat, inferred from its structure and its resemblance to forms already known, with the reason for your answer.

(4) Its food and its mode of procuring it, inferred from an examination of its mouth-parts, from other points of structure, and from resemblances to forms already known, with the reason for your answer. 
(5) The class to which it belongs, with reasons for the answer.

(6) In the case of Insecta, name the order to which the insect belongs, with reasons for the answer.

Questions. (I) Why are the animals just studied called crustacea?

(2) How does their manner of breathing compare with that of Insecta?

(3) Do lobsters breathe air? Explain.

(4) What is meant by homology? By analogy?

(5) What is serial homology?

(6) Where may one find cyclops ?

(7) Why is cyclops so named?

(8) How do the crabs differ from the shrimp?

(9) In what way do barnacles resemble the shrimp ?

(IO) How does the hermit-crab differ from other crabs?

(I I) In what cases among crustacea does the mode of life seem to affect the shape of the body?

(12) What occurs when the limb of a crustacean is broken off? What reason have you for your answer?

(13) What is phosphorescence? How do you explain it?

(14) Do the crustacea moult ? How do you know ?

(I5) Do you know any animals which do not have both sides alike?

(16) Give examples of differentiation.

Topics for Reports. The Hermit-crab. Robbercrabs. Lobsters. Cyclops. Phosphorescence. Giant Crustacea. Degeneration. Uses of Crustacea. 


\section{VOCABULARY.}

An al'o gous (Gr. ana, according to, and logos.) Analogous organs are those having the same use but not necessarily the same structure or origin.

Bas ip'o dite (Lat. basis, base, and Gr. pous, foot), part of a crustacean appendage.

Car'a pace (Lat. capara, a hood), the hard covering of the cephalothorax in crustacea.

Ceph al i za'tion (Gr. kephale, head), a tendency to aggregate nerves and organs of sense near the head.

Cox op'o dite (Lat. coxa, hip, and Gr. pous), the joint of a crustacean appendage nearest the body.

Crus ta'ce a, a class of arthropoda commonly having a hard shell.

Dec'a pod (Gr. deka, ten, and pous), an order of crustacea having ten legs.

Dif fer en ti a'tion (Lat. dis, apart, and fero, to carry), the setting apart of tissues and organs to perform special kinds of work.

Em bry ol'o gy (Gr. embryon, an embryo, and logos), the study of embryonic life.

En dop'o dite (Gr. en, in, and pous), the outer branch of id swimmeret.

Ex u'vi um (Lat. exua, to strip off), the cast-off skin of an insect or crustacean.

Fang, a hollow tooth emitting poison.

Fer til i za'tion (Lat. fero, to bear), the union of male and female cells to produce living seeds or eggs.
Gill, an organ for breathing the oxygen dissolved in water.

Ho mol'o gous (Gr. homos, same, and logos), having the same relative position and structure.

I'so pod (Gr. isos, equal, and pous), an order of crustacea having the legs of equal length.

Maxil'li ped (maxilla, and pous), a. foot-jaw.

Os mo'sis (Gr. osmose, pushing), an interchange of gases or liquids through a slightly porous substance.

Pro top'o dite (Gr. protos, first, and pous), a part of a swimmeret consisting of the basipodite and coxopodite.

Re'nal (Lat. renalis, kidney), pertaining to the kidneys.

Ros'trum (Lat. rostrum, a beak), a weapon of defence on the front of the carapace of a crustacean.

Sed'en ta ry (Lat. sedeo, to sit), inactive.

Ses'sile (Lat. sedeo, to sit), jointed to the body without stems or stalks.

So'mite (Gr. soma, a body), a segment of the body of one of the arthropoda.

Swim mer et', a jointed appendage on the abdomen of a crustacean.

Tac'tile (Lat. tango, to touch), having the sense of touch.

Tel'son (Gr. telson, a boundary), the posterior somite of a crustacean.

Tet ra dec'a pod (Gr. tetra, four, deka and pous), an order of crustacea having fourteen legs. 


\section{CHAPTER XI.}

\section{THE ACTIVITIES OF ONE-CELLED ANIMALS AND SPONGES.}

THus far we have been dealing with animals having more or less complicated machinery for carrying on the activities of life. We know that an egg is a single cell and that as it grows it changes by increasing the number of cells and by setting apart groups of these cells to perform different duties. In a single cell life is reduced to its lowest terms. In an egg we may see the process of unfolding and get greater insight into the workings of living machinery. So in studying living animals which never develop beyond the singlecell stage of existence we may gain a knowledge of animal activities not otherwise obtainable.

These animals are so small that a complete study of them makes necessary the use of the compound microscope, but as it is not proposed to burden this course with the details of microscopic manipulation, we must content ourselves with verbal descriptions for the present.

The one-celled animals are put in a sub-kingdom by themselves, called Protozoa. They are very small and for the most part inhabit the water. There are many of them, but their ways may be very well understood by studying descriptions of a few forms.

The Amœba. This minute animal has been much studied and its modes of life are well known. It may be found in stagnant water in small shallow pools. It is less than a hundredth of an inch in diameter and 
under the microscope looks like a drop of moving jelly of irregular outline. The greater part of the Amœba is granular in structure, being surrounded by an outer film of clearer jelly. In the midst of the cell is a nucleus, a little more opaque than the rest of the cell but made of the same substance. The jelly-like substance of which the whole Amoba is made is called

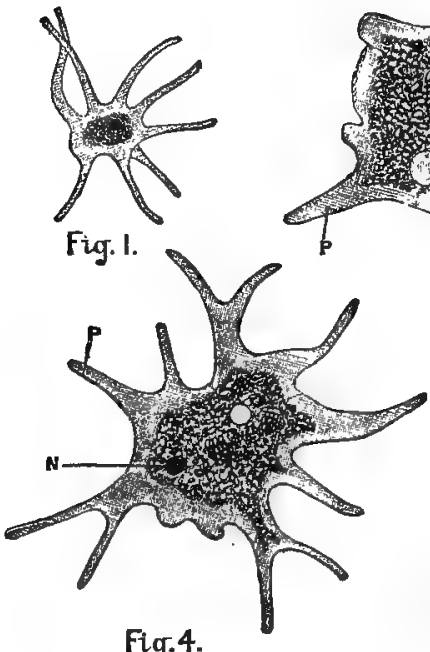

Fig.4.

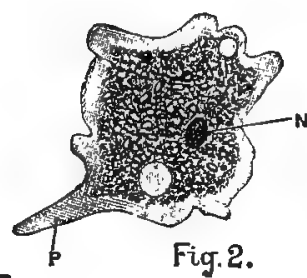

Fig.2.
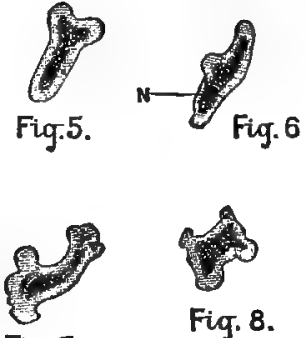

Fig.7.

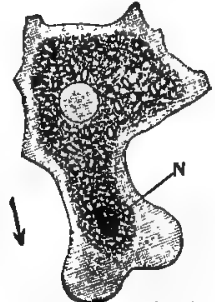

Fig.3.

FIG. 99.-Forms of Amœbæ (highly nagnified). 2 and 3 were drawn from the same specimen; $5,6,7$, and 8 were drawn from another specimen; $N$, nucleus; $P$, pseudopodia.

protoplasm. The same substance is found in the cells in our own bodies, as well as in the living cells of other animals and plants. Every plant and every animal begins its life as a single cell of protoplasm. Within the Amœba's cell may be also seen a round clear spot which from time to time contracts and temporarily disappears. This is called the contractile vacuole. 
Taking Food. Not only is the Amcba destitute of jaws and sucking-tubes, but it even lacks a mouth. Its food consists largely of minute one-celled organisms which it swallows at any part of its body by simply flowing over and around them.

Nutrition. The particles of food which have been swallowed are gradually dissolved and chemically changed so as to become a part of the protoplasm of the Amœba's body. The shell of the plant is thrust out through the Amœba's covering at any point when all the nutritious matter has been taken from it. Dissolving and chemically changing the food is digestion. Making it a part of the Amœba's protoplasm is assimilation. There is no stomach or intestine, but the food while digesting moves about with the granular protoplasm in a somewhat regular way.

Respiration. There are no organs for breathing, but oxygen from the surrounding water enters the living protoplasm and carbon dioxide and other impurities are given off.

Reproduction. When the Amœba has eaten and digested food until it has grown to be too large, the
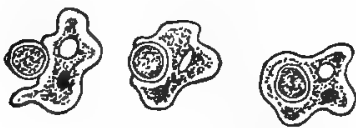

Frg. roo.-Amœba Feeding. nucleus shows signs of dividing, the Amœba assumes a dumbbell shape and finally splits into two Amobas, each equally capable of leading an independent existence. Parent and offspring are alike, if either can be called parent. This mode of reproduction by division is called fission.

Discovery. If touched the Amœba contracts. It is then sensitive to touch, but there can be no special parts of the body fitted to receive impressions from without. It is everywhere equally sensitive.

Movements. Not only does the Amœba withdraw when touched, but it seems capable of self-directed movement as well. The method of procedure consists 
in projecting outward a portion of the body in the direction in which the animal wishes to move. The little swelling thus made is called a pseudopodium or false foot. Such false feet may appear at any time on any part of the body. When this pseudopodium has extended itself sufficiently the rest of the body seems to glide into it by a sort of flowing motion. The varying position and size of the pseudopodia give it its irregular outline when seen under the microscope. The Amœba's power of "contractility" is sometimes spoken of as a separate activity corresponding to the contractility noticed in the muscles in higher animals.

Thus this simple bit of protoplasm performs the same functions which are common to higher animals, all the activities in this case being carried on by a single cell. As we examine other animals we find it easy to arrange a series in which each animal is only a little more specialized than the one next below it, but such a series does not include all animals. It is interesting to note that such a series bears a strong resemblance to the various stages through which an egg (a single cell) of one of the more specialized members of the series passes in its growth.

Rhizopoda with Shells. Some of the Amœba-like animals cover their bodies with bits of mineral matter to form shells with openings through which the pseudopodia extend to gather food and assist in locomotion. In many cases these shells are secreted by the animal, that is, they are formed from the protoplasm

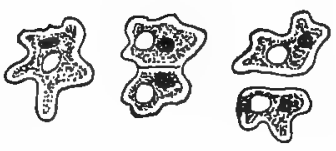

FIg. Ior._Amœba Dividing. of the body as our fingernails are formed from our blood. Sometimes the pseudopodia resemble the roots of plants and hence these Protozoa which move by pseudopodia are called Rhizopoda.

Some of the Rhizopoda secrete shells of calcium car- 
bonate or limestone. When these shells are perforated with many holes the animals are called Foraminifera.

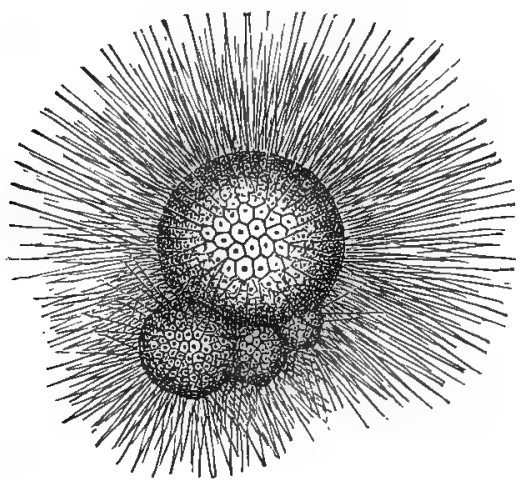

FIG. I02.- One of the Foraminifera.

Some of these foraminifera have been found of large size and in such great numbers that their fossil remains make great deposits of limestone.
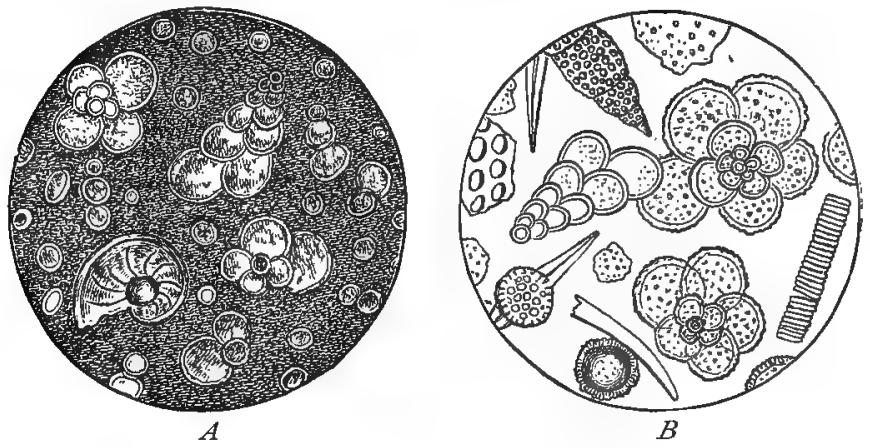

FIG. I03.-The Origin of Chalk. $A$, chalk (magnified); $B$, ooze (magnified).

Chalk. At present there live near the surface of the ocean great numbers of these shelled Rhizopods. 
When they die their shells fall to the bottom and, mingling there with other similar shells, form a soft white mud which may harden to form chalk. The chalk cliffs of England were doubtless produced in this way.

Tripolite. Some of the Rhizopoda have shells made of the finest possible bits of glass or silica. Deposits of these shells with similar shells of one-celled plants form tripolite, a substance used as a polishing powder.

Infusoria. If hay be placed in warm water and allowed to stand in a warm place for a few days the

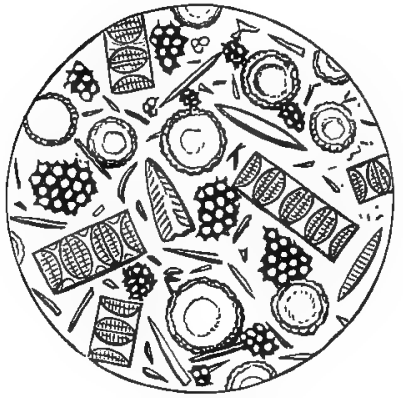

FIG. 104.-Infusorial Earth (magnified).
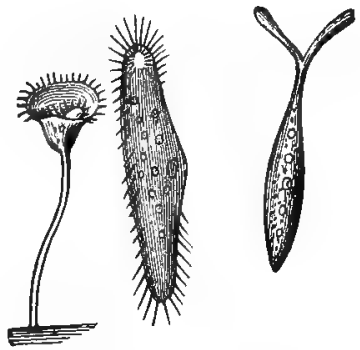

FIG. I05. - Infusorians (magnified).

water will be found to be filled with many minute, onecelled, rapidly moving animals. A look at these through the microscope shows that their movements are due to the motion of hair-like projections on the body. These hair-like bodies are called cilia. Onecelled animals which move by cilia are called Infusoria because some of their kind appear when infusions of hay or other vegetable matter are allowed to stand. Some of the Infusoria are fixed by a stalk, or stem, like the bell-animalcule, or vorticella, shown in the figure, and some are rapidly moving free animals like those found in infusions of hay. 
One of the Infusoria found in infusions of vegetable matter is the Paramecium, or slipper-animalcule (Fig.

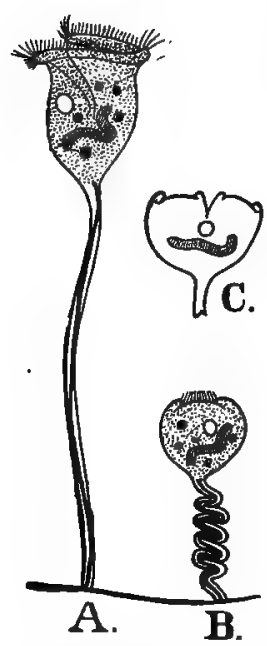

FIG, I06.-Vorticella (magnified). $A$, extended; $B$, contracted; $C$, in fission. 107). This may be found and studied very easily. Where a compound microscope is available the following exercise may be used.

Laboratory Exercise. Examine in a watch-glass by using a low power of the microscope a few drops of stagnant water known to contain Infusoria.

I. Does the Paramecium have a definite shape? Is it bilateral ? Is the Amœba bilateral?

2. Place a few drops of water containing the slipper-animalcule on a slide with a few fibres of cotton and examine with a higher power of the microscope. Is the body divided into parts or cells?

3. Do you see the movement of cilia? On what part of the body are they situated?

4. Do you find a groove surrounded by cilia?

5. Do you find a mouth ?

6. Do you find a nucleus?

7. Are there any contractile vacuoles ?

8. Feed the animal with bits of indigo. Where do the blue particles go?

Summary of Drawings. (a) A sketch of several animals as they appear when viewed with a low power of the microscope.

(b) Sketch of a single animal showing as many parts as you have seen.

In the Paramecium the activities of life are carried on much as they are in the Amoba. There is, however, a greater specialization of parts, especially the 
mouth for taking food and the two kinds of cilia, one for locomotion and one for producing currents of water to drive food into the mouth. Even a single cell then may have its parts specialized for performing different kinds of work.

Characteristics of the Protozoa. The Protozoa are minute a $\mathrm{n}$ i $\mathrm{m}$ a $1 \mathrm{~s}$ having but a single cell of protoplasm, moving by pseudopodia, or cilia, and reproducing withouteggs.

Sponges. It is not recommended that sponges be studied in the laboratory in an elementary course, but for purposes of comparison it is necessary to become familiar

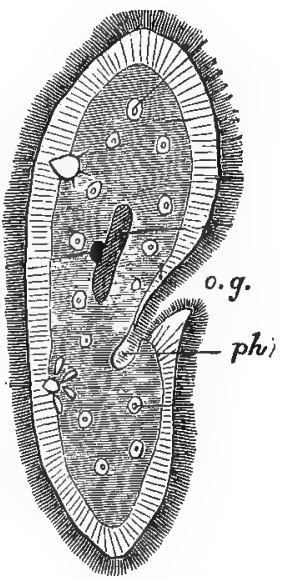

FIG. I07. - A Paramecium (highly inagnified). o.g., oral groove; ph, pharynx. with the most important facts concerning their structure.

Sponges are composed of many cells but slightly specialized. A single sponge really seems almost as much like a colony of Protozoa as like a distinct animal. The outer layer of cells which is simply a sort of skin is called the ectoderm; the inner layer or lining of the cavities of the body is called the endoderm. Between the ectoderm and the endoderm lies the mesogloca, in which the skeleton is produced. The flesh of the sponge taken altogether is called sarcode. The common bath-sponge as we use it is only the skeleton. We may imagine that the hard parts we see have once been imbedded in fleshy matter (mesoglœea); that the fleshy matter was covered with a skin (ectoderm); and that the cavities so apparent in the skeleton were lined with another skin (endoderm). 
The kind of sponge commonly called the hard-head gives a general idea of sponge-structure. The smaller holes on the cutside correspond to openings in the ectoderm through which currents of water flow to the interior cavities. The large holes at the top are out-

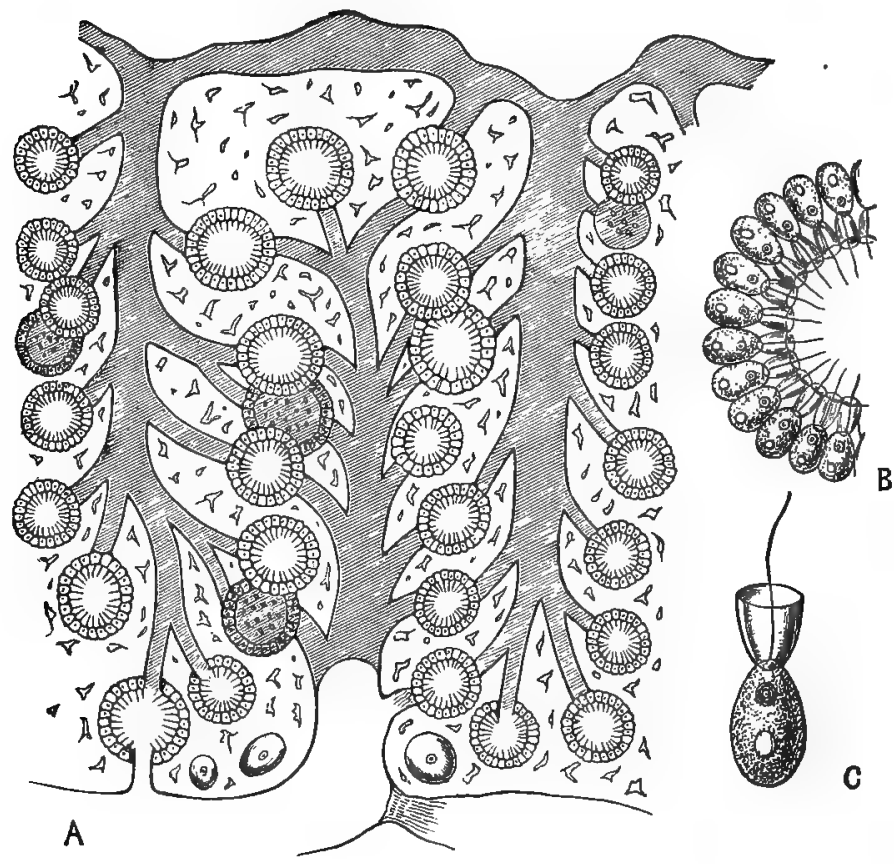

FIG. I08. - Structure of a Sponge (magnified). A, section of sponge; $B$, part of a digestive sac; $C$, one cell from a digestive sac.

lets for these currents. Along the passageways from these outer holes (inhalent pores) to the larger holes (oscula) there are enlargements which act like stomachs, that is, they take up the food as it passes along in the currents of water. The endoderm cells which line 
these cavities are provided with flagella which by their constant movement keep the water moving along from the inhalent to the exhalent openings. As the water passes along it brings within reach of $\mathrm{t} h \mathrm{e}$ flagella minute animals and plants which are seized and pushed back into the cells where they are dissolved and assimilated in much the same way as the food of the Amciba is assimilated in its cell. The breathing, too, is carried on by the indi-
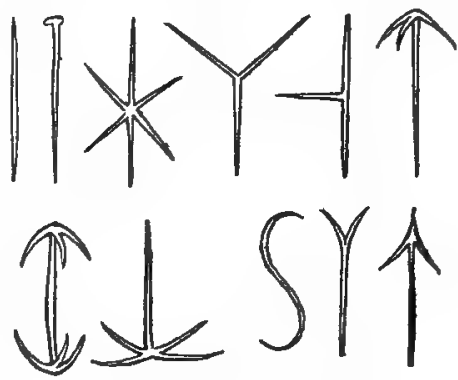

FIG. 109.-Sponge Spicules. vidual cells as in the Amcba. Nutriment from the endoderm cells is passed along from cell to cell to nourish the rest of the body. From this nutriment the material for building the skeleton is secreted. This skeleton is often in the shape of spicules of hard material. Spicules may be calcareous, silicious, or horny, producing these three kinds of sponges. Only the horny or keratose sponges are of any commerical use.

So nearly independent are the individual cells composing the sponge-structure that if a few of them be separated from the original body, they go on living and divide and subdivide, making new cells and building the structure of a new sponge. If a living sponge be cut into hundreds of pieces, each piece grows into an independent animal.

Such an aggregate of cells may be considered as only a transition step between a Protozoon and a many-celled animal of more highly specialized structure. Hence some naturalists have classed sponges as Protozoa, some make a separate sub-kingdom Porifera, while others class them with the sub-kingdom Colen- 
terata. For our purpose it seems best to regard the Porifera as a separate sub-kingdom.

Questions. I. What force propels the water through the canals in a sponge?

2. Write the functions of the sponge in columns as we have previously written the functions of other animals.

3. In what respects does the sponge resemble the Paramecium?

4. How does a sponge differ from an Amoba?

5. Where are sponges found?

6 . Why are sponges called animals rather than plants?

Topics for Reports. Chalk. Tripolite. The Discovery of the Microscope. How to use a Microscope. Sponge-fisheries.

\section{VOCABULARY.}

An i mal'cule (Lat. dim. of animal, from anima, breath), a very small animal.

As sim i la'tion (Lat. $a d$, to, and similis, like), the process of making digested food into living tissue.

Cal ca're ous (Lat. calx, lime), made of carbonate of calcium.

Cell (Lat. cella, a small room), a bit of living protoplasm containing a nucleus.

Cil'i a (Lat. pl. of cilium, \& hair), hair-like bodiès capable of rapid movement.

Ec'to derm (Gr. ektos, outside, and derma, skin), the outer layer of cells in a sponge.

Ec'to sarc (Gr. ektos, and sarx, flesh), the outer film surrounding one of the Protozoa.

En'do derm (Gr. endon, within, and derma), the inner layer of cells in a sponge, the layer which forms the lining of the digestive channels.
Fis'sion (Lat. fissus, a cleft), the process of reproducing by celldivision.

Fo ram i nif'e ra (Lat. foramen, a hole, and fero, to carry), Protozoa having shells punctured with many small holes.

In fu so'ri a (Lat. pl. of infusorium, an infusion), Protozoa moving by means of cilia.

Ker'a tose (Gr. keras, a horn), horn-like.

Mes'o derm (Gr. mesos, middle, and derma), the part between ectoderm and endoderm.

Nu'cle us (Lat. dim. of nux, nut), a denser bit of protoplasm in a cell.

Os'cu lum (Lat. dim. of os, mouth), a minute pore or mouth.

Pseu do po'dium (Gr. pseudos, false, and pous, foot), a projecting portion of an Amoba's cell, a false foot.

Pro'to plasm (Gr. protos, first, and plasma, form), the substance of 
which living cells are mainly composed.

Rhi zop'o da (Gr. rhiza, root, and pous), Protozoa having pseudo. podia for locomotion.

Sar code (Gr. sarx, flesh) the fleshy part of a sponge.
Si li'cious (Lat. silex, flint), made of a substance like glass.

Spic'ule (Lat. dim. of spicum, a spike), a bit of hard material formed in the tissues of sponges and other lower animals. 


\section{CHAPTER XII.}

THE HYDRA AND SOME CELENTERATES WHICH LIVE IN COLONIES.

Fresh-water Hydra. In warm weather hydra may be found near the surface of fresh water on leaves or sticks or attached to the stems of aquatic plants. If such leaves or plants be collected and placed in a plate, or jar of water in the sunlight, hydra may be seen in a short time. As soon as they have been found, transfer them with the plants on which they feed to an aquarium, where they may be easily kept all winter. They feed on cyclops, daphnia, and other small crustaceans. These are commonly found in the same places as the hydra and probably will appear in the water with the leaves collected. If they do not appear keep on collecting dead leaves from different localities until they are found. Both hydra and its food may be found almost anywhere if patience and care be used in collecting. When wanted for use it is easy to transfer hydras to a watch-glass by removing them from the side of the aquarium with a knife and dipping them out with a glass tube.

Note the appearance of hydras as you see them in the aquarium.

What is their size? their shape? Do all have the same shape?

Look for branches and buds. How many do you find on any hydra?

What is the color of hydra?

What movements can the hydra make? 
In what part of the aquarium with reference to light are they most abundant?

Place a hydra in a watch-glass in water and observe it more closely with a magnifying glass. What do you see?

Watch one take a particle of food.

Notice the foot, the body, the tentacles, the hypostome, and the mouth.

What happens when you touch a tentacle?

In what respects does the hydra resemble the sponge?

How do the two animals differ?

Cut a hydra in several pieces and place these in a dish in clear water. Watch the pieces for several days.

Place a single budding hydra in a battery-jar with water and food. At frequent intervals count the number of hydras present.

Summary of Drawings. (a) A single hydra with tentacles showing $\times$ IO.

(b) A hydra with tentacles contracted $X$ Io.

(c) A single hydra showing buds and branches $x$ Io.

(d) Several hydras in different positions taken in locomotion $\times$ Io.

The Activities of the Hydra. Taking Food. The hydra uses the tentacles surrounding the upper end of its cylindrical body for the purpose of seizing its prey and conveying it to the mouth. These tentacles are covered with minute nettling-cells which paralyze the small crustacean as soon as he is seized. These cells have within them a very minute coiled thread which is uncoiled when the cell is touched. This thread pierces the victim which has been unwittingly the cause of the uncoiling and poisons the part it pierces. These nettling-cells are sometimes called thread-cells or lasso-cells. They are characteristic specializations of the sub-kingdom Coelenterata.

Digestion. The food after being pushed into the 
mouth by the tentacles passes into the body-cavity, which is also a stomach.

The hydra is really a bag, being hollow, even out in the tentacles. The food moves about inside of this

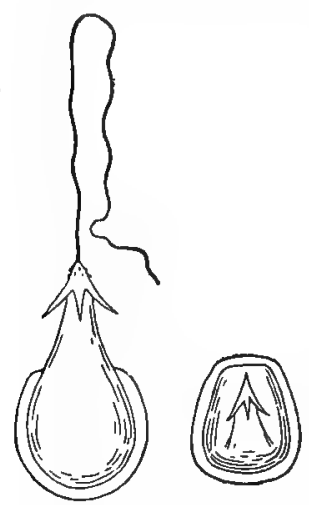

FIG. IIo.-Thread-cells (highly magnified). bag and is dissolved there. The hard and useless parts of the food are pushed out through the mouth, which is the only opening into the bag. The nutriment is assimilated by the cells lining the bag or stomach-cavity. This lining is called the endoderm and its cells are very little differentiated from the ectoderm, or outside cells.

Respiration. The cells of the hydra breathe independently, as do those of the sponge.

Reproduction. If the hydra is divided into several pieces each piece reproduces the missing parts and becomes an active individual. A common method of reproduction is by the process of budding. The buds appear first as swellings along the sides of the parent hydra; they gradually develop a row of tentacles; a mouth breaks through into the common cavity of both parent and offspring; the base of the branch into which the bud has now grown constricts and finally breaks away entirely from the parent; and the hydra, free and independent, seeks its own place of feeding.

But the hydra also reproduces by means of eggs. These appear as swellings on the side of the parent in much the same way as the buds just mentioned. Above the egg just below the fentacles another swelling appears. This contains the fertilizing or male cells (sperms). The swelling containing the sperm-cells is called the testis. The ova as they mature float away into the water, as do also the sperms. A sperm swims 
actively about and finally coalesces with an ovum from another hydra. This process is called cross-fertilization. Animals which produce in the same individual both ova and sperms are said to be hermaphrodite. We can see that this cross-fertilization does not differ materially from that already described as occurring in the white clover. The eggs after fertilization are called oösperms. These oösperms develop into hydras like the parents. In the autumn, eggs are produced with

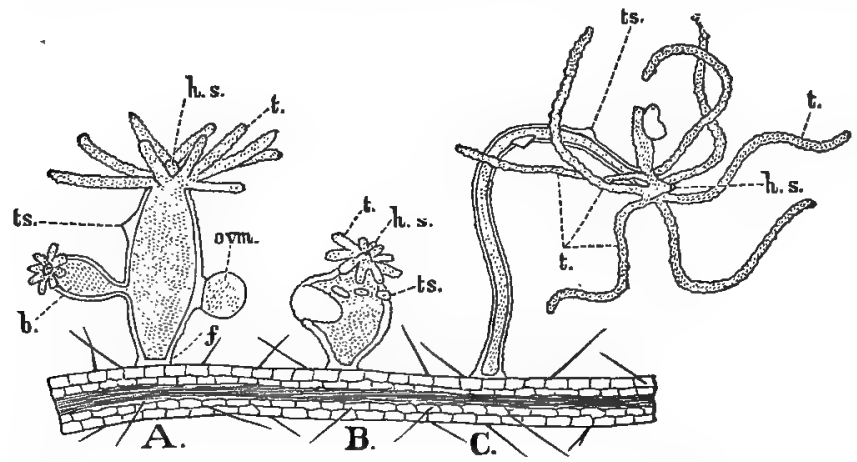

FIG. IIr.-Forms of Hydra (magnified). $A$, half retracted; $B$, fully retracted; $C$, extended; $f$, foot; ovm., ovum; $b$, bud; $t s$., sperm-cells; h.s., hypostome; $t$, tentacles.

thick, hard shells to withstand the cold and thus preserve the species until spring.

Discovery. The hydra has no nervous system, though a few nerve-cells are developed. It is sensitive to light and extremely so to touch.

Movement. The hydra moves without muscles. It can move by pushing its sucking-disk or foot along the leaf to which it is attached or it can march by somersaults to its destination. The tentacles seem to move at will.

The Hydractinia. Division of Labor. A saltwater animal which resembles the hydra is Hydractinia. 
It is often found attached to snail-shells inhabited by hermit-crabs. The individuals live in a colony and vary according to the work each has to do. They all grow together at the base, and so are connected by living tissue through which digested food may be passed from one to another.

Here one individual $(a)$ does the eating for the colony with the help of others like himself; another $(b)$ attends entirely to the work of reproduction; while still another (c) protects the colony from enemies. These hydralike individuals, which are not strictly individuals because they do not lead an independent existence, are called zooids. Such an assembly of zooids is called

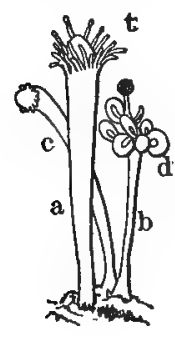

A

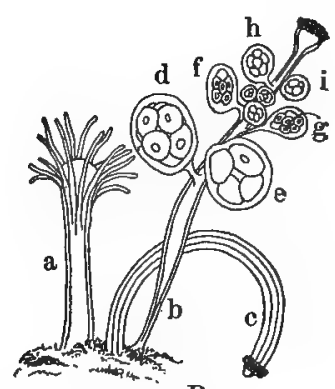

$\mathrm{B}$

FIG. I12.-Hydractinia (magnified). After Agassiz. $A$, male colony; $B$, female colony; $a$, feeding zooid; $t$, tentacles; $b$, reproductive zooid; $\dot{c}$, protective zooid; $d, e, f, g, h, i$, stages of jelly-fish.

a colony. Again we notice the setting apart or differentiating of zooids to perform each its own work.

At the base of the zooids of Hydractinia a hard skeleton is built, which resembles coral in its nature.

Commensalism. As stated above, the Hydractinia is commonly found on shells inhabited by hermit-crabs. The Hydractinia colony is thus carried about and brought constantly into contact with a new food-supply. 
The hermit-crab, on the other hand, is probably protected from enemies by the moss-like growth on its shell. The two animals seem to find this association mutually advantageous. The word commensalism is applied to animals living together in this manner.

Campanularian Hydroids. These colonies may be easily collected, being found attached to logs or seaweed, just at the level of low tide. The zooids may be stained with carmine solution for the purpose of making out the parts more easily. If there is time the pupils should note the following points:

Examine a specimen, natural size, kept in formalin. How does it resemble a hydra?

Do you find bilateral symmetry, either in the colony or the zooids?

Place a specimen in a watch-glass and examine it with a simple microscope. How many kinds of zooids do you see?

In the feeding zooids can you see tentacles, hypostome, and a thickened body in a protecting, bellshaped case?

In other longer cases in the axils of branches do you see a number of round masses?

These are really buds growing in the reproductive zooid. When fully mature, these masses float out at the top of the protecting case and swim away as small jelly-fishes.

Examine both kinds of zooids, using a compound microscope.

Summary of Drawings. (a) A Campanularian colony of natural size.

(b) A single feeding zooid slightly magnified.

(c) A single reproductive zooid slightly magnified.

Alternation of Generations. The jelly-fish which swim away from the reproductive zooid do not attach themselves to rocks, but remain free as long as they live. They are umbrella-shaped bodies, the mouth being at the end of the handle, their shape being like 
that of an inverted hydra, with a greatly overgrown foot forming the covering of the umbrella. These jelly-fish are often called medusæ, because in some similar forms the long tentacles around the edges of the umbrella covering are supposed to resemble the snaky locks of the mythical monster. The tentacles surrounding the umbrella of the Campanularian medusæ are not large, but they have at their bases minute spots connected with nerve-masses. These are thought to be eyes or
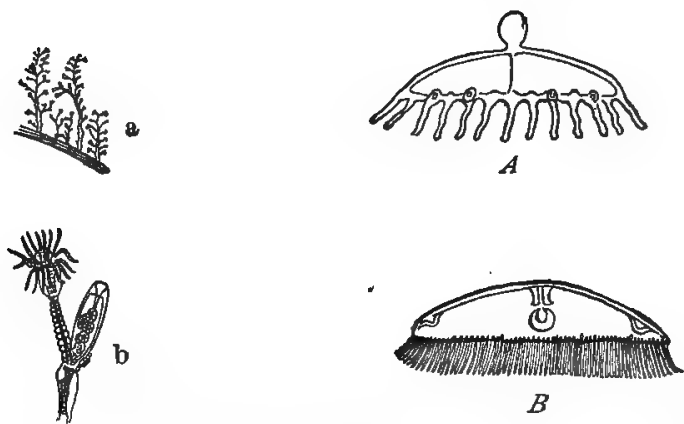

FIG. Ir3.-Medusæ of Campanularium Hydroid (Eucope diaphana), a, whole colony, one half natural size; $b$, single zooid magnified; $A$, young medusa magnified; $B$, adult medusa magnified. After Agassiz.

ears. These jelly-fishes swim through the water with a slow flapping of the umbrella edges.

After a time eggs are produced which float out into the water and produce, not jelly-fish, but the branching, fixed Campanularians. Thus the young resemble the grand-parents instead of the parents. The children of these young, however, resemble the jelly-fish. Such a phenomenon is not uncommon in the animal world and is called alternation of generations.

Scyphozoa. Besides the jelly-fish just described there are other free-swimming medusæ whose origin is 
somewhat different. The egg from one of these medusæ grows into a fixed, more or less hydra-like form which at maturity splits horizontally into a number of saucerlike disks. These finally break away and become the large jelly-fish we so commonly see in salt water (Fig. I 14 ).

Sea-anemones. In its cylindrical shape, the position of its mouth and tentacles, and in possessing thread-

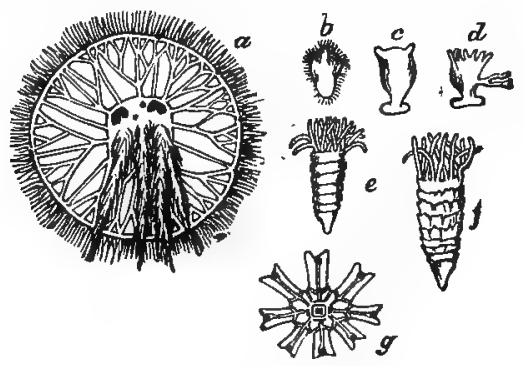

Fig. 114.-The Origin of a Scyphozoan Jelly-fish (Medusa aurita). $u$, adult; $b, c, d, e, f, g$, earlier stages.

cells, the sea-anemone resembles the hydra. The larger size of the sea-anemone makes it easy to study in localities where it can be used alive.

In the anemone the hollow body is traversed by radiating partitions called mesenteries. These serve to increase the area exposed to digested food. There is no hypostome present, and the internal cavity is reached by a passageway called the gullet.

Corals. The coral animals resemble the sea-anemone in structure. They differ chiefly in the fact that they deposit a hard skeleton. In the more common corals the skeleton shows septa corresponding to the mesenteries in the living animal. These animals live for the most part in colonies, the single individuals, or polyps, being connected at their bases in such a way that nutriment may pass from one to another. The examination 
of coral skeletons shows some facts concerning coral growth.

Examine the skeleton of Fungia. Remember that this is the skeleton of an animal something like the
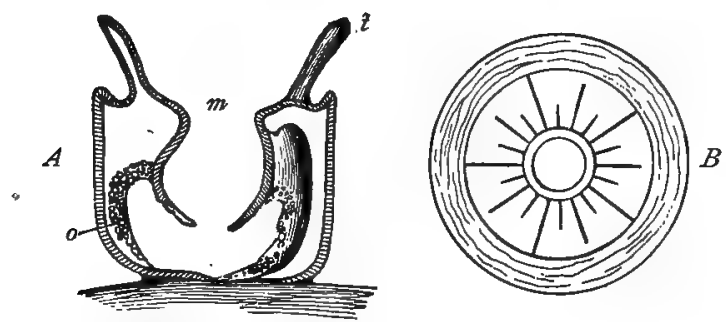

FIG. II5.-The Structure of a Sea-anemone. $A$, longitudinal section; $B$, transverse section; $m$, mouth; 0 , eggs; $t$, tentacle.

sea-anemone. What are some peculiarities of this skeleton?

Examine pieces of Galaxea skeleton. How does Galaxea differ from Fungia?

Count the septa in several tubes of Galaxea. How many? The parts of the tubes projecting above the general structure are called the thece.

Examine a branch of Madrepora. How does this differ from Fungia? from Galaxea?

Do you find thecæ and septa in Madrepora?

Were all the polyps of the same size?

How did the branches in Madrepora arise?

Were the lateral polyps connected with the central polyps? Use branches sawed longitudinally to show this point.

How did the lateral polyps arise in the course of growth?

How did the colony develop from a single polyp ?

Summary of Drawings. (a) Fungia skeleton, natural size.

(b) Galaxea skeleton showing several tubes $\times 3$. 
(c) Two tubes of Galaxea skeleton with outline sketch of the polyps that built the skeleton as you think they may have appeared $\times 5$.

(d) Branches of Madrepora skeleton, natural size.

(e) Longitudinal section of branch of Madrepora skeleton.

Other Coral-like Animals. There are many other kinds of corals and coral-like animals. The red coral of commerce is produced by polyps which deposit the solid matter in such a way that no traces of septa show in the skeleton. Something like these red-coral polyps are those which deposit a horny substance instead of calcareous matter, forming the sea-fans, sea-pens, and other similar growths of tropical regions.

Characteristics of the Colenterates. The Cœlenterates may be said to be animals having hollow cylindrical bodies provided with a single opening at one end. This opening is commonly surrounded by tentacles and these are provided with nettling-cells.

Classes of Cœlenterates. Animals like the hydra, having the whole body-cavity used as a stomach, and bearing a hypostome at the mouth-end of the body are called Hydrozoa.

Sea-anemones and coral polyps have the hypostome inverted to form a gullet. Radiating partitions or mesenteries are found in the body-cavity. These animals are called Actinozoa.

Our largest jelly-fishes, briefly described on page 133. are called Scyphozoa.

Laboratory Exercise for Review. Using specimens in numbered bottles or boxes, as indicated on page I I 3, write in note-books, or on paper, as fully as you can concerning the topics indicated below. Specimens not previously seen by the pupil are especially valuable for this work. *

* Of course all these activities cannot be inferred correctly from structure in every case, but the attempt to make the inference is valuable, and success is more frequent than failure. 
I. Habitat.

2. Mode of Locomotion.

3. Mode of Breathing.

4. Kind of Food Used.

5. Classification.

Topics for Reports. The Portuguese Man-of-war. Sea-anemones. Coral Islands. The Origin of Atolls. Coral Reefs. How Corals Have Helped to Build Florida. The Origin of Plants and Animals on Coral Islands. Examples of Alternation of Generation. Commensalism. Colonies. Experiences while Collecting Colenterates. Parasitism. Symbiosis.

\section{VOCABULARY.}

Cam pan u la'ri an (Lat. dim. of campana, a bell), a kind of hydroid whose feeding zooids live in a bell-shaped case.

Com men'sal ism (Lat. cum, together, and mensa, a table), a state of living together for mutual advantage, as in the case of the hermit-crab and hydractinia.

Her maph'ro dite (Gr. Hermaphroditos, the son of Hermes and Aphrodite), having both male and female reproductive cells in the same animal.

Hy'dranth (Gr. hydor, water), one of the nutritine zooids of a hy. droid colony.

Hy'po stome (Gr. hypo, under, and stoma, a mouth), the part of a hydroid animal bearing the mouth at its summit.

Las'so cell (Lat. laqueus, a snare), a sensitive nettling-cell containing a coiled thread.
Me du'sa (Lat. Medusa, one of the Gorgons), an umbrella-shaped, free-swimming jelly-fish.

Mes'en te ry (Gr. mesos, middle, and enteron, intestine), one of the radiating walls in the body of a polyp.

O'vum (Lat. ozum), an egg.

Pol'yp (Gr. polys, many, and pous, foot), a feeding zooid of a hy. droid or coral-forming colony.

Sep'tum (Lat. septum, a fence), a radiating portion of a coral skeleton.

Ten'ta cle (Lat. tento, to try to hold), a feeler around the mouth of a cœlenterate.

The'ca (Gr. theke, a case), a portion of a coral skeleton.

$Z_{0}^{\prime}$ oid (Gr. zoōn, an animal, and oid, like), one of the members of a colenterate colony. 


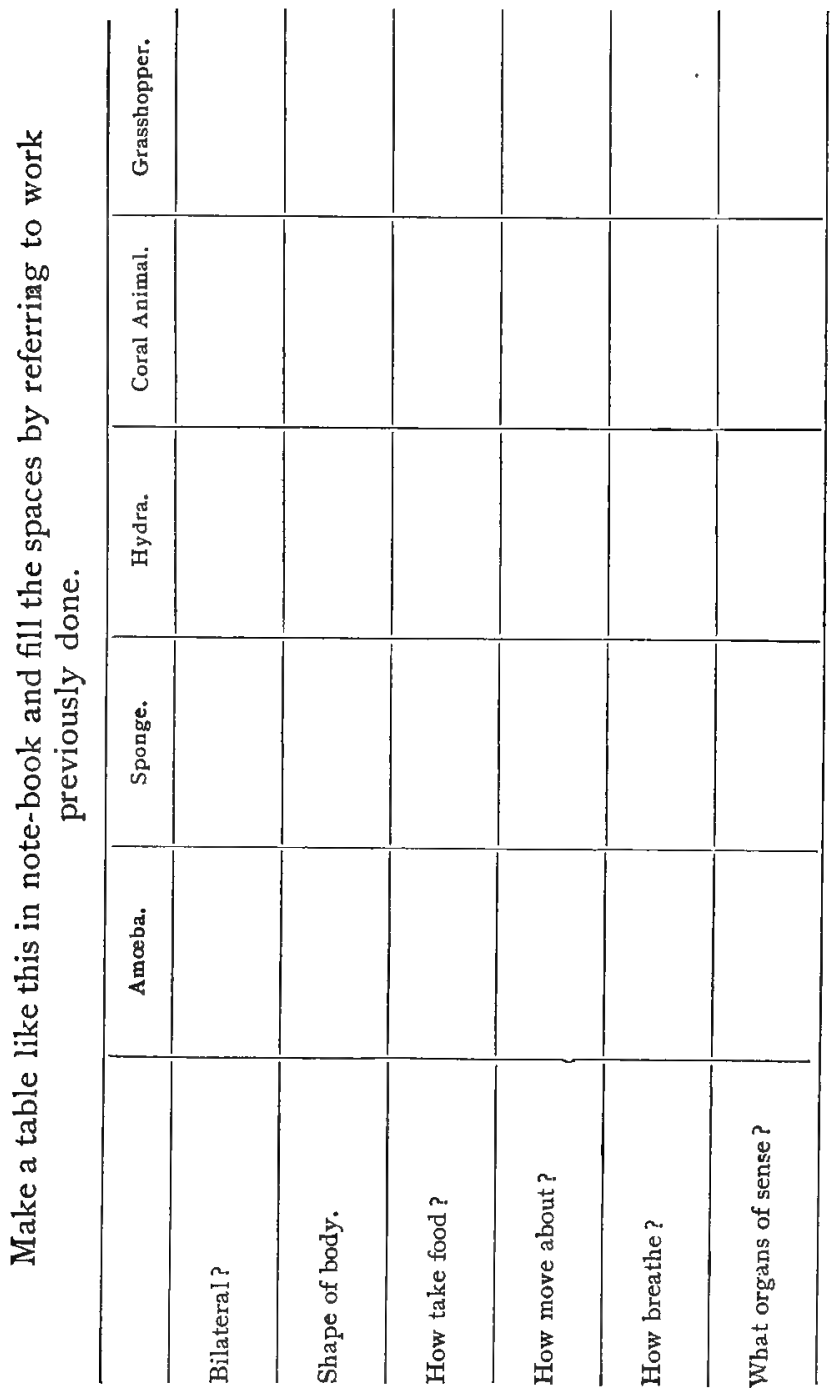




\section{CHAPTER XIII.}

THE STARFISH AND CLOSELY RELATED ANIMALS.

The Starfish. The common starfish (Asterias vulgaris) may be easily found at low tide along the New England coast. To obtain the dried specimens for study, kill the animal by immersing it in warm fresh water. It may then be preserved by hardening it in alcohol or in boiling water and drying quickly, or by packing in salt. If possible get a living starfish and place it in a pail of salt water.

How does the starfish move? Observe the ambulacral feet.

Do you see the eye-spot at the end of each arm ?

Where is the madreporic body?

Is the animal bilateral?

Is each ray bilateral?

Are all of the rays of the same size? How do you explain any differences?

Are any of the spines movable?

Which is the oral and which the aboral surface?

With a magnifying glass examine the aboral surface for the purpose of finding the minute pincer-like bodies called pedicellarice.

Can you find projections of the skin used in breathing ?

Examine a dried specimen.

Are all the spines of the same shape?

How many kinds of spines do you find?

How many kinds of plates do you find? 
The walking, or ambulacral, surface is called the ambulacral area.

How many rows of ambulacral plates in each ray? How many rows in all ?

Do the ambulacral feet pass through these plates or between them?

The regular plates situated on either side of the ambulacral areas are called interambulacral plates, and the surfaces they cover are called interambulacral areas. How many rows of interambulacral plates do you find in each ray? How many rows in all?

How do the spines on these plates differ from those on the irregular plates of the aboral surface?

The plates on the aboral surface may be called body-plates. Can you find the single plate with its ambulacral foot at the end of each ray?

With a partly dissected specimen, which has been prepared by hardening in alcohol, laying open the upper or aboral surface of one of the rays and removing the digestive organs, notice the ampullæ or internal enlargements of the ambulacral feet. What is the use of the ampulla in locomotion?

These ampullæ are connected with a tube running along the ray in the angle made by the two rows of ambulacral plates. Trace this tube, which supplies the ambulacral feet with water, up to the tube running around the mouth. Find the stone canal connecting this tube with the madreporic body. What do you think may be a use of the madreporic body?

Examine portions of the skeleton of a starfish which have been decalcified by allowing them to soak in about ten per cent. nitric acid for a few days. Compare these with similar portions which have been treated with weak caustic potash until the fleshy matter has been removed. Are the plates formed inside of the fleshy skin or outside of it?

Write resemblances and differences for starfish and hydra. 
Compare this starfish with the brittle starfish.

Summary of Drawings. (a) Sketch of a living starfish.

(b) Sketch of a portion of an ambulacral area showing the relative positions of the plates and the openings for the ambulacral feet.

(c) Cross-section of an arm to show the relative position of feet, water-tube, plates, and spines.

(d) Ambulacral feet with ampullæ.

(e) Sketch of a brittle starfish.

Activities of the Starfish. The starfish belongs to the sub-kingdom Echinodermata, anirrals having hard plates in the skin.

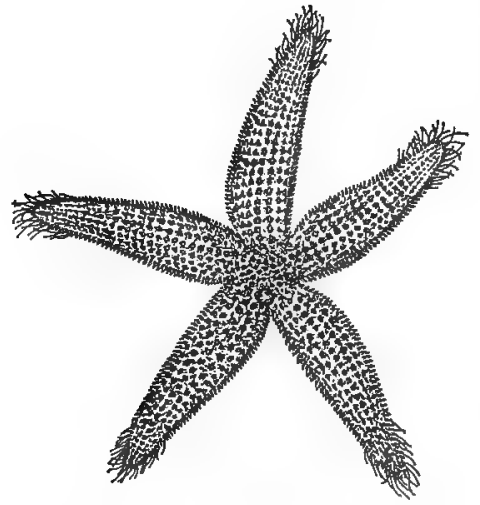

FIG. 116.-A Starfish. After Agassiz.

Their movements are slow and all their activities are of a low order, yet they a r e more highly specialized than the Cœlenterates $\mathrm{w}$ e have just been considering.

Taking F o o d. The mouth of the starfish is situated on the under side, hence this side is called the oral side. There are no teeth, yet the starfish lives on oysters, clams, mussels, and other hard-shelled animals. The stomach is an elastic bag which fills the central part of the body and extends into all the arms or rays, thus making the shell simply a protection for this branching, walking stomach. This stomach secretes a fluid which partially paralyzes its prey. If a mussel is too large to pass through the mouth, the starfish stretches a part of its stomach outside of its body, and enfolds its 
victim until the shell opens and the contents can be sucked out.

Nutrition. Outside the stomach, throughout the cavities in the rays there is a glandular mass, the liver, which secretes a digestive fluid and pours it into the stomach. Here the food is digested and the nutriment absorbed. There is a very short intestine opening opposite the mouth. It is so small in diameter that the waste of the food cannot pass through it, and must therefore be ejected through the mouth.

Respiration. For the most part breathing takes place at all parts of the body, but there are folds of the skin over the aboral surface which are supposed to act somewhat like gills.

Reproduction. The reproductive organs, of which there are two in each ray, lie on the floor of the ray; their ducts opening in the angles between the rays. These openings are called the genital openings. After the eggs of the female and the sperms of the male have been discharged into the water, the eggs are fertilized by the sperms. From these fertilized eggs develop young starfish, which are at first bilateral, and bear no resemblance to their parents.

Discovery. The only specialized sense-organs are the eye-spots at the ends of the rays. The nervous system consists of a nerve around the mouth with a branch extending into each ray and ending in the eye-. spot just mentioned. The sense of feeling is apparently dull, and the starfish seems to suffer no hardship by the deprivation of one or two of its rays, which quickly grow again when once broken off.

Movements. The starfish and its relatives have a method of locomotion very different from other animals. Along the oral surface of the rays are the cylindrical tube-feet, or ambulacral feet, bearing suckers at their extremities. These tubes extend through the skeleton into the body-cavity, where they enlarge into bulbs called ampulle. Each bulb connects by a small tube 
with a larger tube running lengthwise of the ray, and this in turn connects with a tube surrounding the mouth. With this oral tube the radiating tubes all unite and from this there extends the stone canal (another tube) reaching to the madreporic body on the aboral surface. The ambulacral feet have muscular walls. The madreporic body is pierced with minute holes through which water can enter the water-system.

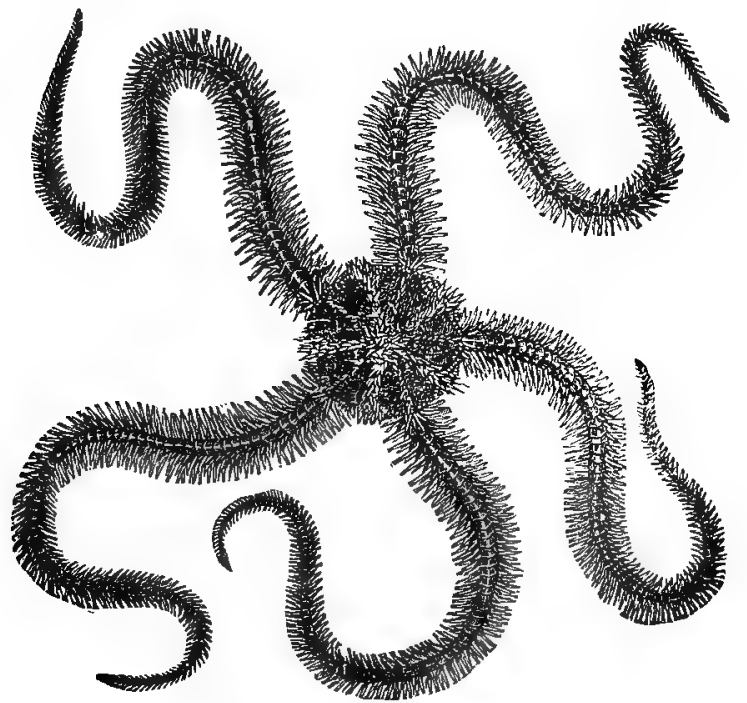

FIG. II7.-A Brittle Starfish.

When the starfish wishes to advance, some of the ambulacral feet are elongated in the direction of progression by squeezing the ampulla and forcing the water into the feet. When the feet are fully extended the sucker at the end of each foot fastens itself to the rock, or other support near, and the longitudinal muscles of the tube contract, shortening the ambulacral foot and pulling the starfish to the rock. 
The Sea-urchin. If possible get a living sea-urchin and watch its movements in a pail of salt water, or better, in a salt-water aquarium.

What is the shape of the body?

Do you find oral and aboral surfaces?

What is the shape of the spines? How do they move?

Do you find the ambulacral feet?

Examine the mouth and notice the manner of feeding.

Hold the living animal in the hand and observe its mode of locomotion.

Place it upside down in the water and watch it.

Does it have bilateral symmetry or any kind of symmetry?

Examine the test or shell which has been freed from spines.

How can you tell the ambulacral from the interambulacral plates?

How many rows of each kind of plates do you find ?

What is the shape of these plates?

Look at broken pieces of tests.

Do you find a single plate or tentacle at the end of each ambulacral area, as in the starfish (ocular plates)?

At the ends of the interambulacral areas do you find the genital openings? How many do you find?

The small plates, in the circle surrounded by the genital plates, correspond to what plates in the starfish?

Do you find the madreporic body?

What changes would have to occur in the body of the starfish to give it the form of the sea-urchin?

What parts of the sea-urchin are homologous with parts of the starfish?

Examine the teeth. How many teeth do you find?

Write resemblances and differences for starfish and sea-urchin.

Compare a sea-cucumber with a sea-urchin. 
Summary of Drawings. (a) A living sea-urchin, natural size.

(b) A single spine showing mode of attachment to the shell.

(c) Several ambulacral and interambulacral plates. (d) External form of a sea-cucumber.
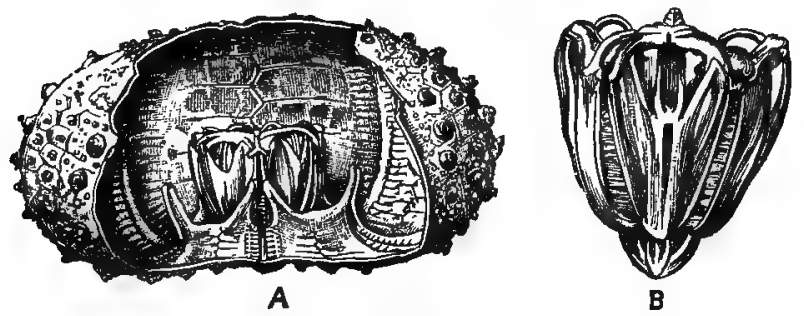

FIG. II8.-The Structure of a Sea-urchin. $A$, interior of shell; $B$, teeth.

Activities of the Sea-urchin. The activities of the sea-urchin resemble those of the starfish. One peculiarity deserves mention. The mouth of the sea-urchin

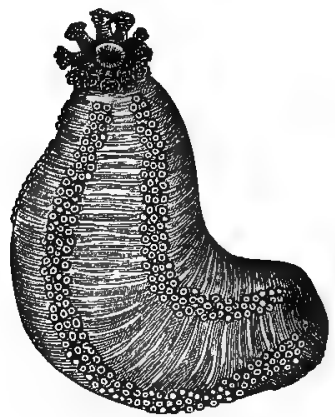

Fig. Irg.-A Sea-cucumber. is provided with a complicated arrangement of teeth, five in number, uniting at a point. This whole apparatus is called Aristotle's lantern in honor of the philosopher who first described it. With these teeth and possibly by the aid of oral secretions the sea-urchin is enabled to burrow into solid rock.

Other Echinoderms. Seacucumbers of many kinds, the worm-like Synapta with it s anchor-shaped plates, the great variety of starfishes, sand-dollars, Crinoids both fossil and present, with other less common forms all bear a striking resemblance to the two forms studied. 
Characteristics of Echinodermata. This sub-kingdom enjoys the distinction of being the most exclusive division of the animal kingdom. These animals secrete bony plates in the skin; they have marked radiate structure, almost always being divided into five radiating parts. With the radiate structure we may also trace a bilateral condition. (In the case of the starfish this condition may be seen by drawing a line through the madreporic body and the opposite ray.) The water-system with its ambulacral feet is peculiar to this sub-kingdom. All are marine.

Topics for Reports. The Burrowing of Sea-urchins. Sea-cucumber as Food. Radiate Structure. Where I Have Seen Echinoderms. The Senses in a Starfish. Young Starfishes. Basket-fish. Stone-lilies.

\section{VOCABULARY}

Ab o'ral (Lat. $a \bar{b}$, from, and os, mouth), the surface opposite the mouth.

Am bu la'cral (Lat. ambuclo, to walk about), a word applied to the walking areas of Echinoderms.

Am pul'la, pl. ampullo (Lat. ampulla, a flask), the enlarged end of one of the tube-feet of an Echinoderm.

De cal'ci fy (Lat. de, from, and calx, lime), to remove the calca. reous matter.

Gen'i tal o pen ings, the openings for the passage of eggs and sperm in starfishes and sea-urchins.

Mad re por'ic body, a hard plate pierced with holes through which water filters into the tubefeet of a starfish or sea-urchin. o'ral (Lat. os, the mouth), pertaining to the mouth.

Ped i cel la'ri a (Lat. pediculus, a small foot or stalk), a minute pincer-like organ on the skin of an Eclinoderm.

Ra'di ate (Lat. radius, a ray), having the parts regularly arranged around a centre. 


\section{CHAPTER XIV.}

\section{THE EARTHWORM AND HIS WORK.}

THE earthworm or angleworm belongs to the subkingdom Vermes. It also belongs to the class $A n n u$ lata, which includes the most highly organized and most intelligent animals belonging to this sub-kingdom. In studying it we must note how it differs from any or all of the Arthropoda, and discover if possible why naturalists have not classified it with this sub-kingdom.

The earthworm may be easily observed alive by placing several individuals in a glass jar with loam and dead leaves, and occasionally feeding them with bits of meat or vegetables.

Is the body bilateral ?

Can you distinguish a head ? a head end? a neck ? a dorsal and ventral surface?

Is the body anywhere flattened?

Are there any divisions in the body like those in the Arthropoda?

Are there any jointed appendages?

Do you find any eyes? Is the worm sensitive to touch ? to light? to strong odors ? to irritating fluids ?

While the worm is feeding can you see any teeth? Do you see something which looks like a proboscis?

Do you see the red blood-vessel near the dorsal surface?

Earthworms tanned by the use of chromic acid make good specimens for class use. They may be prepared as follows: Place the worms in dilute alcohol for three or four days and then transfer them to strong aicohol, 
where they may remain for several weeks. Then put them in a one per cent. solution of chromic acid for five or six days. Remove them from this solution, wash them thoroughly in water and place them in a dish with turpentine, allowing them to remain there for a few days longer. They may then be dried, when they are ready

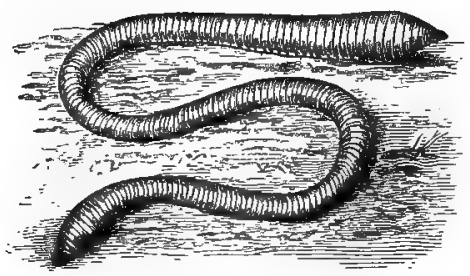

Fig. I20. - An Earthworm.

for use. The worms should be spread out in flatbottomed dishes during the processes of tanning. With specimens thus prepared or simply hardened in alcohol, the class should write the answers to the following questions:

Do the worms all have the same number of segments?

Do you find several rings together which seem to be enlarged? This is the clitellum or reproductive girdle.

How many segments from the clitellum to the head end?

Is the body of the angleworm smooth? Does it appear more rough when the finger is moved in any special direction? The roughness is caused by bristles or setce. Do they all point in the same direction?

How many rows of setæ along the body? How many setæ on a single segment?

Does the worm have an internal skeleton? Does a thin cuticle separate easily from the body of a worm which has been soaking in water for a time?

Can you make out the shape of the segment in front of the mouth?

Summary of Drawings. (a) The whole worm, natural size.

(b) The segments near the head $\times 6$. 
(c) A cross-section of one segment to show the setæ $\times 6$.

Taking Food. The earthworm has neither hard mouth-parts for biting food nor a tube for sucking. Its mouth is simply a hole bounded by fleshy lips. The segment in

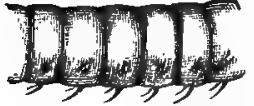

FIG. 121. - A Worm's Setæ. front of the mouth forms a sort of proboscis or elongated upper lip which is used to push the food into the mouth. The food consists of fallen leaves or any organic matter found in or around its burrow. Decaying vegetable matter forms the greater part of its food, and if it cannot get decayed leaves it can pour out of the mouth a fluid which makes the leaf decay and blacken at once. Since the worm gets much of its food beneath the surface of the earth, it builds a burrow for its home. Such a burrow is a plain hole usually slanting from the surface down to a depth of four or five feet, always extending below the frost of winter. At the bottom of this hole is a small round room carefully lined with stones or seeds. In making this burrow the worm not only eats the vegetable matter

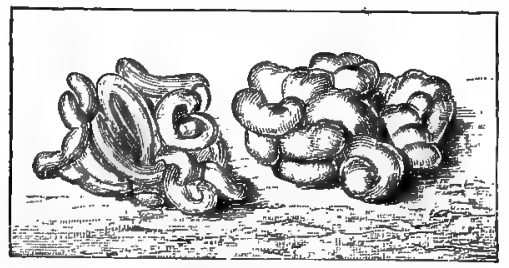

FIG. 122.-Worm-casts.

in the ground but swallows the earth as fast as he excavates it, thus mixing his food with loam.

Nutrition. The worm has no teeth and no jaws; so his food passes down the gullet or cesophagus to an enlargement of the alimentary canal called the crop. 
Next it goes on to the gizzard, which is filled with little stones to make a mill for grinding the food. After being ground, the food passes into the intestine, where the nutritious matters are taken into the blood and carried to the tissues of the body, while the part which cannot be digested is cast out at the end of the body, usually near the opening of the worm's burrow. The blood which carries the nutritious matter to the parts where it is needed is of a reddish color, but the color is in the liquid part of the blood and not in the corpuscles, as is the case in our own bodies.

Respiration. An examination of the earthworm's body reveals neither spiracles nor gills. In fact it has no breathing organ, but takes oxygen from the air at all parts of its skin and sends out or excretes carbon dioxide and other impurities at the same time. The blood-vessels are so near the surface that the necessary interchange of gases can easily take place as long as the worm's skin is moist. Worms cannot live long in the sunlight or in dry sand because they cannot breathe under such conditions.

Reproduction. On the under side of the fourteenth and fifteenth segments in a common species are to be found some small openings which lead to the ovaries or egg-producing organs. Several segments in front of these, there are tiny holes in the grooves between the segments. These open into receptacles containing the male cells or sperms.

When the time for depositing eggs arrives certain glands of the clitellum become very active and pour out on the surface of the body a fluid which hardens into a tough membrane, making a girdle around the body, the reproductive girdle. A jelly-like liquid remains between the girdle and the body while it is gradually pushed forward. When the girdle passes the openings to the ovaries the eggs are discharged into it, and when it passes the segments from nine to eleven the sperms pass into the fluid with the eggs. The 
girdle then passes over the herul and closes at boulh encls, forming it capsule continining the reprouluctive cells. Here fertilization take's plice, and the chiss hatch finally into little worms which rippially grow by the addition of new segments.

Discovery. We fincl no cyes, ears, or other organls of sense on examining the earthworm, yet we know that he has to some slight extent a sense of smedl, for he enjoys the smell of onions, cabliages, and othere dainty articles of earthworm dict. l'ossibly, tor, he can hear a little, for he is disturbed by sumals which shake the earth near his burrow, though utterly disregarding the loulest noises makle in the air alueve him. Although without cycs lec can tell diaylight from rialiness; the power of doing this is saicl to resirle in the first few segnents of his body in which his brain is found. He is probably somewhat sensitive on light in all segments of his bocly.

His sense of touch is keenest of all and, indecel, his whole body seems to lxe at sort of fccler.

Movements. The earthworm doubtless crmtrols his own movements to a considerable extent. Ile even shows signs of intelligence, thomgll of at very low oreler. The most brilliant thing the citrtliworm eloes is to plutr up the opening of his burrow to hirle it from his encenics. For this purpose he selects his matcrial with some care.

Leaves, bits of paper, twigs, wool, and sometimes stones are used by the worm to make this plus, or dour., to his hole. He seizcs with his lips the sulpstances to, be used and fits them neatly to the mouth of $11 x$. burrow. Whan he uses a leat he elrigre it in by the: part best suited by its shape to fit the place intenderl for it. Mr. Darwin noticesl that sometimes a wrirm would let go a leaf and then try a new way of jullin! it into his hole.

The worm also moves up ind down his burow at will, and if necessary he call travel sonnc distance from 
home, crawling over very difficult roads and even scaling perpendicular walls. The controlling mechanism for these movements lies in a small brain situated above the cesophagus and hence sometimes called the supracesophageal ganglion, and in a series of ganglia lying under the alimentary canal, a pair in each segment. These ganglia are connected with each other and with the brain by nerves, and branches ramify from them to all parts of the body. This arrangement of nerve-masses along the ventral portion of the body is decidedly advantageous to a crawling animal, giving him constant information concerning the ground over which he travels.

Locomotion in the earthworm is accomplished by the use of three sets of muscles under the control of his nervous system. One set of muscular fibres runs lengthwise of the body, another surrounds each ring, and a third layer sends its fibres diagonally across the segments. When an earthworm wishes to go forward he fixes his setæ in the ground in such a way that his body cannot move backward, but will easily move forward. If, now, his body is already extended its full length, he contracts his longitudinal muscles, thus shortening his body and making it much thicker. He then contracts the circular muscles surrounding the segments, elongating the body and making it much smaller in circumference. Since the setæe prevent the body from going backward, it must move forward. The setæa are curved near the end to make them more useful in holding the body in place. The diagonal muscles are used in moving the body from side to side.

The Usefulness of the Earthworm. In spite of his apparent insignificance the earthworm is the farmer's loyal friend. $\mathrm{He}$ is a ploughman of ancient lineage and his work is most efficient. He brings to the surface fresh subsoil to replace the exhausted layer which the farmer has been cultivating. He grinds up organic matter and leaves it finely powdered in his castings for 
the use of plants. He renders the earth porous for the better spread of moisture and the more rapid pushing of plant-roots. He buries rocks far beneath the soil and covers old fields with fresh loam. All pupils should read Mr. Darwin's book entitled "The Formation of Vegetable Mould."

'The Earthworm's Relatives. Along with the earthworm are classified many animals which outwardly bear no resemblance to him. It sometimes seems as if naturalists reserved the sub-kingdom Vermes as a sort of waste-box in which to place all creatures not easily classified elsewhere. The strange ways of the Vermes must be studied by the help of other books. 


\section{CHAPTER XV. \\ MUSSELS AND SNAILS.}

The Fresh-water Mussel (Anodon or Unio). These mussels may be easily obtained on the sandy bottoms of fresh-water ponds or streams. A few should be placed in an aquarium which has a few inches of sand on the bottom. They do well without feeding. Littleneck clams make good individual specimens for the work here outlined. Boil the clams to harden them.

Notice the color and shape of the shell. How many parts has it?

Do you see any markings on the outside? What do these seem to indicate?

Does the shell seem to be covered? Compare it with a dried shell. Is the entire surface covered? How do you explain your observation? The bared projection is called the umbo.

How are the two parts of the shell held together? Is the hinge you find at the dorsal or ventral margin of the valves? How can you tell?

In what direction does the animal move? How fast?

Is the umbo nearer the anterior or the posterior end? How can you tell?

Find the right and left valves.

Observe the foot. How is it used?

Is it at the anterior or posterior end of the body?

At the end opposite the foot find the fringed openings. When the shell is open and the animal is feeding comfortably, color the water directly in front of these openings with a little indigo or cochineal solution 
introduced by a pipette. What do you learn from this concerning the manner of feeding ?

What happens when you touch the animal on its shell and at different places on its fleshy parts when it is feeding quietly?

Examine a mussel or clam which has been boiled, or hardened in alcohol.

Press the valves together and quickly release them. Why do they fly open again?

When the mussel was alive what held the valves together? Explain the manner of opening and closing the shell.

Place the mussel on its side in a dish of water so that the dorsal portion is away from you. Is the anterior portion of the mussel near your right hand, or your left hand?

Carefully remove the upper valve without disturbing the soft parts beneath. Have you removed the right or left valve?

The membrane lining the interior of the shell is the mantle which secretes the material of which the shell is formed. Does this mantle line the entire shell? Is it of equal thickness in all parts?

How many muscles held the valves together?

On a dry shell do you find the marks which show where the muscles were attached? Do you find the muscles themselves?

Determine which is the posterior adductor muscle and which is the anterior adductor muscle.

Find the mark which the mantle makes where it adheres to the inside of the shell. Call it the pallial line. Do you find any other markings on the inside of the shell? Compare mantle outside of pallial line with that above. What is the relation of mantle to shell?

Raise the mantle and notice the striated leaf-like gills. How many do you find?

Look for the labial palps near the anterior portion 
of the gills. How many do you find? The mouth is between the palps.

Examine the ventral and dorsal passages of the siphon. Are they connected? Into what cavity does each lead?

See if you can find the heart near the dorsal margin.

Have you found that the mussel has a head? What organs of sense have you found?

Examine mussel-shells which have been burned for some hours in a hot fire. Compare with them some

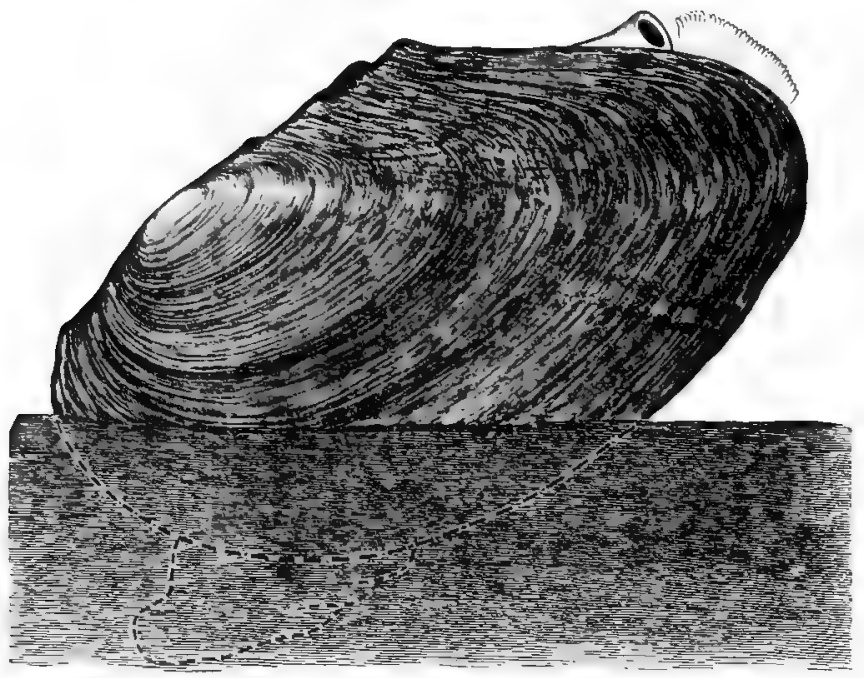

FIG. I23.-A Fresh-water Mussel (Anodon) Showing Position of Foot and Siphons.

shells which have been immersed in weak acid for several days. Examine, also, oyster-shells which have been prepared in the same way. Describe the structure of a shell.

On the dorsal margins of the valves of a shell find 
the hinge-teeth if there are any. How many teeth do you find on each shell?

Compare the shell of the common salt-water clam (Mya Arenaria) with that of the mussel (Unio). How do the teeth and hinge-ligament differ ?

How do the markings on the inside of the shell differ ?

What differences in the structure of the animals do these markings indicate?

In the same manner compare the shell of oysters, pectens, and other bivalves.

Write a description of a shell you have not previously seen and compare your description with that given in Woodward's Mollusca or a similar book.

Summary of Drawings. (a) Sketch of a living mussel showing foot and siphons.

(b) Cross-section of valves showing action of hinge.

(c) Inside of shell showing all muscular impressions and the pallial line.

(d) Sketch of mussel in its shell.

(e) Cross-section of the body of the mussel near the umbo.

$(f)$ Shells of several bivalves.

Activities of the Clam or Mussel. Feeding. We have already noticed currents of water flowing in and out of the siphon at the posterior end of the body. The water enters by the ventral opening and goes out by the dorsal opening. The dorsal and ventral passages are separated, and this separation continues through the body of the clam, dividing it into two chambers, the dorsal or cloacal chamber and the branchial or gillchamber. In many marine clams the mantle-edges unite again below the branchial siphon, but in the fresh-water clam they are free along the ventral border. As water enters the lower siphon it brings with it food and oxygen into the branchial chamber. In this chamber hang the two pairs of ridged leaf-like gills bearing cilia which by their movements keep the currents of water in motion. These cilia also select from 
the water the minute animals and plants which nourish the clam. These bits of food are collected along the ridges on the gills and thence passed to their ventral edges, on each of which there is a groove leading to the mouth. Along this groove the food passes, whipped on by the cilia, until it enters the mouth, which is

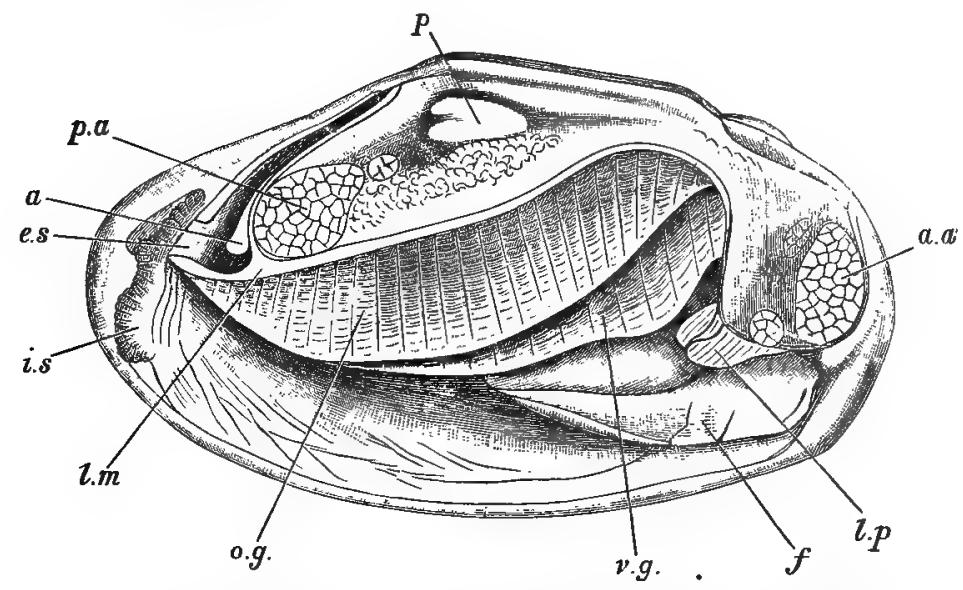

FIG. 124.-Fresh-water Mussel with One Valve Removed. p, pericardium; p.a., posterior adductor muscle; a.a., interior adductor muscle; $a$, anus; e.s., exhalent siphon; i.s., inhalent siphon; $2 . m$., cut edge of mantle; $0 . g^{*}$, outer gill; $v_{. g}$, inner gill; $f$, foot; l.p., labial palps.

situated between the labial palps at the anterior end of the body.

To understand what becomes of the water that brings in the food we must remember that each gill is a fold of membrane pierced with tiny holes. In order to pass from the branchial chamber to the cloacal chamber the water must pass through these holes. A cross-section of a gill has a V shape, and the water goes through the sides of the $\mathrm{V}$ into the opening above and thence passes out of the cloacal chamber by the upper siphon, 
Nutrition. In the clam the various processes concerned in nutrition are more distinctly separated than in any of the other sub-kingdoms below the Arthropoda. When the food enters the mouth it passes down the throat to the stomach. The dark portion of the body surrounding this alimentary canal is the liver, which secretes digestive fluids and pours them on the food. The intestine beyond the stomach passes directly

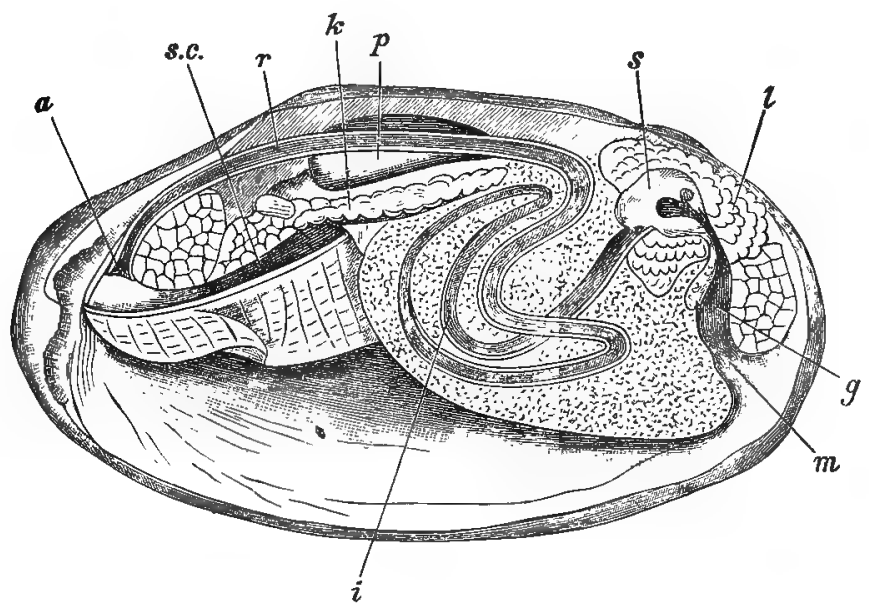

Fig. 125.-Digestive Tube of Fresh-water Mussel (Anodon'. m, mouth; $l$, liver; $s$, stomach; $i$ and $r$, intestine; $a$, anus; $p$, pericardium; $k$, kidney; s.c., chamber above gills; $g$, gullet.

through the heart and opens into the cloacal chamber in the current of water which passes out of the upper siphon.

The digested food is taken up by the blood and carried to all parts of the body by the circulating system. The most important organ of this circulating system is the heart, which is situated just below the hinge. It has a ventricle and two auricles.

In its course, part of the blood is purified by the gills 
and passes from these organs to the auricles. Part of the blood also flows through the renal organs, which take from the blood (excrete) the nitrogenous waste matters and empty them into the outgoing current of water. The ventricle forces the blood, constantly coming to the auricles, away from the heart all over the body.

As in other animals, the separate cells take from the circulating liquid the substances necessary to produce

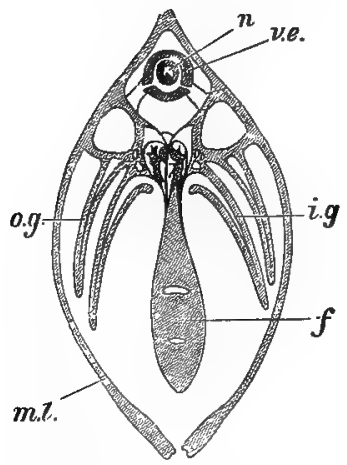

FIG. 126.-Cross-section of Anodon. $n$, intestine; v.e., heart; i.g. and o.g., gills; $f$, foot; m.l., mantle.

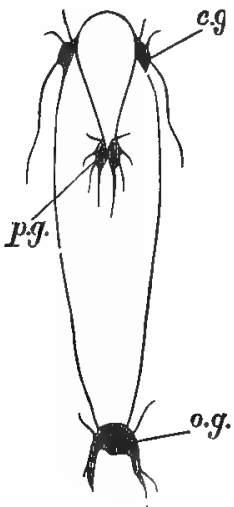

FIG. I27.-Nervous System of Anodon. c.g., ganglia near the mouth; $p . g$. , ganglia of the foot; $0 . g$., ganglia of the posterior adductor.

more cells like themselves or to manufacture intercellular structures. The, cells of the mantle secrete carbonate of lime, which forms in layers on the inside of the shell and along its edges, thus increasing both its thickness and its size. If the mantle be irritated by the introduction of minute particles of foreign matter or by disease the secretion of carbonate of lime at a definite point is hastened and a pearl is formed.

Respiration. As the water passes through the gills it flows over and around many blood-vessels, through 
whose walls the interchange of gases common in all breathing takes place.

Reproduction. The eggs of the fresh-water mussel pass from the ovaries to the cavity of the outer gill, where they hatch. The number of young is enormous. They remain for a time within these gills and then pass out to grow or to be destroyed, as the case may be.

Discovery. The senses of the mussel are not acute and there are no special organs of sense. Touch is more acute in the foot and at the margins of the mantles, as might be expected, these being almost the only exposed parts. There is a so-called ear-sac in the foot, but it is not probable that the mussel can hear.

The nervous system consists of three pairs of ganglia connected by nerves. One pair form a sort of brain (the supracesophageal ganglia), one pair lie directly under the posterior adductor muscle (the visceral ganglia), and the third pair are imbedded in the tissue where the foot joins the body (pedal ganglia).

Motion. The opening and closing of the shell at will is brought about by the action of an elastic hingeligament and a pair of adductor muscles. When the muscles contract the shell is closed; when they relax the hinge-ligament acts like a door-spring and forces the valves apart.

The foot is protracted partly by muscular activity and partly by increasing its size by pumping its vascular vessels full of blood. When left lying on its side in the aquarium the animal rises to an erect position by sinking its foot into the sand. It plows its way through the mud or sand by muscular contractions of this foot.

The Garden-slug. Obtain some garden-slugs, or, better still, some of the larger slugs found in damp cellars or green-houses. Keep them in a box with plenty of moisture and feed them with cabbage-leaves and bread. Watch the mode of locomotion. Allow the animal to crawl on a piece of glass and watch the 
movements of the foot. Examine the trail of mucus left as the animal advances.

Do you find the place from which this mucus comes?

Do you find a head? a neck?

What organs of sense do you find ? Describe their position.

How does the slug feed? Has it a shell ? a mantle? On which side of the body is the breathing orifice?

How often does the slug breathe?

How often do you breathe?

Is there any relation between rapidity of breathing and rapidity of movement?

Do you call the slug's body warm or cold?

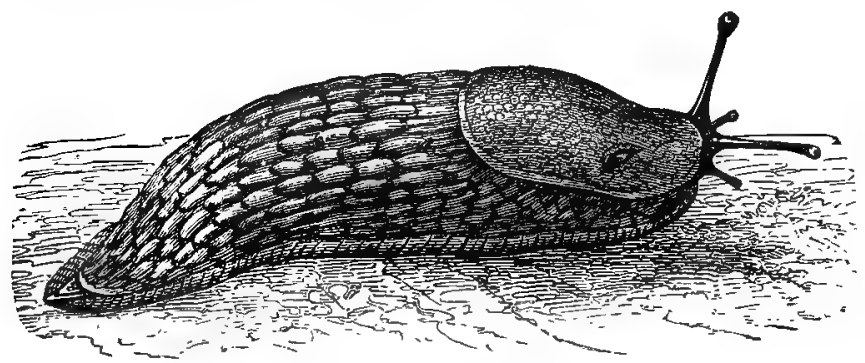

FIG. I28.-A Slug.

Does the rate of breathing have anything to do with the snail's temperature?

Write resemblances and differences for slug and freshwater mussel.

Sketch the slug as you see him.

Pond-snails. These animals are found in almost all ponds, crawling on dead leaves or aquatic plants. They may be easily kept in a jar of water for classstudy. Get some pond-snails and keep them in a jar of fresh water. Watch all their movements.

Write resemblances and differences for snail and slug. Note all points mentioned in regard to slug and mussel. 
Can a snail leave its shell and return?

Can it close its shell?

Examine different kinds of snails for this characteristic.

Do all the snails you have seen breathe in the same way?

Can a snail swim?

Can it walk on the surface of the water?

Is the snail bilateral?

Compare a land-snail with a water-snail.

Study several shells and notice the sutures, the apex, the spire, the whorls, the lines of growth, the aperture, and the lip. Compare these parts in snailshells of different kinds.

Notice all other differences and tabulate your observations. The columella is the axis of the spire. The piece which closes the snail's shell is the operculum.

Hold the shell with the apex upward. Is the aperture toward the right (dextral) or the left (sinistral) of the columella?

Is the aperture notched or entive?

Describe a shell from observation of the specimen and compare your description with that found in a standard work.

Summary of Drawings. appears while crawling $\times 3$.

(b) A shell of litorina or similar shell.

(c) A shell of purpura or a similar shell.

(d) A shell of a limpet.

(e) Right valve of an oyster.

(f) Various shells showing different structures.

Snail and Mussel. A comparison of the snail and mussel shows on the part of the snail a distinct advance in the collecting of organs of sense at the anterior portion of the body and the growth of a head there. The possession of a head with a brain and active senseorgans is apparently associated with the matter of foodsupply and feeding. So long as a soft-bodied animal 
can have all the food he wishes brought to him by currents of water there is no use for head, or eyes, or sensitive feelers. On the other hand, an animal which must forage for his food can do it more advantageously if he learns to walk head foremost. In order to make great progress in this way he must have some means of discovering obstacles in his pathway. Hence the necessity of feelers and eyes. In the struggle for food among animals the headward growth and specialization is a great advantage.

Active exercise in earning a living in competition with other animals which desire the same food not only

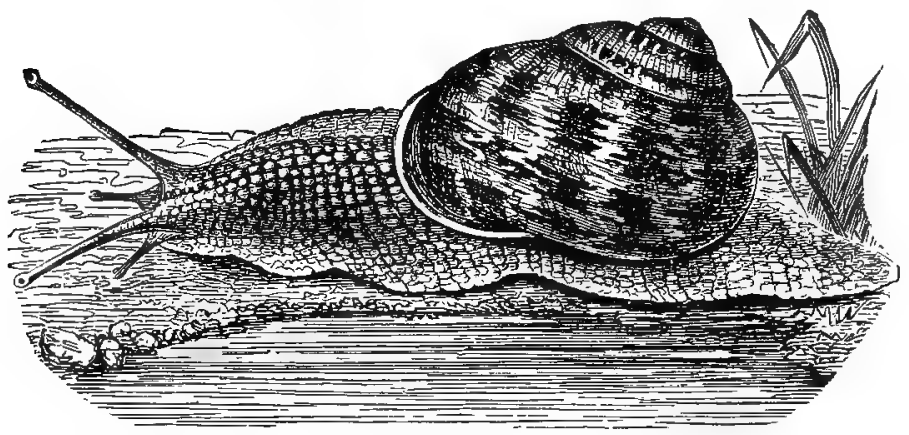

FIG. 129.-A Snail.

sharpens the wits but actually increases the physical development of those organs on whose activity intelligence depends, just as vigorous muscular exercise develops the parts trained.

Mussels and snails belong to the sub-kingdom Mollusca. The mussels, clams, oysters, and similar bivalves are members of the class Pelecypoda. These animals are sometimes called Lamellibranchiata because they have four leaf-like gills, and sometimes Acephala because they have no heads.

Univalves like the snails and the limpets, and slugs which have no shells, are classed as Gastropoda. 
Another important class of mollusks is the Cephalopoda. The squid belongs to this class, as do the

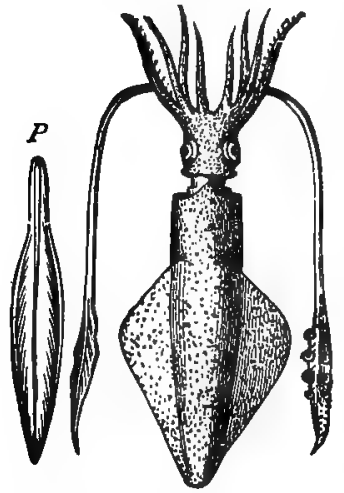

FIG. 130.-A Squid. $P$, its pen. octopus, the argonaut, and the pearly nautilus.

Characteristics of Mollusca. The name Mollusca is given on account of the fact that the bodies of these animals, excepting the shell, have no hard parts. In Mollusca the body is typically bilateral. There is a mantle present which in most cases secretes a shell which is as much a part of the animal as is the mantle itself. These shells increase in size as the animal grows, and . so exhibit lines of growth. A fleshy foot is also present. The nervous system consists of three pairs of ganglia connected by nerves. Eyes are present in many forms and in the higher cephalopods they closely resemble the eyes of Vertebrates. In all but the Pelecypoda the mouth is provided with a lingual ribbon, which is a sort of rasp in the mouth by which in many cases thick shells may be bored entirely through.

Questions. How do the senseorgans of mollusks. which forage for food compare with those of sedentary mollusks?

What protective devices do you observe among mollusks ?

How can one compel an oyster to

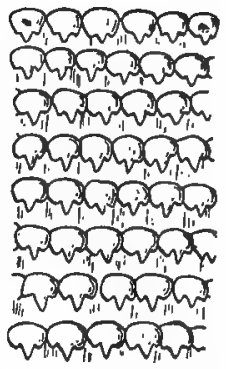

Fig. I31.-Part of a Lingual Rib. bon (magnified). produce a pearl?

Topics for Reports. Tyrian Dyes. Eye-stones. The Octopus and Squid. The Chambered Nautilus. 
The Argonaut. Some Fabulous Monsters of the Sea. Oyster Farming. Pearl Fisheries. Famous Pearls. The Ship-worm. Wampum and Suckanhock. The Scallop.

\section{VOCABULARY.}

Ad duc'tor (Lat. $a d$, to, and duco, (r.d), a word applied to the muscles which hold together the sluells of bivalves.

An'o don (Gr. a, priv., and-odous, a tonth), a genus of fresh-water mussels having no hinge-teeth.

Bi'valve (Lat. $b i$, two, and valva, a leaf of a door), having two shells which open and shut.

Bran'chi a (Gr. branchia, gills, pl. of branchion, a fin), gills.

Bys'sus (Gr. byssos, a kind of flax), a bunch of tough threads by means of which some bivalves attich themselves to rocks.

Car niv'o rous (Lat. caro, flesh, and voro, to devour), flesh-eating.

Col umel'la (Lat, dim. of columen, a column), the upright pillar in the axis of a univalve shell.

Dex'tral (Lat. dexter, right), right-handed,

E pi der'mis $1 \mathrm{Gr}$. epi, upon, and derma, skin), the outer skin of an animal.

Her biv'o rous (Lat. herba, grass, and voro, to devour), vegetableeating.

Hinge Lig'a ment (Lat. ligo, to bind), an elastic substance forcing open bivalve shells when the muscles relax.

Lin'gual Rib'bon (Lat. lingua, tonguel, a rasp-like organ used in boring holes through shells.

Man'tle (Lat. manus, hand, and tela, a web), the soft outer covering of the body of a mullusk, commonly just under the shell.

Na'cre, mother of puarl.

E soph'a gus (Gr. oiso, will bear and phagein, to eat), the tube leading from the mouth to the stomach.

0 per'cu lum (Lat. operculum, a lid), the lid closing the aperture of a snail's shell.

Pal'li al Line (Lat. pallium, a mantle), the mark on the inside of a mollusk-shell made by the mantle.

Se'tæ (Lat. pl. of seta, a bristle), bristles.

Sin'is tral (Lat. sinister, left), lefthanded.

Si'phon (Gr. siphon, a siphon), a tube for passing water through the gill-cavity of a mollusk.

Su'pra $\propto$ soph a ge'al (Lat. supra, above, and a'sophagzes), an adjective applied to the ganglion above the throat.

Um bil'i cus (Lat. umbiliczes, navel), an opening near the cen. tre of the base of some spiral shells.

Um'bo (Lat. umbo, the boss of a shield), a prominence near the hinge of a bivalve shell.

Un'io (Lat. unus, one), a genus of fresh-water mussels.

Whorl, one turn of the spire of $a$ univalve shell. 


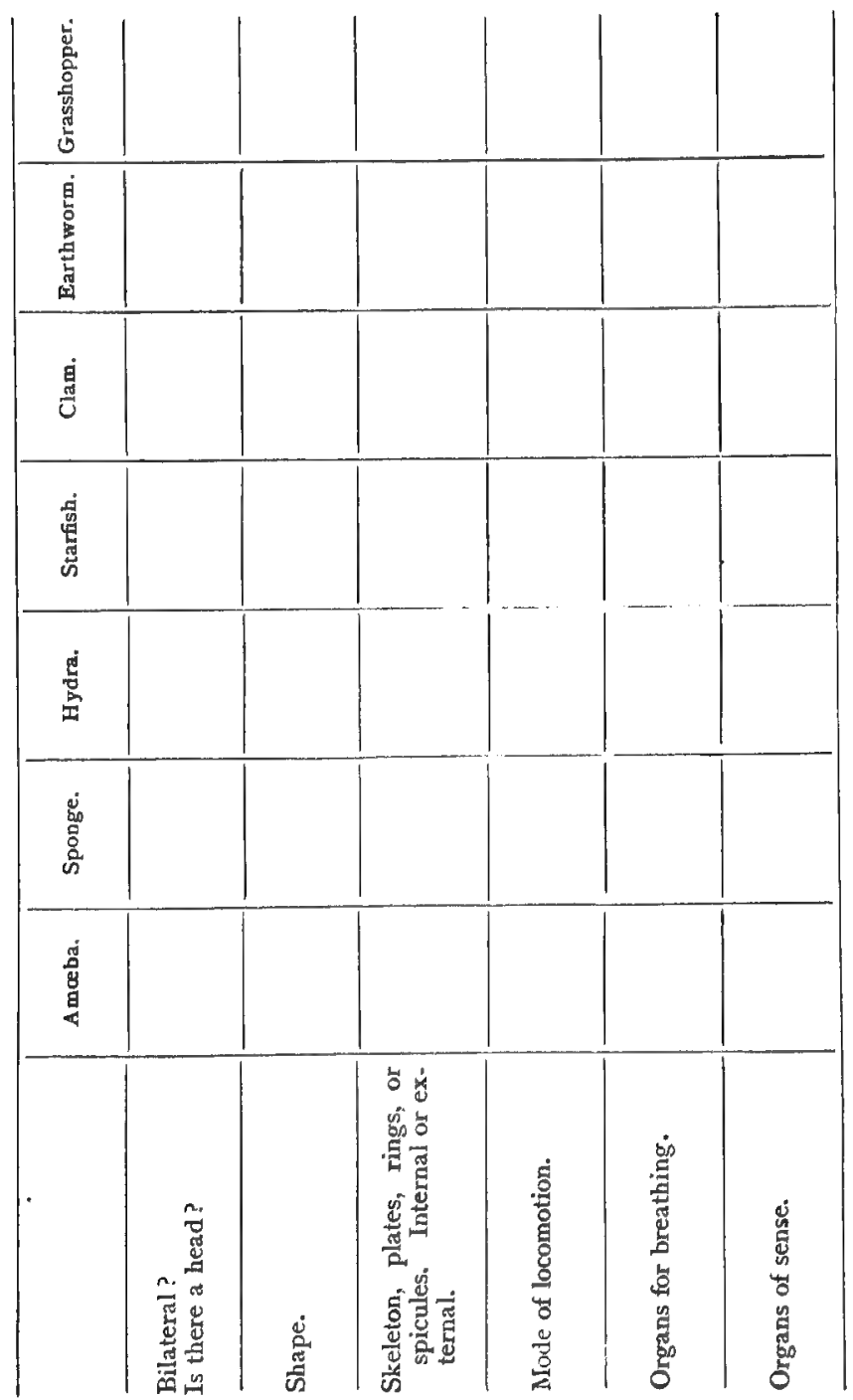




\section{CHAPTER XVI.}

THE STRUCTURE AND ACTIVITIES OF A FISH.

GOLDFISH or other small fish from streams or ponds are easily kept in aquaria. With a few living fish placed where pupils can observe them, and a smelt or perch from the market as an individual specimen for study on each bench, the following questions may be answered:

Shape and Covering: Is the fish bilateral? Estimate length, thickness, and depth.

What is the shape of the body?

Do you find a head? a neck?

Do you find scales? Do they cover the entire animal?

Are the scales joined edge to edge (tesselated) or do they overlap (imbricated)?

Remove some of the skin. What is the appearance of the muscle below?

Notice the line extending along the side of the fish from head to tail (lateral line). Do the scales covering this line differ from those found elsewhere on the body?

The Fins. How many fins do you find? How many are dorsal? How many ventral? How many are paired?

Which fins correspond to the limbs on our own bodies?

The paired fins nearest the head of the perch are called the pectoral fins, those somewhat farther back nearer the anal opening are called the pelvic fins. The large fin along the back is the dorsal fin. The unpaired I69 
fin along the merlian ventrat line is the aner ore armberl fin. The fin at the coll of the tail is the ermertel fin.

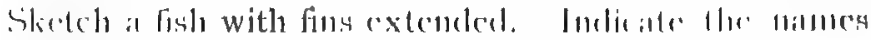
of the fins.

()) what use are the bones in the lins (fintiays)?

l)es the fish swim by uwing its fins, or its lail, al |witl?

The Head. What organs of scuse do youl fincl? The cars atre internal.

Are the cycs movable? 1) Hory have lides? How dres the eye of the fish resemble the cye of man? w the grasshopper? How does it differ from these?

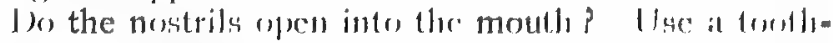
pick for a probe. Are the nesitrils of ulse in lirallhin!? Of what use are they?

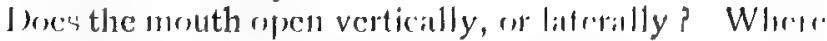
are the tecth situated? What is their Hhilfe? Whill about the shape atrd presition of the tomg!lle?

Gills and Heart. What movennents dor's the lish make while breathing ?

Ratise the grill-cover of the sifecimen an ther hermh. low many frilly do you find? Jow many bill-cledta is speaces betwern the grills ?

The bony sulpowts of the gills are callerl lerant/liml

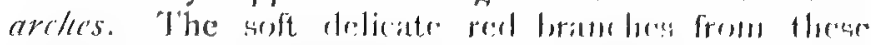

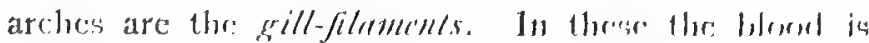
purified. What is the color of the hlowel of a fishl? Can you see the branchial arehes by lonkin!! into Hor mouth of a fish ?

Remove the skin and muscular walles from thate pert-

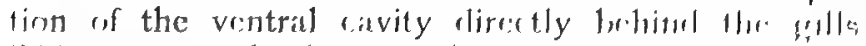

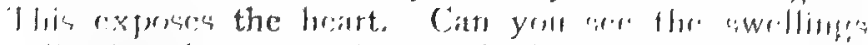

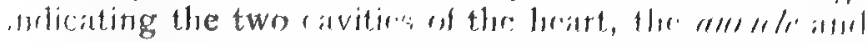

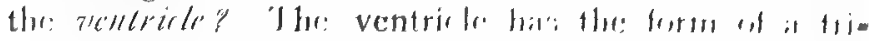

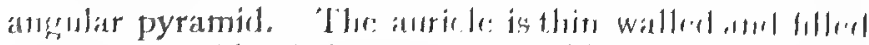

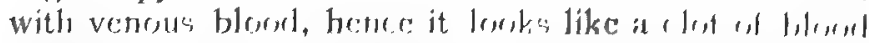

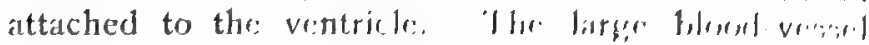
from the heart to the gills is the ventrial iortit. I1: 
enlargement near the heart is called the arterial bulb. The birrod-vessels bringing blood tr, the heart are called veins. Lo you find the ventral aorta, the arterial bulb. and a large vein? Make a sketch to show their presition.

Sketch a single gill from a cod, or other large fish. Indicate the parts observed. Trace the course of the bloodvessels in an injected specimen.

\section{Internal Structure.} With a sharp knife make a cross-section of the body of a fish a little in front of the anal opening. Sketch the appearance of the section, showing the lrocation of the vertebral column or back-bone, the spinal nerve within the neural cavity, the visceral cavity, and the muscles surrounding all. Do you find any large blood-vessels?

Place the fish on its side in the bottom of a pan containing water enough to cover it. With scissors re-

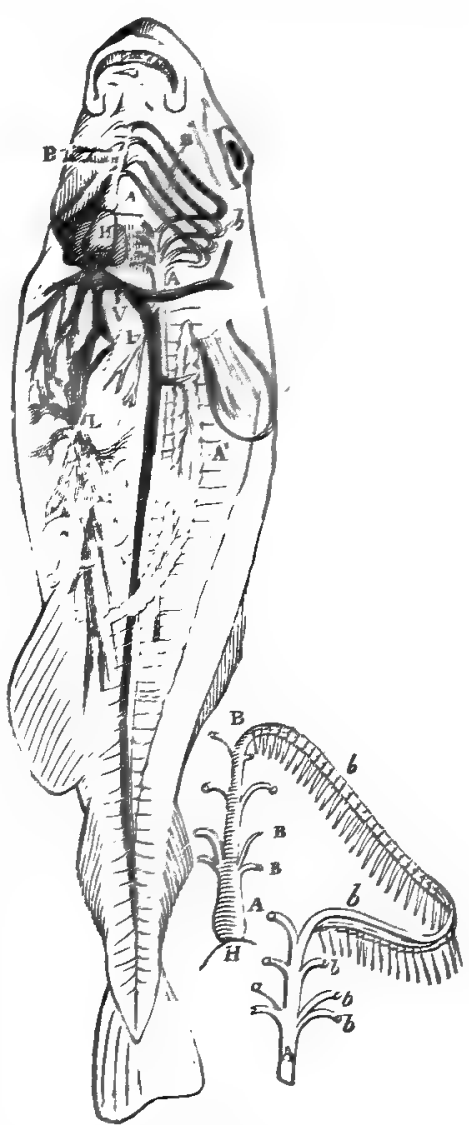

FIG. 132.-The Circulation of Blorod in a Fish. $A$, anortic bulb; $H$. heart; $B$, arteries supplying gills; $V$, veins; $b$. veins conveying atrated blood from the gills to the dorsal aurta; $L$, vessels of liver; $A^{\prime}$, kidney. move the portion covering one side of the digestive 
cavity, being careful not to disturb the organs within. Do you find the body-cavity?

Pass a probe down the mouth until you are able to make out the stomach, the œsophagus, extending from the mouth to the stomach, and the intestine, extending from the stomach to the anal opening. This is the alimentary canal. Is the intestine coiled or straight? Sketch this alimentary canal.

Do you find a membrane holding the stomach and intestine in place? This is the mesentery. Do you see blood-vessels in the mesentery?

In the front of the body-cavity do you see the large,

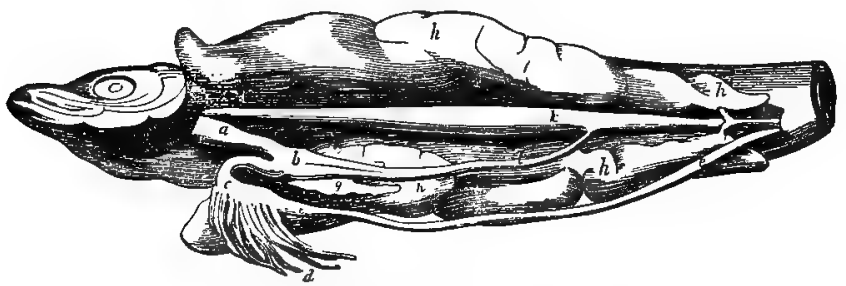

Fig. 133.-Internal Organs of Fish. $a$, osophagus; bcd, stomach; $l$, duct of swimming-bladder; $k$, swimming-bladder; $h$, ovary.

brownish liver? Can you find a gall-bladder, green or yellow in color, attached to the liver?

In the body-cavity can you see the reproductive organs? Usually these are smooth and whitish in the male and yellow and granular in the female.

Directly under the back-bone do you find the airbladder? This organ is homologous with the lungs of higher vertebrates. Do you also find a large bloodvessel above the air-bladder?

Brain and Nerves. Use the head of a large fish obtained from the market. With great care remove the upper part of the skull. Commonly it is better to use preparations previously dissected by the teacher. These may be kept in formalin, or alcohol. The 
largest pair of globular masses are the optic lobes. In front of these we find the cerebral lobes, corresponding to the cerebrum or front brain in man. Behind the optic lobes the cerebellum is situated. Sketch the brain showing all these parts, showing also the olfactory nerves extending to the nostrils, the optic nerves leading to the eyes, the auditory nerves leading to the ear-sac with its "ear-stone," and the spinal nerve extending along the back.

The Bones of a Fish. Skeletons or parts of skeletons can be easily prepared for laboratory use by soaking in hot water. Heads and backbones of large fish can be obtained without cost at the markets in most places.

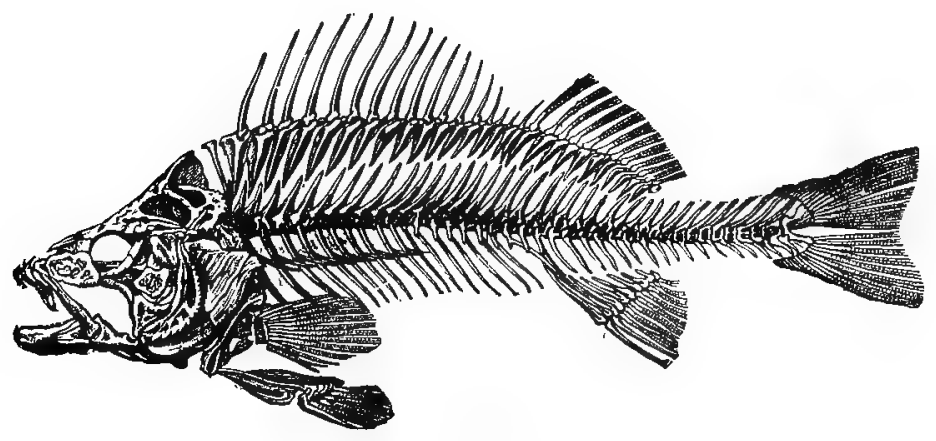

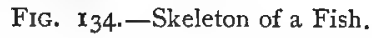

With the skeleton of a fish notice the visceral cavity and the neural cavity. What is the relation of these cavities?

Notice the brain-cavity. Where was the brain connected with the spinal cord?

Do you find openings for nerves extending to ears, eyes, and nostrils?

Do you see how the skull is joined to the vertebral column? 
How is the lower jaw suspended from the skull ?

Separate the back-bone, or vertebral column, into parts (vertebræ). Are the vertebræ near the tail like those near the head? Study particularly one of the vertebræ near the tail. The main part of a vertebra is the centrum. Is the centrum entirely solid? What is its shape in a longitudinal section after removing all soft parts? Sketch front and side view of a vertebra, and a longitudinal section.

Do you find the cavity for the spinal cord? Call this cavity the neural cavity, and the processes attached to the centrum and enclosing the neural cavity, the neural arch, and the spine above it the neural spine. Is this spine dorsal or ventral? Does it point towards the anterior or the posterior part of the body?

Do you find the cavity for the passage of the large blood-vessel ? Call this the hæmal arch, and the spine attached to it the hæmal spine. This arch protects the dorsal aorta. Are there any ribs present?

Using one of the vertebræ above the visceral cavity, find how it differs from a vertebra near the tail.

Summary of Drawings. (a) Side view of fish with fins extended.

(b) Side view of head of a fish showing as many parts as possible.

(c) Gill of a fish showing parts. Heart of fish with arteries and veins.

(d) Cross-section of the body of a fish a little in front of the anal opening. Sketch of alimentary canal.

(e) Brain of fish with nerves.

$(f)$ End view of a vertebra from near the tail.

$(g)$ End view of a vertebra above the visceral cavity.

(h) Longitudinal section of a vertebra.

Vertebrates. The study of a fish introduces us to the class Vertebrata of the sub-kingdom Chordata. The possession of a back-bone made up of vertebræ gives this class its name. This back-bone furnishes a 
flexible axis for the body, and separates the neural from the visceral cavities.

In the young of all vertebrates a rod of cartilage called the notochord runs through the body between the two cavities just mentioned. In some of the lower vertebrates this rod persists throughout life, but in nearly all cases it disappears with the hardening of the centra of the vertebræ. The soft substance extending through the centra of the vertebra of the fish probably represents in that animal the remnant of a notochord. In all adult vertebrates higher than fishes there is left no trace of this structure.

The neural cavity, as its name implies, contains the main nerve of the body, the spinal cord. This cord is enlarged at its anterior end in almost all vertebrates, forming a brain. In all higher vertebrates and in by far the greater part of those lower in organization, this brain is enclosed in a bony box called the skull. Paired organs of sense are connected with the brain. The visceral cavity contains the organs of digestion, the heart, and organs of reproduction. In higher vertebrates it also contains the lungs.

In the great majority of vertebrates there are two pairs of limbs. These are, in the higher vertebrates, usually attached to the main axis of the body by connecting bones called respectively the pectoral girdle and the pelvic girdle. Even in vertebrates which have no arms or legs rudiments of these girdles may sometimes be found.

Fishes. The fishes (Pisces) include animals which live in water and breathe by gills. The body is usually covered with scales, and the form is adapted for locomotion through the water. The paired fins are chiefly used for balancing the body, and the caudal fin is the principal organ of locomotion. Although nasal sacs and nostrils are present, they do not connect with the mouth or throat. There are no external ears. In most fishes an air-bladder is present, often connecting 
with the gullet. This bladder serves to vary the specific gravity of the fish in the water. Sometimes it is used in producing a noise. It is homologous with the lungs of higher vertebrates.

The heart in fishes consists of one ventricle and one auricle. Impure blood, collected by the veins, gathers in the auricle and passes to the ventricle, whence it is forced through the gills where the ordinary interchange of gases takes place. The blood is then distributed to all parts of the body by arteries. See Fig. I 32.

Questions. What do you mean by saying that a fish is cold-blooded?

How much can a fish see?

How much can it hear?

What is meant by saying that a fish's ears are probably organs of equilibrium?

Where are organs of equilibrium situated in some other animals?

How does the tail of a shark differ from that of a salmon?

How do the skeletons of the two animals differ?

Topics for Reports. The Nests of the Stickleback. The Migrations of Salmon. Bream. Trout. Sharks. Electric Eels. The Sea-serpent. Flying Fish.

\section{VOCABULARY.}

A or'ta (Gr. aeiro, to raise), the large artery of the body.

Ar'te ry (Gr. arteria, windpipe), a tube carrying blood away from the heart.

Cau'dal (Lat. cauda, tail), pertaining to a tail.

Cen'trum (Lat. centrum, a centre), the body of a vertebra.

Cer e bel'lum ilat. dim. of cerebrum), the hind brain. It controls combined muscular action.

Cer'e brum (Lat. cerebrum, brain), the front brain, the seat of the reasoning faculties.
Chor da'ta (Gr. chordë, a chord). The sub-kingdom including the back-boned animals.

Hæ'mal (Gr. haima, blood), pertaining to the blood. Sometimes used with the same meaning as visceral.

Het er o cer'cal (Gr. heteros, different, and kerkos, tail), applied to the tails of fishes having unequal lobes.

Homocer'cal (Gr. homos, same, and kerkos), a word applied to the tails of fishes having equal lobes. 
Im'bri ca ted (Lat. imbrex, guttertile), overlapping.

Max'il la ry (Lat. macero, to soften), pertaining to the jaw; commonly to the upper jaw.

Mes'en te ry (Gr. mesos, middle, and enteron, intestine), in vertebrates the membrane holding the intestines in place.

Neu'ral (Gr. neuron, a nerve), pertaining to the nerves. In vertebrates it is applied to the dorsal cavity of the body.

No to chord (Gr. notos, back, and chorde, a cord), a rod of cartilage from which the vertebral column develops in vertebrates.

E soph'a gus (Gr. oisō, will carry, and phagein, to eat), the tube connecting the throat with the stomach.

O per'cu lum (Lat. operculum, a lid), the gill-cover in fishes.

Pec'to ral (Lat. pectus, breast), pertaining to the breast.

Tes'sel la ted (Lat. tessellatus, checkered), formed in squares like mosaic.

Ver'te bra (Lat. verto, to turn), one of the sections of the vertebral column.

Vis'ce ral (Lat. viscera, internal organs of the body, pertaining to the internal organs; applied to the ventral cavity in vertebrates. 


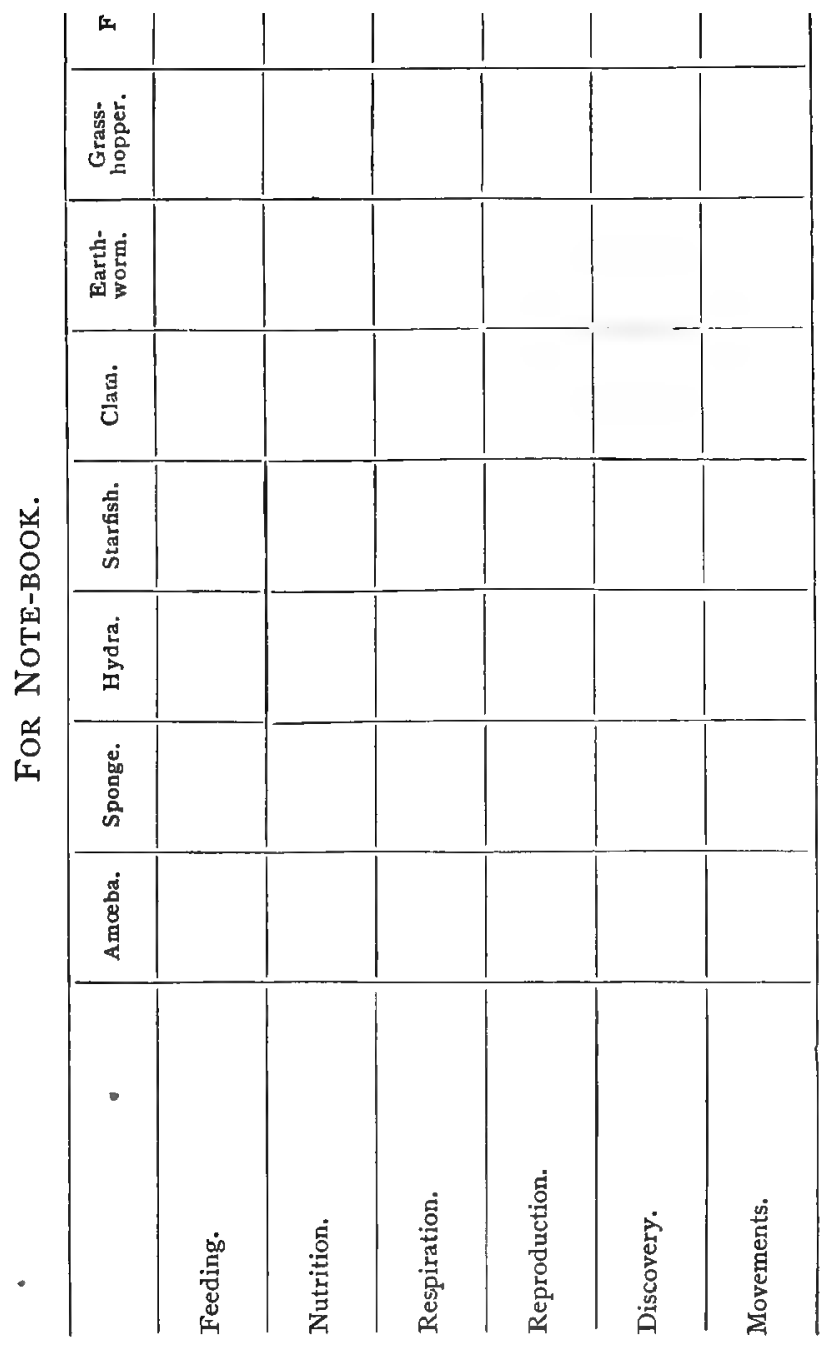




\section{CHAPTER XVII.}

\section{TADPOLES AND FROGS.}

IN the study of the frog, aquaria are indispensable. The expense, however, need not be large. In one aquarium tadpoles should be placed together with a few aquatic plants. The minute green plants which grow on the sides of the aquarium will furnish food enough. The adult frogs can be kept in a box with glass sides with only a small amount of water in the bottom and a netting to cover the top. In warm weather frogs feed on insects; in winter they go without food.

The Tadpole. Is it bilateral?

Is the skin naked or scaly? Do you see a lateral line?

In what ways does it resemble a fish?

How does the tail of a tadpole differ from the tail of a fish?

In any of the tadpoles can you see the beginnings of limbs? Which limbs appear first?

In a young tadpole how do the gills appear?

Can you see the gills in an older tadpole? Do tadpoles come to the surface of the water to breathe?

Can you find in a specimen which has been hardened in alcohol a gill-cavity? Can you find an opening into this cavity?

Are the jaws hard or soft? Watch the tadpoles feeding on the sides of the aquarium, or jar.

How does the size of the mouth compare with that in the adult? 
In a specimen which has been hardened in alcohol do you find vertebræ? Do you find a notochord? Do you find muscles like those in the fish? Notice the spirally coiled intestine.

Hold the tail of a living tadpole under a compound microscope and observe the movement of the blood. Notice the corpuscles.

Summary of Drawings. (a) Side view of tadpole.

(b) Dorsal view of a young tadpole to show gills.

(c) Sketch to show blood-vessels as seen under the microscope.

The Frog Alive. How does the frog resemble the fish? the tadpole?

Do you find scales, hair, claws, or nails?

Do you find tail or fins? How about legs ?

What is the frog's mode of locomotion on land? in water?

How many divisions have the hind limbs? the fore limbs? How do they compare with the limbs of the human body? Do the joints move in the same way as ours? Do you find arm, forearm, and wrist?

How many fingers? How many toes? Are fingers or toes webbed? Do you find a thumb?

How does the frog take its food? How does the tongue act?

What movements are made in breathing? Are there any gills? How long can a frog live under water?

Does the frog have the same senses and the same organs of sense as man?

Do you find ears? eyelids? Do you find a membrane covering the eye (nictitating membrane)?

Frog Hardened in Alcohol. Look in the mouth. Do you find any teeth? How many? Where are they?

What is the shape of the tongue?

Do the nostrils connect with the mouth?

Does the ear-cavity connect with the mouth? 
(Eustachian tube.) Cut open the membrane covering the ear and use a probe.

Using a prepared specimen showing the internal organs, do you find the peritoneum? the mesentery? the stomach? the intestine ? the liver? the heart?

Do you find the lungs?

Is there a diaphragm separating the heart and lungs from the stomach, liver, and intestine?

Dorsal to the viscera in a freshly prepared specimen look for nerves branching out from the spinal cord. Do you find nerve-masses (ganglia) on these nerves on each side of the spinal column? Are these ganglia connected by a nerve running lengthwise? Call this the sympathetic system of nerves.

In a prepared specimen notice the brain and spinal cord. Sketch the brain in outline. How does this sketch compare with the sketch you have made of the brain of the fish?

In what ways does a frog resemble a fish ? How does the frog differ from the fish?

Summary of Drawings. (a) Outline of organs seen in the visceral cavity.

(b) Sketch of ganglia of sympathetic system with connecting nerves.

(c) Outline sketch of brain of frog.

Activities. Both the structure and the activities of the frog interest us because they are so much like those of man himself. The frog has been much studied because of the remarkable changes in structure and habits which the animal undergoes after leaving the egg.

Taking Food. The frog lives on insects, worms, and other small animals. As a rule frogs eat only during the summer months, remaining torpid without food in winter. The tongue of the frog is peculiarly adapted for catching insects. It is fastened to the lower jaw by its front end, and turns a somersault when shot out at a fly. The hinder end is covered with a sticky 
saliva which holds the fly a prisoner until the jaws close over him. The ease and quickness with which

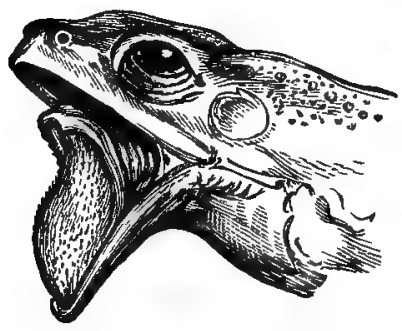

FIG. 135.-Tongue of a Frog. an insect disappears are always a surprise to the observer.

When feeding on large animals the frog seizes his prey with jaws and front legs, and hurriedly crowding his luckless victim into his mouth, swallows him alive. Teeth are present on the upper jaw and on the palate or roof of the mouth.

Taking 0xygen. When the young frog emerges from the egg it takes air from the water by means of external gills. Into these the blood is pumped directly from the heart, as in fishes. Here the oxygen passes into the blood for purification, and thence is conveyed to all parts of the body.

In a few days these external gills disappear, and other gills grow under the opercular membrane. This

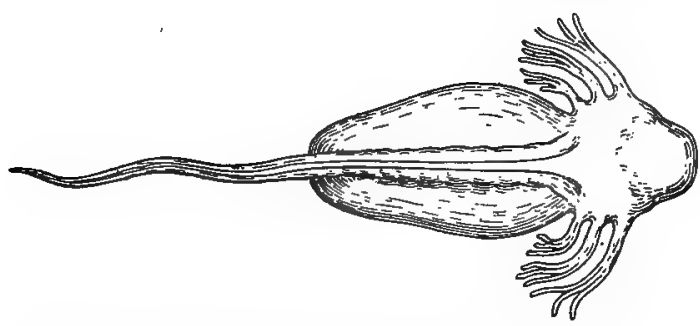

FIG. 136.-A Young Tadpole Showing External Gills.

membrane is joined to the body-wall except on the left side, where an opening for the passage of water remains.

The young frog now breathes like a fish. The 
heart, too, like that of a fish, has only two chambers, an auricle and a ventricle.

After a time lungs develop, and the tadpole, while still using his gills to some extent, finds it necessary to come to the surface of the water occasionally for air. Finally the gills disappear and the frog breathes only

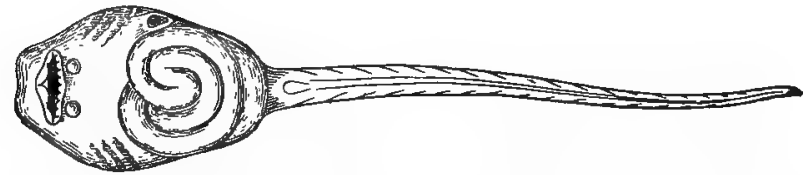

Fig. 137.-Under Side of Tadpole Showing Coiled Intestine and Internal Gills.

by lungs. While these changes are going on, the heart develops another auricle on the left side for the reception of the purified blood from the lungs. The right auricle receives the impure blood returning from the circuit of the body.

Not only does the frog, at different times, breathe in the three ways just mentioned, but at all times it

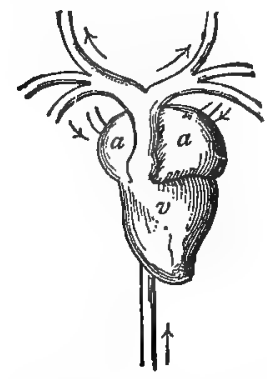

FIG. I38. - Heart of Adult Frog. «, auricles ; $v$, ventricle.

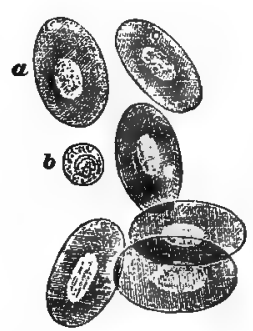

Fig. I39. - Blood-cells of a Frog. $a$, red corpuscle; $b$, colorless corpuscle.

breathes by the entire surface of the body, the skin being especially rich in blood-vessels. 
The adult frog pumps the air into the lungs by the movements of the muscles of the throat and lower part of the mouth-cavity. When the mouth-cavity enlarges, air rushes in through the nostrils. When the cavity contracts, valves close the openings to the nostrils and the air is forced down into the lungs. The frog has

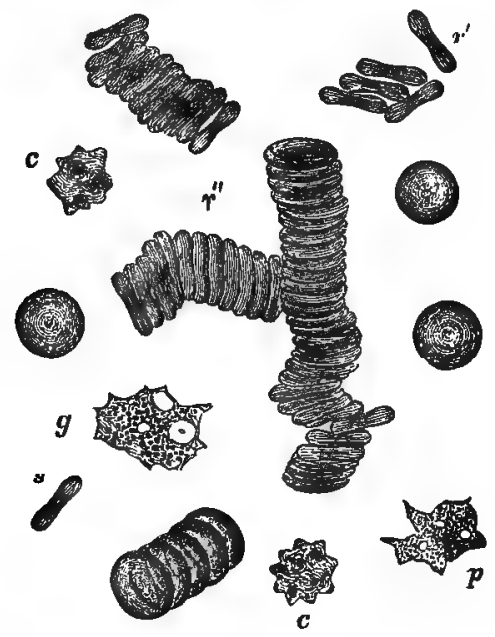

Fig. 140.-Blood-corpuscles of Man. $s, r^{\prime}, r^{\prime}$, red corpuscles; $\not p$ and $g$, white corpuscles; $c$, crystals.

neither ribs nor diaphragm-organs of great importance in our own breathing.

The oxygen, once taken by the blood, is carried by the red corpuscles, or blood-cells, to all parts of the body, where in the capillaries it is given up to burn, or oxidize, tissues and food substances in order to produce heat and energy.

Nutrition. Food passes from the mouth to the stomach, where it is acted on by fluids like those in our own bodies. It then passes to the intestines, where the bile secreted by the large liver and the pancreatic 
juice from the pancreas are poured upon it. Here further changes take place and the digested food is absorbed and taken to the blood-vessels. The undigested portions of the food pass along the intestine to the cloaca, which is the common receptacle for use-

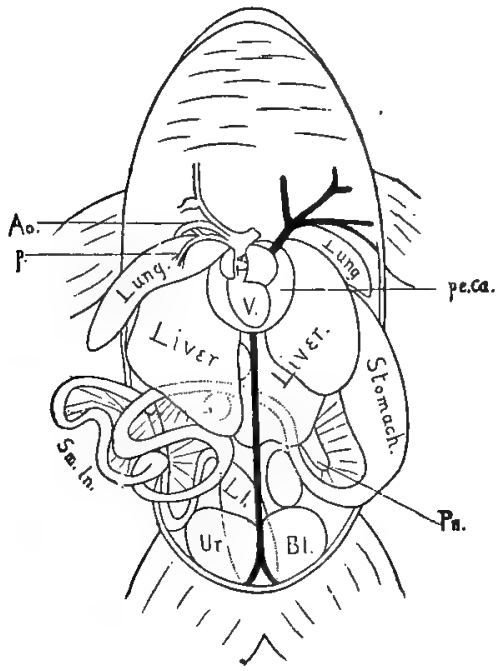

FIG. I4I.-Viscera of Frog. Sm.In., small intestine; L.I., large intes. tine; Ur. Bl., bladder; pe.ca., pericardial cavity; $V$, ventricle; $T . A$, large artery; $A o$, aorta; $p$, pulmonary artery; $P n$, pancreas.

less substances from the food-tube, and the kidneys and eggs or sperm-cells from the reproductive organs. Thence the useless matter and the reproductive cells pass from the body.

When the tadpole first comes from the egg, the foodtube quickly grows into the long coiled tube shown in Fig. 137 and this in turn gives place to the tube as we have seen it in the adult frog.

It is interesting to note that the lungs, liver, and pancreas are outgrowths from the side of the food-tube, 
produced by a pushing out of the walls of the tube itself (Fig. I 43).

Excretion. Carbon dioxide and water are taken by the blood-corpuscles to the breathing organs and to the skin, where they are thrown out of the body. Urea and

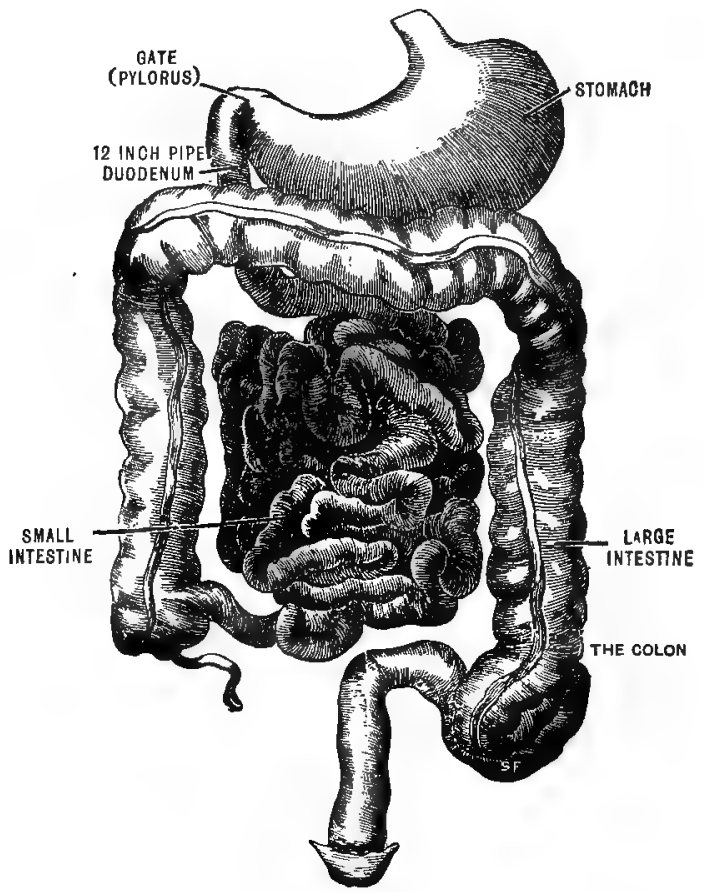

FIG. 142.-Digestive Organs of Man.

water are taken from the blood by the kidneys and passed along to the urinary bladder and thence out of the body.

Reproduction and Metamorphosis. The female frog deposits her eggs in the water in spring in large jelly-like masses. As soon as hatched the young tad- 
poles cling in clusters to plants, or other objects; life being sustained by the food-yolk within the body. After a few days, a mouth with horny jaws develops and the animals begin to feed.

The tadpole now eats plants, being especially fond of the green conferva so common on the sides of aquaria.

Growth is now rapid, and in a few months the legs appear and the tail is absorbed.

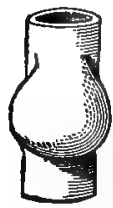

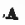
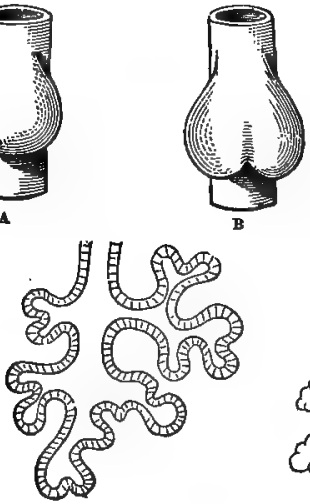

$\mathbf{D}$

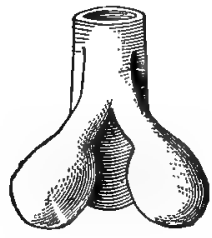

c

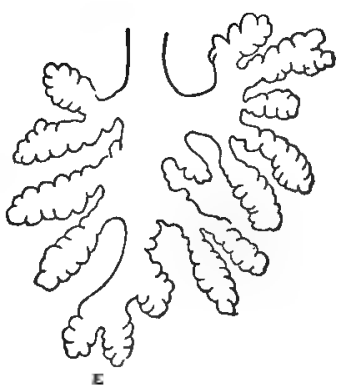

FIG. I43--Growth of Frog's Lung from Primitive Food-tube.

Movements. The most important organs of motion are the muscles. A muscle causes movement by shortening itself, and thus bringing nearer together its two ends with whatever is attached to them. In general, muscles are attached to bones. How muscle and bone together produce movement may be well understood by studying Fig. I 48 in connection with the movements of the human arm. 
A muscle shortens because the cells of protoplasm of which it is composed all have the power of contrac-
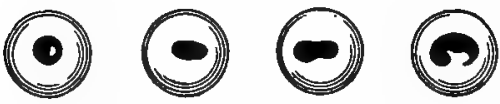

Fig. I44.-Growth of Frog's Egg. tility. The cells all contract in one direction, making the whole muscle shorter and thicker. These contractions

are under the control of the nerves.

A number of muscle-cells make one of the fibrilla. Several of these fibrilla wrapped in a sheath form a fibre. The fibres are wrapped in bundles, and these bundles are covered by a thin layer of tough connective tissue. The sheaths or coverings of muscles, bundles, and fibres unite to form tendons by which the muscles are attached to the bones (Figs. I 49 and I 50).

Muscles under the control of the will, like those in the leg of a frog or of a man, show peculiar cross-markings. Muscles not under the control of the will, like those of the intestine or stomach, are commonly unstriped.

The bony skeleton of the frog, on which the muscles act to cause the movements of the body, has an axis of nine movable bones, the vertebræ. Behind these a long bone, the urostyle, reaches to the hips, and in front is attached the head with its broad skull and large jaws. On the base of the skull are two rounded prominences called condyles, which fit into corresponding de-

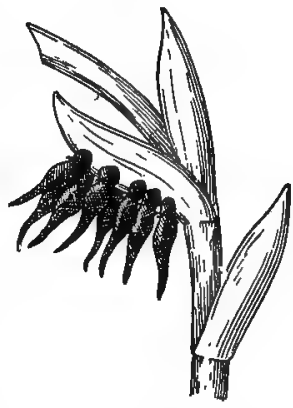

FIG. 145.-Very Young Tadpoles. pressions on the atlas-bone, the first bone of the vertebral axis (Fig. I $5 \mathrm{I}$ ).

The fore limbs are attached to the axial skeleton by muscles and ligaments. A shoulder, or pectoral girdle, consisting of several bones is present. The hinder 
limbs are attached to the axial skeleton through the pelvic girdle. The bones of the arm consist of the humerus, or forearm, the radio-ulna, corresponding to

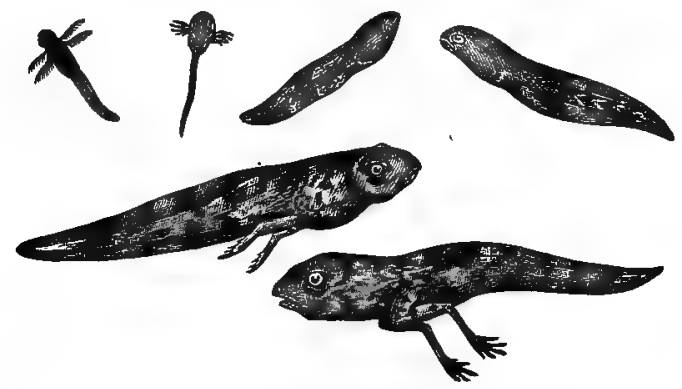

Fig. 146. - Various Stages of Tadpole.

the two bones, the radius and ulna in man, the carpal or wrist-bones, the metacarpal or hand-bones, and the fingers or phalanges. In the leg are the femur or thigh-bone, the shin-bone corresponding to the tibia
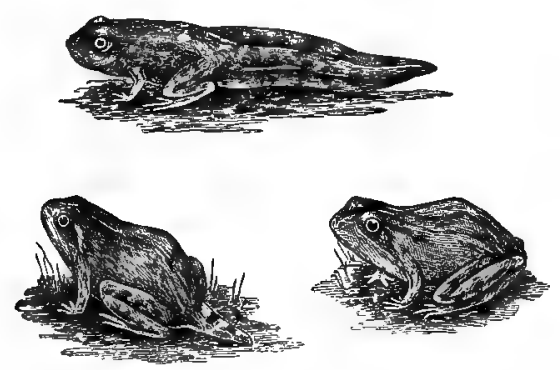

FIG. 147--Young Frogs.

and fibula in man, the tarsal bones, two of which are much longer than the others, the metatarsal or anklebones and the phalanges (Fig. I 52).

Controlling the organs of motion and extending into 
every muscle for that purpose is the nervous system. This consists of a brain connected with the spinal cord, and a series of ganglia with nerve connections in the visceral cavity. From these centres nerves run to all parts of the body. The division between brain and spinal cord is not so sharp as in man. The brain itself has the same parts as the brain of man, but these parts do not have the same shape or relative size (Figs. I 53 and I 54).

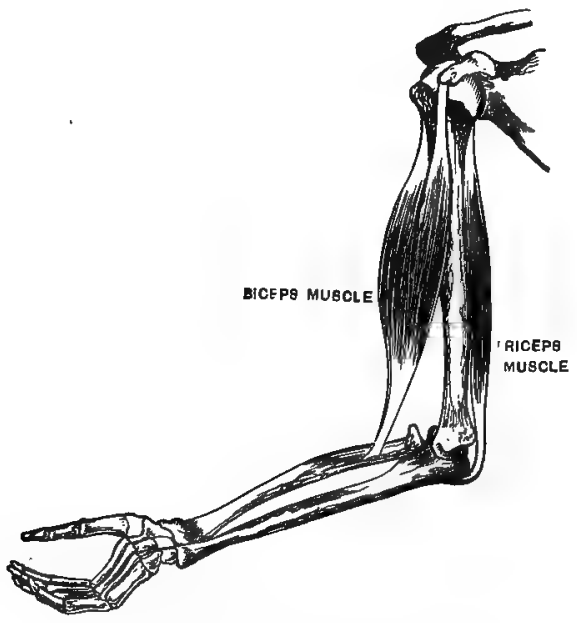

FIG. I48.-The Use of a Muscle.

Notice how large the olfactory and optic lobes appear in the frog. In man they are small and do not show in the figure. In man, too, the cerebrum or forebrain has grown so large that it occupies almost the whole of the brain-cavity. These facts of structure would seem to indicate that sight and smell are of more importance to the frog than memory or reason.

Discovery. It is the duty of the nervous system to keep in touch with the outer world, in order that the movements made may be useful to the animal. 
Sight. The optic lobes just mentioned are connected with a pair of eyes very much like our own. Each eye is really a camera obscura with its lens and darkened walls. The image of an external object is thrown on the retina, which corresponds to the ground glass of a camera and is composed of nervous tissue forming the end of the optic nerve. The frog sees well,

\section{B}

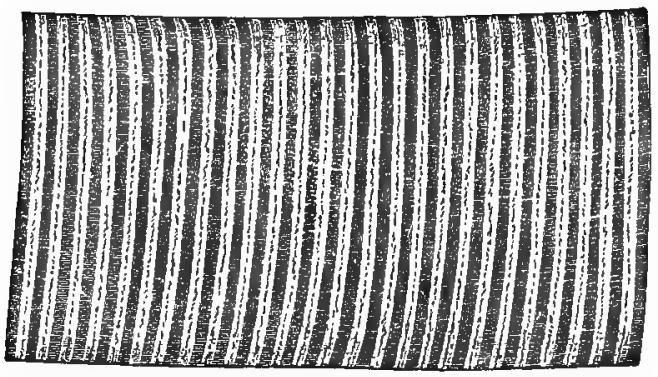

$A$

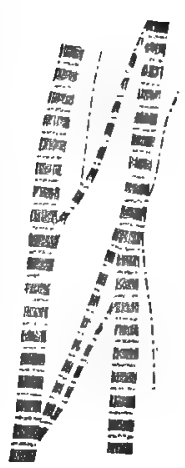

FIG. 149.-Striped Muscle-fibres. $A$, a fibre much magnified; $B$, a fibre breaking up into fibrillæ.

as is evidenced by the precision with which he strikes a fly with his tongue.

Hearing. On either side of the head is a dark circular spot which indicates the position of the ear. This ear is wholly internal. Under the skin is a membrane, or ear-drum, and under that a cavity, the middle ear. This cavity connects with the mouth by the eustachian tube as in man. Back of this cavity is another, the inner ear, containing the nerves which conduct sound vibrations to the brain.

Smell. In the nasal cavities fibres of the olfactory nerve are spread out to receive the sensations of smell. 
Taste. Special organs of taste are found on the tongue and on the membrane lining the mouth.

Touch. The skin is well supplied with nerves, and there are special tactile areas.

Classification. The frog belongs to the division of Vertebrata known as Amphibia or Batrachia. They receive their name Amphibia from the fact that the young live in water breathing by gills, while the adult forms breathe air. As might be expected, there are exceptions to this general rule. The Amphibia are destitute of scales, the skin being perfectly naked, and in most cases provided with peculiar glands. They have no claws. The Amphibia differ from the fishes in having a connection between the mouth and nostrils, and also between mouth and ear. The heart in the adult has three chambers, a ventricle and two auricles. In the larva the heart is two-chambered. All live in fresh water. To this class belong the toads, frogs, and salamanders.

Reptiles. Questions similar to those used concerning the frog may be answered about turtles and snakes. Living turtles and snakes are easy to obtain and fairly easy to keep alive. A large box with glass sides covered with wire netting makes a good vivarium. Sand and gravel and a dish of water should be kept in the bottom of this box. A little moss provides a carpet.

The class Reptilia resembles in many ways the 
Amphibia. The class includes many animals resembling toads and salamanders, besides the well-known turtles, snakes, crocodiles, and alligators. Among Reptiles the body is more or less completely covered

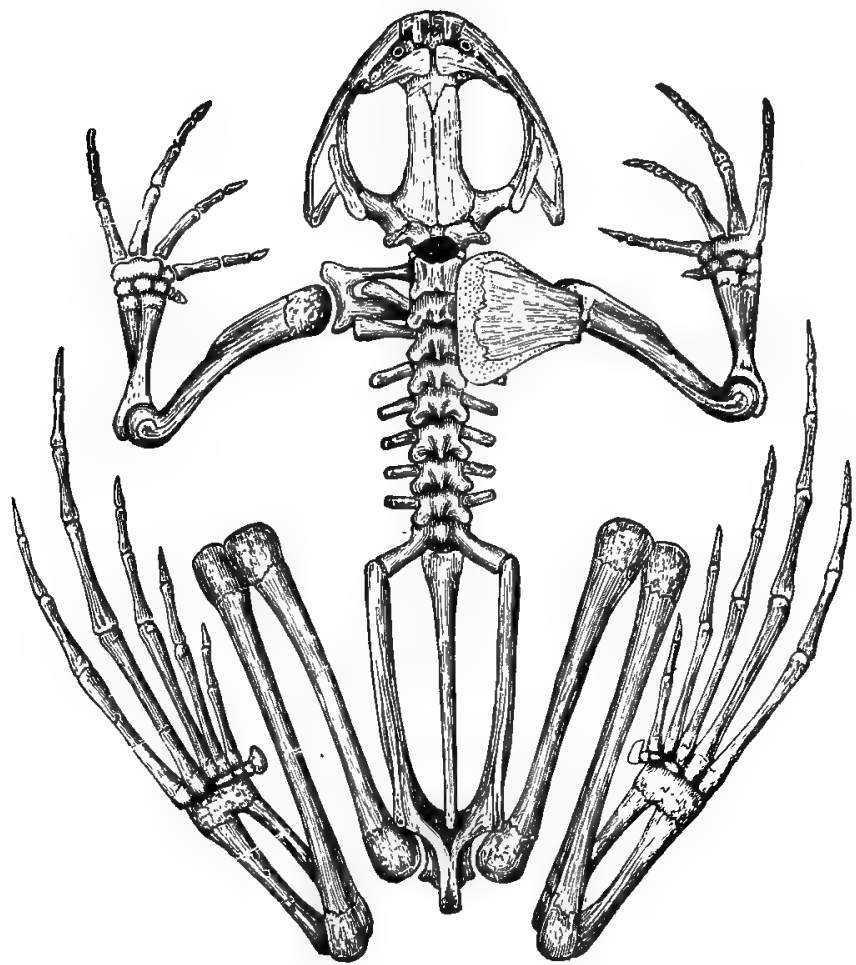

FIG. I5I.-A Frog's Skeleton.

by scales, and when there are any toes these are armed with claws. The heart is three-chambered, as in the case of Amphibians, except in alligators. The young do not breathe by gills as in Amphibia. The eggs are 
commonly large and when deposited for hatching outside of the body are covered with a limy shell. A
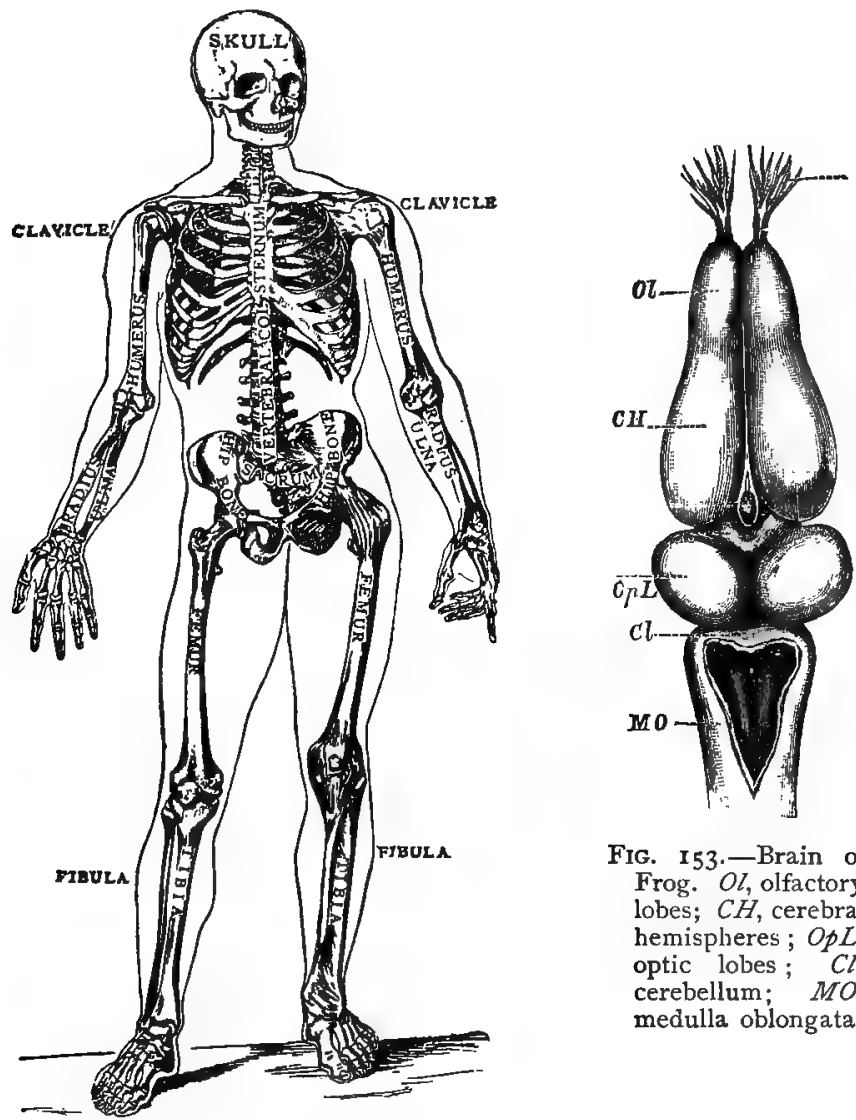

FIG. I53.-Brain of Frog. $O l$, olfactory lobes; $\mathrm{CH}$, cerebral hemispheres ; OpL, optic lobes; $\mathrm{Cl}$, cerebellum; $M O$, medulla oblongata.

FIG, I52,-A Man's Skeleton.

peculiarity of the skull of Reptiles is the presence of the quadrate bone, a characteristic shared also by birds. 


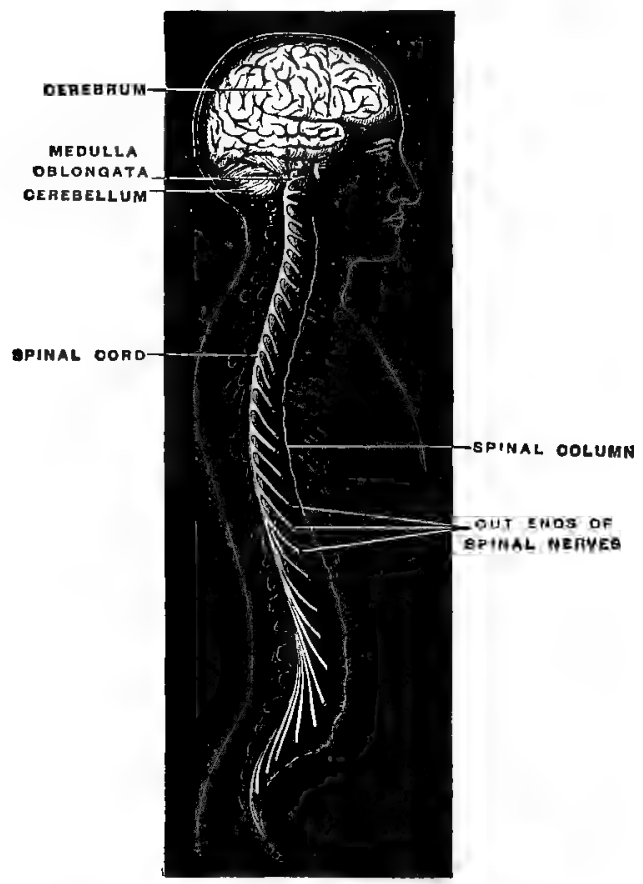

Fig. 154--Brain and Spinal Cord of Man. 
FOR NOTE-BOOK.

\begin{tabular}{|c|c|c|c|c|}
\hline & Fish. & Tadpole. & Frog. & Turtle. \\
\hline $\begin{array}{l}\text { Head and } \\
\text { Neck. }\end{array}$ & & & & \\
\hline Limbs. & & & & \\
\hline Claws. & & & & \\
\hline $\begin{array}{c}\text { Covering of } \\
\text { Body. }\end{array}$ & & & & \\
\hline Teeth. & & & & \\
\hline Skeleton. & & & & \\
\hline $\begin{array}{l}\text { Heart and } \\
\text { Lungs. }\end{array}$ & & & ${ }^{*}$ & \\
\hline $\begin{array}{c}\text { Organs of } \\
\text { Sense. }\end{array}$ & & & & \\
\hline Movements. & & & & \\
\hline
\end{tabular}




\section{CHAPTER XVIII.}

\section{BIRDS.}

IN birds the skin produces feathers instead of scales as in fishes and reptiles. For the study of birds, pigeons or English sparrows are easily obtained. Birds that are sold for food may be bought at the markets and used to illustrate different parts of the work. Living birds of some sort should be kept in the laboratory for a time while bird-study is going on. Of course nothing can take the place of out-of-door work with this class of Vertebrata. In answering the following questions a living bird should be observed, and stuffed specimens of the English sparrow should be in the hands of the pupils.

The Sparrow. Note the shape and color of different parts, method of locomotion, both in walking and flying, how it eats and drinks and cares for its feathers.

Do you find eyelids? Do you find a nictitating membrane? This is a thin membrane at the inner corner of the eye. How does the membrane act?

Does the bird have ears? Where are they?

Does it have teeth? How would you describe the mouth ?

Do you find nostrils? Is the breathing rapid or slow? What do you think about the bird's temperature?

Does the bird use its wings while walking ?

What seems to be the use of the tail ?

Does the bird moult? 
Where does the bird find the oil used in preening its feathers?

How does the size of a bird's egg compare with the size of its body? How does the size of a frog's egg compare with the size of its body?

Are the senses of the bird keen or dull? Does the bird have the same senses as man?

How would you describe the song of the bird you are studying?

The Wing. What is the shape of the wing ?

How many joints has it?

Do you find bones corresponding to those of your own arm, forearm, wrist, palm, and fingers? Use a prepared skeleton of a wing.

How many bones in arm, forearm, wrist, and palm? How many fingers? Is there a thumb? Sketch the skeleton of the wing.

Does the skeleton of a frog show a similar structure of the arm? How does the arm of a turtle compare with the wing of a bird? .

Do you find feathers on the thumb? on the hand? on the forearm? on the arm?

The Leg and Foot. Do you find thigh, shin, ankle, foot, and toes? Where is the heel? Sketch the skeleton of the leg.

How many toes? Do all the toes point in the same direction?

Are there feathers or scales or both on the tarsus?

When scales are present what is their shape?

Are there webs between the toes?

In a fresh specimen can you find the tendon which moves the toes? How do the toes act in perching ?

Feathers. Obtain some large feathers from the wing or tail of a pigeon or a barn-yard fowl. Notice in a single feather the shape as seen in outline. Do you make out the shaft and the vane? Sketch a feather.

Can you separate the parts of the vane into branches of the shaft (barbs)? 
Using a simple microscope, can you find that the barbs themselves bear branches (barbules)? Sketch a magnified barb showing barbules.

What seems to be the use of the barbules?

Do the feathers from different parts of the body seem to have the same parts?

Examine a downy feather and a pin-feather. How do those compare with the other feathers?

What is the appearance of the skin of a fowl from which the feathers have been plucked?

Are the pits from which feathers grow equally distributed over the body?

Summary of Drawings. (a) Sketch of skeleton of a wing, naming humerus, radius, ulna, carpal, and metacarpal bones, and phalanges.

(b) Sketch of a wing covered with feathers.

(c) Side view of foot and leg, naming femur, fibula, tibia, tarsus, metatarsus, and phalanges.

(d) Sketch of whole feather.

(e) Sketch of a barb showing barbules (magnified).
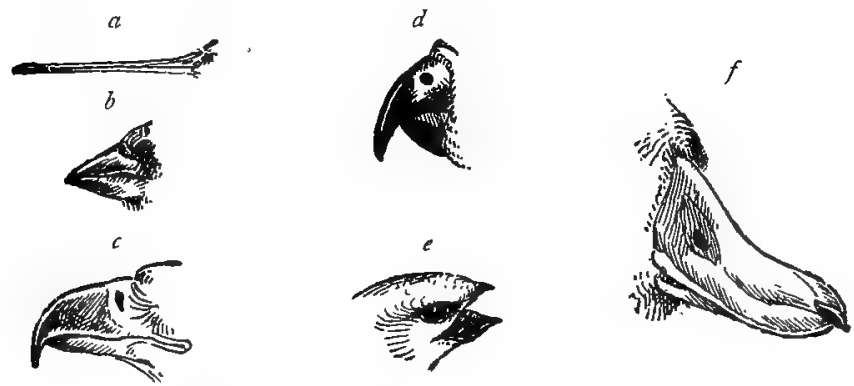

Flज. I55.- $u$, beak of snipe, fitted for probing in soft mud; $b$, beak of sparrow, fitted for cracking seeds; $c$, beak of eagle, fitted for tearing flesh ; $d$, beak of parrot, fitted for cracking nuts ; $P$, beak of swift, ftted for seizing insects while on the wing; $f$, beak of duck, fitted for skimming the water.

The Activities of the Bird. Taking Food. Very noticeable is the difference between the bill of a bird 
and the jaws of a frog or fish. Noticeable, too, is the resemblance between the bill of the bird and that of the turtle. The hard toothless mandibles, however, are well fitted for the purpose of securing the insects and seeds on which most birds feed. Before man invented tweezers, the woodpeckers pried into the bark of trees and pulled out the hidden insects with their long, strong pliers.

These illustrations show some of the forms the beak takes to make it a better tool for procuring the particular kind of food on which the bird lives. In addition to its other uses the beak often serves as a hand.

Birds and Insects. Insect-eating birds devour tons of destructive pests in our orchards and fields. It has been estimated that a single chickadee may destroy more than a hundred thousand canker-worm eggs in

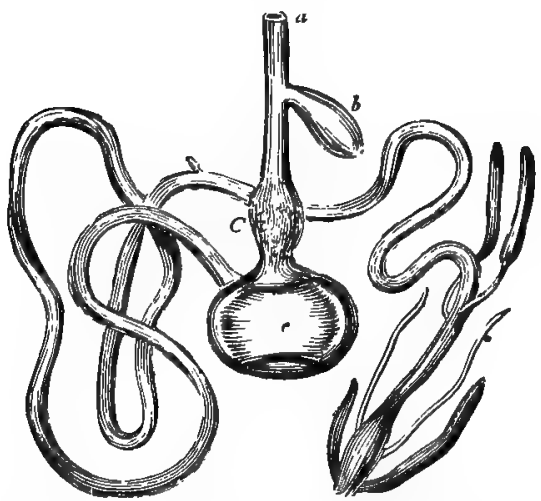

Fig. 156.-The Digestive Organs of a Bird. a, œsophagus; b, crop; $C$, stomach; $c$, gizzard.

one day. Even crows feed on insects more than on corn. Hawks and owls keep in check field-mice and frogs, gulls clean the shores of decaying matter, and many of the smaller birds live on the seeds of noxious weeds. The importance of preserving bird life cannot be easily overestimated. 
Nutrition. The processes of nutrition are carried on in much the same way as in other vertebrates. In most birds the food, when swallowed, passes down the csophagus to an enlargement called the crop, where it remains for a short time. It then goes to the stomach, which frequently consists of two parts, the proventriculus, where gastric fluids are poured on the food, and the gizzard, where it is ground. This gizzard is most highly developed in seed-eating birds, and commonly contains stones which the bird has swallowed and which grind up the food that has been softened in the crop and mixed with gastric juice in the proventriculus.

Respiration. B reat hing

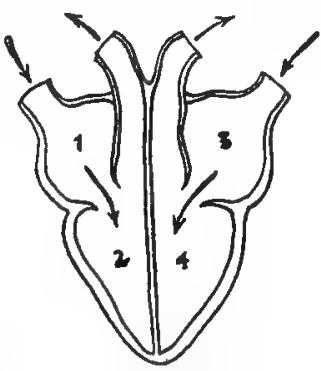

FIG. 157.-Diagram of the Heart of a Bird. occurs by lungs, the air entering and leaving because of the increase and decrease of the size of the body-cavity produced by movements of the bones and muscles surrounding it. The expansion of the lungs in breathing is very slight. The lungs connect with air-sacs which extend among the other internal organs, and even into the bones. These serve to increase the bulk of the bird without adding to its weight, thus forming a sort of hot-air balloon.

Reproduction. Eggs are produced in the ovaries, and pass from these organs through the left oviduct, the right ovary being suppressed in birds, to the cloaca and thence out of the body. The cloaca is the common cavity into which the alimentary canal, the kidneys, and the oviduct empty.

In its passage through the oviduct the egg receives from the walls of this tube its layer of white albumen and its calcareous shell. The eggs hatch outside of the body and are cared for by the parent birds with much solicitude. Except with a few of the most intelligent insects, 
there is very little attention given to the young of animals lower in the scale of life than birds. Here maternal and paternal duties seem of the greatest importance.

Discovery. The senses of birds are very keen, especially those of sight and hearing. There is an external opening to the

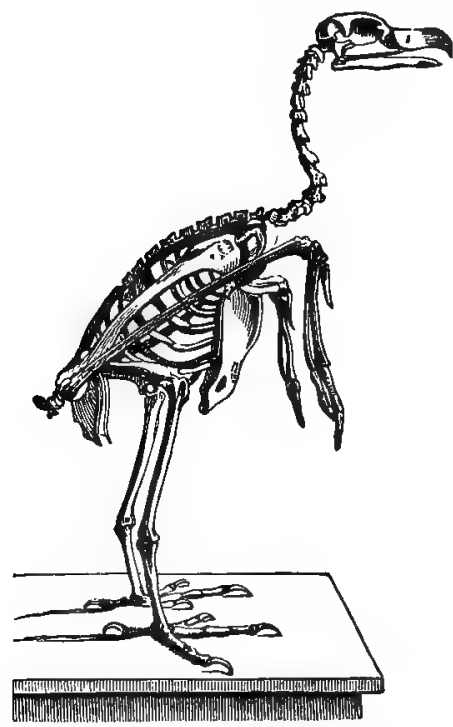

FIG. 158.-The Skeleton of a Bird. ear surrounded by regularly arranged feathers. The nervous system resembles that of the fish and frog, but the brain is much larger in comparison with the size of the body, the cerebrum and cerebellum being greatly developed.

Motion. In this function birds surpass all other animals. $\mathrm{N}$ o t only can some birds move through the air more rapidly than the fastest express train, but others can swim most skilfully in the water, and still others are able to run faster than a racehorse on land.

Of

course, no one bird can do all these things, for when wings are greatly developed for very rapid flight, as in the swallow, feet are weak and almost useless; and when running is specialized, as in the ostrich, wings become small and of little use. The swallow does not alight even for the purpose of feeding her young.

In the wing, as we have seen, the bones resemble those in the human arm (Fig. I60). At the elbow the arm is bent, and the space between the arm and forearm is filled with a strong web bearing feathers and 
assisting in spreading the wing. There are only three fingers, and the bones of these and of the palm and wrist are so grown together that it is difficult to distinguish them. Connected with the wing are two clavicles, or collar-bones, which unite at their ends to form the wish-bone. These, with the scapulars or shoulderblades and the coracoid bones, form the pectoral girdle holding the wings in place.

While the chief organ of flight is the wing, it must be remembered that the whole body aids in aerial navi-

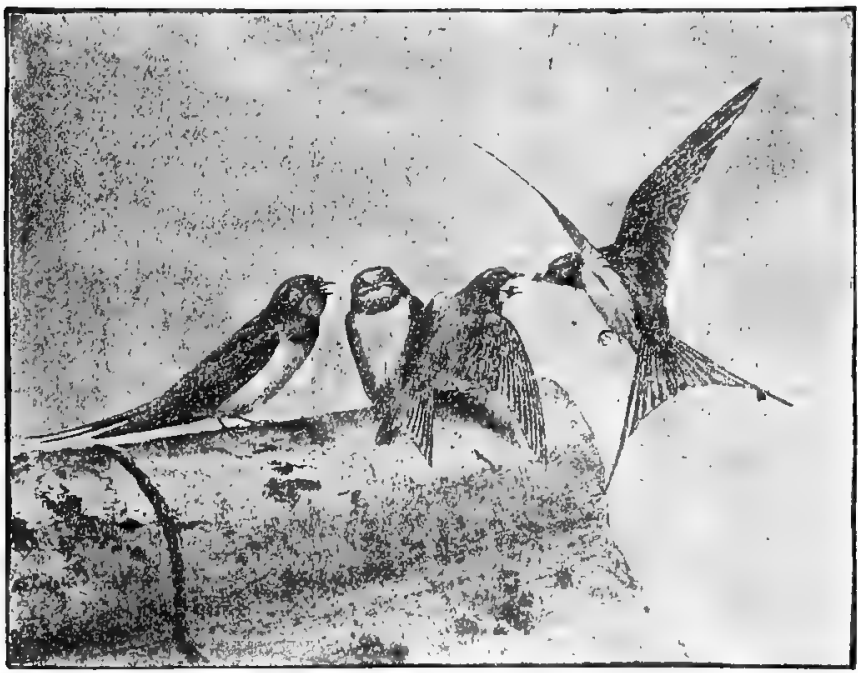

FIG. 159.-A Swallow Feeding Her Young.

gation. The sternum or breast-bone is large and strong and fastened firmly to the ribs. Its surface is often increased by a ridge of bone along the middle called the keel (Fig. I 62). The muscles of the breast attached to this sternum move the wings. These muscles are dark colored and tough in birds of great wing-power and white and tender in barn-yard fowls which have lost the power of continuous flight. 
Besides this machinery of bone and muscle, the whole body of the bird is to some extent a balloon.

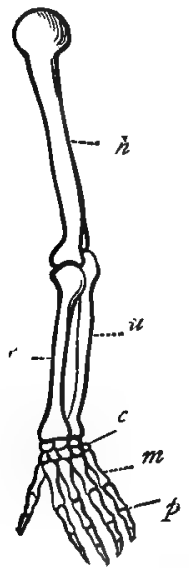

A

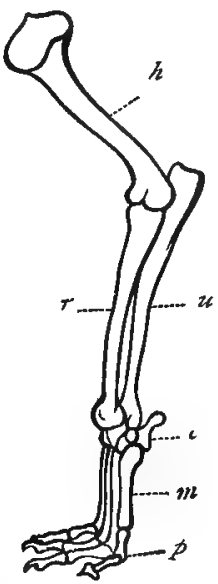

$\mathrm{B}$

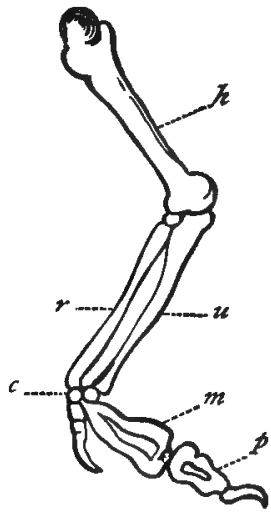

C

FIG. 160.- $A$, arm of man; $B$, fore leg of dog; $C$, wing of bird; $h$, humerus; $r$, radius; $u$, ulna; $c$, carpus $m$, metacarpus; $p$, phalanges.

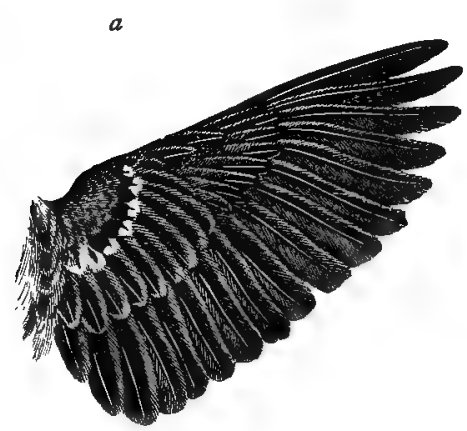

FIG. 16r.--A Bird's Wing. $a$, when flying; $b$, at rest.

The feathers increase greatly the amount of air displaced, and hence aid the buoyancy without adding 
materially to the weight. The whole plumage of a common fowl weighs only about three ounces.

Having plumage filled with air heated by the body, carrying air-sacs in viscera and bones, breathing faster than other animals, pumping blood more rapidly to all parts of its body, and with it, oxygen to replenish the internal fires, the bird easily rises on the atmosphere much as an iron ship floats on the ocean.

Other Voluntary Movements. Swimming birds have the toes webbed to serve as paddles and the form of the body is modified to fit it for motion through the water. The legs are placed farther back so that the propelling power may act from behind. In running and wading the structure of legs, feet, wings and beak are wonderfully fitted for their peculiar work.

Not only can birds move from place to place in search of food,

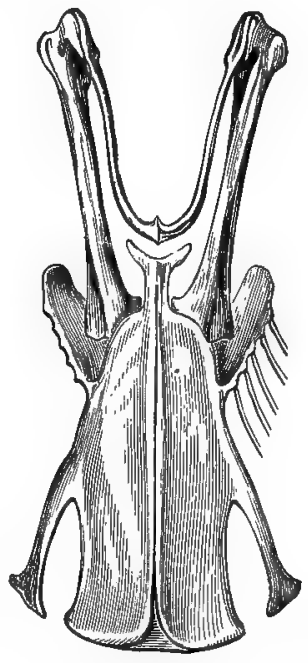

FIG. I62. - The Sternum of a Shrike. or in undertaking their long migrations, but by voluntary movements they are also able to perform skilled labor in the building of nests, to carry on warfare, and to express the most varied emotions.

Birds and Reptiles. Birds resemble reptiles in many ways. They have epidermal scales on some part of the body, the digits end in claws, the lower jaw is connected to the upper jaw by a quadrate bone, the skull is fastened to the first vertebra by a single condyle, true ribs are present, there are no gills, the eggs are large, and the digestive, reproductive, and excretory organs empty into a single cavity, the cloaca. 
Some fossil birds had teeth like reptiles, and at least one bird had a long reptilian tail (Fig. I66). Because of these resemblances birds and reptiles have sometimes been classed together as Sauropsida.

Classification of Birds. Birds have been most commonly classed in accordance with their most easily

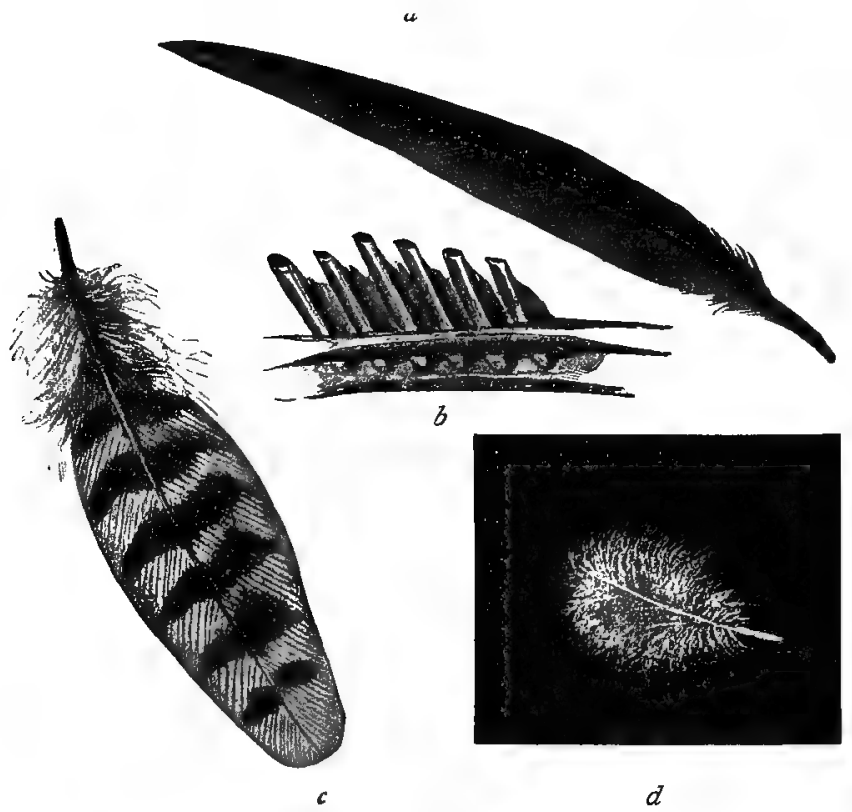

FIG. I63.-Feathers. $a$, a quill-feather; $b$, quill-feathers fastened to wing ; $c$, a shape-feather; $d$, a down-feather.

recognized points of external structure; this structure being dependent largely on the hahits of the birds.

These groups of birds are often spoken of as orders; but these orders do not correspond to orders among insects. 
I. The Running Birds (Struthii). The legs are long and the wings small. The keel of the sternum is lacking. There are two or three toes. Ostrich, emu, kiwi.

II. The Scratching Birds (Rasores). They have three toes in front, and a fourth a little higher, behind. Grouse, pheasant, common hen.

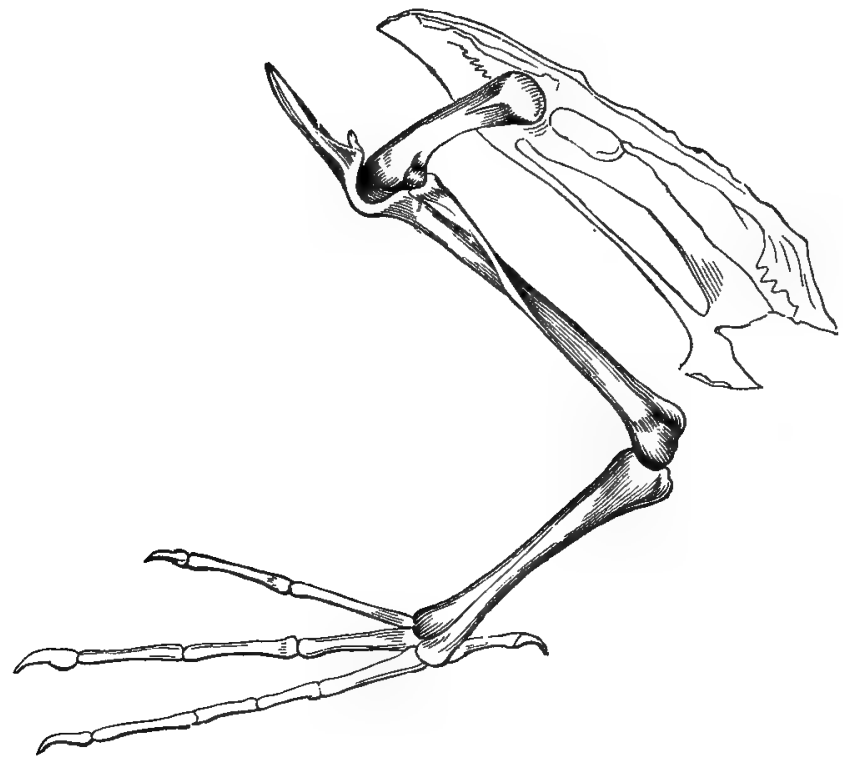

FIG. 164.-A Bird's Leg.

III. Swimming Birds (Natatores). The legs are short, and there is a web between the front toes. Penguin, duck, gulls, etc.

IV. Wading Birds (Grallatores). The tarsus is long and partly naked. The neck is also long and often the bill. Great blue heron, snipe, etc.

V. Birds of Prey (Raptores). These birds have stout curved beaks, strong feet with sharp claws, and large wings. Hawk, eagle, owl, etc. 
VI. The Pigeons (Columbinæ). These birds resemble the rasores but have weaker legs, pointed wings, and a fleshy membrane at the base of the beak. Pigeon.

VII. Cimbing Birds (Scansores). Two toes are directed forward and two backward, fitting the feet for climbing. In parrots the beak is also used for climbing. Parrots, woodpeckers.

VIII. Perching Birds (Passeres). There are three toes pointing forward and one pointing backward, all on a level. Here belong almost all our common song birds.
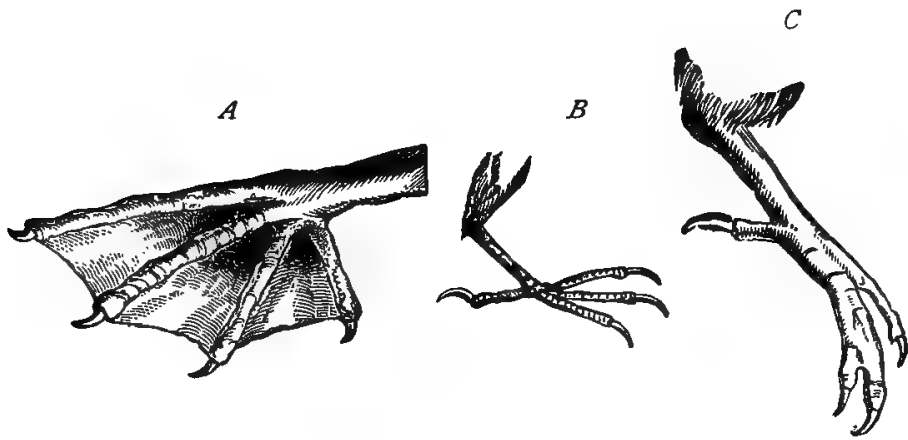

FIG. 165.- $A$, foot of a pelican; $B$, foot of a perching bird; $C$, foot of a kingfisher.

Questions. What are some common birds of very rapid flight?

What special adaptations of structure to habit among birds can you enumerate?

Why do birds migrate?

What birds should be exterminated?

What birds should be protected?

- Do birds reason?

What evidences of intelligence have you observed among birds?

Topics for Reports. A List of Birds I Know. A List of Birds I have Seen in Winter. Order in which 
I Saw New Birds in Spring. Description of a Bird I Know Edible Birds' Nests. Birds on Oceanic Islands. The Future of the Domestic Sparrow. Bird Pets. Bird Courtships. Bird Migrations. Bird Industries. Superstitions about Birds. Canaries. Domesticated Birds. Parrots. Crows. The Robin. Birds in Millinery. Uses of Gulls. What Mr. Bur-

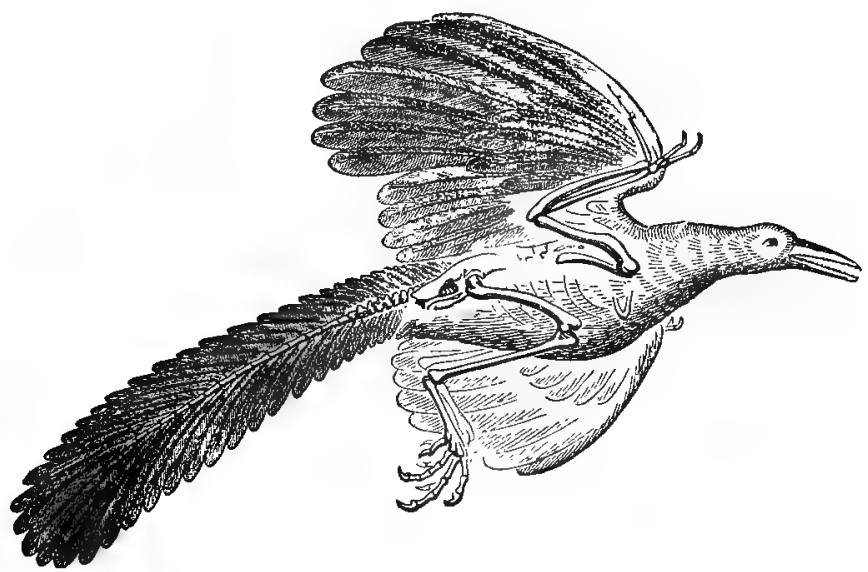

Fig. I66. - The Archæopteryx.

roughs says in "Birds and Bees and Sharp Eyes." Bird Homes. Shapes and Colors of Birds' Eggs. Length of Life among Birds. Falconry.

\section{VOCABULARY.}

Am phib'ia (Gr. amplii, around, or on both sides, and bios, life), a class of vertebrate animals breatl1ing by gills when young.

Au'ri cle (Lat. auris, ear), a chamber of the heart for receiving blood from the veins.

Barb (Lat. barba, beard), one of the side branches of a feather.
Barb'ule (Lat. dim. of barba), one of the projections along the edges of the barbs of a feather.

Bat $\mathrm{ra}^{\prime}$ chi a (Gr. balrichos, froy), another name for the Amphibia.

Car'pus (Gr. karpos, wrist), the wrist.

Clo a'ca (Lat. cloaca, a sewer), a common cavity into which the 
alimentary canal, the kidneys, and the oviducts empty.

Con'dyle (Gr. kondylos, knuckle), a bony projection.

Eusta'chi an Tube, a passage from the throat to the ear.

Fe'mur (Lat. fenzer, thigh), the thigh-bone.

Fib'u la (Lat. fibula, a clasp), the outer of the two bones of the leg below the knee.

Hu'me rus (Lat. humerus, the shoulder), the bone of the upper part of the arm.

Keel, in birds, the ridge of bone along the ventral side of the sternum.

Met a car'pus (Gr. meta, beyond, and carpus), the group of bones between the wrist and fingers.

Met a tar'sus (Gr. meta, and tarsus), the group of bones between the tarsus and phalanges.

O'vi duct (Lat. ovrem, egg, and duco, to lead), a tube for the passage of eggs.

Pha'lanx, pl, phalanges (Gr. phalanx, battle-line or bone of finger or toe), one of the finger- or toebones.
$R a^{\prime}$ di us (Lat. radius), one of the bones of the forearm.

Ret'i na (Lat. rete, a net), the inner coat of the eye.

Rep til'i a (Lat. reptilis, a reptile), a class of vertebrate animals.

Shaft, the midrib of a feather.

Ster'num (Gr. sternon, breast), the breast-bone.

Tar'sus (Gr. tarsos, a flat surface), the ankle.

Ten'don (Lat. cendo, to stretch), a cord or band of connective tissue usually binding muscles to bones.

Tib'i a (Lat. tibia), one of the bones of the leg below the knee.

UI'na (Lat. uma, elbow), a bone of the forearm.

U'ro style (Gr. oura, tail, and stylos, a column), the long bone at the end of the vertebral column in the frog.

Vane, the web of a feather with its shaft.

Ven'tri cle (Lat. ventriculus, dim. of venter, the belly), a chamber of the heart for forcing blood into the arteries. 


\section{CHAPTER XIX.}

MAN'S NEAR RELATIVES (MAMMALS).

WITH slight variations, the questions which follow can be made to apply to many other animals than the cat. With the limited time usually allowed for the study of mammalia, abundant material among common domesticated animals is easily within the reach of all pupils.

The Living Cat. With what is the body covered?

Do you find the same parts of fore and hind limbs as in the frog?

How many toes has the cat on the fore foot? on the hind foot?

Can the claws of the cat be withdrawn?

Can the claws of a dog be withdrawn?

On your own hands where are the parts corresponding to the pads on the fore foot of the cat?

Can you find the cat's elbow, wrist, knee, and heel ?

Does the cat ever walk or creep with the heel touching the ground?

In the human body the tendon of Achilles is the strong band connecting the heel with the muscles of the calf of the leg. Can you find this tendon in the cat?

Are the cat's vertebræ capable of more or less motion than those of the frog? Than those of a bird ?

Do the vertebræ extend into the tail?

Does the sternum seem as large as in most birds? Why should there be a difference? 
Do both upper and lower jaws move? Can the jaws move sidewise?

How many teeth has a cat? How do they differ in shape from those in the human body?

The dental formula for man is written $i \frac{2}{2}, c \frac{1}{1}, p m \frac{2}{2}$, $m \frac{3}{3}$. This means that in man there are in each halfjaw two incisors, or cutting teeth, one canine or pointed tooth, two

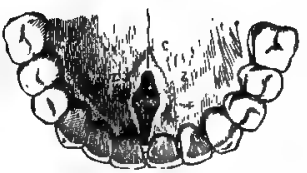

FIG. 167.-Teeth of Man. premolars, small grinding teeth, and three molars, large grinding teeth. Write the dental formula for the cat.

What peculiarity do you notice about the tongue of the cat?

Are the long hairs near the cat's mouth especially sensitive? Do you think they are of any use to the cat in searching for prey?

What is the shape of the external ear of the cat? In what direction do the ears point? Are they better fitted to hear noises in front or behind?

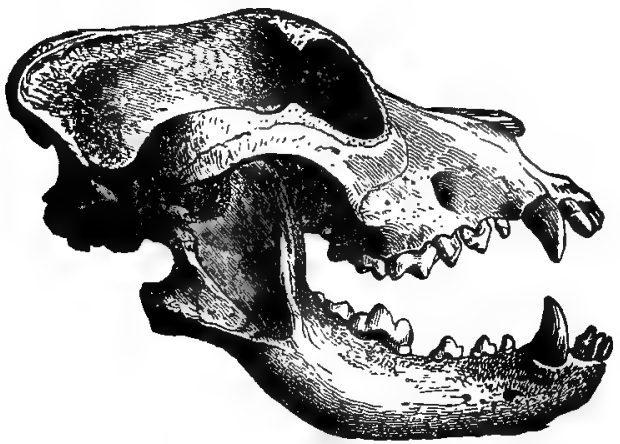

Fig. 168.-Teeth of Dog.

How do the cat's ears compare with those of a rabbit? What difference in habit may be indicated by the difference in ears? 
In the cat's eye can you make out the cornea (white of eye), the iris, and the pupil ?

Is the pupil of the cat's eye of the same shape at

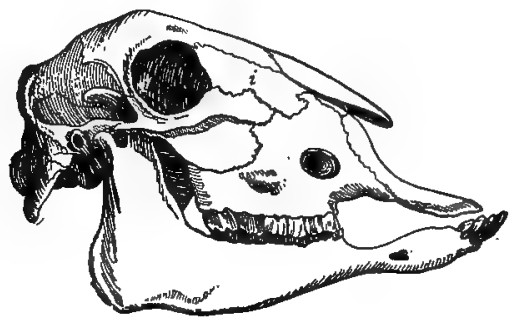

Fig. I69.-Teeth of a Sheep.

midday as at night? How do you account for the difference?

Do you find the rudiment of a nictitating membrane?

Does the cat have an acute sense of smell? What reasons have you for your answer?

How does the cat nourish its young?

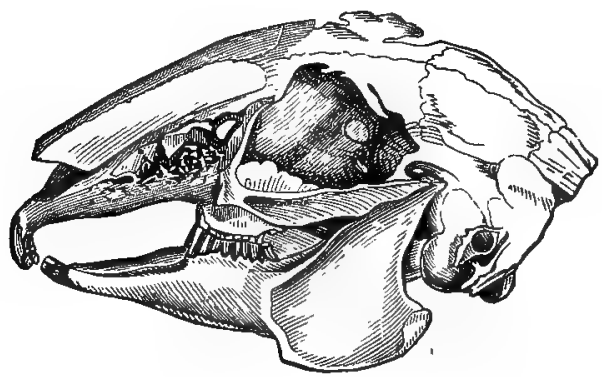

FIG. 170.-Teeth of Hare.

Summary of Drawings. seen at noon, and at night.

(a) The eye of a cat as

(b) Sole of fore foot of cat showing pads. 
Using the same questions as have been used concerning the cat, except such questions as obviously do

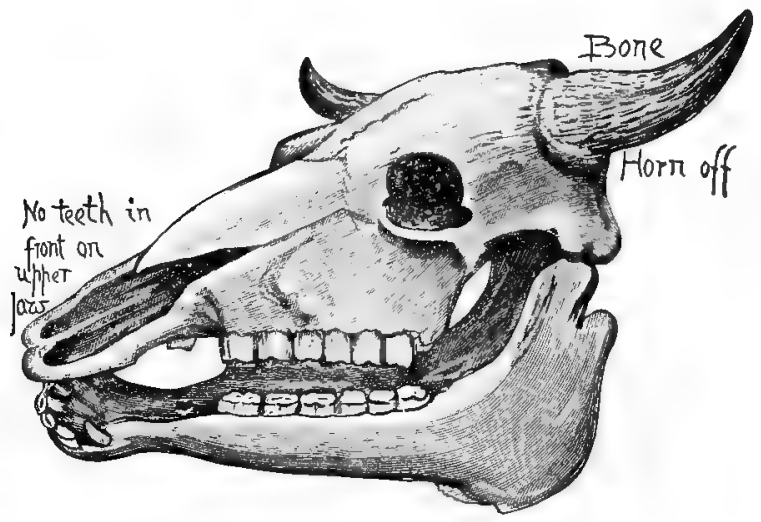

FIG. I7r.-Skull of Cow Showing Teeth.

not apply, write a description of the horse. Answer also these additional questions:

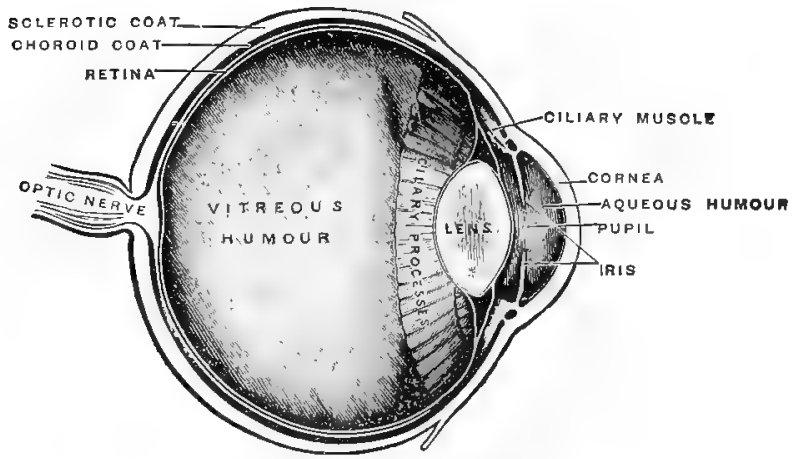

FIG. 172.-The Human Eye.

How does the food of a horse differ from that of a cat? How do the teeth differ in shape? 
How does the end of the horse's toe compare with the cat's toes?

How does the distance between heel and end of toe

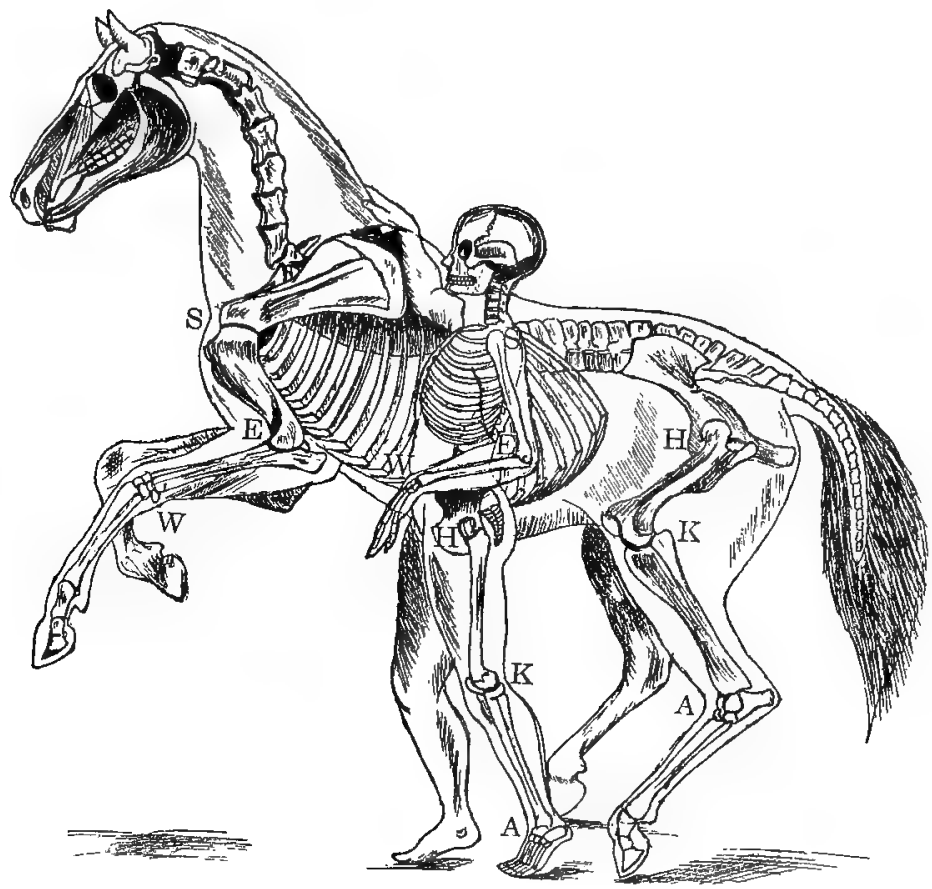

FIG. 173.-Skeletons of Man and Horse. After Flower. $S$, shoulder; $E$, elbow; $W$, wrist; $H$, hip; $K$, knee; $A$, ankle.

on the horse compare with the same measurement on the cat?

What difference in habit corresponds to the difference in structure of the foot and leg?

Write resemblances and differences for horse and cat. 


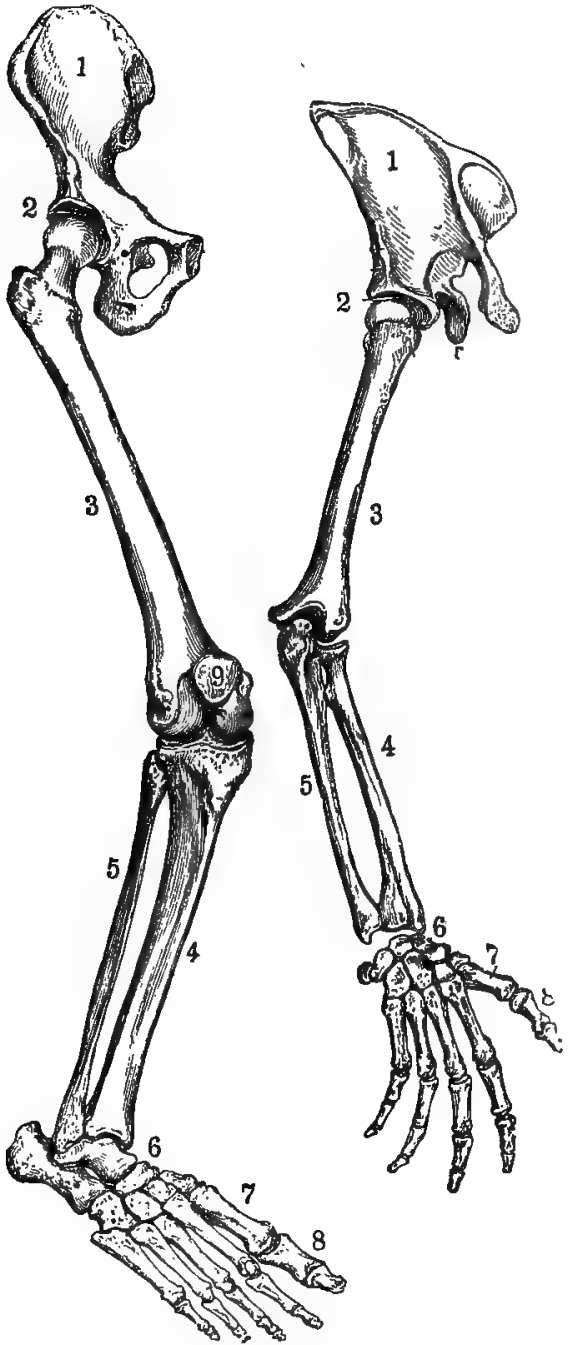

FIG. I74.-Bones of Leg and Arm of Man.

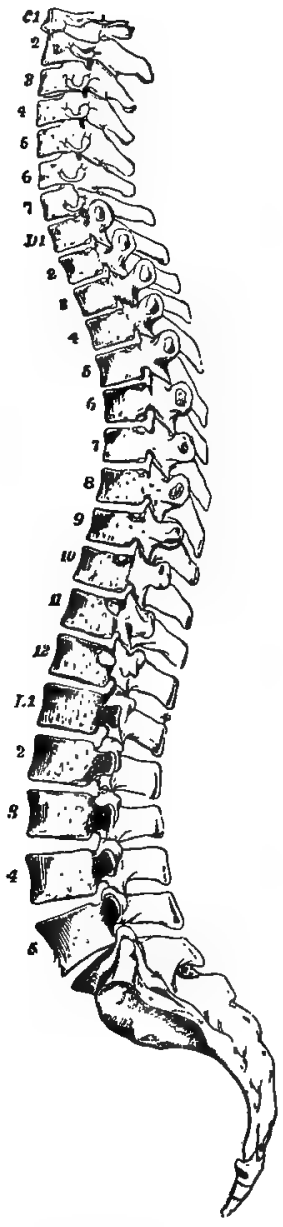

FIG. 175.- Vertebral Column of Man. $C$, cervical: $D$. dorsal; $L$, lumbar. 
Summary of Drawings. (a) Side view of fore and hind leg of horse.

(b) Side view of head of horse.

Other Mammals. As far as possible the above questions should be answered for the rabbit, squirrel or

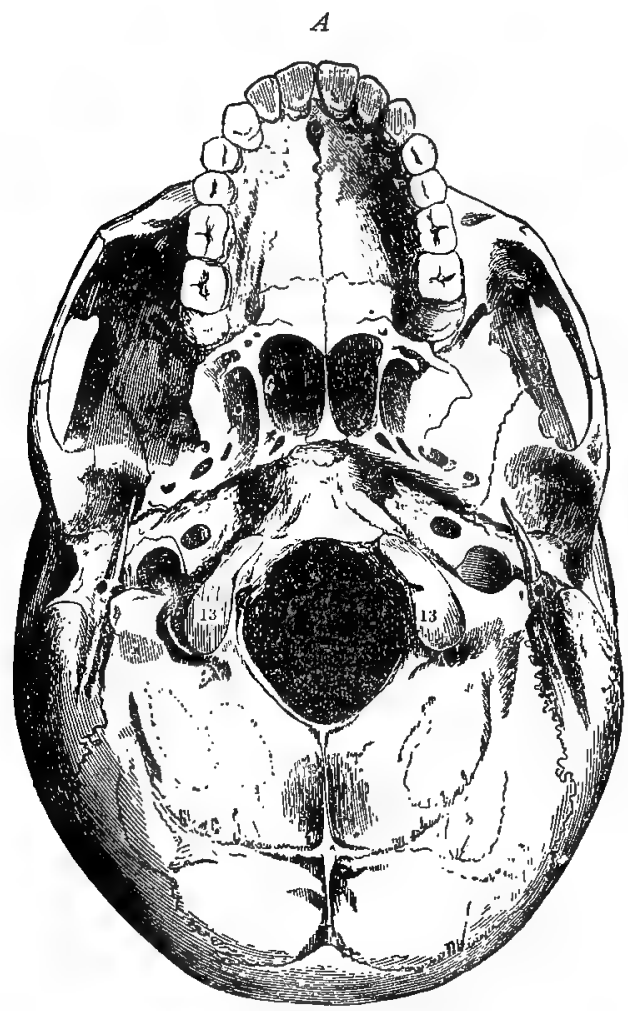

Fig. 176. - Human Skull. $A$, base of skull showing condyles at $\mathbf{1 3}, 13$.

mouse, cow or sheep, and several other mammals which can be easily observed by the pupils. 
The Mammalian Skeleton. For this study the class should be provided with at least one entire mammalian skeleton. A sheep's head, with the vertebræ of the neck, and a sheep's legs may be bought at almost any market. The muscles and tendons can be easily removed after boiling. Heads and limbs of fowl, rabbits, frogs, and other ver-

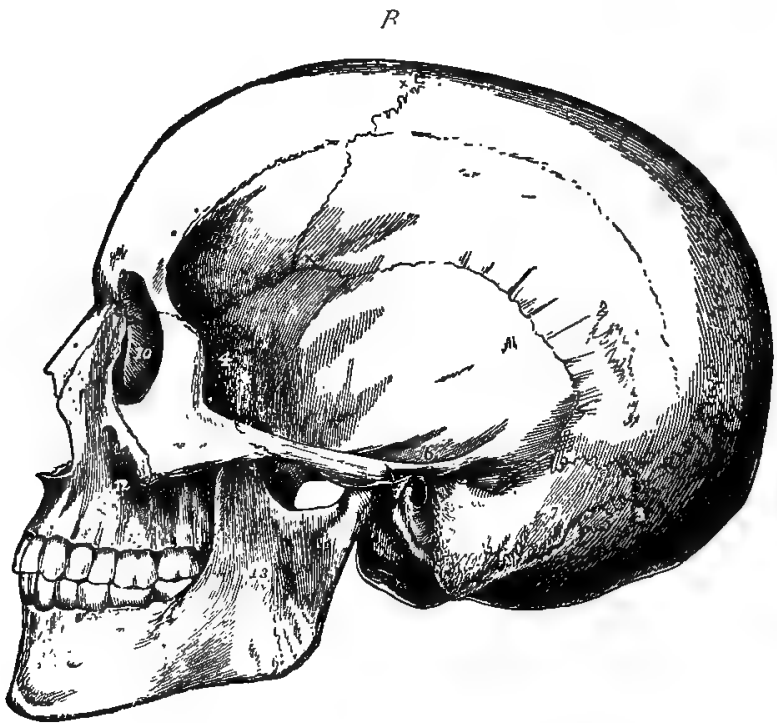

FIG. I76. - Human Skull. $B$, side view.

tebrates should also be obtained at the markets and prepared for class use. A human skeleton, or a large chart showing the bones of the human body, should be used as a basis for comparison. Indeed a number of charts, showing parts of skeletons of a variety of mammals, should be at hand. 
The Fore Limbs. The bones of the fore quarter of a sheep fastened to a board in their proper positions serve well as the objects of this study.

Do you find humerus, radius, ulna, carpal bones, metacarpal bones, and phalanges?

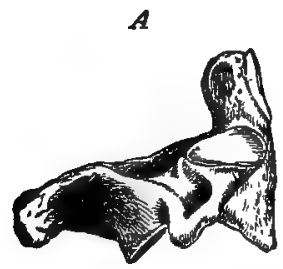

\section{$B$}

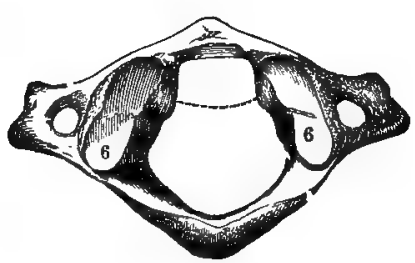

FIG. I77.-First and Second Vertebræ of Man. $A$, axis; $B$, atlas; 6, 6, sockets for condyles.

Do you find the same number of carpal and metacarpal bones as in man?

How many fingers do you find? How do they compare in position and length with those of man?

What difference in use corresponds to the difference in structure of hand and wrist in the sheep and man?

In the pectoral girdle do you find shoulder-blade (scapula) and collar-bone (clavicle) as in man? How do you account for the difference?

Drawing. Sketch of the fore leg of the sheep, naming the parts.

The Hind Limbs. Do you find femur, tibia, fibula, tarsal bones, metatarsal bones, and phalanges?

Do you find the same number of tarsal and metatarsal bones as in man? (See Fig. I74.)

How many toes do you find? How does their number compare with those in man? In the cat? In the horse? In the frog? In the turtle? 
How many bones compose the pelvic girdle?

By what kind of a joint is

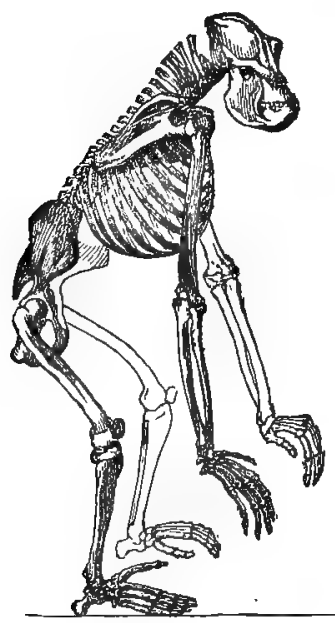

FIG. I78,-Skeleton of Gorilla. the femur attached to the pelvic girdle?

Drawing. $\mathrm{H}$ in $\mathrm{d}$ le $\mathrm{g}$, naming bones.

The Axial Skeleton. How many vertebræ compose the back-bone?

How many ribs are present?

How many of these are fastened to the sternum?

How does a mammalian vertebra compare with a vertebra of a fish?

How does the vertebral column in a mammal differ from that in the frog?

The vertebra on which the skull moves is called the atlas, the vertebra next back of that is called the axis. Can you find on the atlas smooth sockets corresponding to projections on the skull?

The projections on the skull are called condyles. How many condyles are there on the mammalian skull ? How many on the bird's skull ? What purpose do condyles and sockets serve?

Do you find a quadrate bone on the mammalian skull ?

What is the dental formula of the mammal you are studying?

What is the dental formula for the horse? For a squirrel? For a rabbit?

In the head of a horse, how does the area of face and cranium compare with the same areas in man?

(See figures.) Write resemblances and differences for skull of gorilla and man. 
(See figures.) Write resemblances and differences for limbs of gorilla and man.

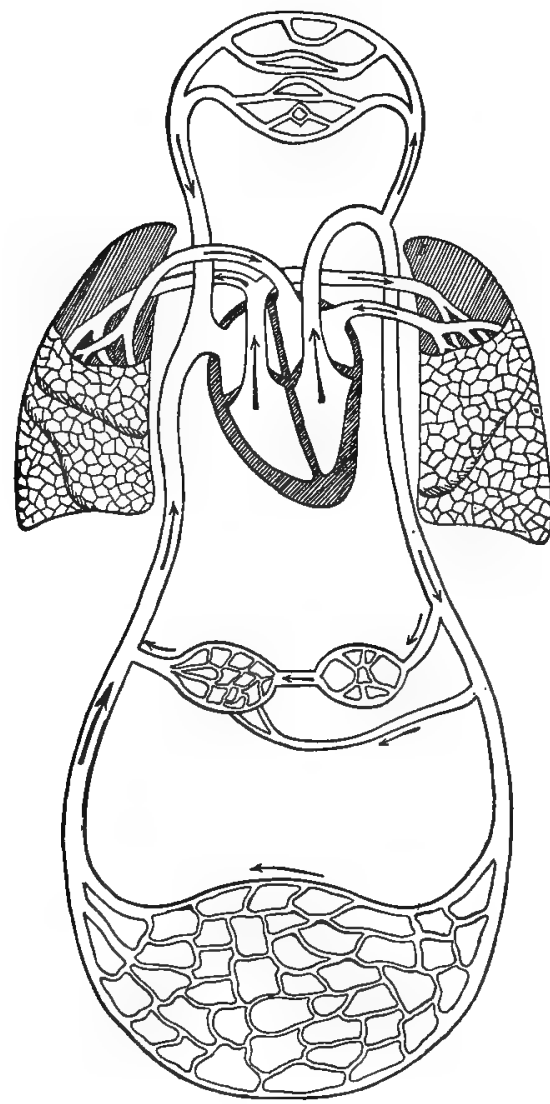

Frg. 179.-Diagram Showing Circulation of Blood in Man.

Mammalian Viscera. From a tanned or alcoholic specimen showing the internal organs of a rat or other small mammal answer these questions: 
Do you find the visceral cavity divided by a thin muscular wall (the diaphragm)? Is there a diaphragm

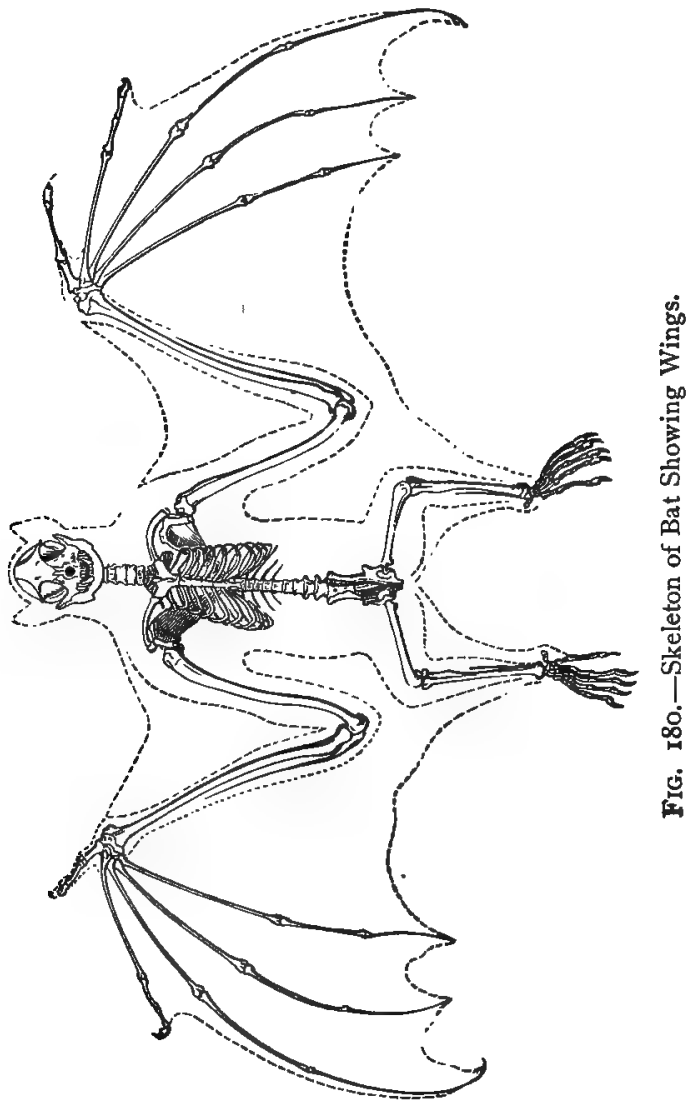

in the frog or fish? In the bird? How does the diaphragm assist in breathing?

Can you find the lungs and heart? Are they anterior or posterior to the diaphragm? 
Is the liver anterior or posterior to the diaphragm? Drawing. The internal organs in position, showing only lungs, heart, diaphragm, liver, stomach, and intestine.

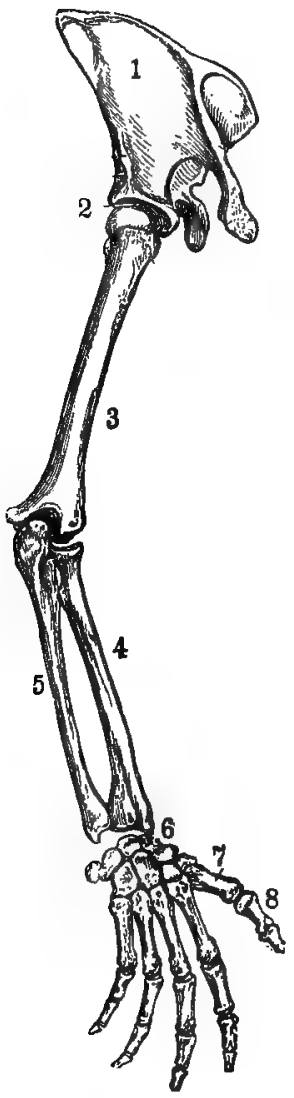

Fig. 18r. - Arm and Hand of Man.

The Class Mammalia. The mammals bring forth their young alive, and nourish them during infancy by milk secreted by the mother. They have warm blood, and in almost all cases the body is covered with hair.

The vertebræ in the mammals are usually flattened. The skull moves on the first vertebra by means of two condyles. There is no quadrate bone. All have the fore limbs, and nearly all

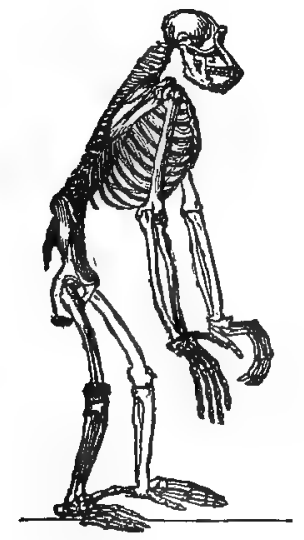

FIG. 182.-Skeleton of Chimpanzee Showing Hand.

have also the hind limbs. Normally there are five toes on each foot. Almost all mammals have teeth, 
and very many have two sets, the milk-teeth and the permanent teeth. The visceral cavity is divided by the diaphragm into two parts, the thorax or chest, and the abdomen. External ears are present in most cases. The heart has four chambers (Fig. I 79).

The nervous system differs from that of other verte-

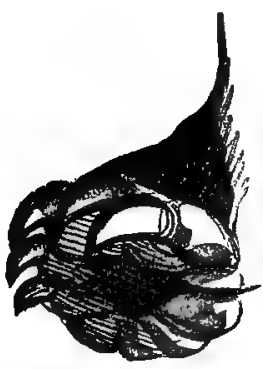

FIG. 183.-Fore Foot of Mole.

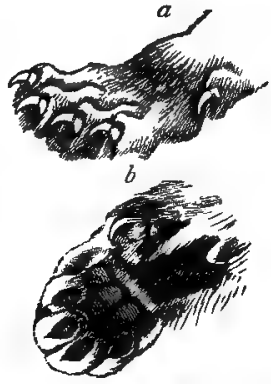

Fig. 184.-Fore Foot of Cat.

$a$, with claws extended;

$b$, with claws drawn in.

brates largely in the greater size of the cerebrum or forebrain.

Fingers and Toes. As we have already pointed out, the mammals have normally five fingers for each hand or fore foot, and five toes for each hind foot. In many different ways these digits have been changed and adapted to their special work, yet the fundamental plan of structure has remained unaltered. Our own hands are the most perfect animal tools in existence, capable of manifold and delicate movements, but they do not differ as much from the fore feet of cats, bats, or even whales as we might at first suppose. The chief point of superiority in the human hand is found in the position and scope of movement of the thumb. In some of the higher monkeys the thumb is opposed to the fingers very much as in man, but in all cases the 
power of movement is much less, and the whole hand is far more clumsy; yet the hands of men and the hands of monkeys possess almost identically the same bones,

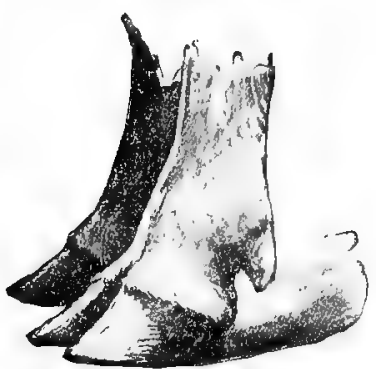

IIG. I85.-Fore Feet of Ciw.

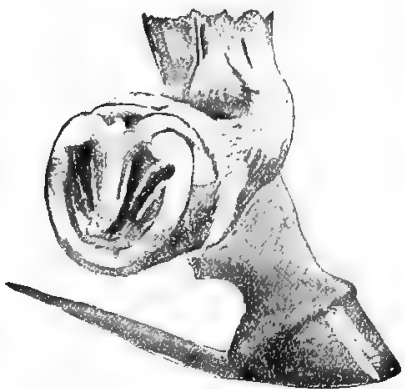

ŁIG. ז86.-. Fore Feet of Horse.

tendons, and muscles. They have also the small callous, or hard, parts of the palm, with thick cushions of fat beneath, to protect the working parts between

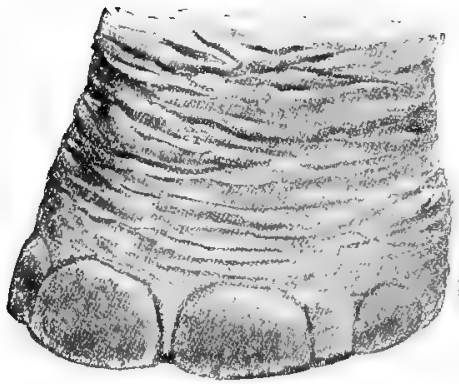

FIG. I87. - Foot of Elephant.

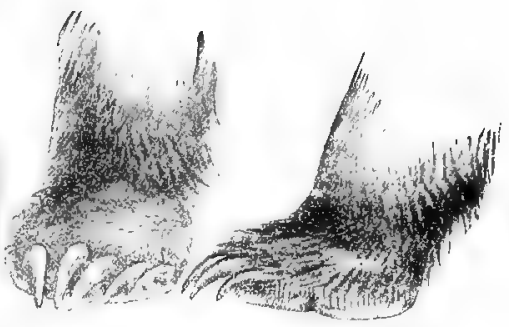

FIG. I 88.-Feel of Bear.

the outer skin and the hard bones. These callous spots are easily seen, too, in the fore feet of cats, dogs, bears, and many other mammals, and they may, with 

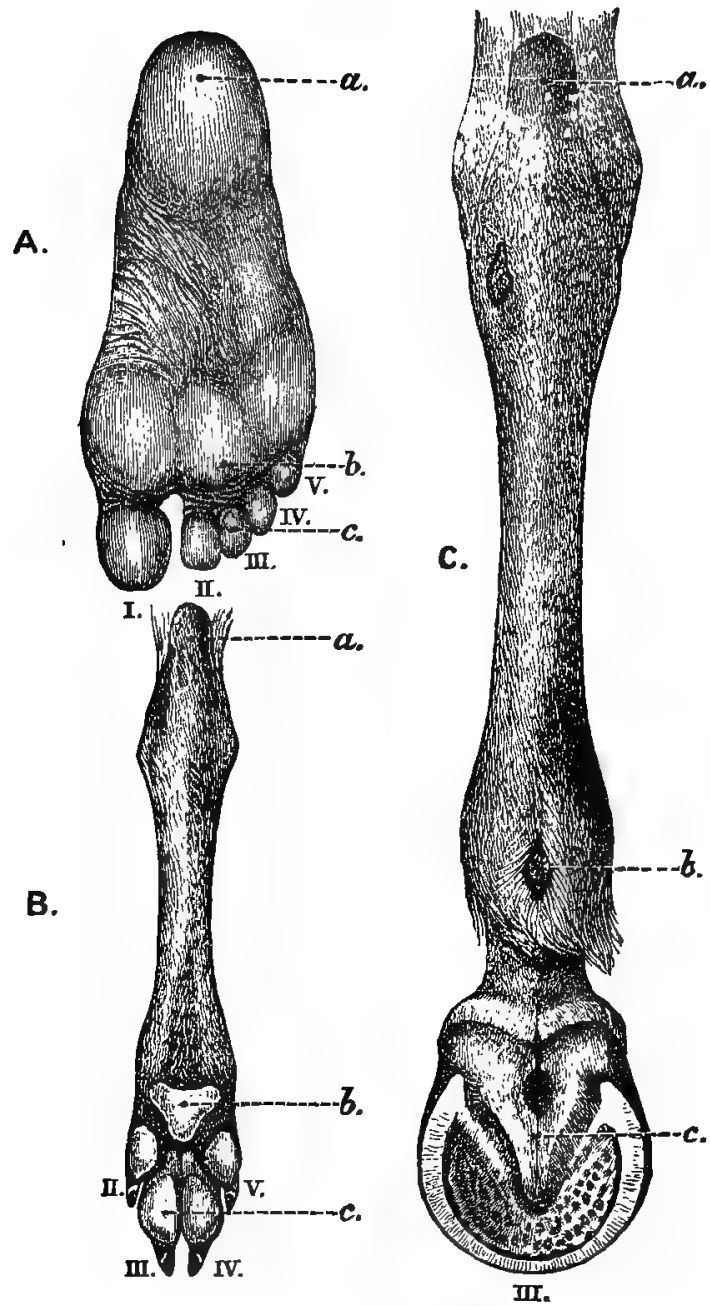

FIG. I89.- $A$, sole of foot of man; $B$. of dog; $C$, of horse; $a$, heel; $b$, callous; $c$, cushion; $I .-V$., digits. (From Flower, "The Horse.") 
some care, be found even in a hand or fore foot so much specialized as that of the horse.

Hands and Feet. As we have already found, the bones of the hind feet closely resemble those of the fore feet, or, in other words, hands and feet are built on the same plan. The palm of the hand corresponds to the sole of the foot, showing the same ridges and callosities. Animals which put the whole sole of the foot, from toe
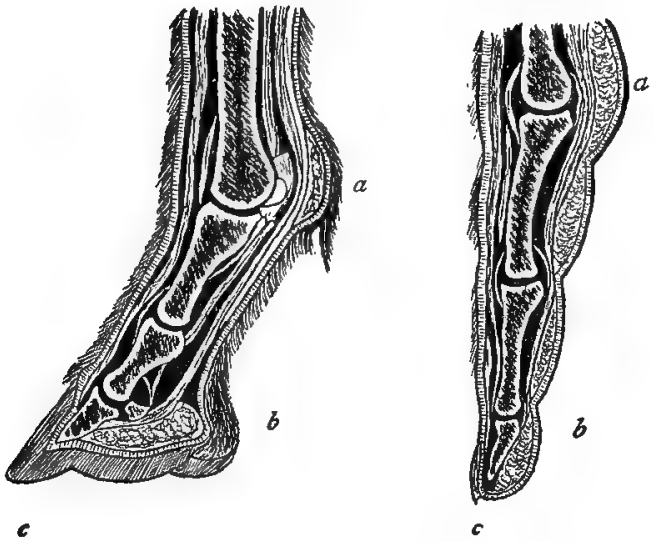

Fig. 19a-Finger of Man and of Horse. After Flower. $a$, callous; $\boldsymbol{b}$, cushion; $c$, nail.

to heel, on the ground when they walk are said to be plantigrade animals. Quadrupeds, like the bear, which walk in this way have a somewhat awkward gait. The more graceful and easy runners among beasts walk on the ends of their toes. These are said to be digitigrade animals. The horse presents an extreme illustration of the digitigrade foot, walking as he does on the ends of his middle toes and middle fingers. We, ourselves, walk on the whole sole of the foot, but when we run we rise on the toes. If we should attempt to walk on all fours, bearing the weight of the body on soles and 
palms, we could hasten only by rising on fingers and toes. Should we so rise it is easy to see that the little finger and the thumb would not touch the ground. They would hang as useless members behind the other fingers. Rising still more, the weight would rest wholly on the middle finger, and two more fingers would become useless. Something like this has probably taken place gradually in the development of digitigrade feet.

The Horse's Foot. The ancestry of the horse has been traced back very carefully for thousands of years
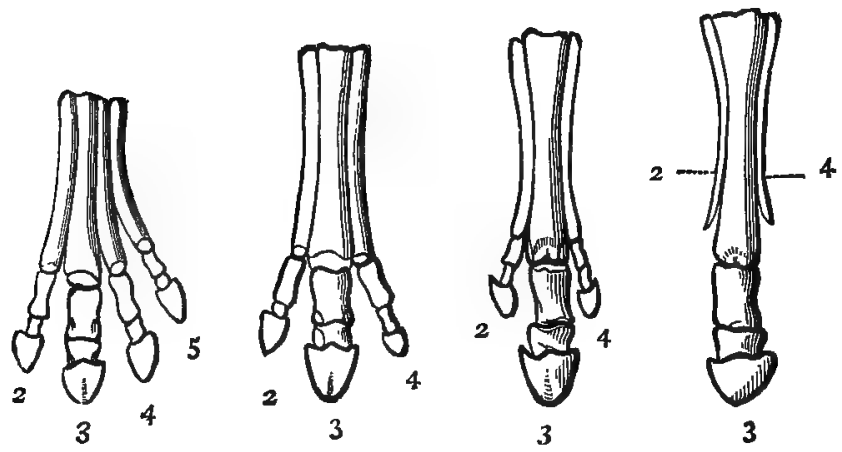

FIg. I9I.-Feet of Ancestors of Horse. The figures indicate the numbers of the digits in the five-fingered hand of most mammals.

before man dwelt upon the earth. It has been found that the horse is probably a descendant of a five-toed animal not much larger than a sheep. From this animal the line of descent has been followed down through the ages, the various forms showing the loss of toes, one after another, until only one now remains for each foot. The splint bones seen on each side of the long metacarpal and metatarsal bones of the horse are all that remain of the two toes which last disappeared. 
Growth from the Epidermis. Hair, claws, hoofs, and horns are all made of the same substance as our own finger-nails. All are modifications of the epidermis or outer skin. In its growth a hair dips down into the true skin, forming a papilla which is sunken into the dermis or true skin. This papilla is provided at its base with glands for oiling the hair, muscles for erecting, blood-vessels for nourishing, and nerves for
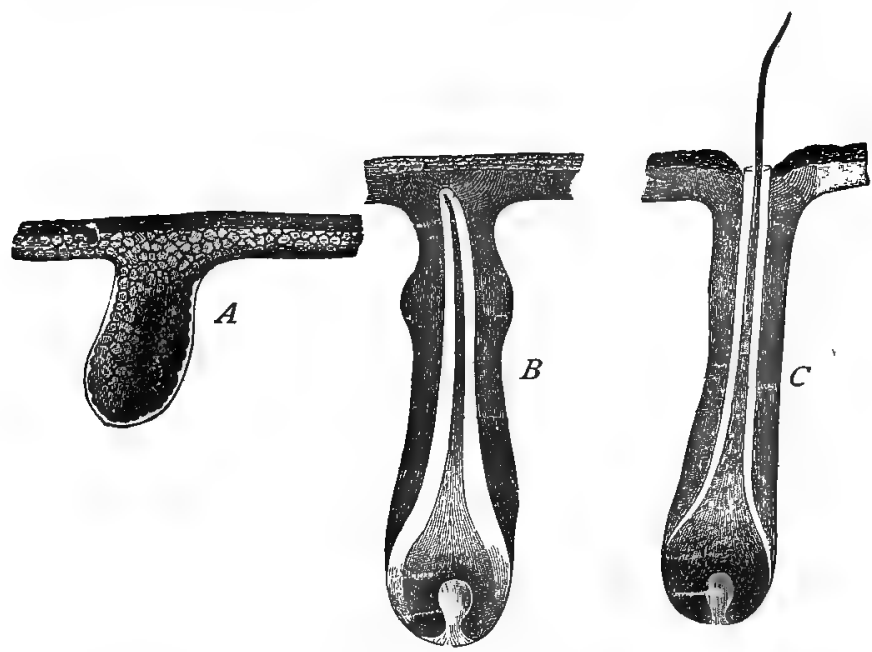

FIG. 192.-Growth of Hair. $A$, hair-rudiment; $B$, hair-rudiment with young hair formed, but not yet risen through the cuticle; $C$, hair protruded.

warning. When the hair is long and twisted we call it wool, when smooth, fine, and soft we call it fur. On the pig the coarse, straight hairs are called bristles. The quills of a porcupine are stout hairs with sharp points, very useful to the animal in defending itself from enemies. Hairs are colored by pigment-cells found in each hair. Commonly among wild animals the color of the hair serves to conceal the wearer from enemies; 
in many cases even changing with the seasons to afford a better protection. The arctic fox and the northern hare become near as white as snow in winter. It has been found that the fact that most animals are lighter in color beneath than above is really a device for concealing them.

Horns. These defensive weapons are formed from the epidermis in much the same way as hair. In

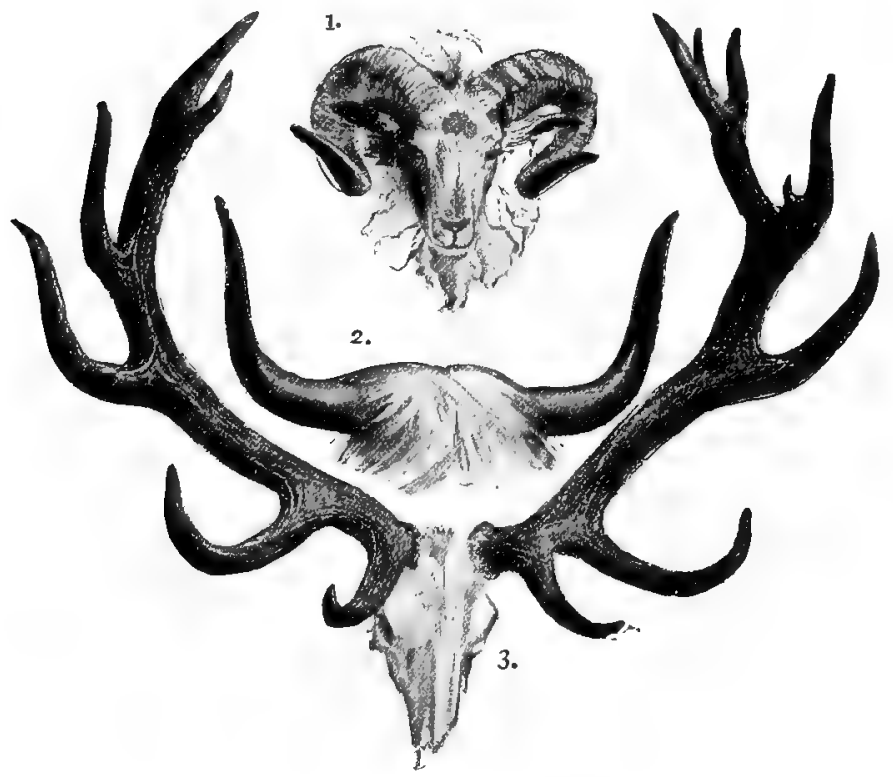

FrG. r93.-I, horns of sheep; 2, horns of cow; 3, horns of deer.

domestic cattle the horns have an interior core of bone over which the skin of horn fits. The horns of deer are solid, but in the velvet are covered with epidermis. They fall off each autumn and grow again in the spring.

Structure of Teeth. The teeth of mammals are composed chiefly of a bony substance called dentine, 
and a harder substance called enamel. In a human tooth the enamel covers entirely the outside of that part of the tooth known as the crown. The root, or fang, of the tooth is covered by a substance called cement. The greater part of the tooth is dentine. In the teeth of many animals which nust grind their food for a long time the enamel and dentine are so folded together that hard sharp ridges of enamel are produced above valleys. When these valleys are deep they are filled with cement, as in the case of the molar teeth of

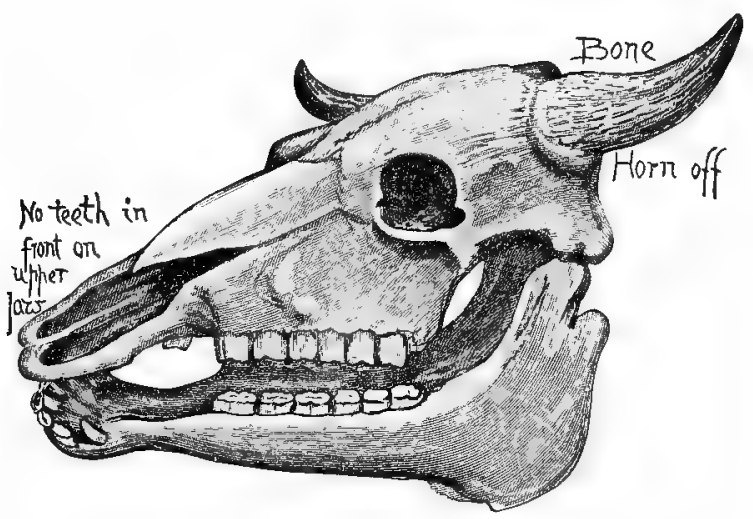

Fig. 194.- Skull of Cow Showing the Bone of the Horn.

the horse. As these teeth wear away the dentine and cement wear faster than the enamel and the ridges become more prominent.

Gnawing animals, like the squirrel, have teeth fitted with enamel in front and dentine behind. As the teeth are used the dentine is worn away and a sharp chisel of enamel is produced. These teeth constantly increase in length from below, and, if they are not worn away fast enough, they sometimes grow so long that they cannot be used at all and the animal starves. In every 
animal the teeth seem to be especially adapted for the work they must perform.

Questions. Refer to Figs. I78, 195, and 196.

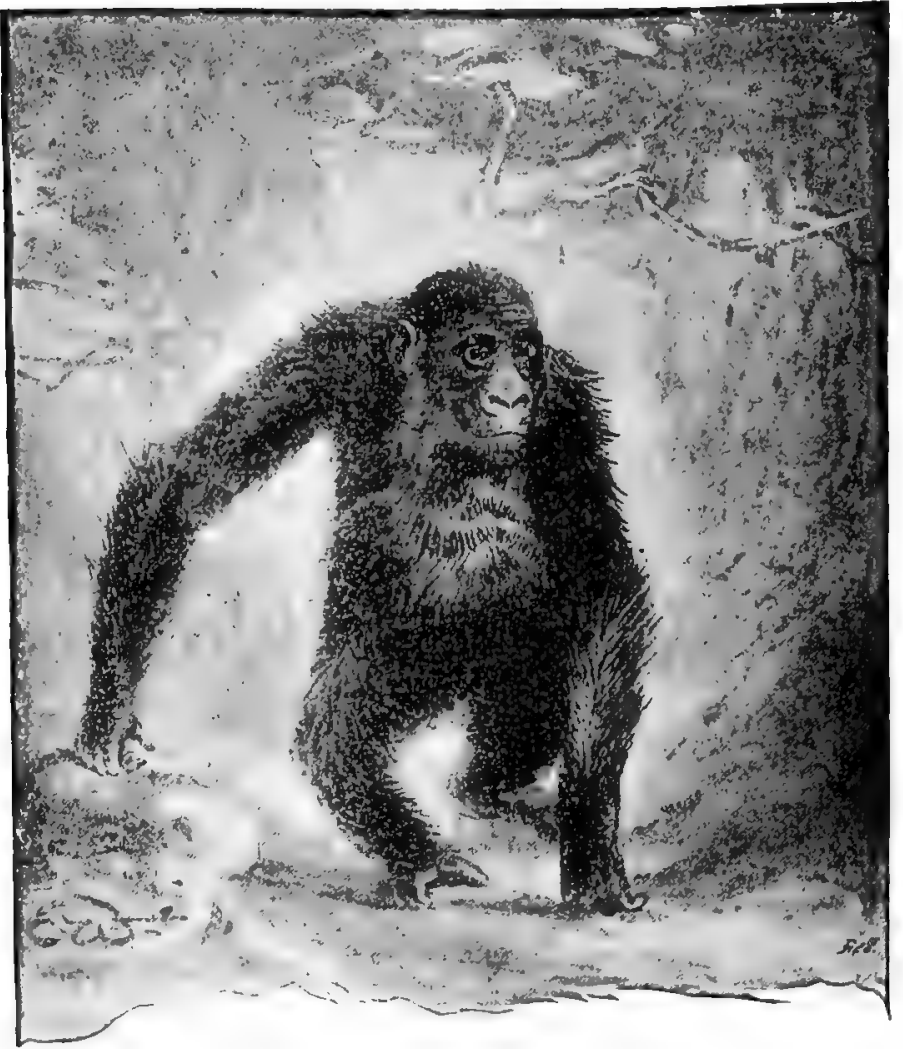

FIG. 195.-A Manlike Ape Walking.

In what way does a gorilla or a chimpanzee resemble man?

How does man differ from these animals? 
In what respects are the monkeys peculiarly well fitted for their environment?

How do monkeys differ from dogs?

In the struggle for existence what advantages do

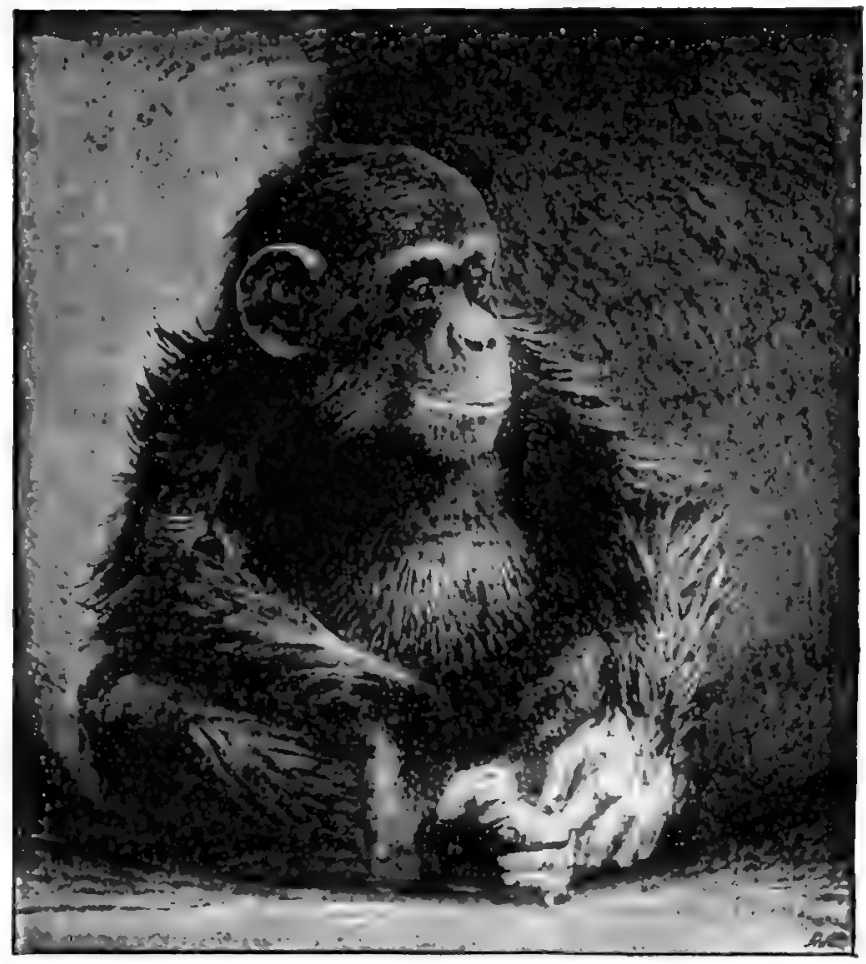

FIG. 196.-A Chimpanzee.

monkeys have over dogs? What advantages do dogs have over monkeys?

How do monkeys differ from horses?

In what respects do they resemble horses? 
What are the most easily recognized characteristics of Fishes ? of Amphibians.? of Reptiles ? of Birds ? of Mammals?

What is the dental formula of an animal you have examined?

How do the teeth of a cow differ from those of a squirrel ?

How does hair differ from wool? 
MAN'S NEAR RELATIVES' (MAMMALS).

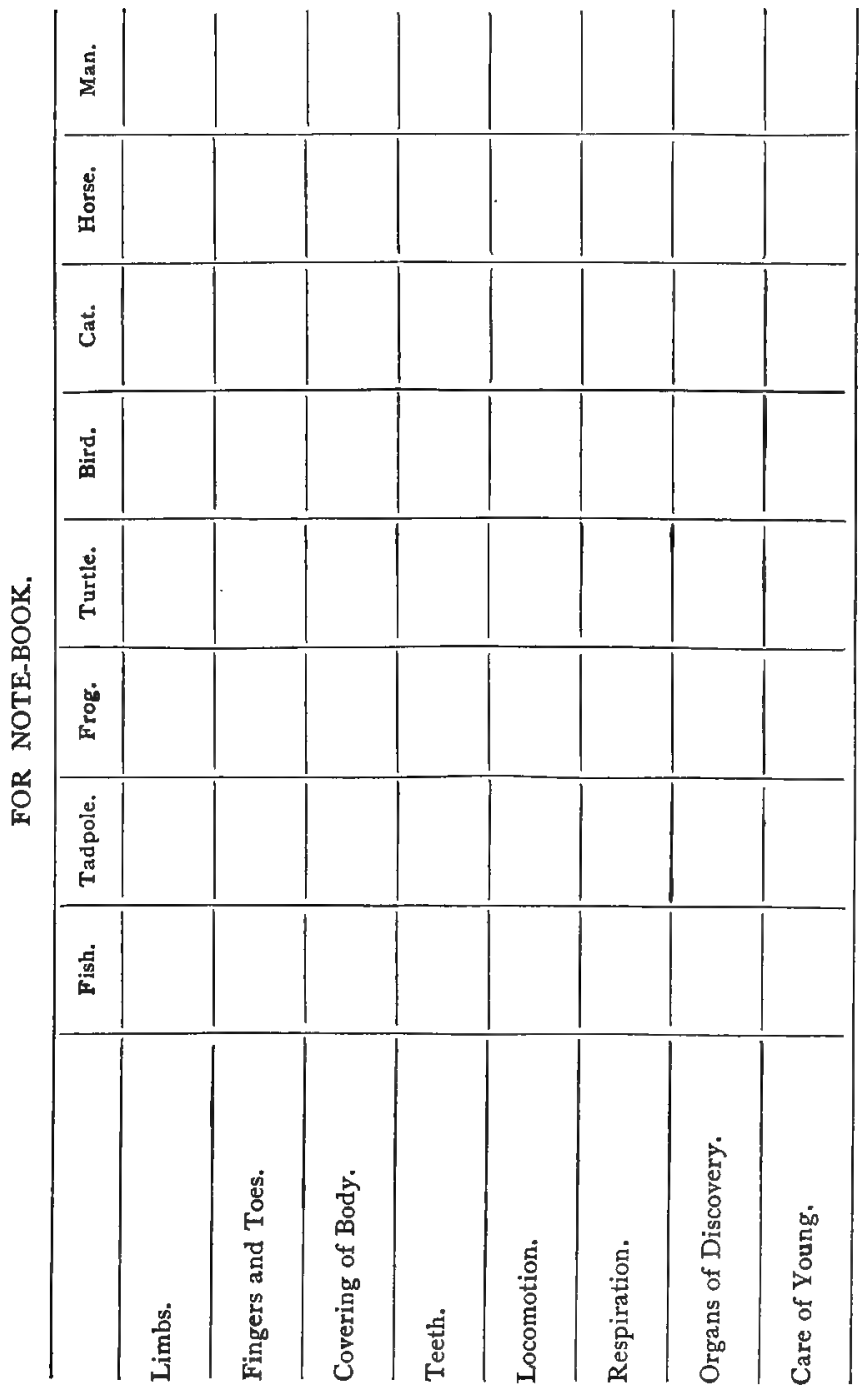




\section{CHAPTER XX.}

\section{THE DISTRIBUTION OF ANIMALS.}

Distribution in Land, Water, and Air. We have already discovered that we must look in different places to find different animals. We should not think of searching for bees in a desert, nor for cockroaches in the fields along with grasshoppers and crickets. We have learned that the larvæ of dragon-flies and mosquitoes live in the water, while the full-grown insects inhabit the air. We do not expect to find caterpillars either swimming or flying. The place in which an animal lives is called its habitat. Animals living mostly in the air are said to be aerial, those inhabiting the dry land terrestrial, and those dwelling in the water aquatic. Aquatic animals may be either freshwater or marine forms.

Distribution in Altitude. In either of the above cases the distribution seems to be influenced by altitude, or, as we speak of it in the case of aquatic animals, by depth. One species of butterfly is found only on the summits of the White Mountains in New Hampshire; others are always seen flying near the ground in the valleys, while still others live in mid-air. Among marine animals this dependence on altitude is very marked. If the piles of a wharf be examined at low tide we find the animal life marked off into distinct zones parallel with the various levels of the water.

Distribution Over the Earth's Surface. We are familiar with the fact that certain animals are characteristic residents of definite portions of the world. Animals belonging exclusively to arctic, temperate, or 
tropical regions are well known to every intelligent person. In the same zone, too, different regions vary greatly in the life they support. The bison and grizzly bear belong to North America. The gorilla is found only in the forests of the western coasts of Africa. New Zealand has no native mammals except bats. Monkeys with prehensile tails live only in the New World. Continents have animals very different from those living on islands very near their borders.

On the other hand, the domestic fly flourishes everywhere, and the house-sparrow seems to thrive as well in America as in Europe. Distribution over the earth's surface is often called Geographical Distribution.

All the animals inhabiting a given region constitute its fauna, just as the plants inhabiting a locality constitute its flora.

The entire region inhabited by a certain kind of animal is often called its area of distribution. In the case of animals which migrate or wander from place to place the area of distribution may be spoken of as the range.

Dispersals. In modern as well as in ancient times many animals have greatly extended the areas in which they live. The changes made in recent years have been carefully studied, to furnish a guide in explaining the movements of animals in the past. Doubtless many of the same causes which influence animal distribution now have been always active.

The Milkweed-butterfly. The milkweed-butterfly is an American insect. In about the year I845 it first appeared in the Hawaiian Islands. At about the same time its special food-plant (Asclepias) appeared and became a troublesome weed. This butterfly soon spread over many of the Pacific islands, following the spread of its food-plant. It has also extended eastward to Bermuda, and is sometimes found in England and France. In this case the dispersal has been aided by commerce; for the seeds of the food-plant as well as 
the eggs, or young, of the butterfly were doubtless transported in cargoes carried by ships. It is interesting to note, however, that the animal follows the spread of the plant on which its larva lives.

The Colorado Beetle. This insect, which was first described in 1824 , was then found only in the neighborhood of the Rocky Mountains. Its food then was a wild plant, the sand-burr (Solanum rostratum). When the potato in its westward journey reached this beetle, the insect eagerly adopted the new food. For about forty years the potato-beetle has been extending its ravages, until it now flourishes in large numbers throughout the United States and Canada, apparently defying man's best efforts to keep it in check. Here a change in the food-plant seems to have been responsible for the change in distribution.

Some Causes of Dispersal. As shown by the cases just described, dispersal is often brought about by changes in food. Indeed, most of the wanderings of animals are doubtless prompted by some impulse connected with food-supply. Other causes, however, like pressure by enemies, change, in climate, overcrowding, perhaps even the curiosity of the animals themselves, have been instrumental in bringing about migrations. The regular migrations of birds, during which many thousands of our common birds travel half the length of a continent in a few weeks, or possibly a few days, or the somewhat similar migrations of fish, have not yet been fully explained.

Barriers. Rivers, seas, and sometimes mountains have often prevented some of the animals of a region from getting far away from their home areas. These restricted animals often characterize a region. In a somewhat arbitrary manner naturalists have divided the surface of the earth into areas of distribution, for greater convenience in studying the causes which have brought our present faunas to their present places. These areas are often shown by maps. 
Islands. The ocean is a barrier which land animals seldom cross. Because of this, islands far from continents have both a fauna and a flora differing from that of the nearest mainland, and differing also from one another. Frogs and toads are not found on oceanic islands because salt water has prevented their migration to these places. Bats, birds, and butterflies may, however, overcome more easily the barrier of the sea, and make their homes on these islands. Some large islands, like New Zealand, show faunas curiously resembling the ancient faunas of Europe or America. Doubtless, in such cases, the barrier of the sea has preserved the ancient life by preventing the incoming of strong invaders. Because of facts like these island faunas are of great importance to Zoölogists.

Isolated Tracts. Other regions of the earth may resemble islands in their animal life because they are surrounded by barriers which certain species cannot cross. Thus, the part of a river above a cataract will have aquatic animals different from those below the falls.

Most arctic animals perish when brought to southern climates. Animals living in the lowlands of equatorial regions cannot live on the highlands. Thus heat and altitude may prove as effective barriers as the sea itself in isolating species. All over the world there are tracts characterized by the presence or absence of certain plants or animals.

Wanderings. Whenever an animal wanders into an unfamiliar region, differing from its original habitat, we wish to know what causes operated to bring about the change of location, how the animal supports its life under the new conditions, whether it is likely to exterminate or reduce the numbers of any of the original inhabitants of the locality, and, finally, whether its own structure will be gradually modified to adapt itself better to the new conditions of life. In regard to many cases of change of dwelling-place these questions 
have been answered. The Colorado beetle has been able to maintain itself under new conditions. The domestic (English) sparrow thrives in America. In these cases the creatures have adapted their mode of life to new habitats with marvellous rapidity and success. Foreign rats have practically exterminated American species, being able not only to survive, but to drive out animals already adapted to their environment. Fishes in caverns have lost the use of their eyes, either from lack of use, or because eyes in absolute darkness are a disadvantage, and so disappear by the process of natural selection.

Structure and Habitat. In the chapter on Insect Adaptations we have called attention to the fitness of organs for the work they must perform. At first thought it might seem as if these insects had been fitted from the start for their peculiar mode of life. But a little reflection must show that many of these adaptations, however ingenious they may seem, are really very imperfect. The breathing-organs of aquatic insects are clumsy, compared with the gills of a fish. In fact, they are soon seen to be modifications of organs intended for another purpose, namely, for breathing air. If, then, we were to hold that animals were originally adapted for the localities in which we find them, the useless eye of the blind fish in a cavern would be to us an insoluble problem. Fish made on purpose for. life in dark caverns should have no eyes, no optic nerves, and no useless muscles to move the eyeballs. The fact that all aquatic insects have trachere admits of no reasonable explanation unless we assume that these insects are descended from air-breathing ancestors. Such ancestors may have entered the water in search of food, or to escape enemies. In either case, those whose trachea were best fitted to use the air dissolved in the water survived, while their kindred perished.

The obvious inference from the facts of distribution 
is that the great majority of animals now inhabiting the world have become adapted to their present environment through gradual changes in structure.

Geological Distribution. It is doubtless true that the present distribution of a species has resulted from the conditions of its past distribution, even to the remotest times. Thus time becomes an important factor in the study of animal life. This is especially so if it be true that natural selection has operated in bringing about other changes, just as it has in altering the color of butterflies. Distribution in time is often called Geological Distribution. Indeed, to really understand an animal structure we need to study not only its present ways, but also the history of the struggles of its ancestors. In one way or another habits, structure, adaptations, and present and past distribution are so closely connected that while studying one we must study all. 


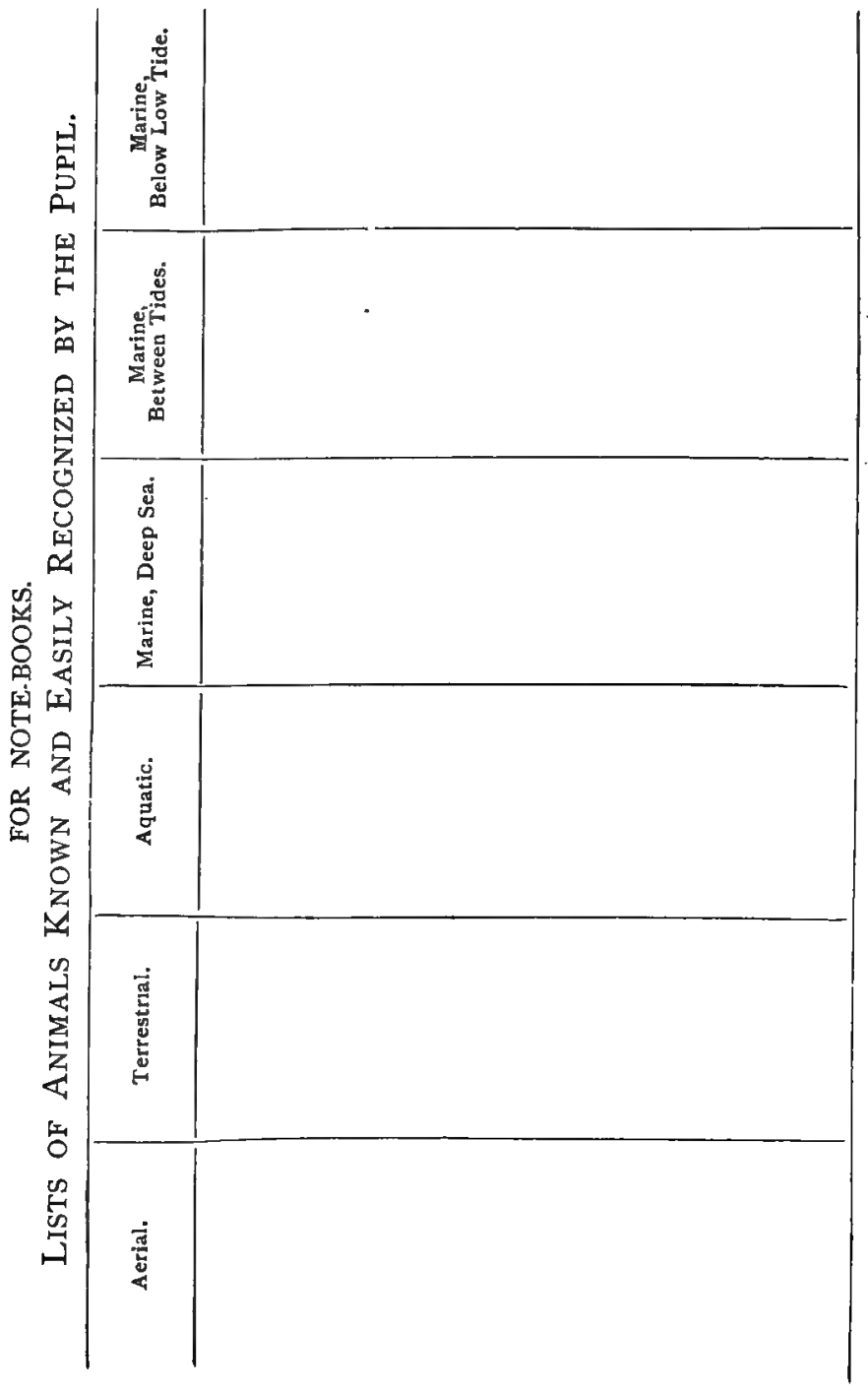




\section{CHAPTER XXI.}

\section{ANIMAL RELATIONSHIPS.}

Classification. In the earlier days of zoölogical research, animals were classified by their resemblances and differences as shown by adult forms. As information concerning animal structure increased it became more and more difficult to arrange schemes of classification. The well-known classification of Cuvier divided the whole animal kingdom into four great groups: Radiates, Mollusks, Articulates, and Vertebrates. This classification assumed that species are changeless, and the subject of kinship was not considered of so great importance as it is now.

Because of the increasing study of relationships, these groups were gradually abandoned for new ones. Radiates became Protozoa, Porifera, and Cœlenterata; and Articulates became Arthropoda and Vermes. Many other changes have been made, and similar changes are constantly being made, because relationship by descent is now thought to be of so great importance. Indeed, relationship is nowadays considered to be of far more consequence than classification.

Structure. Resemblance in structure must always be the most important guide in discovering relationship, as it has always been the basis of classification. But such resemblances must be more than superficial, and they must be sought for in other than the common adult forms of animals. 
Fossil Forms. Much light has been thrown on the subject of animal kinships by a study of the animals which have previously lived on the earth. The history of these animals is written in the rocks where their rossil remains are found. From a study of these femains it is generally believed that the first animals existing on the earth were Protozoa. In general, we may say that the older the rocks the simpler are the fossil forms found in them.

Were it not for the evidence furnished by fossils, we should hardly suspect that the first-known horses were
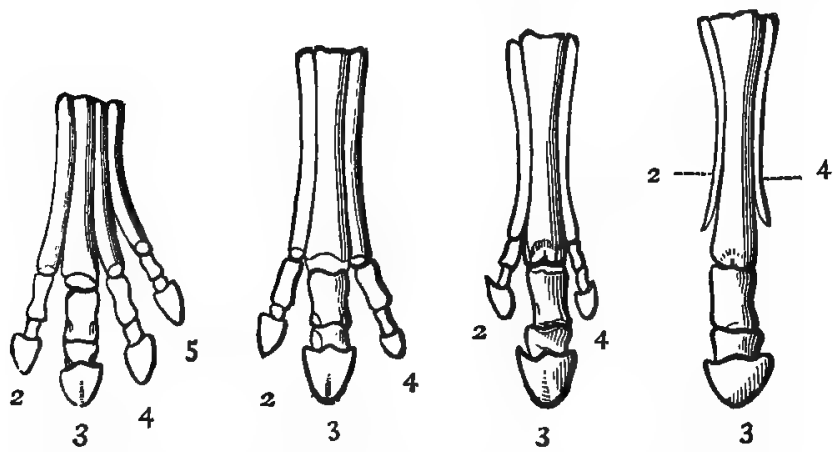

FIG. 197.-Feet of Ancestors of Horse. The figures indicate the numbers of the digits in the five-fingered hand of most mammals.

five-toed animals about the size of foxes. America when discovered had no living horses, yet wild horses are now found in Central and South America. These wild horses are in part the descendants of domestic animals brought to this continent by man; but some are also, doubtless, descendants of animals like those whose remains are found in American rocks.

Among the fossil forms, too, we find the remains of many animals having characteristics shared by widely differing groups of animals of the present day. Such animals are supposed to be the ancestors of the differ- 
ent groups which now repeat some of their most important characteristics. Well-known examples of these forms are the Pterodactyl, a flying reptile, and the archæopteryx, a reptile-like bird.

We do not know that any living birds or reptiles have descended directly from the archæopteryx, but it

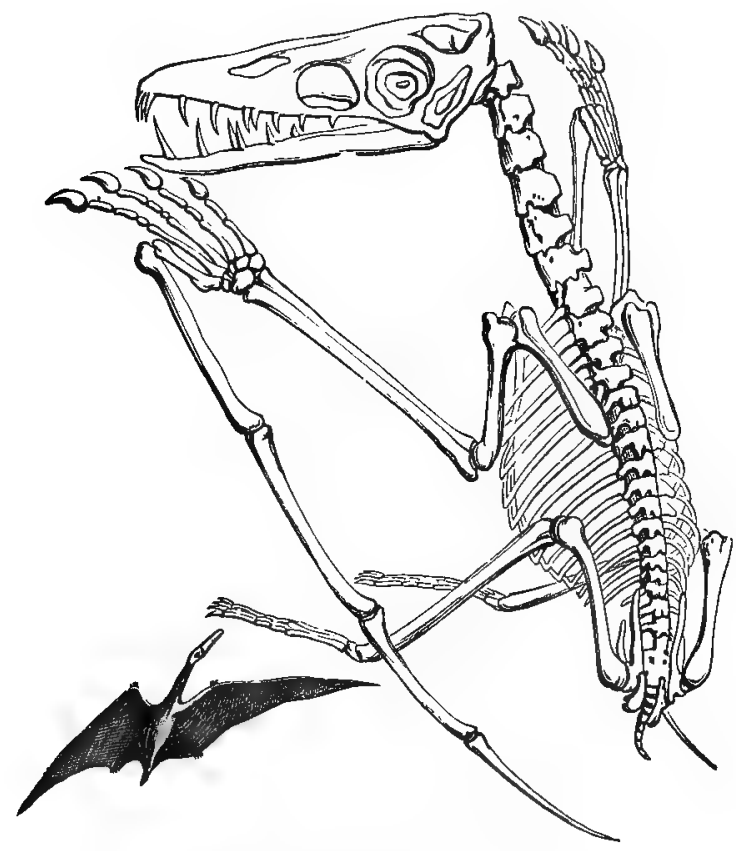

FrG. 198. -A Pterodactyl

certainly seems probable that birds and reptiles are in some manner related by descent. However we may interpret the records in the rocks, it is certain that no accurate classification of animals based on kinship can be made without a careful study of fossils. 
Embryology. The sea-squirts, called also ascidians and tunicates, were once classified as belonging to the Mollusca, and later to the Vermes. Zoölogists now class these animals with the Chordata, because a study of their development shows decided vertebrate characteristics, which disappear with maturity. The larval forms of some of these animals resemble the tadpoles of frogs, showing the notochord and the gill-slits so characteristic of vertebrate animals. Here it is the

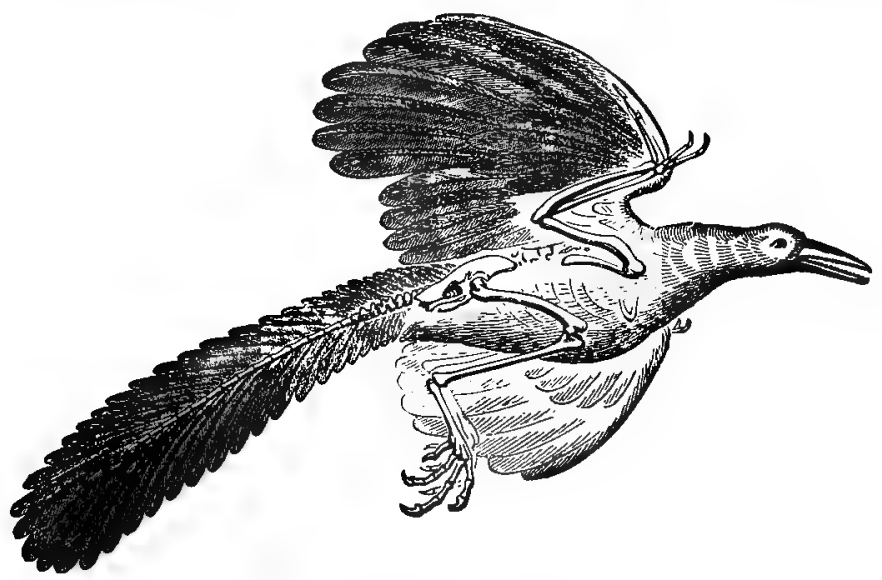

FIG. I 99. - The Archæopteryx.

larval stage alone which shows the true relationship of the animal.

As already pointed out, barnacles and fish-lice do not show in adult life the characteristics which would place them among Crustacea. In many other cases of similar degeneracy the true kinship can be found only by referring to embryonic stages of growth.

Another simple animal classed with the Chordata is the lancelet, or amphioxus, a headless, semi-transparent, boneless creature, which resembles the early 
stages of growth of higher Chordata, and never advances beyond this embryonic condition. These illustrations show us that embryonic conditions must be known in order to classify by relationship.

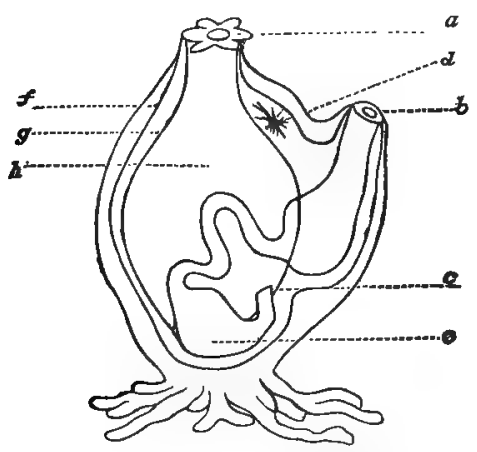

FrG. 200.-Diagram of a Sea-squirt. $\alpha$, mouth; $b$, vent; $c$, gullet.opening; $d$, nerve-ganglion; $e$, stomach; $f$, test or outer layer; $g$, tunic or inner layer; $h$, branchial sac.

In studying the frog, attention was called to the fact that the lungs are formed by simply pushing out the walls of the throat. The air-bladder of a fish, and our own lungs, are formed in the same way. The air-

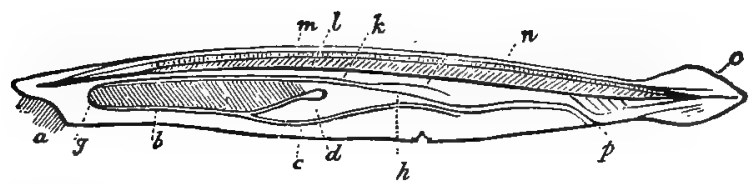

FIG. 201.-Amphioxus. $a$, mouth; $b, c$, heart; $d$, liver; $g$, respiratory organs; $h-p$, digestive canal; $l$, notochord; $m$, spinal marrow; $o$, tail-fin.

bladder of the fish is less complicated than the lung of the frog, and our own lung is more complicated. The process of growth, however, is equally simple in all 
cases, the difference being only in the amount of folding. The liver and pancreas of vertebrates arise in the same way, by folding of the walls of the food-tube.

Other changes take place in as simple a way as this. Indeed, nearly all the organs of a complex body arise by foldings and pushings of layers of cells. When the egg of a very simple animal, like the hydra, develops, it first divides into a number of cells forming a spherical

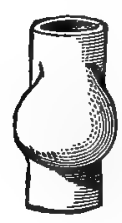

$\mathbf{A}$
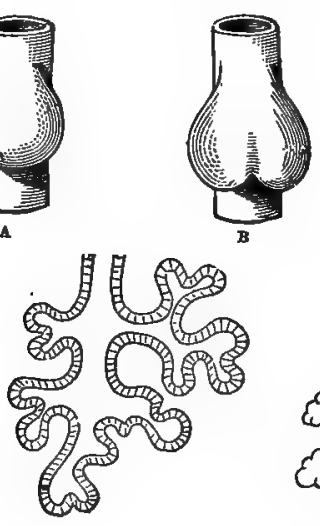

D

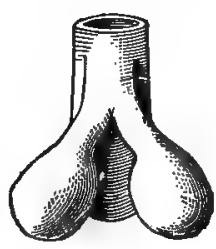

c

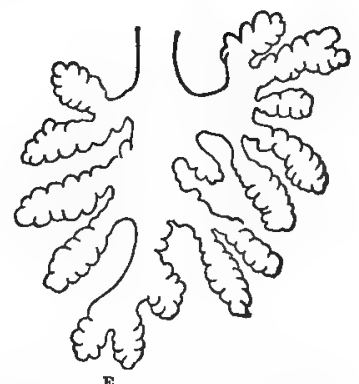

5

FIG. 202.-Growth of Frog's Lung from Primitive Food-tube.

body, the morula stage. One side of this sphere is then pushed in until two layers of cells have been brought near together, the gastrula stage. In animals higher than the hydra a third layer grows between the other two, and from these three layers, by pushings and pullings and foldings, the parts of a complicated animal body arise. These morula and gastrula stages, more or less obscured in many cases, have been found in the development of all the higher animals. The 
fact that such important changes occur so easily during growth leads us to believe that adult forms may undergo modifications by processes as simple as these foldings, if time be allowed for gradual changes through many generations.

We have noted the gradual disappearance of the tail of the tadpole as it reaches maturity. This tail is useful to its possessor for a time, and dwindles away when no longer needed. The tail, and the gills as well, suggest a relationship between frogs and fishes. If we

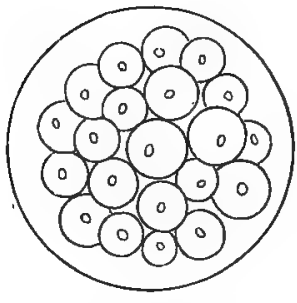

FIG. 203.-Morula Stage.

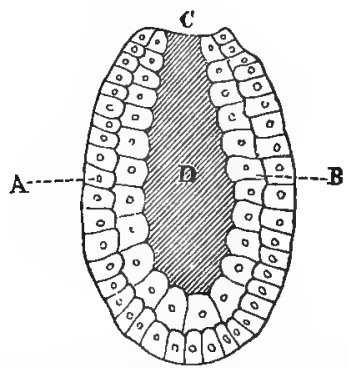

FIG. 204.-Gastrula Stage. $A$, outer layer of cells; $B$, inner layer; $C$, external opening, or mouth; $D$, internal cavity.

examine the embryo of a bird we find, at an early period, a well-formed tail which can be of no possible use to its owner. This tail disappears, as does that of the frog, with further growth. Even more strongly than in the case of the frog is relationship with tailed vertebrates suggested. Naturalists generally believe that this tail is a peculiarity inherited from a reptile-like or fish-like ancestor. Fossil forms like the archæopteryx strengthen this opinion. Many other parts of animal bodies noticed in the process of growth are equally useless to their owners. These are now commonly regarded as inheritances from ancestors to whom these parts were useful. Thus, the possession of gill- 
slits in the embryos of almost all the Chordata suggests a kinship, through inheritance, among the group.

Distribution. We have noted that aquatic insects breathe air by using organs like those of terrestrial insects. From this fact it is commonly inferred that the ancestors of such insects were terrestrial or aerial. Animals which have wandered into a new environment have sometimes so changed their mode of life and their structure as to form a new species differing from the ancestral forms common to the old locality. In cases like these relationships could not be detected by structure alone. Hence the facts of distribution must be reckoned with in determining kinship.

Mimicry and Protective Devices. As we have seen, the real characteristics of an animal may be obscured by the devices it has adopted for its better protection; hence these devices, too, must be considered in connection with relationships.

Heredity. We expect the young of an animal to grow into a form like that of its parent. Every egg of any kind of animal goes through a definite course of development which is essentially like that of every other egg of the same species. Eggs of two different species may develop exactly alike for a time, but they diverge as development goes on. Each egg is true to its kind. This fact of the continual repetition of ancestral traits we call heredity. Experience shows that there are limits to heredity. The young is the product of two parents, and these are not exactly alike. Young animals from the same parents differ in many ways. In any case, however, the differences do not impress us much. With heredity it is the resemblance to ancestors which is the striking fact, and this resemblance is of great assistance in tracing an animal's ancestry.

Variation. Divergences from the regular path of heredity are called variations. For the most part we do not know the causes of variations. That such var- 
iations occur, and that they may be inherited, is certain.

If a florist wishes to obtain a new variety of a certain plant, he watches for variations; and by carefully selecting those plants which vary in the desired manner, he is able, after several generations, to produce what he wishes.

As we have previously pointed out, variations which help an animal to maintain its place against enemies, and in the face of obstacles, are the ones likely to be transmitted to offspring, and so perpetuated. Natural selection, which depends on both heredity and variation, must be considered in determining the relationship of animals.

A Genealogical Tree. To show relationships, resort is often had to devices known as genealogical trees. These are supposed to show the ancestry of animals. As so many facts must be known to determine ancestry, such schemes must always be considered as only attempts to show relationships in a very general manner. Greater knowledge may at any time compel changes to be made.

Classification. A scheme of classification should tell the same story of kinship as the genealogical tree. It must also be subject to change, for the same reasons as the tree. At present there is no classification of animals acceptable to all the persons qualified to judge of such matters. What follows is a somewhat provisional extension of the outline presented in Chapter I. 


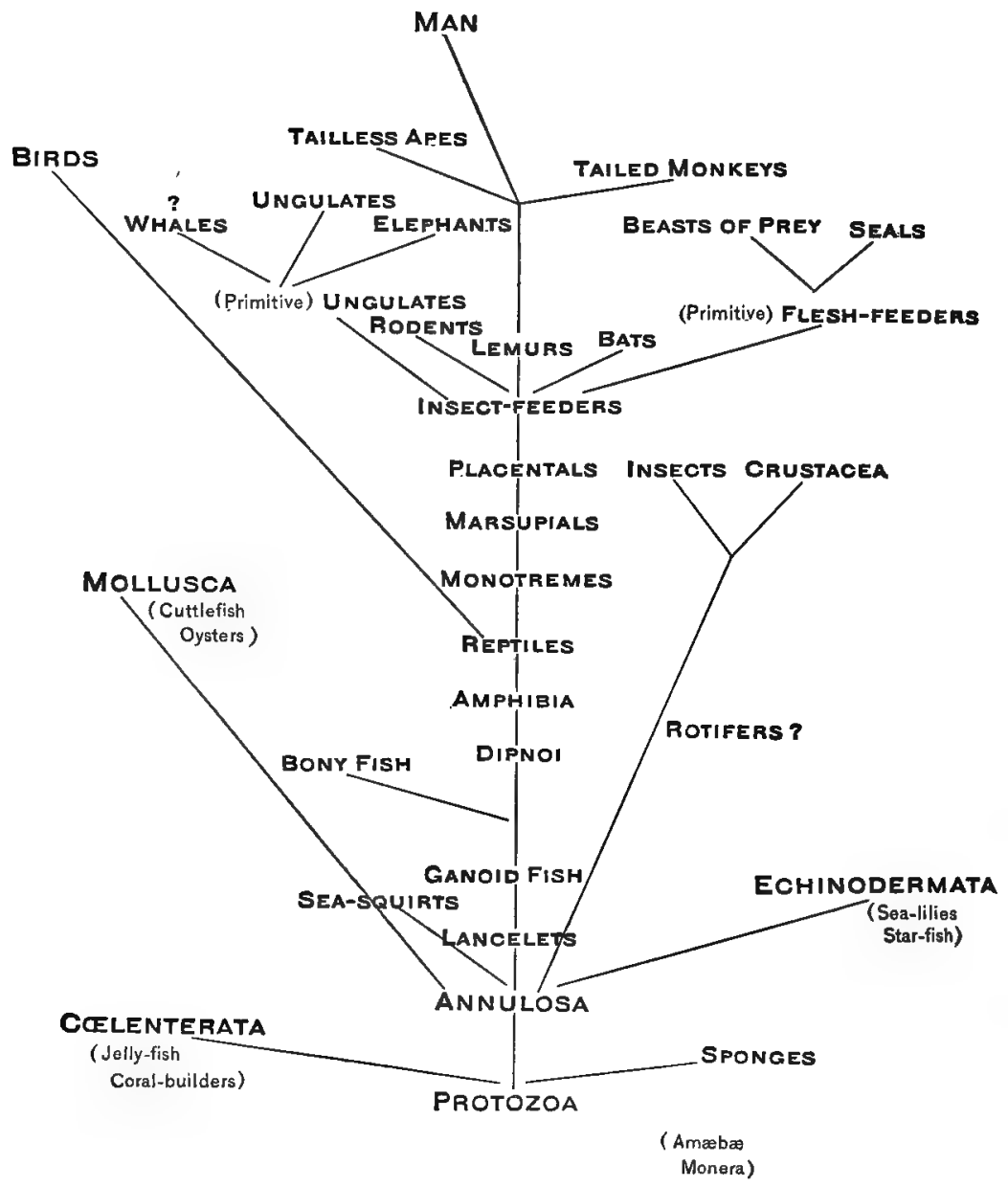

FIG. 205.-A Genealogical Tree. 
PROTOZOA. $\quad\left\{\begin{array}{l}\text { CLASSEs. } \\ \text { Rhizopoda move by pseudopodia. Examples of } \\ \text { this class are amoeba and chalk-animals. } \\ \text { Infusoria move by cilia. Examples of this class } \\ \text { are the bell animalcules and paramecium. There } \\ \text { are other classes of Protozoa. }\end{array}\right.$

Keratose sponges have skeletons made of horn-like material.

Calcareous sponges have skeletons composed of spicules of carbonate of lime.

PORIFERA. Silicious sponges have skeletons composed of quartz-like material, or of a combination of silicious spicules and silk-like fibres.

These groups are not strictly classes. All iponges belong to the class Porifera.

CLASSES.

Hydrozoa have the mouth at the top of a sort of proboscis. The entire body-cavity is a digestive cavity. Hydra, hydractinia, campanularia, sertularia, and many kinds of jelly-fish belong to this class.

CELLENTERATA.

Scyphozoa are marine jelly-fishes.

Actinozoa have the mouth-opening into a stomach-cavity distinct from the body-cavity. The body is also divided by radiating partitions. Sea-anemones and coral animals belong to this class.

Ctenophora are transparent or nearly transparent comb-jellies.

CLASSES.

Asteroidea are animals resembling the common starfish.

Ophiuroidea are animals resembling the sand-stars.

Echinoidea are animals resembling seaurchins.

Crinoidea are stemmed forms. As fossils they occur in great abundance. They are known as stone-lilies.

Other classes of Echinodermata are largely fossil forms.

ECHINODERMATA.

No attempt is here made to give classes of Vermes. Instead of Vermes many authors now name several subkingdoms or phyla. Some of these are as follows:

Platyhelminthes, or Flatworms. These are worms of low organization, including parasites like the liver-

VERMES. fluke and tapeworm.

Nemathelminthes, Roundworms. These low forms have cylindrical bodies. The trichina belongs here. Rotifers, Polyzoa, and Brachiopoda have been variously classed, often as members of the sub-kingdom Vermes. Theír position is not fully settled. 
VERMES. $\quad$ Annulata. These are the more highly organized worms like the earthworms and leeches. They are commonly regarded as a separate sub-kingdom or phylum.

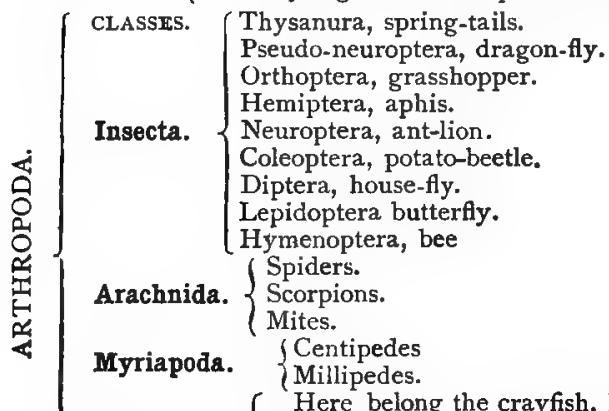

Crustacea. $\left\{\begin{array}{l}\text { Here belong the crayfish, lobster, shrimp, crab, } \\ \text { sand-hopper, pill-bug, asellus, cyclops, daphnia, } \\ \text { fish-lice, barnacles, and many other arthropoda } \\ \text { which breathe by means of gills. }\end{array}\right.$ $\left\{\begin{array}{l}\text { CLASSES. } \\ \text { Pelecypoda, or bivalve mollusks, like clams, oysters, } \\ \text { and scallops. }\end{array}\right.$ MOLLUSCA. Gastropoda, or univalve mollusks, like slugs and snails. Cephalopoda, including the squid, octopus, and nautiJus.

Amphineura, including the chitons.

Omitting some low forms of somewhat doubtful relationship, we may call all animals belonging to this sub-kingdom Vertebrata and include them in classes as given below.

CLASSES.

CHORDATA. Cyclostomi, including the lancelet or Amphioxus.

Pisces, including all fishes.

Amphibia, including frogs and their allies.

Reptilia, including snakes and turtles.

Aves, including birds.

Mammalia, including the higher animals bearing hair or fur and provided with glands secreting milk. Man belongs to this class and to the order Primates, to which order the monkeys also belong.

\section{VOCABULARY.}

Am phi ox'us (Gr. amphi, on both sides), and oxys, sharp), a small fish-like vertebrate. It is also called the lancelet.

An nu la'ta (Lat. annulus, a little ring), a division of Vermes including the common earth-worm.
Archæ op'te ryx (Gr. archaios, ancient, and pteryx, a wing), a fossil bird.

A'ves (Lat. avis, a bird), birds.

Di'a phragm (Gr. dia, through, and phragnymi, to enclosel, a muscle characteristic of mam- 
mals, separating the thoracic and visceral cavities.

Dig'i ti grade (Lat. digitus, a finger, and gradus, a step). walking on the toes without using the sole of the foot.

Gas'tru la (Lat. dim. of gaster, the belly), an embryonic form of animals belonging to the Meta. zoa.

Mam'mal (Lat. manıma, breast), a vertebrate animal whose female has milk-producing glands.

Mor'u la (Gr. moron, a mulberry), an early stage from the growth of an egg.

Plan'ti grade (Lat. planta, the sole of the foot, and gradus, a step), applied to animals which walk on the sole of the foot.

Pter o dac'tyl (Gr. pleron, a wing, and dakiylos, a finger), an extinct flying reptile. 



\section{INDEX.}

\section{A}

Abdomen of crustacea, IO2

$$
\text { "، " } \text { " insects, } 32
$$

Aboral surface, I40

Acephala, I65

Actinozoa, 137

Activities of amoba, II6

$$
\begin{aligned}
& \text { " " bird, I99 } \\
& \text { " " butterfly, } 47 \\
& \text { " " earthworm, I50 } \\
& \text { “ " fresh-water mussel, } \\
& 158 \\
& \text { " "frog, } 181 \\
& \text { " " "grasshopper, } 36 \\
& \text { " " hydra, I29 } \\
& \text { " " spider, } 93 \\
& \text { " " starfish, I42 }
\end{aligned}
$$

Adaptations, 86

Adductor muscles, I56, I59

Air-sacs of birds, 205

$$
\text { " " spiders, } 97
$$

Alimentary canal, 37

Alternation of generations, 133

Ambulacral areas, $14 \pi$

Amœba, I 16

$$
\text { feet, } 140
$$

Amphibia, I92

Amphioxus, 247

Ampullæ, I4I, I43

Analogous organs, Io6

Anatomy, 30

Angleworm, 148

Animal kingdom, 2

Animal relationships, 243

Annulata, 148

Anodon, 155, 157, 254

Anosia plexippus, 68

Antennæ, 33

$$
\begin{aligned}
& \text { "6 of crayfish, } 105 \\
& \text { (6 " grasshoppers, } 33
\end{aligned}
$$

Antennules, ro5

Aorta of fish, I7o

" "frog, I95

Ápes, 232

Aphis, 72

Apparatus, 4

Appendicular skeleton of frog, I89

Aquaria, 8

Arachnida, II3

Archæopteryx, 209

Argonaut, I66

Aristotle's lantern, I46

Arthropoda, 2, I I I

Ascidians, 246

Asellus, 86

Assimilation, 1 I8

Asterias vulgaris, I40

Atlas bone, 188

Auditory nerves, 173

Auricle of fish, I70

Aves, 254

Axial skeleton, 220

، " 6 of frog, 188

B

Balancer of fly, $5^{8,67}$

Barnacles, Iro

Barriers, 238

Basipodite, IO4, IO7

Bat, 222

Batrachia, I92

Bees, 89, 90

Bilateral symmetry, 32

Biology, 25

Birds and insects, 200

" " reptiles, 205

Blood-corpuscles, I84

Blue-bottle fly, 57

Bluejay, 23

Bones of fish, I73 " " frog, 188 
Botany, 3 I

Branchial arches of fish, $\mathbf{I} 70$

Bream, I4

Breeding-cage, 6

Brittle starfish, 144

Butterflies, 5, 2I, 45

Butterfly enemies, 50

Byssus, 167

\section{C}

Cabbage-butterfly, 49

Caddis-fly and larva, 79

Calcareous sponges, I25

Campanularian hydroids, I4

Carapace, 104

Carbon, 28

Carbon dioxid, 28

Care of specimens, 17

Care of young among birds, 202

Carpus, 194, 204, 2 ro

Case insects, 12

Cat, $21 \mathrm{I}$

Caterpillars, 6, 48

Catfish, I4

Catocala, 52

Causes of dispersals, 238

Cecropia, 22

Cell, 117

Centipede, 98, 99

Cephalopoda, 166

Cephalothorax, ror

Cerebellum, 173

Cerebral lobes, I73

Cerebrum, 173

Chalk animals, I20

Characteristics of actinozoa, 137

$\begin{array}{ll}\text { " " } & \text { " amphibia, I92 } \\ \text { " } & \text { "6 birds, 205 } \\ \text { " } & \text { " colenterata, I37 } \\ \text { "6 } & \text { " crustacea, I I3 } \\ \text { " } & \text { " echinodermata } \\ \text { " } & \text { " hydrozoa, I47 } \\ \text { " mollusca, I66 } \\ \text { " } & \text { " pisces, I75 } \\ \text { " protozoa, I23 } & \text { " reptilia, I92 } \\ \text { " } & \text { " scyphozoa, 137 }\end{array}$

Chemistry of life, 24

Chimpanzee, 182

Chitin, 44
Chordata, 2, 174, 254

Chrysalids, 48

Cilia, I2I

Circulation of birds, 201

$$
\begin{array}{lll}
" \text { " fish, I7I } \\
\text { " } & \text { "frog, 185 } \\
&
\end{array}
$$

Classes, II2

Classification of animal kingdom, $2,243,253,254$ 255

" arthropoda, II I

" birds, 207

" insecta, 64

" mammalia, 224

Clavicle, 194

Clitellum, 149, 15 I

Cloaca, $20 \mathrm{I}$

Cockroach, 20, 86

Cocoons, 48

Colenterata, 2, 128, 129, 137, 253

Coleoptera, 65

Collecting, 4

Colonies, I4, I32

Colorado beetle, 6o, 238

Columbinæ, 208

Commenselism, $\mathbf{r} 32$

Common crab, 2, 108

Compound eye, $4 \mathrm{I}$

Compounds, 27

Condyle, I88, 210, 21 7, 2 I9

Contractile vacuole, II7

Coracoid bones, 203

Coral, 2, I 35

Cornea, 214

Corpuscles, 184

Costal, 56

Coxa of insects, 34

Coxopodite, IO4, IO7

Crayfish, 2, 13, Ior

Cricket, 5, 4I, 42

Crinoids, 146

Cross-fertilization, I3I

Crow, 23

Crustacea, ror

Ctenophora, 253

Cyclops, II, IO9

D

Danais archippus, 68

Daphnia pulex, Iog 
Decomposition of water, 26

Definitions: see vocabularies

Degeneration, I IO

Dental formulæ, 2I2

Derivations: see vocabularies

Diaphragm, 223

Differentiation, I3I

Digestion, 128

Digitigrade feet, 228

Diptera, 64

Discovery', 30

Dispersals, 237

Dissection of grasshopper, 34

Distribution of animals, 236, 250

Ditycus, 80, 87

Division of labor, I3I $^{1}$

Dragon-fly, 60, 76

Duckweed, 9

\section{E}

Earthworm, 7, 148

Echinodermata, 142

Ectoderm, 123

Eggs of birds, 201 "6 " frogs, 23, I88

Elements, 27

Elytra, 67

Embryology, 246

Enamel, 23I

Endoderm, 123

Endopodite, I04, I07

English sparrow, 197

Entomostraca, Io9

Epidermis of mammals, 229

Eustachian tube of frog, I8r

Excretion, 30

Exopodite, 104, I07

Experiments, 25

\section{F}

Facets, 33

Families, 112

Fauna, 237

Feathers, 198

Feet of birds, 198

Femur of insects, 34

$$
\text { " " man, } 194
$$

Fertilization of plants by insects, 89 Fibula, 167
Fingers and toes of inammals, 224

Fins of fish, 159

Fishes, 169

Fission, 118

Flies, 6, 57

Flight of birds, 202, 203, 204

$$
\text { " " insects, } 42
$$

Food of amœba, i 8

$$
\begin{aligned}
& \text { " "butterfly, 5, } 49 \\
& \text { " " caterpillar, 6, } 48 \\
& \text { " " crayfish, I3 } \\
& \text { " " earthworm, I50 } \\
& \text { " "fish, I69 } \\
& \text { " "fly, 6, } 57 \\
& \text { " “ frog, } 7,179 \\
& \text { "6 " grasshopper, } 3^{6} \\
& \text { " "hydra, II, 128, } 129 \\
& \text { " "leech, I? } \\
& \text { “" " mussel, 8, I66 } \\
& \text { “" " slug, } 7 \\
& \text { " " snail, } 8 \\
& \text { “" "s spider, 6, } 94 \\
& \text { “" " starfish, I } 42 \\
& \text { “ " tadpole, I3 } \\
& \text { “" "turtle, } 7 \\
& \text { "6 " wasp, } 5
\end{aligned}
$$

Foot of horse, 228

Foraminifera, 120

Formaldehyde, I9

Fossils, 244

Fresh-water mussel, I55

Frog, 7, 179

Frogs' eggs 23, 186

Fungi, d, I36

\section{G}

Galaxea, 136

Ganglion, 36

Gastropoda, 165

Gastrula, 249

Genealogical tree, 252

Genera, II2

Geological distribution, 237, 241

Gill arches, I7o

" clefts, I70

“ filaments, r 70

“ slits, 170

Gorilla, 220

Grallatores, 208

Grasshopper, 5, 32

Growth of lungs in frogs, 187 
H

Habitat, 236, 240

Habits and organs, 88

Hæmal arch, r74

Hair, 229

$$
\text { " cavity, } 174
$$

Hands and feet of mammals, 227

Haustellate, 56

Head of insect, 33

Heart of frog, 183

Hemiptera, 65

Heredity, 250

Hermaphrodite, I3I

Hermit-crab, I8

Hinge ligament, 162

Histology, 3I

Homologies, 107

Homologous organs, ro6

Hoofs, 230

Horns, 230

Hornwort, 9

House-fly, 5

Humerus of frog, 189

Hydra, Io, 128

Hydractina, I3I

Hydrozoa, 137

Hymenoptera, 66

I

Ichneumon-fly, 74

lmago, 49

Incisors, 212

Infusoria, 121

Inhalent pores of sponge, I24

Insect adaptations, 86 " communities, 89

Insects and plants, 9I

Interambulacral areas, I4I

Isolated areas, 239

$$
\text { plates, I4I }
$$

\section{$\mathrm{J}$}

Jelly-fish, I54, 155

$\mathrm{K}$

Kallima, 6r

Keel in birds, 205

Keratose sponges, 125
L

Labium, 33

Labrum, 33

Lamellibranchiata, 165

Lancelet, 247

Larvæ of butterflies, 48

Lateral line, 169

Leech, I3

Lepidoptera, 45, 46

Life, 24

Life-histories, 68

Limenitis ursula, 53

Lingual ribbon, 166

Lithobius, 98

Living matter, 24

Lobster, 102

Locust, 32

\section{M}

Madrepora, 136

Madreporic body, 140

Mammals, 217

Mammalian skeleton, 218

"6 viscera, 223

Mandibles, 33

Mantle of mollusca, 156, 161, I66

Mask of dragon-fly larva, 77

Materials for study, 4

Matter, 24

Maxillæ, 34

Maxillipeds, ro3

May-fiies, 80

Medulla oblongata, 195

Medusa, 134, 135

Mesenteries of sea-anemone, I35

Mesogloa, 123

Metamorphosis of insects, 47

Microgaster-fly, 75

Migration, 238

Milkweed-butterfly, 68, 237

Mimicry, 53, 250

Mollusca, 2, 165, 166

Morula, 249

Muths, 45

Moulting, 39

Mouth-parts of insects, $33,34,35$

Mud-wasp, $6 r$

Muscles of frog, 188

Mussels, 8, 155 


\section{N}

Names of insects, 66

Natatores, 208

Natural selection, 54

Nauplius, I I I

Nautilus, 166

Nemathelminthes, 253

Neuroptera, $\sigma_{5}$

Nettling cells, 129

Neural arch, 173

" cavity, 174

"s spine, 174

Nictitating membrane, 197

Nitrogen, 27

Notochord, 177

Nucleus, II 7

Nutrition, 30

" of grasshopper, 37

$\mathrm{O}$

Ocelli, 33

Olfactory lobes of fish, $\mathbf{1 7 3}$

Orsperms, I3I

Operculum of snail, 164

Optic lobes of fish, 173

Oral surface of starfish, $14^{\circ}$

Orders, II 2

" of insects, 64

Orthoptera, 65

Oscula of sponge, 124

Osmosis, $3^{8}$

Ovipositor, 33

Oxidation, 27

\section{$\mathbf{P}$}

Pallial line, 156

Palpi, 34

Paramecium, r22

Parthenogenesis, 73

Passeres, 208

Pearls, I6I

Pectoral fins, 169

Pectoral girdle, I75

Pedal ganglia, I62

Pedicellariæe, I4O

Pelecypoda, 165

Pelvic girdle, 175

Peritoneum, 18r

Phalanges, 189, 199

Phosphorescence, 114
Phylum, I, 2

Physiology, 3o

Pisces, 175

Plantigrade feet, 227

Plant-lice: see Aphis

Pleurum, 32

Poison-fangs of spiders, 97

Polyp, 135

Polyzoa, 253

Pond-snail, 163

Pond-weed, 9

Porifera, 125, 254

Preparation of specimens, 17

Preservation of specimens, I9

Primates, 254

Proboscis of moth, 5o

Prolegs, 69

Protection of birds, 200

Protective coloring, 52

Protopodite, 104, 107

Protozoa, II6, I23

Pseudoneuroptera, 65

Pseudopodia, I I9

Pterodactyl, 245

Pupation, 70

\section{$\mathbf{R}$}

Radiate symmetry, 2

Range of animals, 237

Raptores, 208

Reference-books, vi

Repair, 26

Reproduction, 30

Reptilia, I92

of amœba, II 8

" grasshopper, 37

Resemblances, 6I, II I

Respiration of grasshopper, 37

Rhizopoda, x I 9

$\mathrm{S}$

Sand-wasp. 74

Sarcoda, I23

Sauropsida, 207

Scansores, 208

Scyphozoa, r34, 137

Sea-anemone, I5

" cucumber, I46

" squirt, 246

" urchin, 145

Sedentary, I I5 
Senses of grasshopper, 40

Septa of coral, 135

Serial homology, IO7

Shrimp, Ior

Silicious sponge, 125

Siphon of mussel, I 58

Skeleton of bat, 222

$$
\begin{aligned}
& \text { " "bird, I93 } \\
& \text { " " chimpanzee, } 223 \\
& \text { " " fish, } 173 \\
& \text { " " frog, I93 } \\
& \text { " " horse, } 215 \\
& \text { " " man, } 194
\end{aligned}
$$

Slugs, 7, 162

Smelt, 169

Snails, 5,163

Snakes, 7

Somite, 104

Sow-bug, 5

Species, 112

Sperms of hydra, I3o

Spicules of sponge, 125

Spider, 93

Spinal cord, 173, 174, 195

Spinal nerve, 173

Spinnerets, 94

Spiracles, 32

Sponges, 123

Squash-bug, 6I

Squid, 166

Starfish, 140

Sternum, IO4

Stone-lilies, 2

Stridulating, 4I, 42

Structure and habitat, 240

Struthii, 207

Stylets, 43

Supracesophageal ganglia, 167

Survival of fittest, 35

Swimmerets, 103

Sympathetic system of nerves, I8I Synapta, $\mathbf{1 4}_{4} 6$

\section{$\mathrm{T}$}

Tadpoles, $\mathbf{I 7 9}$

Tanning worms, $\mathrm{I}_{4} 8$

Tarsus of insect, 34

" " man, I97

Teeth of mammals, $23 \mathrm{I}$

Telson, 115

Tergum, 32, 104
Thecæ, 138

Thorax of insects, 33

Thysaneura, 65

'Tibia of insect, 34

$$
\text { " "man, I94 }
$$

Tongue of frog, 182

Trachea of an insect, 38

Trochanter of insects, 34

Turtles, 7

Tympanum, 33

\section{$\mathrm{U}$}

Unio, 155

Urostyle, 198

Urea, 29

Usefulness of earthworms, 153

$$
\text { V }
$$

Variation, 25I

Ventricle of fish, r 70

Vermes, 148

Vertebrata, 174, 254

Visceral cavity, 174

Vocabularies of terms applied to one-celled animals and sponges, I26

colenterata, 147

crustacea, II 5

echinodermata, 147

insects, 44, 56, 67, 85

mollusca, 167

vertebrate animals, 176, 177, 2 IO, 255

Vocabularies of general terms frequently used, 3I, 100, 255

\section{W}

Wasps, 5

Waste, 26

Water-boatman, 8o, 8I

" fleas, I09

" spider, 95

Web of spider, 95

Wing of birds, 198

"6 " insect, 42

Winglet, $5^{8}$

\section{Z}

Zooids, 132

Zoology, $3^{\circ}$ 





